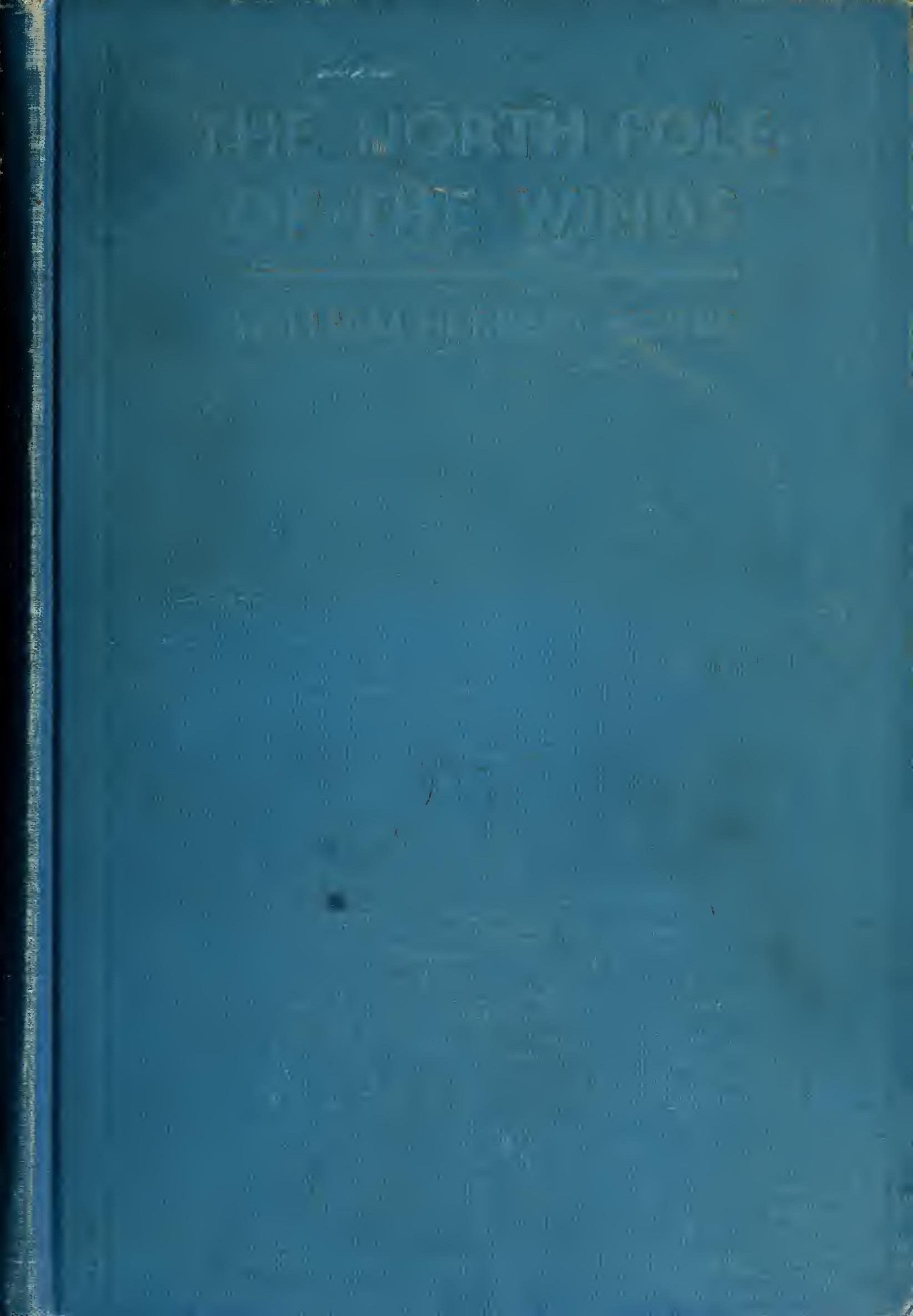




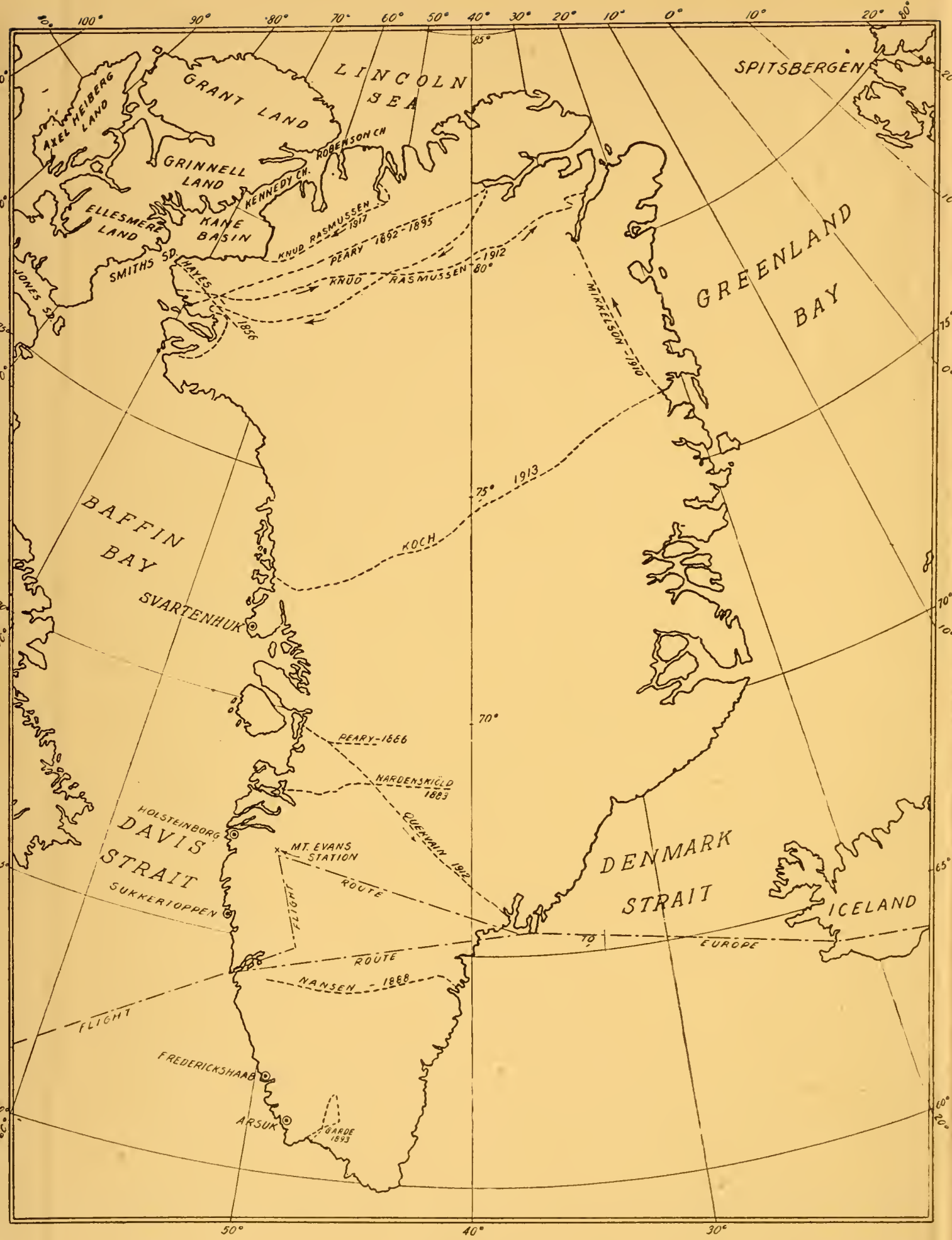




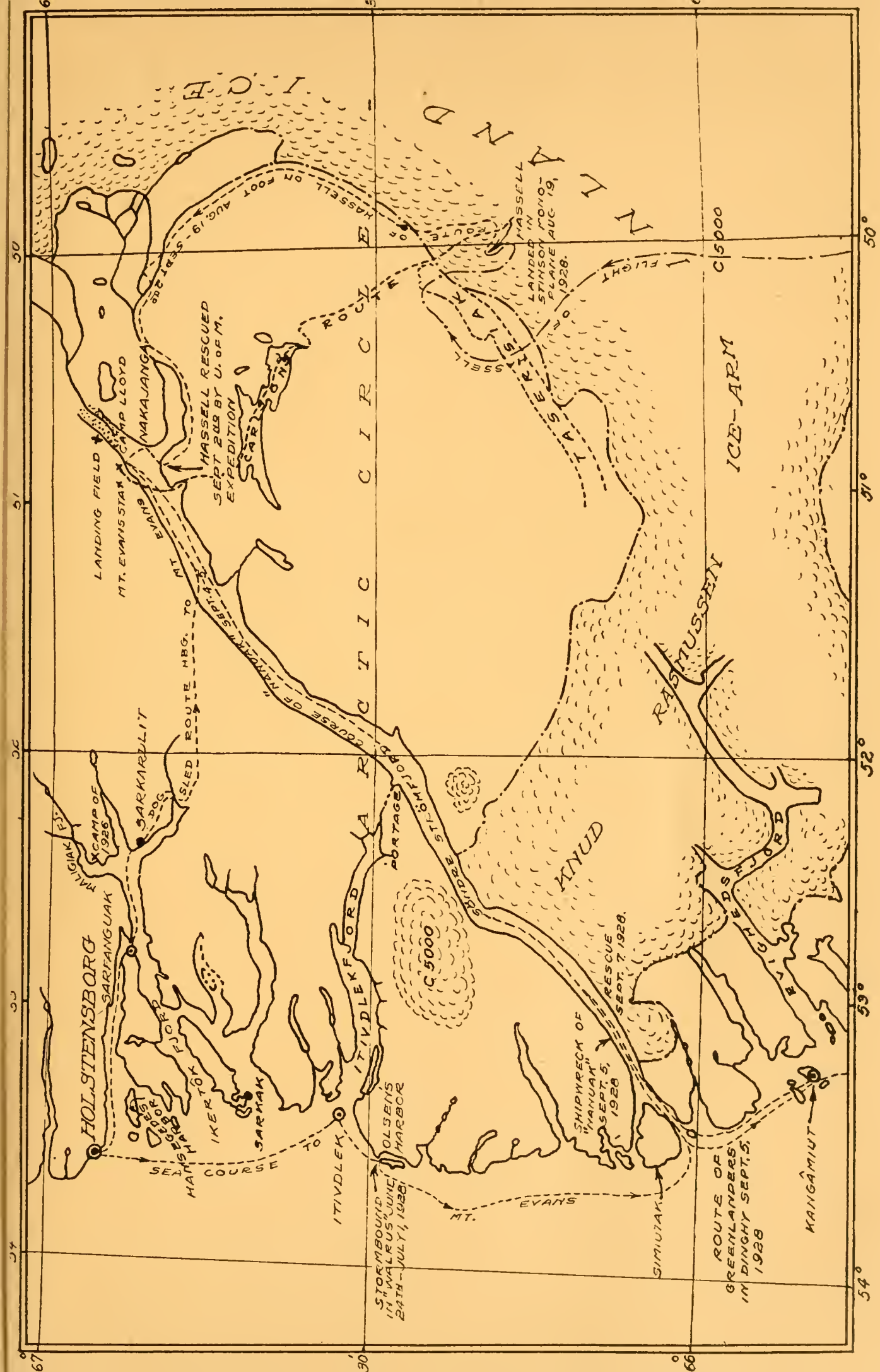








\section{BOOKS BY WILLIAM HERBERT HOBBS}

Earthquakes, an Introduction to Seismic Geology -Appleton

Characteristics of Existing Glaciers-Macmillan

Farth Features and Their Meaning-Macmillan

The World War and Its Consequences, with an Introduction by Theodore Roosevelt-Putnam

Leonard Wood, Administrator, Soldier and Citizen, With AN Introdection by Henry A. Wise WoodPutnam

Earth Evolution and Its Facial Expression-Macmillan

Cruises Along By-Ways of the Pacific-Stratford

The Glacial Anticyclones, the Poles of the Atmospheric Circulation-University of Michigan

Exploring About the North Pole of the Winds -Putnam 


\section{EXPLORING ABOUT THE NORTH POLE OF THE IVINDS}




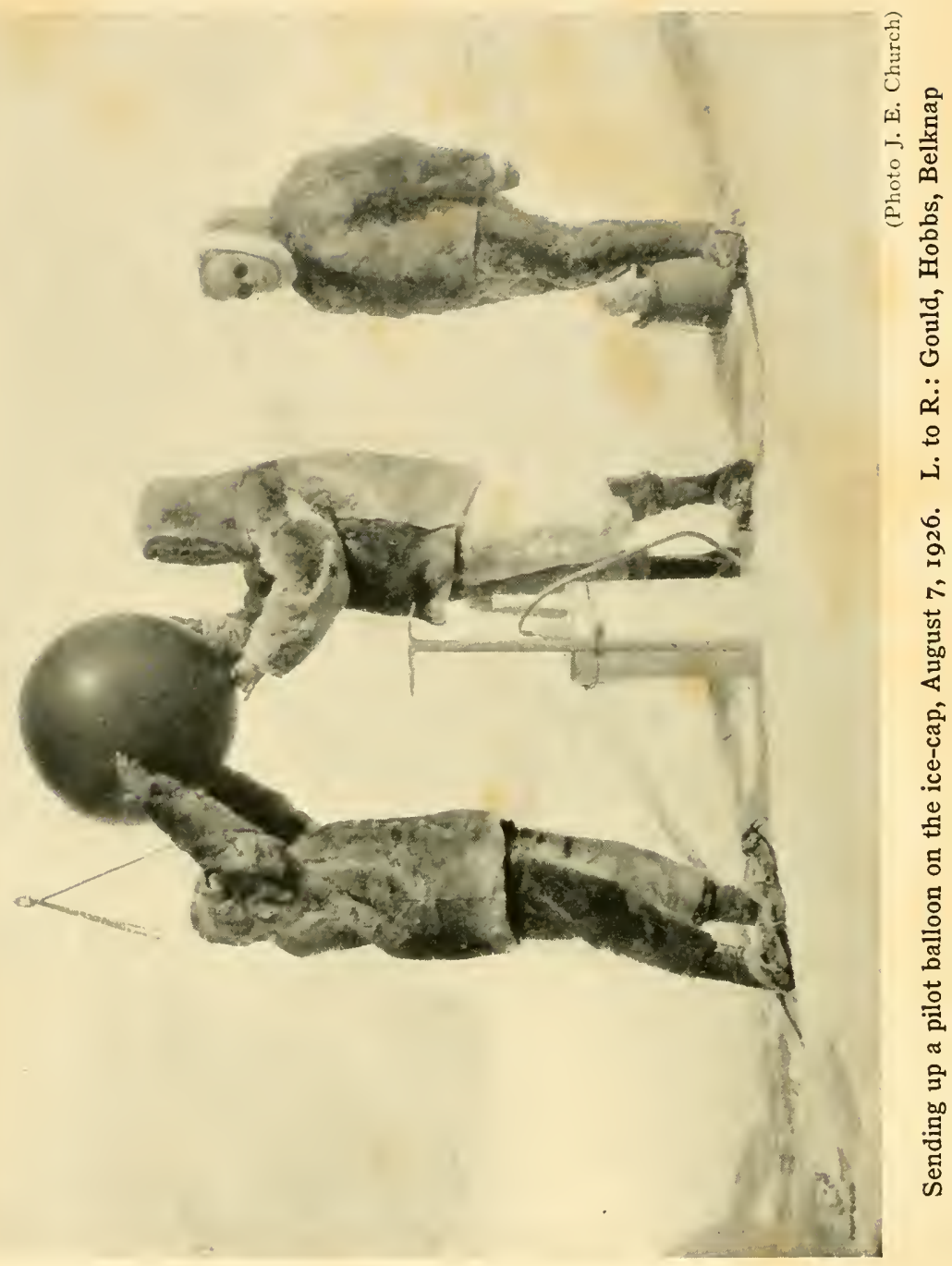




\title{
Exploring About the North Pole of the Winds
}

\author{
by \\ WILLIAM HERBERT HOBBS \\ Professor of Geology and Director of the Greenland \\ Expeditions of the University of Michigan
}

Decorations by the Author

WITH 26 ILLUSTRATIONS AND MAPS

NEW YoRk G. P. PUTNAM'S SONS LONDON

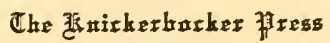
1930 
EXPLORING ABOUT THE

NORTH POLE OF THE WINDS

\section{Copyright, r 930}

by

G. P. Putnam's Sons

Published, Winter, I930

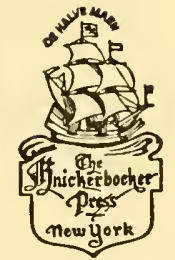

Made in the United States of America 


\section{CONTENTS}

CHAPTER

PAGE

I.-The First Cruise to Greenland on the Morrissey . . . . . . . . 3

II.-IN Camp on the Maligiakfjord • . 17

III.-The Motor-Canoe Swamped and The Rescue . . . . . . $\quad$. 30

IV.-The Winds From the "Great Ice" . 39

V.-Exploring the Upper Air . . . 48

VI.-The Summer Expedition to the Ice-Cap 60

VII.-The Return on Forced Marches . . 76

VIII.-Again in Camp on the Maligiakfjord • 87

IX.-The Stormy Return Cruise on the Crip-

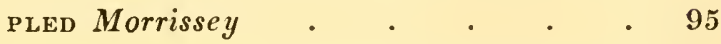

X.-The Second Expedition to Greenland on THE Disko . . . . . . . . 108

XI.-Storm-Bound on the Walrus . . . 114

XiI.-Bullding the Expedition Base on Mount Evans . . . . . . . 128

XIII.-REConnaissancE . . . . . 146

XIV.-The Second Expedition to the Ice-Cap 154

XV.-On the Ice-Cap and Back to Camp Lloyd 170 


\section{CONTENTS}

CHAPTER

PAGE

XVI.-Bangsted's Winter Expedition to the

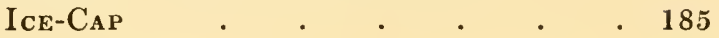

XVII.-The Third Greenland Expedition . . 203

XVIII.-The Relief of Carlson at Mount Evans 212

XIX.-Preparing for the Rockford Flyers . 220

XX.-Exploring in the Caribou Country 237

XXI.-The Search for Hassell and Cramer - 254

XXII.-The Rescue . . . . . . 265

XXIII.-SHIPWRECKED . . . . . . . . 283

XXIV.-In Peril of Waters off the Greenland

CoAst . . . . . . . . . 299

XXV.-Aboard the Tramp-Ship Fulton • 312

XXVI.-Carlon's Winter Dog-Sled Expedition 328

XXVII.-Our Wireless Station's Activities 343

XXVIII.-The Closing of the Station . . . 357

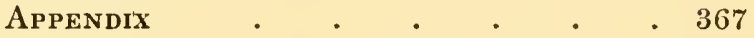

INDEX $\quad . \quad$ • $\quad . \quad$. $\quad 373$ 


\section{ILLUSTRATIONS}

PAGE

Sending up a Pilot Balloon on the Ice-cap

Frontispiece

The First Expedition Aboard the Morrissey . 9

Vifw Looking Down Upon University Bay . . 23

The Motor-canoe in which Gould and Belknap so

Nearly Lost their Lives $\quad . \quad$. . . . 35

Following a Balloon at Camp on the Maligiakfjord 51

Sounding Balloon Work

The Trek Across the Tundra . . . . . . . 71

Otto Nordenskjöld Glacier Tongue $\quad$ • $\quad$ - 77

EXPEDITION OF 1927 on the Walrus . . . . 115

Mount Evans Aerological Station . . . . 139

Following a Balloon at Mount Evans . . . 143

Lower Chute of the Kelsey Cataract . . . 149

Upper: Ice-cliff at Edge of Inland-ice. Lower: A

CAMP on the InLAND-ICE . . . . . . 175

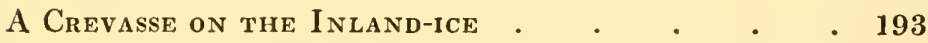

Upper: The "White Mountains." Lower: Dogsled

Party on the Frozen Fjord . . . . 199

The Airplane Landing Field Near Mount Evans . 233 vii 


\section{ILLUSTRATIONS}

KITE WAGE

The Rescued Fliers and their Rescuers • • . 273

After the Shipwreck of the Nakuak $\quad . \quad$. 289

Camp Near Mouth of Söndre Strömfjord • . 295

Arrival of the Rescue-ship Nipisak . . . . . 303

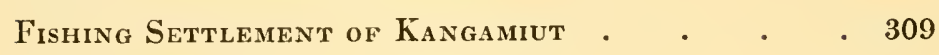

The Fulton at the Dock of Ivigtut . $\quad . \quad \ldots \quad$. 317

The Radio Transmiter at Mount Evans • • 345 
EXPLORING ABOU'T THE NORTH POLE OF THE WINDS 



\section{EXPLORING ABOUT THE NORTH POLE OF THE WINDS}

\section{CHAPTER I}

THE FIRST CRUISE TO GREENLAND ON THE MORRISSEY

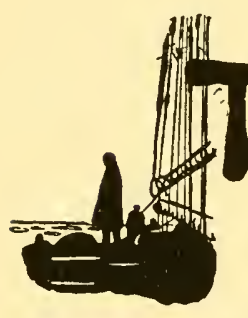

HE motor-schooner Morrissey, Captain "Bob" Bartlett, master, on the morning of June 27, 1926, swung at her moorings in the harbor of North Sydney, Nova Scotia. On board were the personnels of two expeditions about to sail for the Arctic and the stores for three expeditions. Every foot of cargo space was taken and the decks were hidden under piles of lumber, nests of dories, gasoline drums, canoes, etc., all well lashed and made snug for possible nasty weather. 
The Morrissey is of 83 tons register, 100 feet Iong, and with the lines of a yacht. A report had come to North Sydney that the straits of Belle Isle, which separate Newfoundland from Labrador and through which the Morrissey was to sail, were still crammed solid with field ice pushed in from Davis Strait. However, a favorable southerly wind might clear the straits at any time, and under an overcast sky the anchor was weighed and at eleven o'clock under full sail and with motor running we moved out to sea.

The Morrissey had been chartered for the expedition of the American Museum of Natural History under command of George Palmer Putnam and was setting out to cruise in Baffin Bay and secure specimens of the larger forms of ocean life for the new Oceanic Hall of the Museum. The other members of this expedition were: Dr. Harry C. Raven of the Zoological Staff of the Museum and second-in-command of the expedition; Daniel W. Streeter of Buffalo, hunter; "Art" Young, champion bowman of the world and famous for his killing with bow and arrow of big game animals in Africa and Alaska; Carl Dunrud, cowboy roping expert who captures big game with the lariat. To prepare the skins Fred Limekiller of the Museum staff was included. Maurice Kellerman, mo- 
tion picture expert of the Pathé Corporation, who had already made pictures for other expeditions, was of the party, and Dr. Peter Heinbecker, wellknown specialist, had shipped as surgeon and was interested especially in the pathology of the Greenland Eskimos. The engineer of the expedition was Robert E. Peary, Jr., son of the discoverer of the North Pole, with Young and Dunrud as assistants, and Edward Manley was radio operator. Mr. Putnam was taking with him his thirteenyear-old son, David, who had already made a voyage in the Arcturus with Dr. Beebe and had published his "David Goes Voyaging." This was the staff of the expedition for which the ship had been chartered and the cruise was to extend throughout the summer and penetrate into Baffin Bay as far as Cape York in $76^{\circ} \mathrm{N}$. latitude.

For my own expedition of six men I had made a contract with Director Putnam under the terms of which we were to be taken aboard the Morrissey as passengers and were to be set down at the head of the Maligiakfjord, about thirty miles east of Holstensborg in Greenland; except in the event of adverse weather conditions prevailing, when we were to be set down at Holstensborg upon the coast. Our entire party qualified as "able landlubbers" and were subject to call on deck at any 
hour of the day or night to make or shorten sail, though we were not required to go aloft.

After having deposited us with our stores the Morrissey was to go about its cruising work in Baffin Bay, but return in September so as to bring us back to North Sydney. With a clear view of the hazards of expeditions like ours, Mr. Putnam and I signed jointly a letter in which it was agreed that the Morrissey would be at Holstensborg on September 18th and would find us ready to embark unless by radio other plans had in the meantime been arranged. If the ship should give us no information before October 10th, we were to assume that difficulty or disaster had occurred. We were to notify the Danish authorities and then shift for ourselves. As events proved the Morrissey suffered shipwreck far to the north, but eventually got off again in a crippled condition, took us on at Holstensborg, and in spite of nasty weather and a full gale got us all safely back to North Sydney.

The expedition which I directed was organized as a University of Michigan enterprise and was preliminary in its nature, having for its purpose the discovery of a suitable base at which to establish an aerological station for study of the peculiar glacial anticyclone of Greenland, the northern Pole of 
our wind system fixed above the great dome of ice and snow which submerges the greater part of the Greenland continent. We had come prepared to make preliminary studies of the upper atmosphere by means of balloons in addition to the usual meteorological observations at the ground level.

Besides the Director our party of six consisted of: Dr. Larry M. Gould from the geology department of the University of Michigan, secondin-command, geologist and photographer; S. P. Fergusson, from the U. S. Weather Bureau in Washington, aerologist; Dr. J. E. Church, Jr., an alumnus of the University of Michigan but now from the faculty of the University of $\mathrm{Ne}$ vada, meteorologist; Ralph L. Belknap, from the Geology Department of the University, surveyor; and Paul C. Oscanyan, Jr., of New Jersey, radio operator. In addition to the members of both expeditions the Morrissey carried besides the master, Captain "Bob" Bartlett, his brother "Will," the mate, and a crew of four men besides the cook and steward.

We were taking supplies and equipment sufficient for the summer only, but it was hoped to test out conditions with a view to more extended studies so soon as a suitable base had been discovered. For these studies clear skies were, if not 
absolutely essential, at least highly desirable, and the Holstensborg district even upon the coast enjoyed the reputation of having a somewhat dryer atmosphere than neighboring sections of the Greenland coast. The distinguished Swedish Polar Explorer, Dr. Otto Nordenskjöld, had in 1909 gone into the Holstensborg hinterland between the coast settlements and the margin of the inland-ice, and had reported still dryer conditions of atmosphere as the ice is approached. I believed that this was probably due to the protection afforded by the long arm of ice which at a high level and to the southward pushes outward toward the coast so as to condense the moisture from clouds arriving from the south and southwest.

Late on the afternoon of the twenty-ninth, the Morrissey got into the narrowing approaches to the straits of Belle Isle, where to our delight we found that the ice had already, under the influence of the southerly winds, moved out into Davis Strait leaving behind only a few growlers and isolated larger bergs. By midnight we had passed the Belle Isle light and early next morning were going slowly ahead in a thick fog under our engine power. As I emerged on the deck from the after cabin, "Old Tom," who was at the wheel, nodded his head toward the starboard beam 


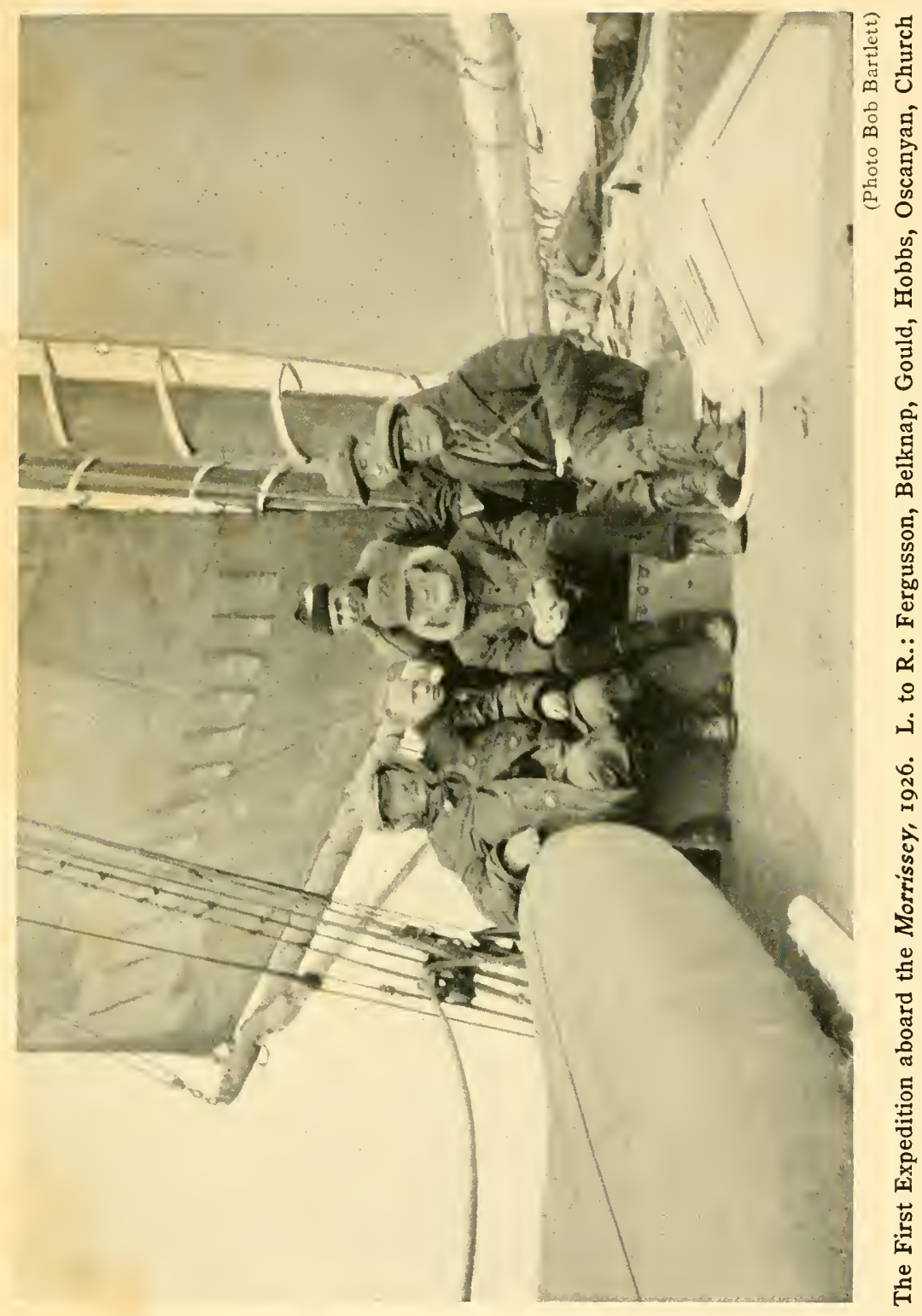



with the remark, "There's a big one, Sir!" Peering through the fog in that quarter I was able faintly to make out a towering mass of ice apparently not a hundred yards off. By mid-forenoon it had become less thick and we were now able to see about us in all directions the pan-ice with scattered fleets of icebergs. As many as one hundred bergs could be counted at once. In the evening, an impromptu concert was given in the 'midships cabin by Young playing his "Katydid," a shrunken edition of a violin, Kellerman his violin, Dunrud his banjo, and Streeter the mandolin.

On the early morning of July 1st, as we lay in our bunks, the bell rang to stop the engines. This was soon followed by the signal "half-speed ahead," followed by frequently changing orders and sometimes by hard bumps from growlers and small icefloes. We had now entered a field of brash-ice which had blown out from the Labrador coast, and all day long, with sails furled, the ship proceeded at half-speed conned from the crow's nest so as to take advantage of lanes through the ice field. We were soon aware that it had grown much colder, and today for the first time a fire had been lighted in the stove of the after cabin. Toward evening we came out of the ice field into a heavy cross sea stirred up by the northerly gale a few days earlier 


\section{NORTH POLE OF THE WINDS}

in connection with the southerly winds which had brought us forward. All hands were piped on deck to hoist sails. With many of the land-lubbers ill in their bunks and with the husky Peary on duty in the engine room, our inexperienced people toiled hard with a "Yo Ho" before we had the heavy mainsail up and were left with badly lamed muscles. We could now understand the difficulties under which Captain Bob had labored when on his recent trip from North Sydney to New York he had in bad weather carried on with a crew of only six men including the cook and steward.

All through the night and on Friday, July 2nd, we thrashed about in the heavy swell. There was but little wind and the sails flapped and wore the gear more than during a full gale or through months of ordinary sailing. When the mess call sounded there were few who responded or could do justice to the Friday menu of boiled cod in bacon fat. The heavy seas continued throughout Saturday the third of July, though the wind had now shifted to the northeast and the ship was close hauled. After mess we got the Captain "going," yarning of the great events in which he has borne so noble a part: the long association with Peary in his great Arctic explorations, the loss of the Karluk and the long trek which followed along the 
Siberian coast to Alaska. His devotion to Admiral Peary is fine to see.

At midnight all sail was taken in, but before morning with her canvas furled the schooner was rolling so badly that the foresail and jib were again hoisted. I was up early and was standing near the wheel when four pistol shots came up through the skylight. It was Dunrud who was thus intimating to us that this was the "glorious Fourth." The sea had now become like glass, fortunately with no ice, and throughout the day with fair visibility. By dead reckoning Captain Bob gives our latitude as $62^{\circ} 30^{\prime}$. Bottles containing cards which give the position of the ship and the date are sealed up against the entrance of sea water and are thrown overboard. If later picked up these will give valuable knowledge concerning ocean currents. At dinner we have to do with other bottles-of ginger ale-for Mr. Putnam has wisely taken on board no supplies of spirituous liquors, and so in ginger ale we celebrate our national holiday.

By the fifth we had had no observation of the sun, for there has been much fog though with brief intervals of good visibility. Several times the sun almost emerged from the clouds and the captain has come hurrying down into the cabin 
for his sextant, only to be disappointed, for no sooner is he back than the sun is again hidden. We badly need an observation of the sun for we are now approaching the Greenland coast with its thousands of rocky islands and half submerged reefs. We note sharp changes of temperature. A thermometer which Fergusson swung on deck gave a reading of $59^{\circ} \mathrm{F}$. in the morning and $38^{\circ} \mathrm{F}$. in the afternoon. A little after eight in the evening the cry of "Land Ho" came down to the cabin where Fergusson was just finishing a very interesting talk on our meteorological instruments. We rushed on deck and saw clearly to starboard the high Greenland coast with one area where tongues of ice could be made out.

While we were watching the coast a quite remarkable cloud in nature and form resembling thunder-heads was seen massed along the coast, and this could be explained by cold air riding out over warmer. A little later this developed into a white uniform mass near the surface of the sea beneath a dark nimbus-like curtain.

In the night following we had a gale and with sails set made a speed of from eight to ten knots, the shore always in sight about five miles off on the starboard beam. All night the Captain was up studying the mountainous coast; for Greenland is 
without beacons, has relatively few soundings away from the fishing banks, and Captain Bob with all his visits to North Greenland had never once made port in this section or even sailed near the coast.

After breakfast on the sixth the engines were stopped and still making nine knots under sail, the Captain and I studied keenly the features of the shore, comparing them with our maps. We believed now that we were able to recognize the entrance to the great Söndre Strömfjord. About nine-thirty a sail was made out far ahead and almost at the same moment with our binoculars we had made out a camp on a low island to starboard. The ship was at once brought into the wind and the motor-boat lowered. Putnam, Peary, Dunrud and Will Bartlett, the mate, got into her. A high sea was running and the motor as usual temperamental, so that there was some difficulty at first in getting off. However, Peary soon had the motor under control and the boat started toward the shore. As soon as the Eskimo encampment made out the motor-boat leaving the ship, two men in kayaks put off from the shore. Soon we saw one of them reach the motor-boat and be taken on board while the other returned to the shore. As the Eskimo came over the side Captain Bob pronounced the word Holstensborg. The Eskimo 


\section{NORTH POLE OF' THE WINDS}

promptly pointed approximately in the direction where we had located the settlement. He was given the helm and at once set the course. He seemed to be entirely at home at the wheel and about the middle of the afternoon he brought us through its narrow entrance into the harbor of Holstensborg, which is hidden from the sea and easily missed. As we were later to learn, the approaches to the harbor are strewn with dangerous reefs, so that a definite narrow course must be followed to insure safety.

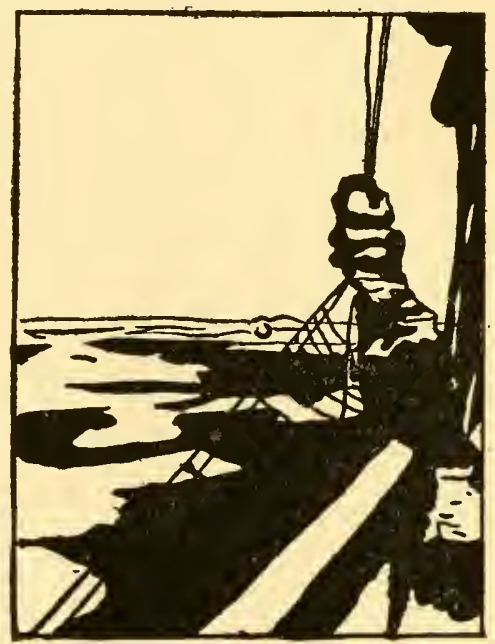




\section{CHAPTER II}

IN CAMP ON THE MALIGIAKFJORD

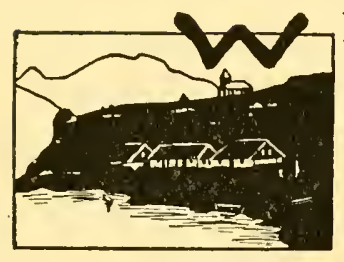

HEN anchor was dropped in the harbor of Holstensborg, Mr. Putnam, Captain Bob, Dr. Raven and myself at once went ashore to meet the local Governor; but unknown to us he had already set out for the ship. On reaching the shore we learned of this and at once returned on board to meet the representative of Danish authority in this outpost of the kingdom. With Governor Bistrup was Helge Bangsted, a wellknown Arctic explorer who spoke English and acted as interpreter. Bangsted had been a member of the latest Thule Expedition of Dr. Rasmussen in Arctic America, and he was now returning from an independent expedition which he had just made on the Greenland ice-cap near the 


\section{NORTH POLE OF THE WINDS}

latitude of Umanak. Governor Bistrup had been born in Greenland the son of a Danish Grovernor, and almost his entire life had been spent in the Greenland coast settlements. Both Governor Bistrup and Mr. Bangsted were to play important rôles in connection with our Greenland Expeditions.

No one is allowed to land in Greenland without a special permit from the Danish Government, but our papers were soon found to be in order and the Governor now exerted himself to supply the furs and other articles still necessary to our equipment. We were invited to take coffee at the Governor's residence, which is above the harbor and is entered through an impressive gateway formed from two ribs of a Greenland whale. The men and women of the Governor's household were now invited by Mr. Putnam to be his guests at dinner on the Morrissey, where Billy the cook did his best to make a sailor's fare attractive to the guests.

Mr. Putnam was anxious to sail for the North with as little delay as possible, and the Governor having sent on board an Eskimo pilot familiar with the navigation of the neighboring fjords, we weighed anchor as soon as dinner was over. Because of the shallow water in the straits at Sarfanguak, it was necessary to first go down the coast and 
sail up the Ikertôkf jord. As it was light enough for navigation throughout the night, Streeter saw that Billy had coffee kept hot for us throughout. I searched eagerly the shores of the fjord for possible camping sites, but without success. We were later to learn that though the coast land belt is well supplied with water, this is generally found in basins which have no outlets and are widely scattered over the plateau. Streams which enter the fjords are rare indeed.

The morning began in a drizzling rain and we soon came opposite a gulls' rookery perched on the almost perpendicular cliff at a bend in the fjord. A rifle shot echoed along the fjord and flushed the gulls by the thousand. At one point Putnam, Streeter and I went ashore to leave a note at an Eskimo fishing camp to announce our arrival to Magister Porsild, Director of the Danish Arctic station at Godhavn, who was known to be cruising somewhere hereabouts in his motorboat.

Near the little Eskimo settlement of Sarfanguak the Morrissey dropped anchor and we went into the house of the manager, David Olsen, to have coffee and cake. Olsen is one of the most remarkable Eskimo-Danish half-bloods that Greenland has produced. For his services to the State he has 
been decorated by the King of Denmark. Later we were to have many occasions to thank this efficient manager for valuable help, though we communicated with him by a combination of pantomime with the few words which we had acquired of each other's languages.

As we set sail from Sarfanguak I scanned with even greater care, but with as little success as before, the shores of the Ikertôkfjord for possible camping sites. At last we turned sharply to port to enter the trident-like head of the great fjord, and as we did so our Eskimo-pilot reported that we could go no further in the ship since the water was now rapidly shallowing. Hard by the western shore we drop anchor in seven fathoms, the motorsailer of the Morrissey is lowered overside, and with Peary as our engineer, Gould, Church, Streeter and I set out to examine the head of the fjord. Before we have advanced a mile there opens out on the east side a deep amphitheater which is recognized as a true glacial cirque that has been in part submerged through sinking of the shore, and here many of the conditions for a suitable camp site are realized. The depth of water is sufficient for landing, the floor of the amphitheatre is sufficiently flat for tents, and, best of all, a source of fresh water is apparent in a cascade which 


\section{IN CAMP ON THE MALIGIAKFJORD}

tumbles over the high rock walls and as a purling brook makes its way out to the shore. For our balloon studies such an amphitheatre is of course ill suited, so we proceed some four miles farther up the fjord to near its head, where the ebb tide

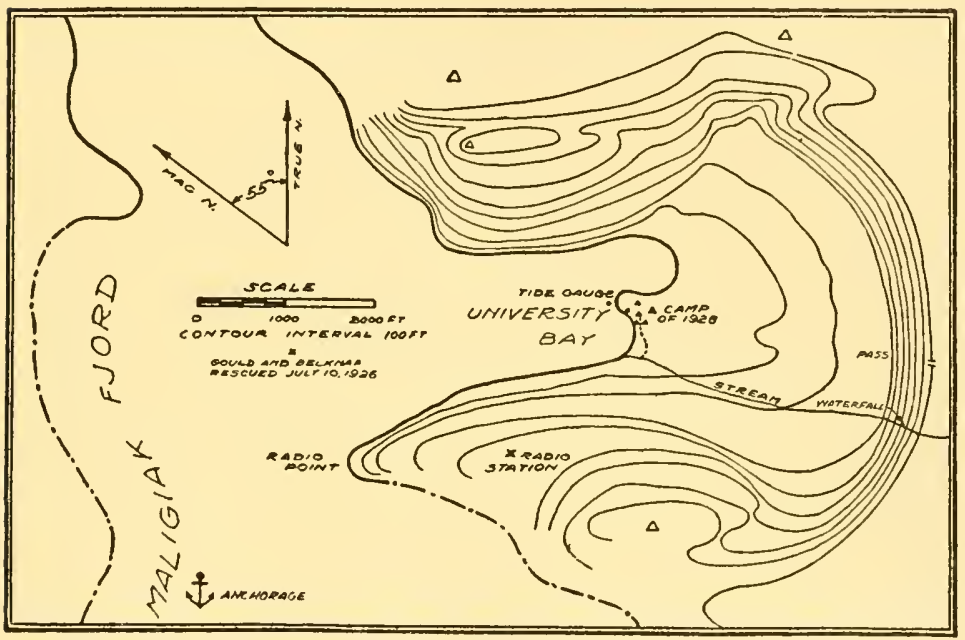

and the shallowing water make it necessary to return. We note other camping sites, but I select the one first seen less than a mile from our anchorage.

While we have been away the captain has set the crew to work getting our stuff up on deck with the aid of Belknap and Oscanyan, who have had to do with the storage of our material at New York and at North Sydney. The three dories belonging 


\section{NORTH POLE OF THE WINDS}

to the two expeditions have been placed side by side, studding and boards from our lumber supply have been laid across them and securely lashed. As soon as this improvised lighter has been loaded the crew, two Eskimos, and members of both expeditions pile on and are towed swiftly to the landing behind the motor-sailer.

No sooner are we on shore, however, than we are fiercely attacked by swarms of mosquitoes, and though we have come provided with insect-proof tents, head-nets, gauntlets, and mosquito dope, it is not possible to get out at once these necessities of any Greenland or in fact Arctic adventure. Wherever there have been glaciers basins of water have been left behind for the breeding of mosquitoes and other insect pests. On this Greenland coast the black fly and the little sand flies called by the Canadian-Indians "no-see-ums", are especially abundant and for a portion of the season all these insect pests are found together.

For a second load on the lighter our drums of gasoline weighing nearly a ton are set ashore and with some difficulty are rolled up the bank and left above high water mark. The last load is put on in some haste and it is not possible to make sure that all our supplies have been removed. In addition to the stores of the two expeditions the Mor- 


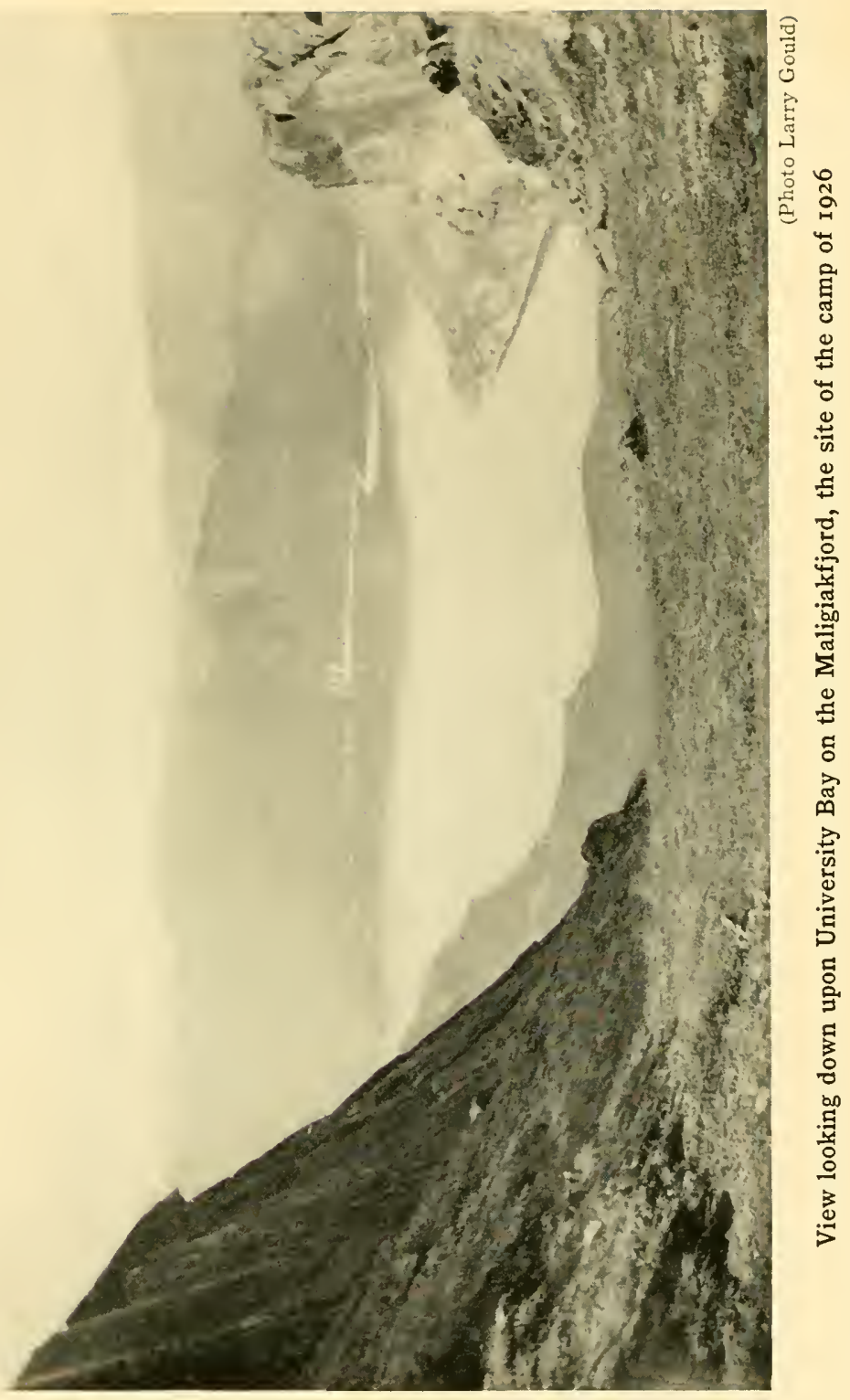


rissey carried supplies for the Eskimo station of Dr. Rasmussen at North Star Bay. In order to find place for everything the stores of the two expeditions could not be kept entirely separate, for economy of storage made size and shape of individual boxes rather than their content the determining factor in their distribution on board. Our sacks of sugar got packed near the gasoline engine and were in part impregnated with so much motor gasoline that even our Eskimo helpers refused to eat it. We made, however, hurried journeys through the ship and could only hope that no very important articles had been left on board.

And now the time had arrived to say good-bye to our shipmates of the Putnam expedition and to hope that a kind Fate would bring us all together again in September for the return voyage to Nova Scotia. Our stores have been hastily dumped on shore above the high tide level in a confusion which suggested the salvaged wreckage from a sinking vessel. On this pile of lumber, casks, cases and rolls we perched ourselves and watched the beautiful lines of the Morrissey as her anchor was weighed and she disappeared into the Ikertôkfjord behind the headland.

The last forty-eight hours have been hectic ones and without sleep for some of us, but the weather 


\section{NORTH POLE OF THE WINDS}

is now good and we do not have to fear the coming of night and darkness. As soon as our sleeping tents have been pitched and our bedding placed ready, we start to get out the cooking utensils and prepare supper, for all are very hungry after the arduous work of landing the stores. The boxes containing our kitchen and tableware are nowhere to be found, but it is only after a thorough search that we are compelled to admit that they must have been carried off on the Morrissey. While this is not a misfortune of major proportions it is none the less a very serious handicap. Something we must have to take the place of spoons, and after search along the shore some small mussel shells are found and not without scorched fingers each of us dips his shell into the soup pot (a large jam can) after the manner of primitive peoples. This makeshift for spoons is necessary for the first few meals only, for our expert instrument-maker and handy-man, Fergusson, gets out his drill and prepares wooden handles for the mussel shells. As soon as there are empty cans he fashions from the corners of square cans a scoop type of spoon with handles of twisted wire taken from the replacement stores of the radio outfit. From the same wire forks are fashioned, and our sheath knives serve us as table knives. 
The insect pest is found very trying especially by those who are without experience in the Canadian wilderness. Both because he is more easily poisoned by the mosquitoes and because his deft manipulation of instruments does not permit of the regular use of gloves, Fergusson suffers most, and his hands are almost constantly swollen to surprising proportions. We soon find that if we are to eat our meals in comfort, we must protect ourselves by wearing our head-nets throughout. No one of us would think of leaving camp unprotected with a head-net.

So soon as the camp had been organized and everything made snug for possible nasty weather, Gould and Church on the eighth with some help from Belknap and the Director began the construction of our hut in which the instruments and more perishable supplies are to be protected. No lumber is obtainable in Greenland and the building materials have all been brought with us on the Morrissey. From $2 \times 4$ studding a frame eight feet square on the ground and eight feet high on the front sloping down to four at the back was put together. This frame was then boarded in, roofed and in part protected on the sides by malthoid paper. In the meantime several reconnaissance trips have been made by small parties 
that have gone beyond the head of the Maligiakfjord to the eastward, and westward across the fjord in the direction of the coast. As soon as time could be found Belknap with the aid of the Director began to prepare a map of the district as far as the head of the Maligiakfjord.

Oscanyan, our radio operator, early set to work to prepare and erect the radio mast of jointed bamboo thirty-five feet in height which we had brought with us. It was at first set up some distance back of the hut but without securing any contact whatever. It was then concluded that the high rock walls of the amphitheatre prevented any rays . going out or coming in except at the west where the amphitheatre opens toward the bay, and it was therefore decided to move our radio station to the summit of the headland four hundred feet high and lying southwest of the camp. The heavy Burgess $\mathbf{B}$ batteries it was necessary to ferry across the bay and pack them up the steep slope to the top. This work fell largely to our strong man, Gould, aided by Belknap and myself, since Oscanyan was kept busy getting his equipment sorted out and later assembled on the headland. The radio station itself was merely a small tent in which we had both short and long wave receivers that in the new position gave us for the greater part of 


\section{IN CAMP ON THE MALIGIAKFJORD}

the time excellent reception from the United States and Europe, as well as occasionally from far more remote countries. Our transmitter was a simple short wave instrument using a $7 / 2$ watt radiotron, with which we expected to maintain contacts with the Morrissey as she cruised about in Baffin Bay. This contact was essential at least during the late season, since we must learn the position of the vessel in time to get down to the coast before her return.

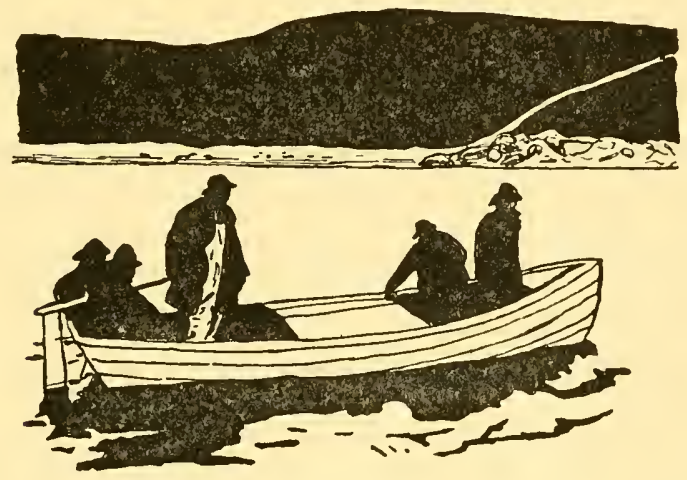




\section{CHAP'TER III}

THE MOTOR-CANOE SWAMPED AND THE RESCUE

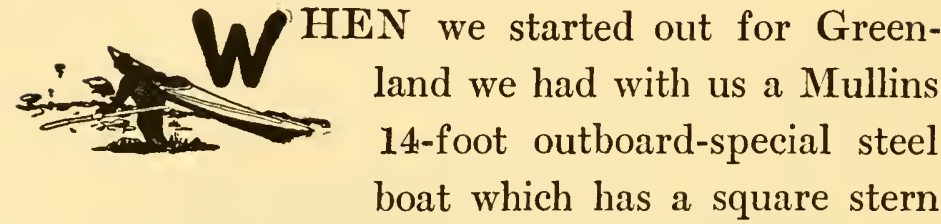
and was intended for use with a Lockwood L.A. twin 3 horsepower outboard-motor loaned us by the manufacturer. When we came to embark at North Sydney the deck of the Morrissey was already so crowded with freight that no place for the Mullins boat could be found, and to our great regret it had to be left behind. In later expeditions when he had one of these boats we learned of their great adaptability for our purposes and it was in this boat that the Rockford flyers were rescued during a very high sea. On board the Morrissey Mr. Putnam had two Newfoundland dories which could be nested together; and so we purchased one of this type to replace the Mullins boat. 
The dory is a very practicable and amazingly sea-worthy boat, but it has a sharp stern and the stern-post slants inward toward the middle of the boat. Furthermore, the freeboard is so high that the screw of our motor would be largely out of the water. It would be difficult to find a type of boat which offered greater difficulties for attachment of the outboard motor. But these were very cleverly solved by Gould. The stern of the dory was cut back a distance of about a foot extending downward from the gunwale about ten inches. $\mathrm{He}$ then made a new water-tight stern and $a$ deck running out from its base to the rudder-post. On the outer edge of this deck a cleat was erected for the clamp of the motor. The dory thus modified never gave us trouble during the three seasons and was indispensable to us.

We had also taken with us two Chestnut canoes made at Fredericton, New Brunswick, one of them the prospector's model and the other with a square stern to be used with outboard-motor. When used with the motor this canoe is of course a high speed boat and even when weighted down in the bow is hardly safe except in quiet waters.

The Greenland fjords are very treacherous for boat navigation. Gusty winds sweep down upon them and these have often a limited distribution, 
so that a boat passes abruptly from quite safe water into very rough seas. Further difficulty arises from the strong "rips" at the turn of the tide. A tide gauge loaned us by the U. S. Coast and Geodetic Survey was set up for regular measurements off our camp on University Bay and the extreme range of water at the spring tides measured as fifteen feet. About the heads of the fjords there are deep deposits of sticky glacial muds which are exposed at low tide over considerable areas, and we were more than once marooned for hours at points distant from our base waiting for the tide to rise sufficiently for us to get off.

In order to understand how we were able to save the lives of two of our party in our worst accident of the summer, it will be necessary to refer to our attempt to replace the missing cooking utensils and tableware. We had been in camp but a few days when an Eskimo paid us a visit coming from Sarfanguak in his kayak. He spoke no English but it occurred to me to send a message by him to David Olsen, asking him to send us the cooking vessels and table utensils of which we stood in such need. Since Olsen knew no English the letter had to be largely a pictograph. I first drew a small teaspoon and placed beside it the figure six. The Eskimo looking over my shoulder nodded 
his head to show that he understood. Below it a larger spoon was drawn and the figure six placed beside it. More nodding of the head and now a broad smile. A table knife and a table fork were each in turn drawn and the figure six added. And so on with each dish, fry pan or boiler needed. Just as I was about to fold this document an idea came to me. We had obtained from David Olsen several cans of ptarmigan, the Arctic pheasant quite abundant in Greenland, and four of these birds after parboiling had been sealed in each can. On a chance $\mathbf{I}$ decided to add as a postscript to my letter a request in English that a number of cans of ptarmigan be sent in to us with the cooking utensils.

This seemingly unimportant postscript to my pictograph message played a most important rôle in connection with the accident; for Olsen being unable to read this message sent the document by a kayaker down to Governor Bistrup at Holstensborg. 'This trip to Holstensborg involved considerable delay. The Governor decided to send the articles requested in a whale-boat rowed by Eskimo women but as usual with one man as coxswain. When this whale-boat appeared under sail off our base with two kayakers flanking it on either side it was a great surprise to us. When the cargo had been delivered and the crew had curiously in- 
spected our camp, they departed in the whale-boat to return to the coast.

This was the day that Larry Gould and Belknap had fastened the outboard motor to the canoe and were testing its performance on the fjord. Church, Fergusson and Oscanyan were busy about the storehouse while I with one of the Eskimo men was standing on the shore observing the performance of the canoe. I had become somewhat worried because Gould was venturing so far out, at least three-quarters of a mile from the shore where the water seemed very rough. By this time the whale-boat was well out from shore and moving rapidly away. As I continued to watch the canoe I suddenly observed that the heads of the two men went out of sight behind a wave, reappeared again and then disappeared, and I thought I made out a faint cry for help. As I turned and shouted for help the kayaker, who had also been watching, launched his kayak and paddled swiftly to the scene of the accident. It was probably not two minutes before Oscanyan and I had launched the other canoe and were pushing it rapidly through the water, while Fergusson and Church in some way managed to launch the heavy dory and with a single pair of oars only, followed in our wake.

The water of the fjord is icy cold. Would the 


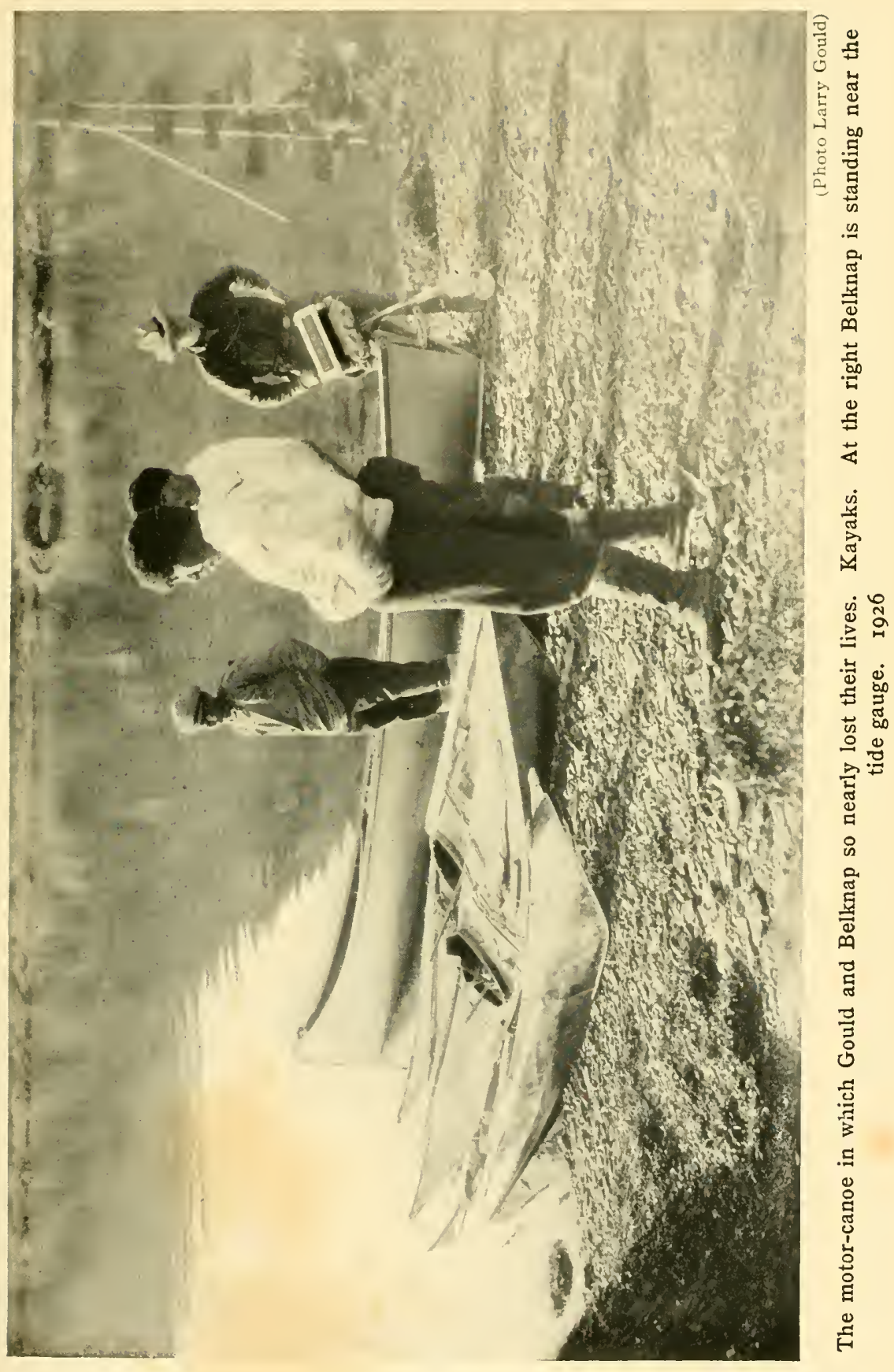



men be able to retain their hold on the canoe until help arrived? It seemed very doubtful.

As we paddled feverishly I got a glance at the kayaker who was making wonderful speed, and we soon became aware that the crew of the whaleboat far out in advance of us had noticed the capsized boat and they also were now rowing hard to the rescue. Long before we arrived we saw the kayaker reach the scene and get hold of the men still clinging to the overturned canoe. It seemed hardly a moment later when the whale-boat came up and the men were pulled in. When Oscanyan and I came up in the canoe the motor-canoe was being drawn across the stern of the whale-boat and Gould shouted to me that they were all right and urged me to turn about before we should be swamped in the rough water which we had already entered. The canoe was turned about at once and hurried back to camp where we arrived first. While I prepared hot tea Oscanyan brought the Arctic sleeping bags into the new storehouse where the chilled men were removed from their wet clothing and with teeth still chattering placed in the sleeping bags. In a few hours they were quite themselves again, but except for the opportune presence of the kayaker and the women in the whale-boat this accident might have had a tragic ending. If 
the cooking utensils had been promptly brought from Sarfanguak they would have reached us at least a day earlier, and so the effective rescue may be ascribed to the postscript of the message, which message with its crude pictures Governor Bistrup has today framed in his office.

It was on the twenty-third of July, or little more than a fortnight after our arrival on the Maligiakfjord that Oscanyan, our radio man, was able for the first time to establish contact with the Morrissey cruising in Baffin Bay. On the following day messages were received in news dispatches from the United Press Radio Station at Garden City, Long Island. These summaries of the world's news were read to us as we sat at breakfast next morning, and from this time until the breakdown of the Garden City plant late in the season, the morning newspaper became a feature of our breakfasts whenever we were in camp.

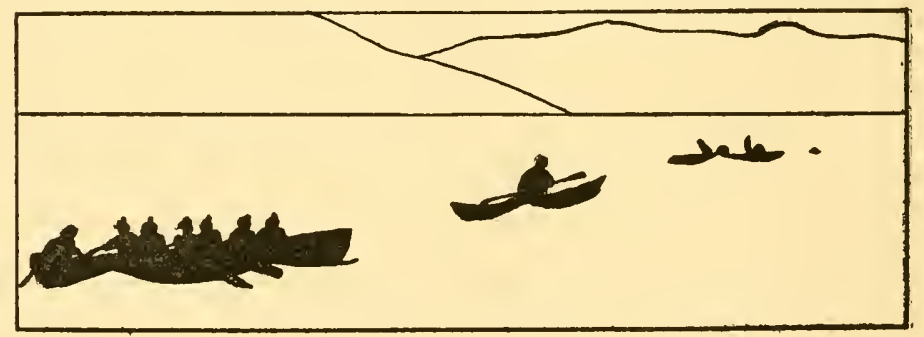




\section{CHAPTER IV}

THE WINDS FROM THE "GREAT ICE"

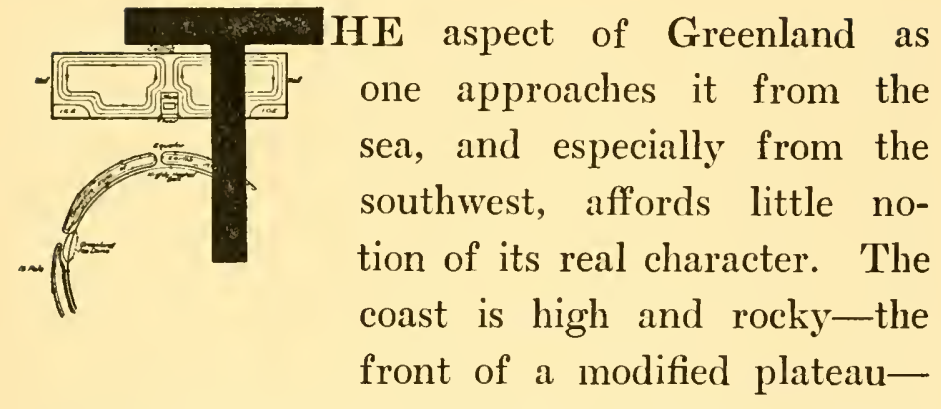

and this is deeply intrenched by a system of steepwalled fjords, easily the greatest of its kind in the world. Over wide stretches the front wall of rock is flanked by a narrow belt of low islands, at most a few hundred feet in height, and the entire western coast is skirted by thousands of rocky islets or skerries and half submerged reefs.

Behind this ribbon of coast-land, and generally hidden from the sea, is found the Greenland of the interior, a vast flattened dome of ice and snow 
which rises to heights of from 9,000 to 10,000 feet. The Greenland of the Eskimos, of the Government officials, and of the sealing, whaling and fishing industries, is that of the coast-land ribbon; and all the settlements are to be found upon the coast usually at the mouths of the larger fjords.

When we enter the region of the "Great Ice" we are in another world and one of which there is but a single additional example, the Antarctic Continent near the other end of the earth's axis. Over these great masses of ice and snow no life has been found, and our knowledge of them has been obtained from the reports of the few hardy explorers who have penetrated the white world of snow and ice. On the northern ice-cap Baron Nordenskiöld in 1883 and Peary in 1888 penetrated well toward the interior from the west coast, and in $1888 \mathrm{Nan}$ sen accomplished the first crossing of the ice in latitude $64^{\circ} \mathrm{N}$. toward the southern end of the continent. In 1892 Peary in the greatest sledge journey ever carried through up to that time made a double crossing toward the northern end of the continent, and in 1895 he again made a double transection near the same latitude. The exploration of the Greenland ice-cap was not again taken up until 1912 and 1913 when three independent expeditions each succeeded in crossing the conti- 
nent at points farther in toward the central area. These were made by a Swiss scientist, Dr. Alfred de Quervain, within the south central portion; by a Dane, Captain J. P. Koch, within the broadest north-central region; and by another distinguished Danish explorer, Dr. Knud Rasmussen, in the extreme northern zone near but south of Peary's transections of 1892 and $\mathbf{1 8 9 5 .}$

From all these explorations we have learned that the inland-ice of Greenland, the ice-cap, is in form very simple and best described as shaped like a watch crystal; that is, very flat except near the edges, where its outward slope increases at first gradually and then at greatly accelerated rates. The outline of Greenland closely resembles that of a human left ear, since the straighter side is to the left or west.

The interior of this northern ice-cap of our globe is probably the coldest region in the northern hemisphere, though it is probably surpassed in cold by the interior of the Antarctic Continent. It is a mistake to suppose, as so many do, that the North Pole of the earth represents the maximum of cold. In the winter time it is colder in central British America and in central Siberia than it is at the North Pole, and along both these northern coasts the temperature rises when the wind blows from 


\section{NORTH POLE OF THE WINDS}

the Pole and falls whenever it blows from the south out of the interior of the continent. Over the interior of Greenland it is intensely cold both summer and winter, for those who crossed the Greenland interior in the summer time found temperatures far below the zero of the Fahrenheit scale.

Because of the vastness of the Greenland ice-cap the air above it is constantly being cooled through contact; and because the surface of the dome has everywhere an outward slope, this cooled air slides outward to replace warmer air upon the sides. This motion is first slow but increases at a rapidly accelerating rate, like that of all bodies which slide on inclined planes under the influence of gravity. It was Peary, the great Arctic Explorer and discoverer of the North Pole, who first showed by observation this outward movement of the air over the Greenland ice-cap. Whenever he was going up a slope the wind was found to be always in his face, but on going down a slope it was found to be at his back. Thus the flow of the air along the surface of the ice resembles that of a liquid flowing down the slope under the influence of gravity.

But it is clear that air cannot continue to move outward from a center in all directions unless air flows into the central area to replace it, and, com- 
ing as it must from above, this air must in turn be replaced by that of inwardly blowing currents at some higher level. The complete air circulation above the Greenland ice-cap consists, therefore,

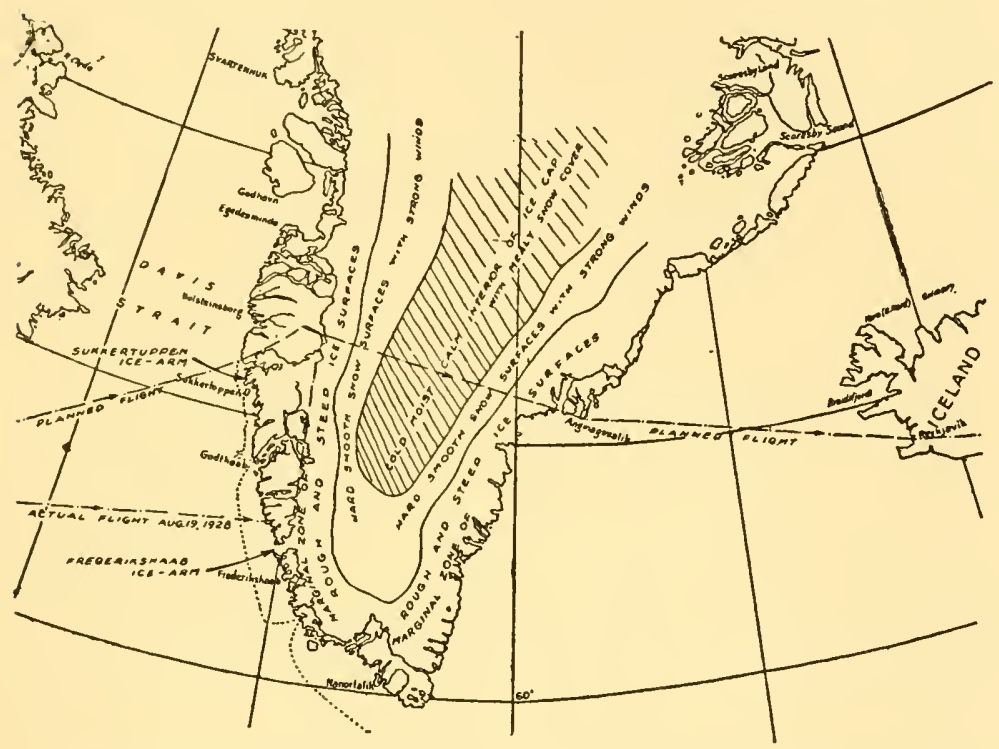

of high inward-blowing winds toward the central region, where air is slowly settling to the surface of the ice-cap, from which central area it reverses direction and passes out in all directions over the surface toward the margin of the dome. The Greenland ice-cap is thus the northern wind pole of the earth, which is technically described as the Greenland glacial anticyclone. The southern reversing area of our atmospheric circulation is the Ant- 
arctic glacial anticyclone located above the Antarctic Continent.

The winds of these two glacial anticyclones do not, however, blow directly down the slopes of the ice, because the rotation of the earth upon its axis brings about a deviation of wind directions such that in the Northern Hemisphere the deviation of downwardly directed currents is in the direction

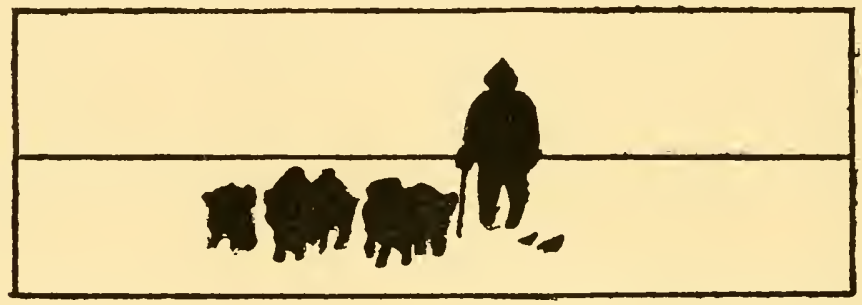

in which the hands of a clock move. In the Southern Hemisphere the deviation is exactly the reverse. Because of this deviation the winds which sweep down the western slope of the Greenland ice-cap reach the margins coming from the southeast, while those descending the eastern slopes come from the northwest.

Dr. de Quervain and Captain Koch while on their journeys across Greenland each passed through an interior region of no winds and of very intense cold, where dry and loose mealy snow lay beneath their feet. Before penetrating this cold central windless region, and again after emerging 


\section{THE WINDS FROM THE "GREAT ICE"}

from it, they each passed through zones of outward blowing winds which alternated in force between calms and fierce blizzards of hurricane force. Here in contrast to the central region the snow was packed hard by the storms so that the sledges, heavily laden as they were, did not sink into it.

The storms of the slopes of the "Great Ice" seem to "work themselves up" and then having

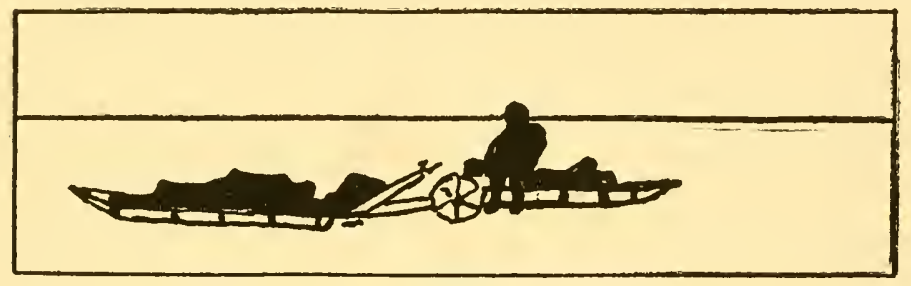

reached their maximum of force suddenly come to an end accompanied by a marked elevation of temperature of the air. This so-called foehn wind is the same in its nature as the foehn wind which blows down the north slope of the Alps, or the "Chinook" which sweeps down the eastern slope of the Rocky Mountains. Before the nature of such foehn winds was understood, they led to very erroneous ideas and were sometimes interpreted to indicate that a warm climate prevailed in the interior of Greenland. It is historically interesting that a military expedition with field guns was in the early days actually sent out from Scandinavia 
to subjugate the peoples supposed to reside in the interior of Greenland.

The explanation of the foehn, wherever it is found, is very simple, and accustomed as we are in these latter days to the use of pneumatic tires, it is not difficult to make it clear The surface currents over the Greenland ice-cap are set in motion by the cooling of the air in immediate contact with the ice surface, so that it slides outward down the marginal slopes through the influence of gravity. Only when the velocity of these air currents is high do they move downward fast enough to be heated through compression of the air as it comes to lower and lower levels. This is in every way similar in its nature to the elevation of temperature of the air which is being forced under pressure into a pneumatic tire.

Thus the storms from the "Great Ice" start slowly because to cool the air by contact requires considerable time, but they end suddenly because the compression of the air is rapid when winds move downward with hurricane force. When the foehn winds blow on the margins of the Greenland ice-cap, it is not uncommon for the temperature of the air to rise 30 or 40 degrees Fahrenheit in a very few hours.

Dr. H. Rink, long the Governor of South Green- 
land gave an excellent description of the Greenland foehn of the southwest coast. "Among the prevailing winds in Greenland," he said, "the warm land wind is the most remarkable. Its direction varies according to localities from true E.S.E. to true E.N.E., always proceeding though warm from the ice-covered interior, and generally following the direction of the fjord. ... When blowing for several days it is very dry, sometimes causing the snow to vanish without any water to become visible. This wind in consequence of always blowing from the interior, and having blown along a great part of its icy surface, must be considered one of the most important agencies in counteracting the accumulation of snow in the central region."

It was to study this glacial anticyclone over the Greenland ice-cap that our University of Michigan Expeditions have been sent out.

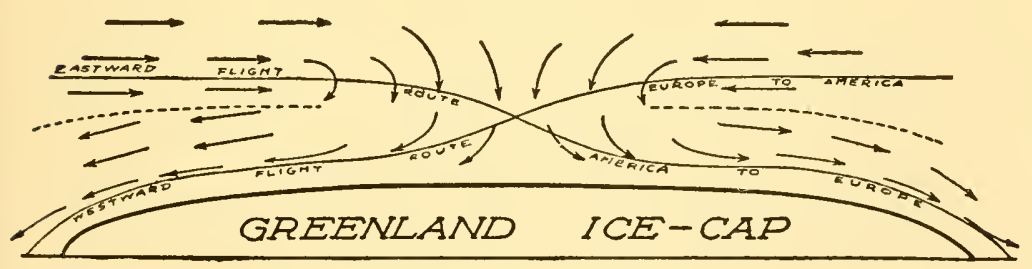




\section{CHAPTER V}

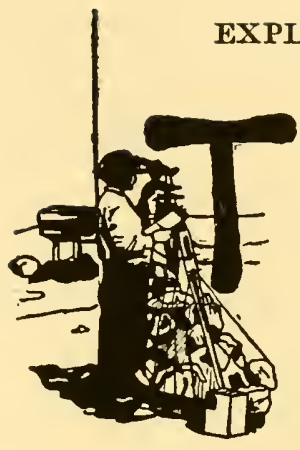

HE prime object of the Greenland Expeditions from the University of Michigan has been the study of the winds over the great ice-cap, the glacial anticyclone or North Pole of our wind system. The first problem which faced us was to select a place for the observing station which would be sufficiently near to the ice-cap to have the winds about it dominated by this North Polar circulation, and it was not at the time known how far outside the ice margin the outblowing winds extend.

We had come provided with equipment for a study of the upper air in addition to the usual studies carried out upon the ground; and for the upper air work two quite distinct types of balloons were required. One type, the pilot balloon, gives 
us information concerning the direction and the force of the wind at each level which is penetrated by the balloon while it remains in sight. 'The other type, the sounding or registering balloon, carries with it self-registering instruments and these must be recovered or the records are lost with the balloons. Within thickly populated countries, such as most parts of Europe, there is a large likelihood that the balloon will be seen by someone when it descends to the earth, or it may be later recovered, perhaps sometime after it has reached the ground. Attached to the light box of aluminum which protects the instrument is a placard generally written in several languages, and on this it is stated that a small reward will be paid to anyone who will forward the box to the address given. It is clear that such a type of balloon is not adapted for use in Greenland where the only inhabitants are in small Eskimo settlements along the coast. It seemed possible, however, that during quiet air conditions we might make use of a new deflating device for the balloon which would cause it to descend from any level fixed upon in advance.

The pilot balloons when inflated with hydrogen in the usual manner are about thirty inches in diameter; the hydrogen with which they are filled is obtained by dropping small pieces of the solid 


\section{NORTH POLE OF THE WINDS}

calcium-hydride into water enclosed in a metal gasometer, where the hydrogen gas is at once generated and led into the balloon. The lifting power of the balloon is measured by a specially constructed scale so that the balloon rises in the air at the nearly uniform rate of $\mathbf{1 8 0}$ meters per minute. At the end of each minute during the ascent the direction of the balloon from its starting point is fixed by reading two angles on the theodolite in the field of which the balloon is always kept focused at the center. In this way the path which is traveled by the balloon as it rises is determined and the force and direction of the wind obtained for each level until the balloon passes into a cloud or fades into the distance.

From July 2nd, 1926, when the first balloon run was made at our camp on the Maligiakf jord, one and often two or three ascents were made on each fair day, so that in all more than 90 ascents by pilot balloons were studied. As had been foreseen, the amphitheatre of rock within which our camp had been set up, was not favorable for our balloon work. The balloons at first rose from their initial position up so steep a course that the angles could not be read upon the instrument until a simple finder had been added by Mr. Fergusson, but as soon as the balloon had risen above the level 


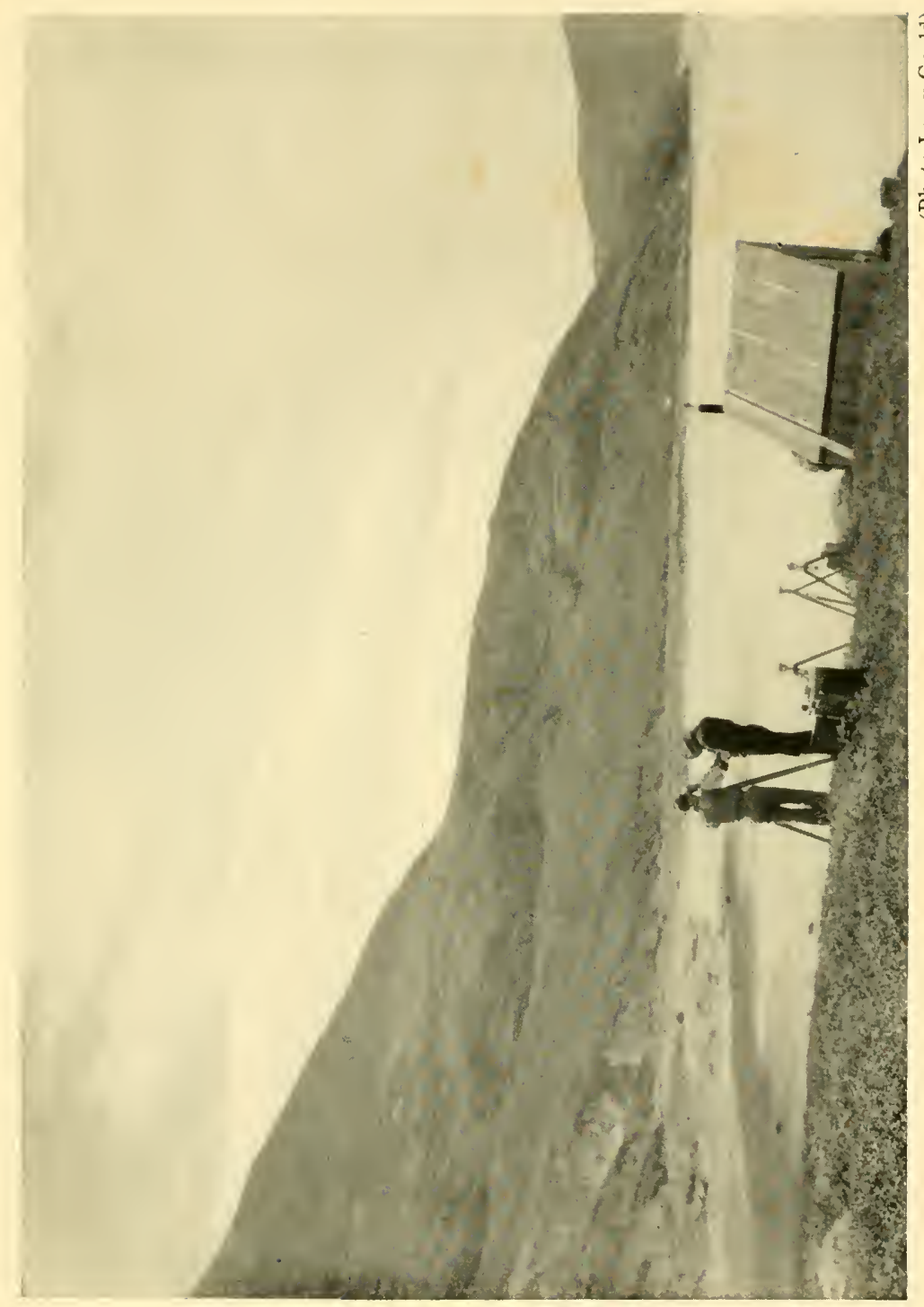

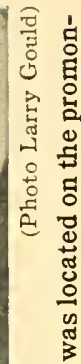

㤩

$\circ 0$

폰

o

岳

结

행

我

뜽

봃

空

过

동.

옹

정

害 ส.

형

욤

$\pi$

4

突

롱

bo

.

응 

of the rim of the amphitheatre it came under the control of the air currents characteristic of the district and might pass out of sight behind the rock walls. Fortunately the amphitheatre was open at the west and the balloon in most cases started off in that direction, to reverse direction later when it was at a higher level and so more easily seen from the amphitheatre. From this first season our pilot balloons were followed upon the average to an altitude of about 7,000 meters or about 4 miles above the surface of the earth. Many were followed to 10,000 meters, and one to 14,000 meters, or about eight miles. Rather generally they traveled westward toward the coast in the lower levels to reverse direction and disappear toward the ice-cap to the eastward, thus showing that for much of the time the winds above our observing station were controlled by ice-cap conditions.

The pilot balloon reveals the characteristics of the wind currents only, not the pressure, temperature, or humidity of the air. These important elements are supplied by the larger registering balloons, which carry instruments to record automatically the three elements at each level passed through by the balloon. Such balloons are also followed throughout their course by the theodolite in the same manner as the pilot balloons. The 


\section{NORTH POLE OF THE WINDS}

essential thing is to recover the balloon and its instruments, for otherwise not only has one wasted his time but incurred a loss of about $\$ 150$ of equipment with each ascent.

The Rossby deflating device, which we hoped would make possible the use of the registering balloons in Greenland, consisted of a light wooden rod projecting from the valve of the balloon and along which a rubber band is stretched. The valve of the balloon is kept open by a small spiral spring except when the pressure from this rubber band acting on the delicate spring keeps it closed. A fuse is now so attached that it will burn off the elastic band and open the valve at a height determined by the length of fuse taken. As the balloon rises in the air the smoke issues from the fuse until the band is reached and the valve opened.

It was, of course, necessary to work with such balloons only when the air was calm, and it was further necessary in our location to provide a float beneath the box of instruments so that if the balloon descended over the fjord the instruments would be kept afloat until rescued. Mr. Fergusson made a small float consisting of three pilot balloons inflated to a diameter of about eight inches and this float was suspended beneath the aluminum box which enclosed the delicate instruments, known 
as the meteorograph. Ours was the now wellknown Fergusson type of meteorograph which weighs only about one-tenth as much as the one in more general use. We could thus employ smaller balloons to lift this device, and Mr. Fergusson made use of two balloons each inflated to a diameter of about a meter and connected in tandem with the deflating device attached to the lower of the two. Connected to the other balloon was a parachute of red silk which would ease the descent after the lower balloon had been deflated.

For the first trial the elevation to be attained was fixed at only 400 meters, or slightly less than a quarter of a mile. With its attached instruments this balloon came down over the fjord and was rescued without difficulty by the prompt use of the motor-boat. The second ascent was adjusted for 1700 meters, or a little over a mile, and this time the descent was made into the amphitheatre near our camp and the record recovered. Encouraged by these successes, Mr. Fergusson set the third balloon for an altitude of 3000 meters, or nearly a mile and three-quarters. This time, unfortunately, the deflating device failed to function and the balloon was seen as it passed out of sight over the rim of the amphitheatre moving off to the northwestward with its precious burden. 
It has interested some people to know that this occurred on Friday, the thirteenth of August, but strange to say, this was not the conclusion of the incident. Just two weeks later, and hence also upon a Friday, Mr. Belknap and myself were making a reconnaissance across the fjord fully six miles away. In climbing a mountain he suddenly espied the red silk of the parachute as it lay tumbled upon the ground, and to our immense delight we found the meteorograph of the lost balloon with the records complete. When later examined the barograph showed that before its descent had commenced the balloon had reached an altitude of about 5,300 meters or nearly three miles. Thus as it seemed by a miracle we obtained a record such as had never before been made in Greenland and was unlikely to be repeated.

Such a piece of good fortune our wildest dreams had not pictured, and to Belknap and myself the opportunity seemed an excellent one for breaking the news gradually to Fergusson. So when we had reached the camp with our precious find I said to Fergusson, "Don't you think we ought to try and bring in from the coast a party of Eskimos and thoroughly explore the country to the northwest of us for the missing meteorograph?" My suggestion was met with the polite ridicule which it 


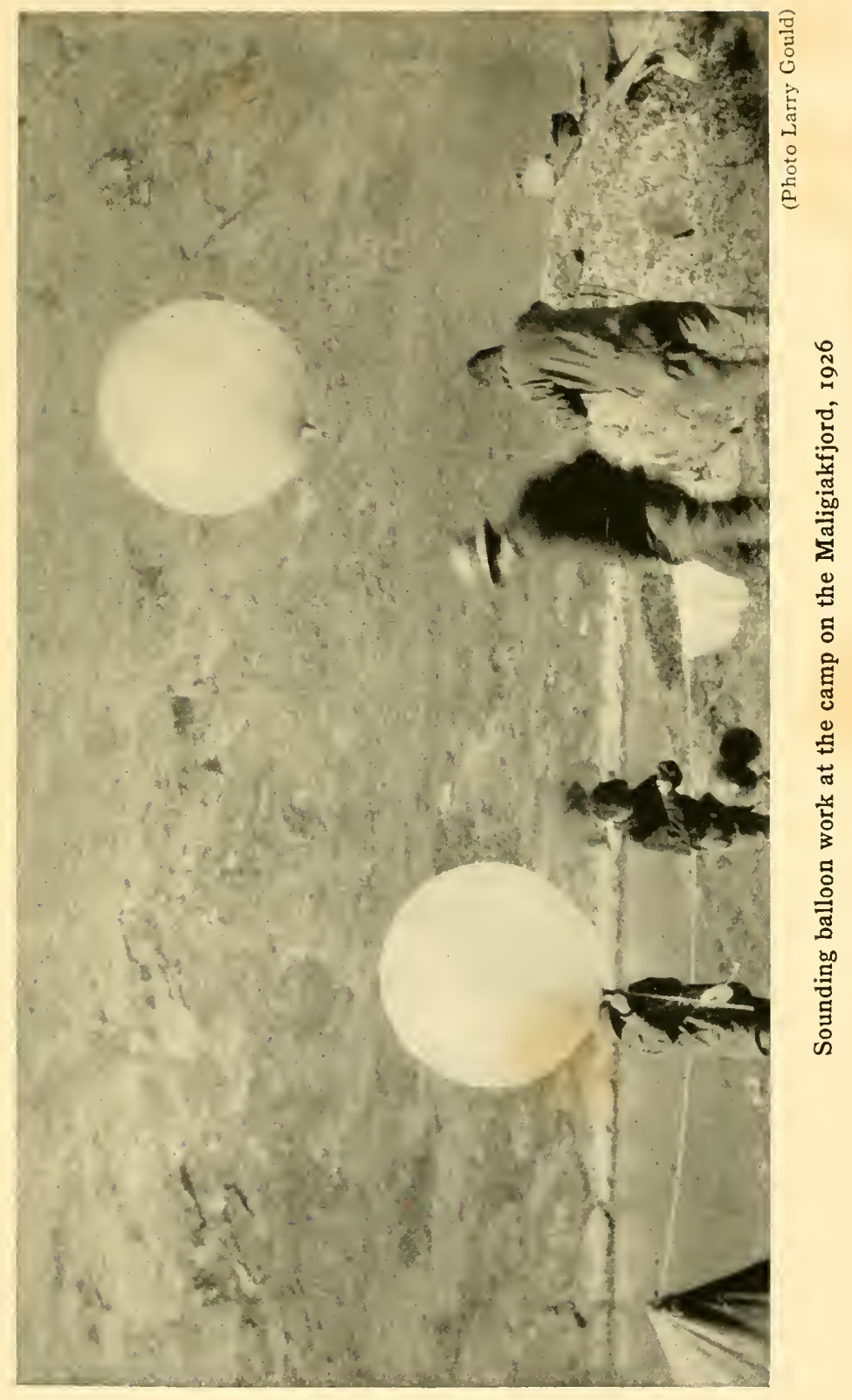



well deserved. There was not one chance in a million, said Fergusson, that such a search would be successful. When this idea seemed to have been sufficiently exploited we had the pleasure of telling our aerologist of our amazing good fortune, which we owed entirely to Belknap's keen observation.

As we sought to explain the failure of the deflating device in this instance, we were forced to the conclusion that the hydrogen as it was generated rapidly in the water of the gasometer, had forced spray into the balloon, and this having settled against the valve froze it solid before the balloon had reached the high and cold altitude of 3,000 meters. Taking precaution against a recurrence of this failure, we later made another high ascent upon a quiet day, but as the balloon rose above the amphitheatre it was carried out of our view behind the rim before the deflating level had been reached. The upper winds were less quiet than we had supposed, and this time the equipment was permanently lost to us.

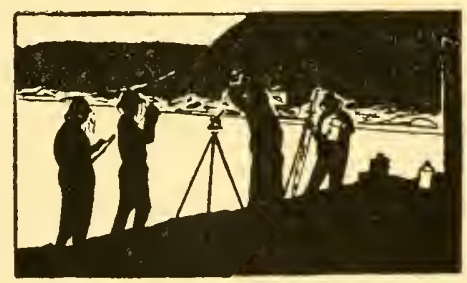




\section{CHAP'TER VI}

THE SUMMER EXPEDITION TO THE ICE-CAP

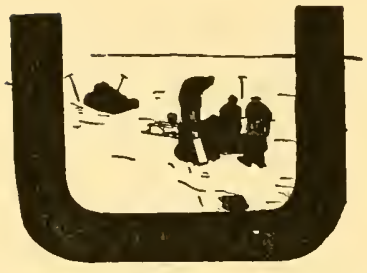

NTIL our daily balloon work was started at the base on the Maligiakfjord, we could not make preparation for the expedition across the tundra to the inland-ice and over its surface to carry out balloon ascents. We had already arranged to have four Eskimos sent in from the coast with an umiak or woman's seal-skin boat and a kayak or Greenland one-man boat. With these we were to take our lighter prospectors' canoe.

Dr. Nordenskjöld had in 1909 made an expedition along the route which we proposed to follow and had prepared a very crude sketch map of it, so that we knew the general character of the country. Abraham, one of our Eskimos, was the most experienced hunter in the Holstensborg dis- 
trict and had been in the hinterland. Moreover, Gould and I had made a reconnaissance as far as Taserssuak, a lake some twenty-five miles in length which extended directly eastward along our course. It was our intention to row, pole and tow the umiak up the river which empties into the head of the Maligiakfjord and then proceed in the umiak to the head of Taserssuak, where it would be cached to be made use of on the return journey. From the head of Taserssuak we proposed to proceed with packs, but taking the canoe with us for use on the scattered lakes, so far as should prove practicable.

For the ice-cap our fare was to consist solely of the excellent pemmican manufactured by Armour and a gift to us from Mr. Putnam, together with Knorr's erbswurst, or German Army pea-soup stock, biscuits and tea. During our three expeditions we have with entire success made the round pilot bread manufactured by the National Biscuit Company the main bread constituent of our diet. This biscuit has kept its crispness for six months or a year and the men have never seemed to tire of it. It has been put up for us in sealed four and one half pound cartons which are packed together six in a case. Two other staple articles of food used on our expeditions are "klim", desiccated whole 
milk, now manufactured by the Borden Company, and the several varieties of baked beans cooked in brick ovens and canned by Friends Brothers of Melrose, Massachusetts. The need of vitamines has been fully met by the vegetable products prepared by Mrs. Kelly at Pittsfield, Massachusetts, and widely used by Polar Expeditions under the name Cookellized products. Canned goods, bacon, oatmeal, coffee, sugar, etc., were also taken in as far as the head of Taserssuak.

For the ice-cap a primus stove and a supply of fuel were taken along, but up to the edge of the ice we believed we should be able to find the low Arctic shrubs, willow and birch, in sufficient abundance unless we remained longer than a day at one camp, in which case it might be necessary to range widely to obtain our necessary fuel. The green leaves of the Arctic birch which grows from one to two feet above the ground and is scattered widely over the tundra, contains an oil and once a fire is started the fresh branches burn with a hot flame.

As is usual with marching expeditions the heavy load in addition to food supplies is made up of tents and sleeping bags, and we carried with us the famous senior Arctic sleeping robes manufactured by Woods. Later, after we had had 
more experience, means were found to cut down greatly the weight of these items and without any serious sacrifice of comfort. A great advantage was gained by marching at night when the pest of insects is very largely avoided and the need of heavy sleeping robes obviated by timing our sleep when the sun is higher in the sky. Lighter sleeping robes were, moreover, found to be adequate for night use in the summer season.

As a result of experience also we later devised tents much better adapted for our purpose than any that could be obtained from the manufacturers. The first summer we carried the light "hikelike" tents of a patented fabric. These were found to leak very badly even in the light rains which we encountered, and as the floors of the tents were paraffined, this water stood in puddles upon the floor. If one is supplied with a sleeping robe he does not need a tent, but only a mosquito-bar, so long as the weather is fair. There is, however, for bad weather the need of a waterproof shelter since the water-proof covers of sleeping bags are too heavy to include in packs. A one-man combined mosquito-bar and shelter tent was made with poles of bamboo, which weighs only three pounds, and proved to be entirely satisfactory on later expeditions. (See head-piece of chapter XIV, p. 154.) 
A somewhat better, though considerably heavier, two-man tent for use at the base was also constructed upon a very simple model and used with success on the last expedition. These tents were all made from light balloon silk and treated with paraffine, for our experience showed that almost the only satisfactory preparation for water-proofing a light-weight tent is paraffine. (See p. 128.)

For our meteorological and aerological equipment we carried aneroid barometer, swing psychrometer, hand anemometer, pilot balloons, calcium hydride for generating hydrogen, and a theodolite for combined aerological and surveying work. For studies of the snow on the ice-cap Professor Church carried his well-known though somewhat heavy snow sampler.

The ice-cap party consisted of Gould, Church, Belknap, and myself with four Eskimos of whom Abraham was both hunter and guide. Our arrangement with the Danish manager at Holstensborg had been that the four Eskimos should bring with them their food, as we were at the time unfamiliar with their usual rations. We were somewhat surprised by the small packs which they brought with them, and as all but one carried an antiquated type of rifle, it was assumed that we were to find game at least largely sufficient for 
their needs. For them a very small tent sufficed, since they slept curled up together like dogs without any blankets whatever. Before leaving our camp on the Maligiakfjord they shot several gulls and made a hearty meal of them.

In the late afternoon of July 25th David Olsen's little motor-sloop, the Kanotok, arrived off our camp, and as soon as he landed, our plans were made to get off on the flood tide early the next morning in tow of the Kanotok as far as the head of the fjord. Unfortunately we were an hour later than we had expected to get away, and Olsen was obliged to leave us far below the head of the fjord, from where we had to row hard against an ebb tide and fast shallowing water. This meant two and one half hours rowing in the umiak before we reached the first rapid in the river which flows to the fjord from Taserssuak. At these rapids there was a summer fishing camp of Eskimos and we were able to get help in portaging the heavy umiak past the rapids. When we had left these rapids behind we encountered others which gave us great difficulty, but by taking out some of the load and carrying out a combined towing, poling and paddling operation we by late afternoon were past the last rapid and able to make our camp near a fresh water stream which enters near the 
outlet of Taserssuak. We had not altogether escaped without accident and before setting out the next morning it was necessary to mend a leak where the umiak had been on the rocks.

After our supper our Eskimos got out their Bibles and Lutheran hymn books and lying curled up together in their minute tent, their voices blended musically in simple and familiar hymns, which as children we had learned but now for the first time heard sung in the Eskimo language. In their Lutheran Church schools the south Greenland Eskimos learn to write the Eskimo language with its curious characters. Abraham's son Nathaniel, who was one of our party, kept the diary. These younger Eskimos were as anxious to learn English as Gould and Belknap were to learn Eskimo. So after supper squatting on the ground one of our men would point to some object, such as a knife, and say "Greenland", meaning, "What is the Eskimo word for it?" The Eskimo word is pronounced and recorded phonetically in the notebook. Nathaniel then points to the same objects and says, "America", and Gould and Belknap at once give him the word "knife". This they set down as it sounds in their own Eskimo characters. Then the stadia rod is brought out and the figures upon it are used for learning the simple numbers by the 
same process. These lessons, which were repeated almost daily after supper, yielded chiefly the common substantives in both languages.

The next morning the Taserssuak, which means great lake, was quite placid and we were up by four o'clock for an early start. I had breakfast ready by five o'clock and the umiak was soon loaded and we were rowing up the lake. Straight ahead across the western arm of the lake we could see another stream passing through a canyon within a series of beautiful elevated beaches each of which was sharply outlined like a railroad embankment and the group together making a well defined staircase. These terraces formed in clay deposits are of a type quite generally to be found at the heads of fjords of Greenland and also in lakes like this one, which occupy a part of an earlier fjord. They revealed to us in unmistakable lines that after the fjord had been shaped by the glacial tongues which pushed out from the borders of $\Omega$ once much larger ice-cap, the continent sank until the sea flowed up the broad bottomed valleys, but later made a partial and interrupted recovery to the accompaniment of earthquakes, each of which has left its record in one of the steps of the staircase. It was at the foot of this series of elevated shorelines that Nordenskjöld's expedition made one of 
its camps in 1909, at which time caribou were so abundant within the district that this explorer was able to depend upon them for his food supply. Now they are rare and exceedingly shy, and though we frequently saw fresh footprints as we got nearer the ice-cap, we were not fortunate enough to get in sight of a single animal.

About us the Taserssuak shores rose on precipitous rocky slopes to heights of $\mathbf{1 3 0 0}$ to $\mathbf{1 7 0 0}$ feet and more, and were shaped in sharply angular contours which present much grandeur of scenery. What now was our surprise on turning to the south and passing through a gateway into the main portion of this great lake, to have open up before us as though by the magic wand of a magician, a wholly different country-one lacking the high relief but moulded in softened outlines. It was a passage from the majestic to the placid in landscape. The type of landscape which now opened before us was one which we were to continue to see about us until the margin of the inland-ice was reached. The landscape we had left behind us, however, extends outward to the coast. The explanation of this contrast could not escape one who is familiar with the sculpture that is accomplished by glaciers.

The ice-cap, which now has its front a full 
hundred miles back from the coast, was once advanced until it overwhelmed all the land and perhaps rested upon the sea. Later it retired to some line probably near its present front, thus leaving all the land in the condition of that which we now find along the coast; that is to say, with an average height today of about 1300 feet, with somewhat sharp contours, and now so altered by weathering that none of the glacial scorings which the ice left behind can be made out, though weathered boulders are to be found in profusion on all high levels. Now at a much more recent time the icecap once more waxed large, pushed its front out as far as the gateway of Taserssuak, but only to retire still later to its present position, thus leaving the land only about two-thirds as high as in the coastal zone and remoulded in softened outlines by the glacial sculpture of this later glaciation. This retirement has been so recent that the fine scorings upon the rock and the wonderful glacial polish are everywhere to be seen.

We row laboriously against a stiff wind, keeping to the southern shore and at mid-day go ashore for luncheon. Here we make our first real acquaintance with the luscious Greenland blueberries on minute plants which push up hardly two inches in the tundra, but which are widely distributed and 
made an agreeable dessert to many of our meals on this expedition.

Later in the day the wind veered to the west and blew strongly down the lake, so that we hoisted sail and, sprawled on the load, now without effort we glided rapidly up the lake. From this position we could study the very remarkable cirrus clouds which here present perhaps a greater beauty and variety than anywhere else in the world. At the head of the lake, where we arrived in the late afternoon we made a cache of the heavy umiak and occupied another of Nordenskjöld's camps, but one where the weathered antlers of caribou are already deep down in the tundra to testify to an earlier camp of caribou hunters probably at least fifty years before.

With the umiak now left behind, we set out on July 28th to carry everything upon our shoulders, our strong man Gould portaging the seventy-five pound canoe. From lamed muscles and the protests of our Eskimos we had learned before noon that we must further reduce our loads. We had left a large cache of provisions under the umiak for use upon the return while making surveys about Taserssuak, but we must now adopt a simpler fare and so secure a lighter outfit. At our next camp, a dry one, we therefore left a depot, but still 


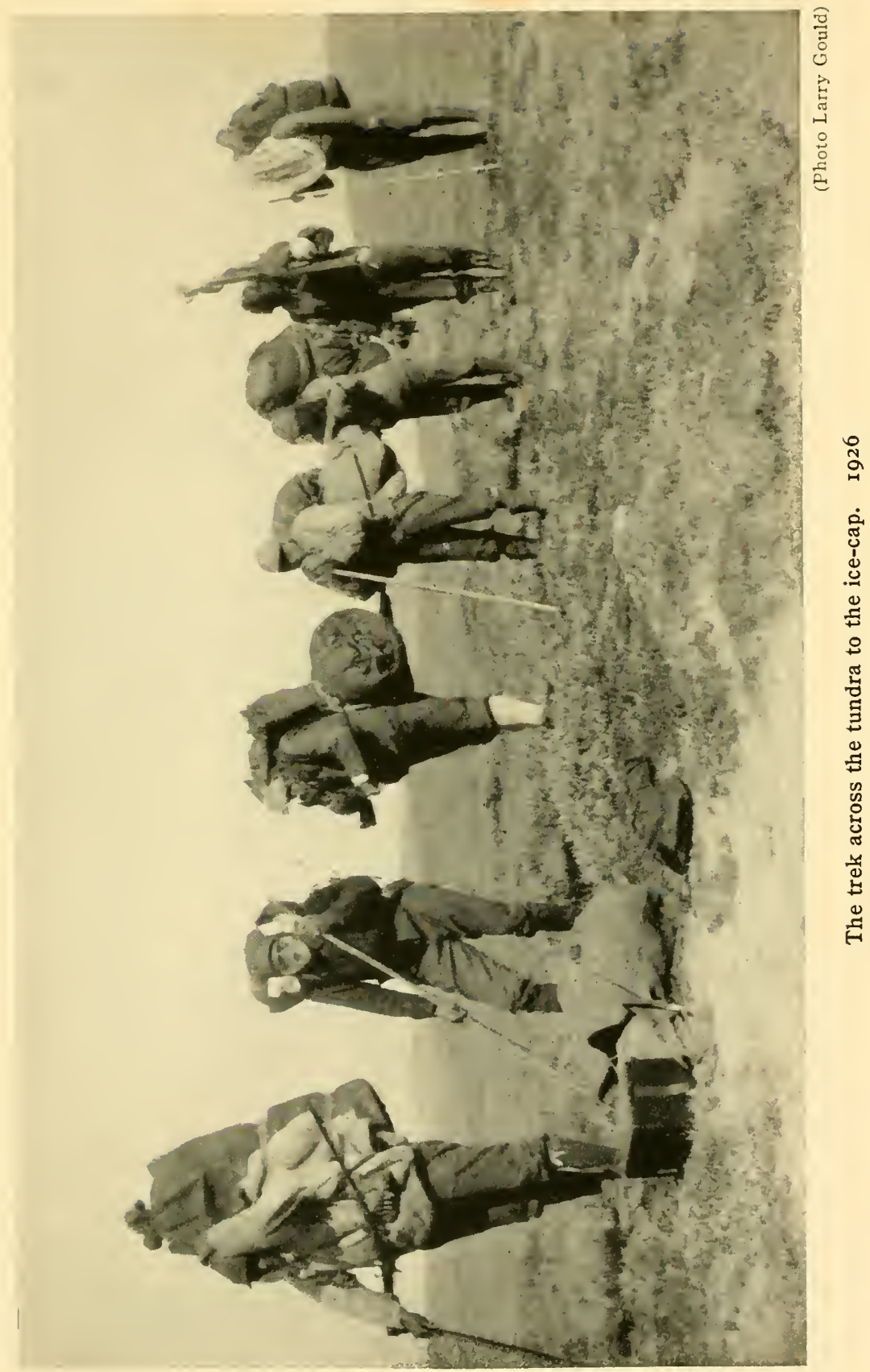



found it necessary to relay two of the packs. It testifies to the abundance of potable water in Greenland except along the fjords that this camp was the only dry one we were to make on the entire journey of 21 days, and we did not find it necessary to carry water with us when on trek.

The Eskimos were much surprised to see Larry Gould take the canoe upon his shoulders and march off with it, but we were hardly less surprised to observe the heavy packs which they were able to carry. All of us were so loaded down that we staggered when getting up, but once started we soon got accustomed to the burden and after a little found pleasure in the daily trek.

The first day had been a very trying one and I did not call the party for breakfast the next morning until near eight o'clock. The breakfast I always prepared myself as this permitted me to fix the time of getting off. The next night we camped above a waterfall at the edge of a lake and were thus assured that we would be able to use the canoe on the morrow. Early the next morning Gould and Belknap started up the lake in the canoe toward a high mountain visible at the further end, with instructions to climb it and strive to gain some idea as to available lakes for the canoe on the 
route ahead. With relatively light packs the rest of us under Abraham's lead took to the trail.

When we of this trekking party had reached the head of the lake we climbed a point rising to about 1,000 feet altitude and were able to make out something of the country east of us and a considerable stretch of the inland-ice far in the distance. Church and $I$ then made camp and prepared a supper of erbswurst and tea, keeping the soup hot for the others, who might come in at any time or might be late, since their mission was a very important one. I was now to have another proof that a little knowledge is a dangerous thing. To Abraham I attempted to explain in pantomime that $I$ had sent Gould and Belknap out to find a good path, making use of the Eskimo word for path or trail. Alas! He misunderstood me. He brought out his antiquated spy glass which he pronounced "no good", and having obtained my binoculars he rushed off on the trail. I called him back, for it was now clear that he thought I considered Gould and Belknap lost and that I wanted him to find them.

On the next day, the thirtieth of July and the fifth day of the expedition, Gould and I took the canoe down the lake to bring up another cargo, after which we set out toward the chain of lakes 
which Gould and Belknap had discovered in advance of us. On the thirty-first we made camp on one of these which I named Lake Offield, and Gould and I in the empty canoe set off up the lake to pioneer, for we understood Abraham to say that the course ahead was "no good" for a canoe. We found conditions excellent and were still able to use the canoe to great advantage for a considerable distance. In all the canoe was portaged a distance of sixteen miles on the double journey, and it saved us the transport of nearly five hundred pounds for a distance of about seventy-five miles.

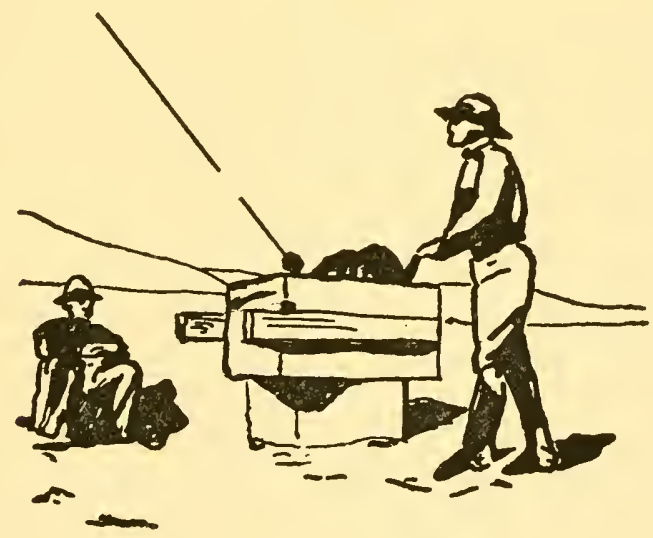




\section{CHAPTER VII}

THE RETURN ON FORCED MARCHES

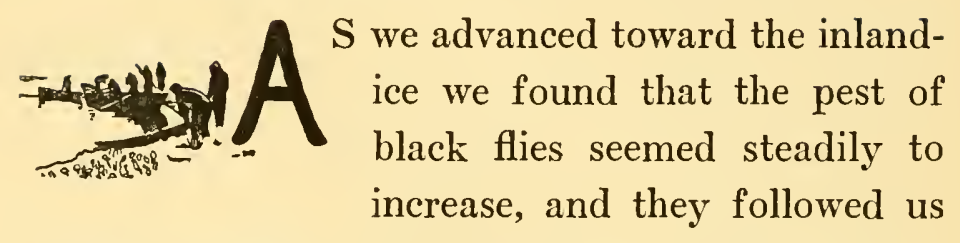
to the very edge of the ice-cap itself. On the thirtyfirst of July when we opened our food bag for luncheon, we discovered that the bag of salt had been left insecurely fastened and its contents were distributed with the other food and with some debris in the bottom of the food bag. We made a virtue of necessity and passed the material from the bottom of the bag through the tea strainer with at least moderate success.

The night was cloudy and cold, almost the only break in the beautiful weather which we had had throughout. On the first of August Peter and Nat were sent back on the trail to bring up packs 


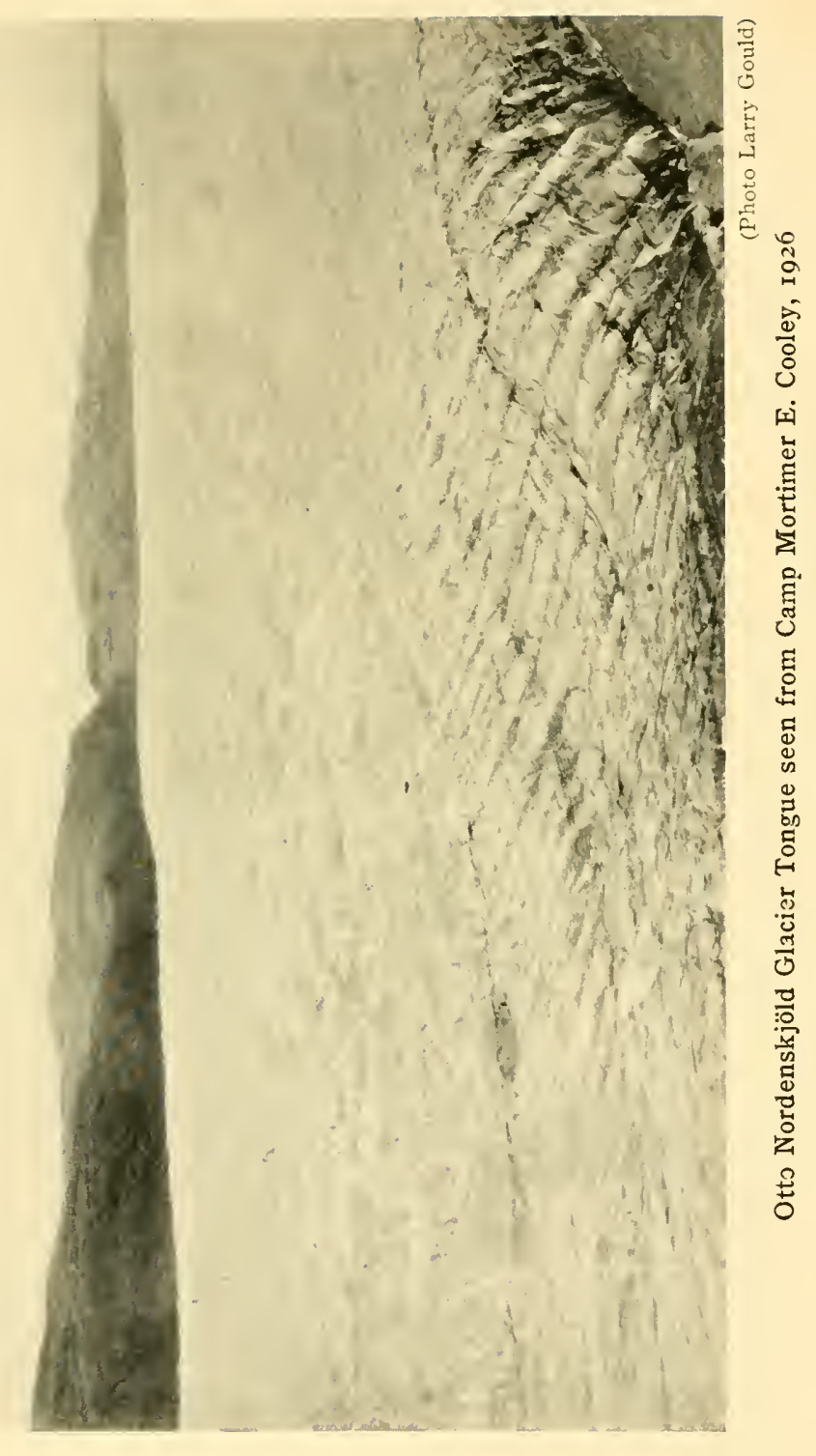



left behind; Abraham, Enok and I went ahead on the trail; while Gould and Belknap with the canoe started up the lake beside which we had camped. Our trekking party lost its way, and to get back we had to make a wide detour in country with many small lakes and knob-like hills which interfered seriously with the views ahead. When we at last arrived at the upper end of the lake, Gould and Belknap were in with the loaded canoe. We set up our tents at an old caribou hunter's camp while the canoe was sent down the lake for the last load, which was in by six o'clock.

The strain of the strenuous trekking was now beginning to tell upon us. Abraham's legs showed indications of giving out, Nathaniel and Peter have bad blisters on the soles of their feet and are under treatment by Gould, Enok has strained his knee in an attempt made, contrary to my wishes, to carry two packs in one and so avoid a relay. We are, however, nearing the ice-front, and on August 2nd, the eighth day out from our base, I am able on my pioneering trip to look down from a nearby ridge upon a tongue of the great inland-ice. In honor of the explorer who reached it in advance of us, I give it the name of Otto Nordenskjöld Glacier. In two more days we should be able to reach the edge of this glacier. 


\section{NORTH POLE OF THE WINDS}

As we start out the next morning Abraham and Nathaniel are both largely incapacitated, but the latter is able to carry a light load. For the last three nights the air has been much colder, and this morning we find the water frozen in our water pails. We now observe a certain twilight around the midnight hour. Abraham has seen fresh tracks of a caribou and our hopes are aroused that we can add fresh meat to our larder and relieve the strain upon it. We have shot a few ducks and have seen some flocks of geese, but the geese are shy and all our efforts to bag them have been futile.

We now decide to go forward with reduced loads, make camp at the ice-front, and then send the Eskimos to bring up the rest of our duffle while we carry out balloon ascents at the margin of the ice. A very serious situation is developing; our Eskimos have now completely exhausted their meager food supply, for they had trusted to get game and especially caribou, but to our great disappointment we have not seen one.

On the evening of August fourth we made our camp close beside and overlooking the Nordenskjöld Glacier tongue. This camp we named Camp Mortimer E. Cooley after the distinguished head of the College of Engineering at the University of Michigan and a warm friend of our enterprise. 


\section{THE RETURN ON FORCED MARCHES}

The next morning early Abraham is sent off to hunt caribou. The other Greenlanders who are able to travel, Peter and Enok, go back for packs which had been left behind, and we begin our balloon studies. These ascents which we carried out were successful, and were the first ever to be made so close to the inland-ice either in the Arctic or the Antarctic. The courses followed by the balloons showed plainly the structure of the ice-cap air circulation. The balloons rose first passing off to the northwest under the influence of the outblowing winds from the ice-cap, and then at about twelve hundred meters elevation, or about threefourths of a mile, they reversed direction and, boomerang fashion, passed in over the ice.

At night Abraham returned discouraged, for he had not seen even a trace of caribou. Our condition is not a pleasant one. We have now reached the ice-front only to find that we must feed eight men with the rations we had planned for four, even though for some days we have been keeping the rations too low for such heavy work as we are doing. Only one course is open to us. We must cut down the time for our ice-cap work to not more than four days at the most, after which it will be necessary to start back to our base on forced marches and with half rations until our nearest 


\section{NORTH POLE OF THE WINDS}

depot is reached. This nearest food supply is at the dry camp between Taserssuak and the waterfall.

The next morning we set off under heavy packs to go in over the ice-cap. Under Abraham's guidance a place is found on the margin of the Nordenskjöld Glacier where by cutting steps with our ice axes we are able to ascend onto the ice surface, which is here very rough. Deep crevasses go down into the blue depths of the ice and a system of thaw-water channels averaging twenty-five feet in depth completely cover the surface leaving only sharpened ridges between. The wind is blowing hard off the ice, and though we are protected when in the trenches, our heads and especially our broad packs are caught suddenly in a twenty-mile wind so soon as they appear above the crest of the ice ridges. Under these conditions it is especially difficult to keep one's balance even though we are shod with crampons or climbing irons. On one occasion Church and I lost balance at the same moment and with our heavy packs rolled together into the wet bottom of the valley below.

In spite of our best efforts we are able to make but little advance over the ice, and finding no suitable place to camp, we decide to return to Camp 
Cooley and start out the next morning with much lighter loads.

Abraham's hunting has yielded no large game but only a single small ptarmigan. If we could now secure a good sized caribou the situation would be relieved at once. Fuel is very scarce and we now begin the regular use of the primus lamp.

The twenty-mile wind off the ice during the day had not been cold, quite the contrary. The temperature of the air as determined by the swung thermometer was $52^{\circ} \mathbf{F}$. This is the well-known warm foeln effect of down-slope winds wherever found, and the Greenland type of foeln cloud had been in view in its dark mushroom shapes over the ice to the southwest. One good effect of this wind has been to blow away the black flies which had disappeared temporarily from Camp Cooley.

This morning a fat Arctic hare hopped right into our camp and was shot by Abraham. While his body was still warm he was dropped into the pot and soon afterward devoured by our hungry retainers.

The next morning we made a fresh start and entered the ice-cap from a new position farther up the glacier. As the wind had now died down considerably we made much better progress and advanced sufficiently to carry out our pilot balloon 
ascents. Abundant water for the hydrogen gasometer was obtained from the brooks which everywhere coursed over the glacier surface.

The results of these ascents were much the same as those obtained from the ice margin at Camp Cooley. They demonstrated clearly the characteristic structure of the glacial anticyclone-the downslope out-blowing winds near the surface and the inward-blowing winds at a higher level.

From our advanced position upon the glacier it was now a long way back to Camp Cooley and we reached there late at night very hungry and nearly done up. Church has been suffering from loss of sleep, for without any assistance he has maintained a regular three-hourly series of meteorological observations throughout day and night, and in addition to this he has taken part in all our treks over the ice.

On the night of August 8th I awoke to find a few drops of rain falling on my face. This was interesting as the first rain we had experienced in the thirteen days since leaving our base on the Maligiakfjord. The days had been warm and dry and the skies clear, so that the climate so far as we had experienced it would be described as semiarid. That the prevailing winds in this district blow off the ice is confirmed by the habit of the low 
shrubs-birch and willow-which grow in the vicinity of the ice margin. Their branches rest upon the ground and are spread out in a fan on the side away from the ice-cap.

Abraham is still unable to secure any game and it is now decided to start back to the base without any further delay. Kerosene, rope, furs, ice axes, ammunition and other equipment which would not be needed until the following year, are deposited under a sloping rock at Camp Cooley and carefully walled in, after which we set out the same afternoon on the back trail. The blistered feet of Peter and Nat are no longer very troublesome, Abraham's legs have had some rest, since he has carried no pack when hunting, but Enok's knee is still in such condition that he must start out with a light load. Church is still very tired and I have sprained an ankle which is giving me trouble. We are now regularly rationing the Eskimos, but I find it best to dispense food to them at each meal. The Eskimos with all their excellent qualities are not a provident people, and it was soon found that whatever food was given out was eaten up at once.

With some difficulty we are now able to manage our loads without relays, and after the first day Enok's knee is so far improved that he is able to take on a full pack. On August 9th we reached 


\section{NORTH POLE OF THE WINDS}

Lake Emmons, and on the tenth by a forced march at mid-day we arrired at the canoe, and with all our material on board Larry and Belknap set off down the lake while we without packs trekked along the shore. Before setting out on the 11th we had eaten the last of our biscuits, but we had still sufficient food on the half rations we hare maintained to reach our camp abore the waterfall, which is only three miles abore the dry camp where our nearest store of prorisions is cached. We are left with something less than two pounds of food per man but could afford to be generous with our dinner, though I felt that we had cut our rations to the limit to proride for contingencies. Tired as he is, Belknap, who does not relish the erbswurst, rolunteers to go to the cache and bring in a rariety of other food for our erening meal.

Once more near our food supplies the return journey proceeds without notable incident and we arrive at our base on the Maligiakfjord twentyone dars after setting out.

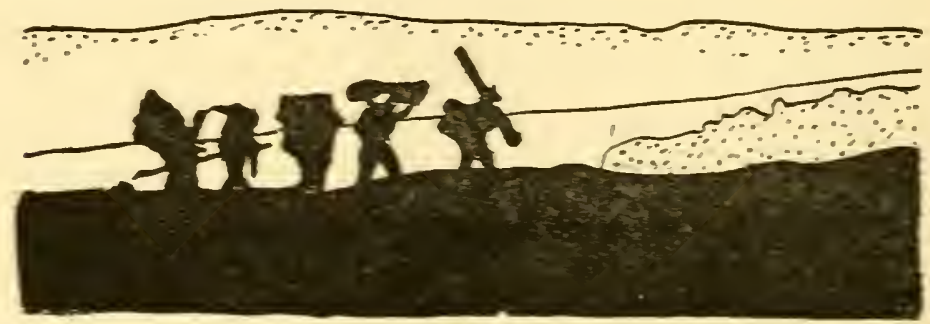




\section{CHAPTER VIII}

AGAIN IN CAMP ON THE MALIGIAKFJORD

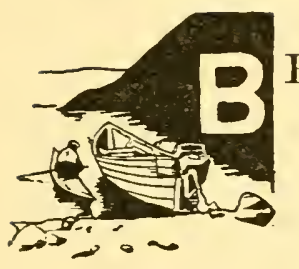

ECAUSE of our failure to secure caribou and the shortage in our food supplies, we had returned to the base on the Maligiakfjord

a full ten days earlier than expected. We were met by startling news. The day following our departure our radio had picked up a call from the Morrissey which was high and dry on an uncharted reef near Northumberland Island in latitude $77^{\circ}$ North. Fortunately this call was also picked up by Captain MacMillan on the Sachem, which was at anchor in the harbor of Sukkertoppen a hundred and fifty miles farther down the coast, and by exceptional good luck the small revenue vessel Islandsh $F$ alk was at the time in the same harbor. On receiving the news the Islandsh Falk had at once started north to 
the rescue, but of course without learning whether the Morrissey had been able to get off the reef. On reaching Holstensborg Governor Bistrup advised delay until his motor-schooner $W$ alrus could go in to our camp and learn from us whether we had received by radio any later information.

From his intercepted messages Oscanyan was able to advise the Governor that the Morrissey had got off the reef shortly after midnight on the 22nd. His message had read, "Afloat and pumps have water under control. We are bound for $U$ pernivik and are off Cape York.-Putnam." With this information the Captain of the Islandsk Falk set his course for Upernivik where the Morrissey arrived and was beached for repairs, after a difficult passage, in which the pumps were kept going almost continuously. With the aid of a diving suit carried on the Islandsk Falk the larger openings in the hull of the Morrissey were closed so that she was able to proceed.

It was only later that this news reached us at the camp on the Maligiakfjord, after we had much time to reflect upon how we should get back to civilization if the Morrissey should be wrecked or was seriously disabled. The last vessel to return to Copenhagen before the season closed would leave Holstensborg about the time when we had expected 
the arrival of the Morrissey. We gave ourselves over to our scientific work and to surveys in the vicinity which were in charge of Belknap.

While we had been away on our journey to the ice-cap the weather at our base had been much more rainy than any we had encountered in the hinterland. Notwithstanding this, Fergusson had made nearly sixty balloon ascents, on fair days sending up both morning and afternoon balloons. Our little radio station had been able to pick up 137 stations scattered widely through Europe, North America, South America, Australia, and New Zealand. One night a call came from a distant station in the heart of West Central Africa. When Oscanyan gave his station as that of the Hobbs Greenland Expedition, the reply was, "We've heard a lot about you".

As August drew to a close the signs of the coming winter season became daily more apparent. The few birds about camp one after another left us. There was in the night an ever deepening and lengthening twilight around midnight, until we could faintly discern a few stars of the first magnitude. We awoke on the morning of the 21st to find snow covering the hills across the fjord, and later in the day we were ourselves in a flurry of snow followed by a rain of sleet. 
On August 25th came a message from the Morrissey, which was then at Jones Sound near South Ellesmere Land. The Morrissey, reported Mr. Putnam, would be at Holstensborg early in September, which was in advance of our pre-arranged schedule for the 18th. He promised to give us a more definite date very soon, for it was of the utmost importance that we should know some days in advance in order to take the expedition out to the coast before his arrival. By a stroke of good luck on the day after Putnam's message had come through, David Olsen's motorsloop Kanotok hove in sight and soon came to anchor off our camp. We were thus able to make immediate arrangements for Eskimos in kayaks to come in from Sarfanguak and act as messengers when notice of a definite date should come from the Morrissey, and we could now engage Olsen to take the Expedition down to the coast.

Kayakers actually came in on the 27th and on the 29th, on which latter date we held them in camp as we were expecting a message daily. On September 1st the Morrissey was in Pond's Inlet in latitude $73^{\circ}$ North, and sent us a message promising definite date within forty-eight hours. Soon thereafter she was at sea and sent the message, "Unless advised contrary will call for you on the 5th". A 
note was at once sent off by kayaker to Olsen that we would be ready to embark at noon on the 3rd and that he was to try to get us down to the coast by noon of the 4 th; for it was realized that the Morrisscy might make better time than expected and we meant that no delay should occur upon our account. On the other hand, the ship might be delayed, and so we took with us a full camping outfit with supplies and provisions prepared to make our camp near Holstensborg and remain there for as long a time as might be necessary.

Looking forward to the expedition of the following year we arranged for Abraham, our Eskimo guide, to take provisions and equipment in to Camp Cooley by dog-sled during the ensuing winter when transportation is usually a much simpler proposition. With everything snug at our camp we embarked for the coast on Olsen's sloop on the morning of the 3rd. We stopped for luncheon at the little Eskimo settlement of Sarfanguak where Olsen is manager. The sharks which had lain in rows on the miniature beach at the time of our first visit on July 7, were now an unsavory mass of rotting flesh which filled the air with an unbearable stench, but on which the dogs of the little settlement were making a savory meal. A shark freshly caught on a heavy set line was teth- 
ered to the dock and was darting about. This he would continue to do until starved and exhausted, when he would be hauled in and added to the display along the shore.

After we had set off in the afternoon the wind rose, and as we approached the widened opening of the fjord toward the sea, it became very rough and the more susceptible of our party were made seasick. Arriving at the coast in the evening we set up our camp just outside the colony of Holstensborg after being most hospitably received by the Governor and Mrs. Bistrup.

On the 5th we were in a foehn wind from the ice-cap such as we had first become acquainted with when at Camp Cooley on the border of the ice. Here, however, the wind was accompanied by considerable rain, most of which seemed to pass through our tanalite tents. All night the tents flapped as the wind tugged at them and threatened to pull them loose from the heavy boulders by which they were anchored. Each flap of the canvas sent down a shower of water, so that we were soon drenched even in our sleeping bags.

In the early morning we were cheered by the arrival of an Eskimo who reported that the Morrissey had come in during the night and was already at anchor in the harbor. At the same time 
the sun came out after the rain and we were soon getting out our wet bedding to dry while breakfast was being made ready over our primus lamp. Soon our shipmates of the Morrissey were ashore and coming up the path toward the Governor's house led by Mr. Putnam and Dr. Knud Rasmussen, the distinguished Danish Arctic Explorer who was returning from the North on the Morrissey.

Dr. Rasmussen was born at Jakobshavn in North Greenland, the son of the Danish pastor and his Eskimo wife. His remarkable achievements have stirred the pride of the Eskimo people, as his efforts to improve their conditions have aroused their grateful appreciation. It was pleasant to observe the respect approaching adoration which all the Eskimos of the village showed toward this remarkable man. In 1913 he had carried out a double crossing of North Greenland, in 1917 he had made a remarkable sled journey along the Greenland north coast, and he had lately returned from what was probably his greatest achievement, the four-year long crossing of Arctic America. The Eskimo trading station at North Star Bay in the Cape York district was planned and is now kept up by him. 'The Morrissey had taken north to this station a supply of stores and was now bringing back to New York a large consignment of 
blue fox skins to be sold for the benefit of this far northern colony of pure Eskimos.

On board the Morrissey were two husky polar bear cubs, and the necessity of making repairs to the engines and of building from stout planking a suitable cage for the bears, would delay our departure until the afternoon of the 7th. At Mr. Putnam's suggestion we remained in our camp for another day, but were kept busy getting a large part of our stores put away in one of the storehouses near the dock. In her disabled condition and with a large supply of partly fleshed walrus and other large game specimens on board, there was hardly room on the Morrissey for the twentysix men and two bears which together made up the personnel for the return journey to North Sydney.

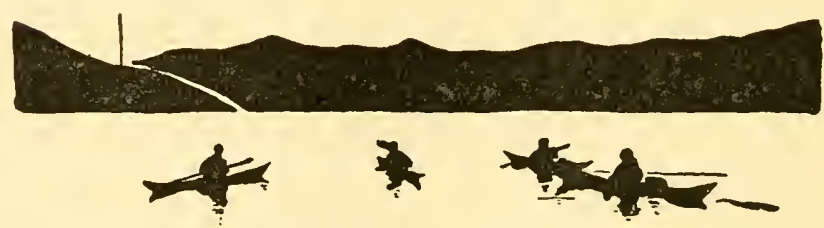




\section{CHAPTER IX}

THE STORMY RETURN CRUISE ON THE CRIPPLED MORRISSEY

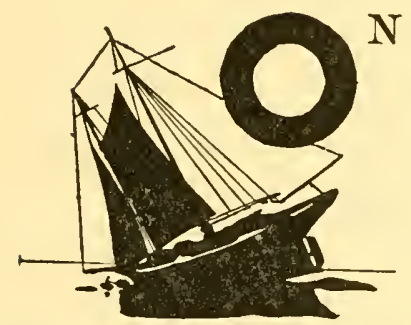

the afternoon of September $\boldsymbol{7}$ the motor of the Morrissey had been overhauled by Peary, and under Dunrud's direction the bear cage had been set up on the forward deck near the foremast. At three o'clock the anchor was weighed and with Governor Bistrup and his family waving good-bye from his launch and dipping the Danish colors, the Morrissey pointed her prow out to sea.

As we were moving down the little harbor there occurred a most unusual incident in the history of this out-of-the way post. A Norwegian ship evidently in distress came limping in just before we 
passed out. We were later to learn of the tragic experience of this disabled vessel. Held for a time at Holstensborg, at the first opportunity its condition was reported in Norway and a ship sent out from there to tow the disabled vessel home. The cruise started well, but later in bad weather the tow-line parted and the ship was swept away and lost, the crew, however, being saved.

With her false keel gone the Morrissey was unable to nose into the wind and quite unable to tack when the wind was ahead. Facing the wind it would be necessary to wear the ship and resort to the dangerous expedient of jibing. Our reliance had therefore to be placed upon the engine whenever we should encounter a head wind. On the evening of the eighth, hardly more than a day after leaving port, a game of cards was in progress in the midships cabin, and Peary, who was sitting in the game, rather suddenly stopped in order to listen to the revolutions of his motor in the neighboring engine room, since it seemed to be slowing up. He turned to me and asked for my watch so that he might count the revolutions. Apparently satisfied, he resumed his game, but almost immediately jumped up and rushed to the engine room and jammed down the throttle to the motor. Our screw and a portion of the shaft had 


\section{THE STORMY RETURN CRUISE}

gone to the bottom and the motor in consequence had been racing hard. We were now at the mercy of the wind. Peary soon came back and quietly took up his hand in the game as though nothing had happened.

There were other serious sides of this accident. Our supply of water was quite limited and Captain Bob at once issued orders that the amount of water for each washing must be strictly limited to a small cupful.

Before breakfast next morning all hands were called on deck to hoist the mainsail in a light northerly wind. Our course is set to the southwest toward the coast of Labrador, where during the month of September the winds are prevailingly westerly. With winds off shore it should be possible for us to make headway in our crippled condition.

Two days after the propeller was lost we ran into a full gale, and the barometer dropped from 30.01 to 29.36 inches. Seas came aboard and several of us received duckings when going up the forecastle gangway. 'Two of the crew, Jim and Ralph, had to jump into the shrouds to escape a particularly heavy sea. Church was thrown down near the pantry and received a cut on his head. Toward morning of the eleventh of September the storm 
was at its worst and the whole pantry of dishes was upset with a crash. Boxes and bags of duffle went rolling or sliding about in the midships cabin and everyone was rendered uncomfortable. We were under a storm trysail and jibs, but by night the gale had fallen off somewhat though the sea was still running high. We were among icebergs and it was raining and disagreeable, so that those who were not needed on deck kept to the cabin. Every two hours two men must man the pumps to keep down the water which is constantly seeping through the seams into the hold. The deck was badly strained when the ship struck the reef, and now that it is raining a mixture of sea-water and walrus blood is continually dripping down into the bunks of Fergusson and Manly. My own bunk on the other side of the cabin is badly splintered, but fortunately does not leak. With considerable satisfaction the skipper informs us that the gale has not noticeably strained the ship and that the water which comes into the hold has not appreciably increased. According to Will Bartlett, the mate, we are now off the Labrador coast about 175 miles south of Cape Chidley.

On Sunday, the twelfth, the wind fell off sufficiently so that we hoisted both the mainsail and the foresail. For some reason the odor of the 
partly fleshed walrus coming in to our cabin from the engine room was especially heavy this morning. Toward night the wind freshened and we were able to make a speed of seven knots without counting the current which was setting strongly with us and the wind following. With the falling off of the wind in the morning our seasick members, particularly Gould and Fergusson, had been able to come on deck. We had managed to get out for them some cans of delicious grapefruit which they were able to eat with relish. At Holstensborg the Morrissey had taken on a supply of fresh halibut, but a staple article on our bill of fare was polar bear steak cut from quarters which are hanging in the rigging. This meat is coarse grained and tough and it lacks the juiciness and delicate flavor of caribou meat, which we later learned to regard as the meat par excellence, whether served in steaks or as a roast.

On the thirteenth with a light wind the sun made its appearance and our invalids were again able to come on deck. Captain Bob made a noon observation of the sun and found that we were off Turnavik in Northern Labrador. Though it is pleasant to warm ourselves in the sun we were sorry to lose the wind which was helping us on our way. Many fine icebergs were now in sight 


\section{NORTH POLE OF THE WINDS}

and deep down in the water we could see many jelly-fish, which are by no means rare in these cold waters.

On the fourteenth we were off Cape Harrison. The wind had now stiffened again and we were soon racing along at an eleven knot gait with the wind on the starboard beam. Had this wind held we should have been at Belle Isle the following night.

About the middle of the night we were awakened by a great shock to the ship which members of the Putnam Party said was equal to the shock felt when the Morrissey went on the reef near Northumberland Island. Old Tom, who was at the helm, had let the ship wear until the mainsail had gone over in a jibe nearly taking out the masts. Next morning the wind died away again and was off the land. These frequent changes have meant for us much making and shortening of sail. We are now approaching the straits, but in our crippled condition we require an east wind in order to enter them. On the night of the fourteenth few of us were able to sleep. The radio seemed to be particularly noisy and brought about acrimonious remarks from the would-be sleepers. About two o'clock one of the crew executed a double shuffle on the deck over our heads and "Art" Young 
with fire in his eyes tumbled out of his bunk and started up on deck to razz the disturber of our rest.

On the fifteenth the sea lay smooth under a sunny sky with icebergs visible in every direction. In our helpless condition it was evident to us that we might drift in such a sea for a long time, and so the captain has now prohibited altogether the use of water for ablution. The order first went out in the after-cabin, and Rasmussen, whose bunk is there, slyly came into our midships cabin for a shave but was caught in the act by the skipper.

We managed with some difficulty to get into the straits, but only to be caught by a half gale dead ahead accompanied by a heavy sea and a bad tide. As the straits are here barely nine miles in width and the wind almost exactly dead ahead, we were forced to sail in the trough first toward one shore, where we would wear the ship, jibe and with wind on the opposite beam sail to the other shore, where this dangerous operation would be repeated. The ship received fearful jolts at each reversal and no headway whatever was made.

For three long days in succession we kept up this useless but necessary operation, all the time within the area off Point L'Amour. Throughout this trying experience the skipper was almost constantly 101 
on deck, but on the third day, thoroughly tired out, he put in at the fishing hamlet of L'Anse au Loup on the Labrador shore where there is an open roadstead with the wind at the time blowing off the land. Here the Morrissey came to anchor and all went ashore to stretch their legs. The little settlement consisted of a single line of twenty-two houses stretched along the narrow beach behind the rude tables or "flakes" where the catch of cod was spread out to dry in the sun. We had luncheon ashore, after which Captain Bob stretched himself out on a sofa and was soon sound asleep. Parties were made up and went out in various directions to explore the neighborhood. With Fergusson as my companion I soon found myself on a rocky ridge not far from the settlement, where before very long I observed the wind within a few moments swing through an angle of nearly 180 degrees and blow freshly inshore. Together we rushed down to the shore and found the skipper asleep in the telegraph office. He was considerably alarmed and we soon made our way out to the ship to make ready for sailing. Grould, Belknap and Oscanyan passed near us in a boat and the skipper hailing them got them to go on board at once. Church was already there so that the Michigan contingent was accounted for. Five of 


\section{THE STORMY RETURN CRUISE}

Putnam's party were, however, still on shore and Putnam with Peary started ashore to find them. It was a full hour, however, before all were on board, and the Captain several times expressed his fear that we should not be able to get off before dark. As soon as all were aboard there was great haste in getting up the anchor and making sail, but not long after we had got under way the wind fell off and before morning was in its old quarter and we were once more in heavy seas wearing the ship and jibing, which racked the ship terribly. At breakfast the Captain remarked that he had "Almost lost his sticks during the night"; and he added, "If any of you are on intimate terms with the Almighty, get busy".

The wind was still blowing a half to a moderate gale out of the southwest and Peary, now that he has no motors to care for has taken his trick at the wheel with the sailors. Brought up as he has been on small ships and with his great strength and endurance, he is now the Captain's right hand man. As he comes down to breakfast after a hard watch at the wheel the skipper remarked, "Robert, you're a true chip of the old block". There could be no higher praise from our skipper whose attitude toward his old leader, Admiral Peary, amounted to adoration. 
On the twentieth we are still held tight in the jaws of the straits though this is the thirteenth day out of Holstensborg. We are making perhaps a little headway, though very little. At midnight on the twenty-first there was great commotion on deck. The head wind which had so long held us in irons had fallen off and in a near calm the foresail was flapping and the traveller going over with a bang, first on the port and then on the starboard side. This calm was soon followed by a full gale in the northeast and we were running all night before it.

When I emerged from the forecastle gangway in the early morning the sight which met my eyes was one I shall not soon forget. The Captain was at the wheel, his sou'wester gone and strands of his long thin hair flying free. The great billows of a following sea reared their black masses far above the taffrail, but just before they broke the good ship would seem to slip out from under, so that only perhaps a foot of the heavy seas would come aboard and sweep about the Captain's legs. The bowsprit was dipping into the seas but with our canvas shortened to a riding sail and a jumbo jib, the ship was making eight knots. Riding out the seas, Captain Bob was in his element like a Viking of the olden times. How I have 


\section{THE STORMY RETURN CRUISE}

since blamed myself that I did nothing to preserve this scene in a moving picture. My excuse must be that Gould, our movie man, was seasick, and the camera stowed away somewhere behind him in the recesses of his bunk. Later in the day after the seas had quieted considerably, Kellerman, the experienced Pathé operator in the Putnam party, got some wonderful pictures, but they were not what we might have had in the early morning.

But we were in danger of swamping from this following sea, and the jib must come down, but at least the spell that has held us for the last six days seems now to have been broken. Now the wind is behind us and we are already out of the tight jaws of the straits.

The night of the twenty-second which followed was a wild one. After I was in my bunk the call came down for some hands to help take in the foresail which had been raised during the day. It was already dark and thick and rain was falling. Several were already up and Gould soon replaced Church who had been using his oilskins. Seas swept the deck and the operation was exceedingly difficult and dangerous but was finally accomplished.

There was not much sleep during the night at least in our cabin. The hatches had been battened 
down and the stench from the walrus carcasses in the neighboring engine room was almost overpowering. The mixture of bilge water and walrus blood which dripped into our cabins extended to other bunks. Peary took Raven's bunk in the after cabin while Raven was on watch and David crept into the bunk with his father. Kellerman's bunk was over mine and his heavy duffle bag hung on a hook beside the bunk. I would watch this bag as it swung far out into the cabin each time the ship rolled over to starboard and nearly went on her beam ends. Before morning the wind abated somewhat, and at six o'clock Peary came down to call all hands on deck to hoist the foresail, which had been got down with such difficulty the evening before. Coming on deck we found the sea considerably quieter and were much cheered to learn that with this following wind we might be able to reach North Sydney by nightfall. The gloom of the night before had passed and the spiritual barometer was rising fast.

In the afternoon we were able to make out in the distance the harbor of Sydney and shortly after dark we sailed into port from a relatively quiet sea. The voyage had lasted sixteen days and on getting ashore next morning we learned of the West India hurricane which had just destroyed Miami, Florida, 


\section{THE STORMY RETURN CRUISE}

and had then moved up the coast accompanied by the disturbances which we had passed through. Old Nova Scotia sailors reported it the worst storm off this coast for thirty years. We were fortunate to come through safely and we realized our debt to our skipper, Captain Bob Bartlett. For days on end he had been on watch catching a cat nap now and then lying on the deck. While in the straits of Belle Isle he had been in constant fear that the masts would go out when jibing. The Morrissey went into dry dock before proceeding to New York.

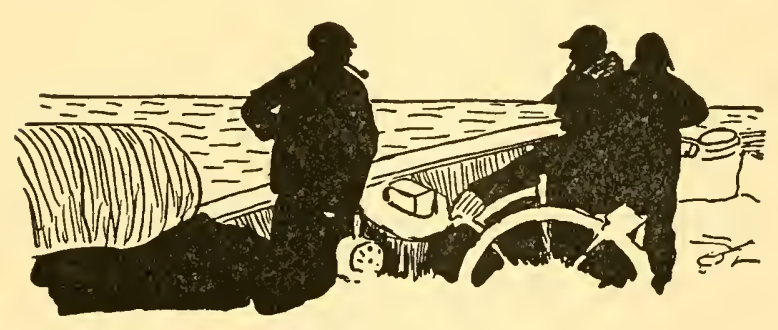




\section{CHAPTER $\mathrm{X}$}

THE SECOND EXPEDITION TO GREENLAND ON THE DISKO

HE expedition of 1926 had
reached Greenland directly,
due to the fortunate circum-
stance that the Morrissey had been chartered for the expedition of the American Museum of Natural History and Mr. Putnam had offered to take us along as passengers. This arrangement could not be repeated, and after various attempts had been made to travel by the Beothic chartered by the Canadian Government to carry supplies to the stations of the Canadian Mounted Police in Baffin and Ellesmere Lands, and by the chartered boats of the Pennsylvania Salt Company which bring cryolite from Ivigtut to Philadelphia, it was found necessary to fall back upon the small Danish Government ressels which ply between Copenhagen and the southwest Greenland coast several times each season. These boats are old 


\section{THE SECOND EXPEDITION}

wooden vessels of from 500 to 800 tons burden, but with the season of 1927 a new 1400 ton motorship, the Disko, was to be placed in commission and make Holstensborg a port of call.

Arrangements were therefore made to take the expedition of 1927 to Copenhagen and proceed from there to Holstensborg on the Disko scheduled to depart on her second cruise on or about May 28 th. Since we were to establish an aerological station for summer and winter alike, it was necessary to lay our plans with much thoroughness, and everything needed for the entire year had to be taken with us, including the lumber for the station.

As originally planned Peter Freuchen, veteran Danish Greenland Explorer who had been a member of Rasmussen's Thule expeditions, was to occupy a secondary observing station on the inlandice during the winter. This would permit of a valuable comparison with the main station. This arrangement had been given up for the reason that shortly before we set out Freuchen had to submit to the amputation of a portion of his left foot, which had been badly frozen on the last Thule expedition to Arctic America. Despite this handicap Freuchen was still anxious to carry out the original plan, but this risk I could not take. Another well known Danish explorer, Helge Bang- 


\section{NORTH POLE OF THE WINDS}

sted, who had been in one of Rasmussen's expeditions and had a long experience in Greenland, volunteered for this difficult post and was accepted. He was not, however, to go in with the expedition, but to join it near the close of the summer season shortly before the main party returned.

Our freight was shipped from New York to Copenhagen May 10th on the Frederik VIII of the Scandinavian-American Line, and with Erlanson, the botanist of the expedition, I travelled by the same vessel. The remaining members left New York on the George Washington May 18th and arrived in Bremen May 27th. Our old friend of the Morrissey cruise, Dr. Knud Rasmussen, we found to be the idol almost of the Danish people, as we had found him to be of the Eskimos in Greenland. He entertained the expedition in a lavish manner and together with the Honorable J. Daugaard-Jensen, Director for Greenland under the Danish Ministry of the Interior, the difficulties which arose were soon ironed out.

The Disko on which we were to sail has the lines of a yacht with luxurious cabins, saloon and smoke room. She is 233 feet in length and is equipped with Diesel engines which, even when the ship was loaded far below the Plimsoll mark, gave it a speed of eleven knots. 


\section{THE SECOND EXPEDITION}

The second expedition consisting of seven members included four who had been on the first expedition in the preceding year, namely: the director, Belknap who was now second-in-command, Church, and Oscanyan. New members were Clarence R. Kallquist of the U. S. Weather Bureau, who replaced Fergusson as aerologist; Fred Herz of Reno, Nevada, expert mechanic and photographer; and Carl O. Erlanson of the botany department of the University of Michigan, a Scandinavian-American fellow and the botanist of the expedition.

The sailing of the Disko was delayed until June 5 th, making time available which we employed in getting all supplies on board and adding material purchased from Denmark. Besides our own expedition the Disko had on board two small Danish scientific expeditions; one of them sent out to find a suitable place for laying out a base line and beginning a triangulation, for the Danish Government has decided to prepare a modern map of their one great colony. The other expedition was to make a careful determination of the longitude at Kôrnok near Godthaab, the southern capital, and compare this with an earlier determination so as to test the modern Wegener theory of continental drift. 
I have mentioned that the Disko was so heavily loaded that she settled in the water far beyond the Plimsoll mark. More serious, however, her deck cargo of lumber rose to the height of the bulwarks, and on this three heavy lighters were lashed which brought the center of gravity abnormally high and produced a heavy list, first on one side and then on the other, depending on the wind and sea. As most of the cabins had the bunks directed athwart the ship, this caused much discomfort. One went to sleep with his head at the higher end of the bunk, but during the night the list would change and he would awaken with head downward.

On June 14th in a fog as thick as pea-soup the Disko lay off the great fjord on which Godthaab is located, and here we steamed off and on waiting for the fog to lift. A little past noon we were able to see above the fog the sharp horns enveloped in snow of the Hjortetakken, "The Antlers", which rise to an altitude of 3835 feet and provide a striking landmark behind the southern capital of Greenland. Later in the afternoon the fog lifted and we sailed up to Godthaab. The four days during which the Disko lay in the harbor discharging cargo we spent exploring the network of fjords about the settlement, especially the Ameralikfjord and the Kugsukf jord. On the 31st we arrived at Holstensborg. 


\section{THE SECOND EXPEDITION}

When we had embarked at Holstensborg on the Morrissey in September of the preceding year, we had left supplies in a storehouse and had arranged to have others sent in to Camp Cooley by dog-sled during the winter, for at that time we expected to establish our new base on Mount Roy D. Chapin close by. When the attempt was made to transport these supplies it had been found impracticable to reach Camp Cooley because of the deep snow, and so they had been taken to the head of the great Söndre Strömfjord farther to the south. While en route to Holstensborg I had seriously considered penetrating into the interior by this great fjord, and so was very agreeably surprised to learn that the supplies, which were chiefly of pemmican and other non-perishable foods, had already been cached there. It was very quickly decided to charter the Walrus and proceed down the coast and up the great fjord to its head.

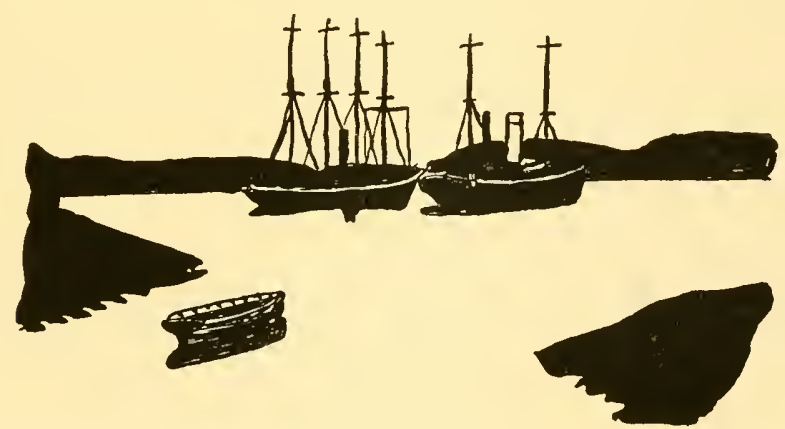




\title{
CHAPTER XI
}

\author{
STORM-BOUND ON THE WALRUS
}

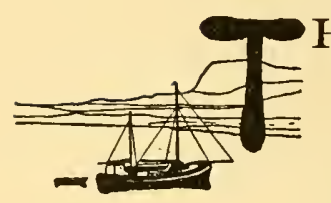

HE Walrus is a motor-schooner of about twenty-six tons which burns "distillate" for fuel in a somewhat unmodern but quite reliable type of motor. The schooner was brought alongside the Disko and our stores transferred directly. The hold they filled completely so that the drums of gasoline and the lumber had to be lashed on deck. The crew consisted of the Eskimo skipper Andreasson and four Eskimo sailors. In the little cabin were two bunks only, but as we always anchored at night, Church slept on the floor of the wheel-house, Belknap and Erlanson on the floor of the cabin, while Herz and myself placed our sleeping bags on the walls of the old storehouse piled on deck and covered by a tarpaulin rigged up as a tent. All the Eskimos, the four 


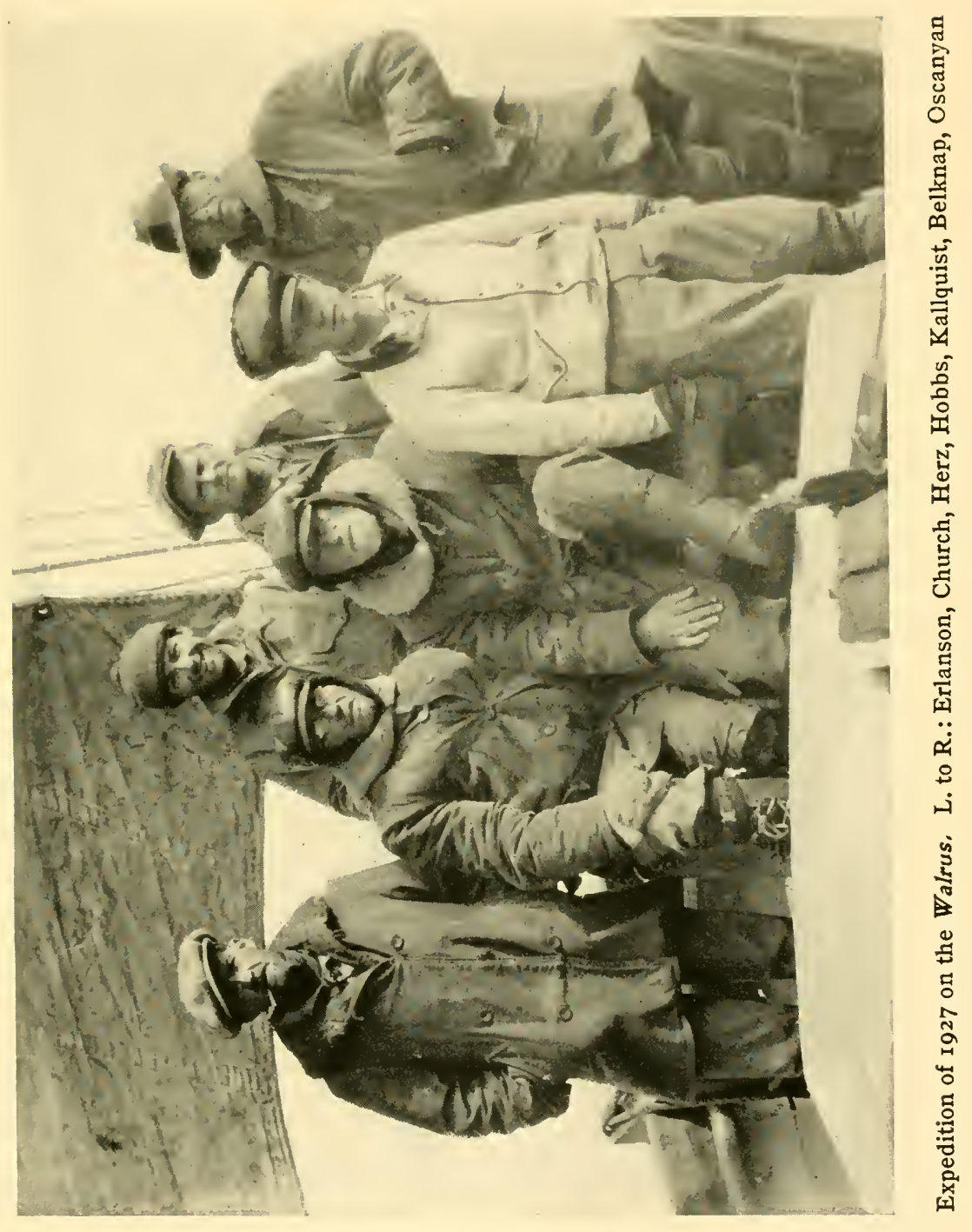



we were taking with us and the crew, crowded into the forecastle, where they slept curled up together.

At noon of the 22nd the Disko sailed for the north, and after taking on our stores from the storehouse and being entertained at dinner by the Governor, we weighed anchor and got away at eight o'clock in the evening. I gave orders to go first to our camp of the preceding year on the Maligiakfjord where we were to get gasoline and other stores, take down the storehouse in sections and transfer it to the deck of the Walrus. At one o'clock in the morning we arrived at Sarfanguak, where those who were awake had coffee with our good friends, David and Mrs. Olsen, but soon after we were off again and tried to get some sleep, as we were to reach our old camp at about seven in the morning. Church, indefatigable as always, remained up all night so as to take water temperatures in the fjord.

When we arrived at the camp Kallquist and I were the only ones awake, and without disturbing the others we went ashore in the dinghy and set to work. Everything was found in good condition. While Kallquist checked supplies and carried them down to the shore, I began sawing off the storehouse roof just under the cornice. After 
a little Herz and Belknap joined us, and the latter I set to work getting breakfast, to which we were able to add some fresh cod caught by our Eskimo Nathaniel off Radio Point. The heavy gasoline drums, each holding about 50 gallons of gasoline, were one at a time rolled down to the shore and in the motor dory taken out to the Walrus. They were followed by the roof and the sides of the storehouse, which were laid flat on the deck and, unfortunately, made access to the hold where our food was stored a rather difficult proceeding.

By three in the afternoon everything was on board and we departed for Sarkardlit to pick up Enok, another of our Eskimos, after which we returned to Sarfanguak. There we were joined by Abraham and Peter, two more of our Eskimos, so that our personnel was now complete. Caribou fawn skins for our fur suits we had purchased in New York and sent in to Mrs. Olsen to make into coats. These were now ready, and with mittens, sealskin trousers and kamiks they were taken on board for those of the party who were to remain throughout the winter-Church, Kallquist, and Oscanyan. Nathaniel and Peter took with them their kayaks and we took on a supply of Danish black bread for our Eskimo companions.

From Sarfanguak our course was down the Iker- 
tôk to a strait at Ikerasârssuk, where we steered south past Sarkak and out to sea into an archipelago of small islands, reefs, and skerries. We planned to stop at the little Eskimo settlement of Itivdlek and there lay up for the night so as to secure the loan of a small lighter to take with us for landing our heavy stores at our base. At this little harbor we arrived shortly before midnight with the midnight sun still above the horizon; for this was June 23rd close to the summer solstice, and Itivdlek is almost exactly upon the Arctic Circle.

Toward morning I was awakened to find the Walrus dragging her anchor and hard up against the rocks of a lee shore within the small bay where we had stopped. Our crew was already awake and had taken a line ashore to windward and were hauling upon it while the motor was being warmed up. With one of these sloops some time is always necessary for heating the motor by flame within a jacket before it will operate. Fortunately we were soon off the lee shore with the motor going. It was, however, about four in the afternoon of the 24th before we had secured our lighter and were ready to weigh anchor. The lighter, the dory and the dinghy were all in tow and now made the Walrus exceedingly difficult to navigate. We soon 


\section{NORTH POLE OF THE WINDS}

passed out to sea and ran into a strong southeast wind and a heavy sea so that we were obliged to run for shelter behind the little island of Inugsugtussok, which has been used by the halibut sloops for a haven and is known as Olsen's Harbor. We had hardly come to anchor before four of these sloops one after the other trailed into the harbor seeking refuge and anchored near us. Even here behind the island there was only partial shelter. One of the halibut sloops had anchored to windward of us, but in the sea running dragged her anchor and fouled our anchor chain. With both boats tugging at our anchor it looked for a time as though both would be dragged out to sea. Fortunately our anchor held while the crew of the sloop worked manfully at their windlass to take up the slack chain and so bring their anchor near to the surface. After several futile efforts they succeeded and their skipper standing in a tossing dory got a rope's loop under the flukes so that they were raised and we were again free.

For three long days we had been storm-bound and there seemed little prospect of any abatement of the storm outside. Our Eskimos of the crew had brought rations sufficient only for the voyage in good weather. Our own supplies were mainly covered deep in the hold, which was almost inac- 
cessible because of the deck cargo. Meester Jensen in charge of the halibut fleet was on one of the sloops, and after advising with him I decided to risk an attempt to proceed down the coast. This was on the 26th when the wind appeared to fall away slightly. Our own skipper Andreasson and our veteran hunter Abraham both argued against the attempt, saying vigorously "Ne apok", which means "no good", but as Jensen was a veteran sailor with eighteen years experience on this coast I decided we would follow his advice and go out.

Our anchor was raised at ten in the evening and as we emerged from the little harbor the sea seemed quiet enough. Church was remaining up to take water temperatures and the rest of us turned in, Herz and I under the old riding sail triced up over the sides and roof of the storehouse. Shortly after midnight I was awakened by the whistling and roaring of the wind aloft and by the billowing and flapping of our shelter which threatened to blow away. This alone indicated that we had turned about and that the wind was in consequence blowing in through the opening of our shelter which was toward the stern. As I hurried to pull on my boots, I aroused Herz and Kallquist. Church appeared almost at once to say that we had buffeted the billows without making 
any progress whatever and having now turned about were running for port. It was now with the greatest difficulty that we were able to manage the three boats which were being towed astern. The dory particularly was wallowing badly in the heavy seas far out astern and disappeared from sight behind each larger billow. I was pleased to observe, however, that the Walrus despite her heavy cargo and her deck load of lumber and the thirteen drums of gasoline was riding like a duck.

Our chief anxiety was for the dory without which we should be seriously handicapped. Hardly twenty-five minutes after turning about the towing line of the lighter parted and with the dory it drifted off. Very skillfully Andreasson turned the Walrus about, though with much wallowing in the seas, and after a little work with boat hooks and lines the fugitive boats were captured. The mate getting into the dory now fastened new lines of hawser. We now turned toward the harbor and though the dory continued to wallow badly and was soon awash, we were nearing the shelter of Olsen's Harbor and succeeded in bringing all in safely.

After bailing out the dory and making all snug, as it was then three o'clock in the morning and we were all chilled to the marrow, we crept into our 
sleeping bags and did not creep out until noon of the next day.

The weather continued bad with much wind and rain and I felt that much valuable time of our short summer season was being lost. None the less I had now learned my lesson that it is futile to proceed until the storm is over. On the night of the fifth day of our enforced delay here, the storm increased and the wind roared through the rigging of the Walrus. There was no let up on the following day. We lay in our sleeping bags getting up to cook our meals over the primus lamp on the shelf in the wheel house. When the meal was ready we would wedge ourselves tightly into the little cabin around its very small folding table.

On the twenty-eighth the sky looked a little more promising, though the wind had not abated, keeping in the southwest quarter, and if for a little it seemed to fall away, it was sure to be in full force within the next half hour.

On July 1st, the eighth day that we had been storm-bound, I was up at eight o'clock in the morning to find the wind much moderated though it remained in the same quarter. Against the mountain background the low-lying stratus clouds seemed to lay motionless. Andreasson, the skipper, remarked cheerily "I yung a luk", which means 
"good", and pointed to the sky. After a brief conference with the Fiskemeester Jensen it was up anchor and we were off. There was still a heavy swell outside, but we were able to crawl at a snail's pace against the seas; but crawl we did and after thirteen and one-half hours spent on a normal five hours run we were able at ten in the evening to make the little harbor on the north side of the Simiutak ("stopper") at the mouth of the great fjord, where we anchored for the night.

On the morning of July 2 we were up betimes and already under way by half past three, though we had not finished our supper the night before until after eleven o'clock. The wind had now died away, but stratus clouds still hung low. We were soon entering the great Söndre Strömfjord by the broad southern entrance. As we moved farther up the fjord the clouds opened up and we could observe the grandeur of the scenery. The fjord was here about a mile and three-quarters wide and from both banks the land rose in precipitous rocky walls to heights of three thousand feet and more. On the southern wall through each cross valley we could see the great arm of the inland-ice which here pushes out to the sea and a tongue of glacier coming down to the very fjord itself. On either side of these couloirs the rock stood up in great 
monuments, at first with horns at their summits, but a little later showing truncated surfaces like the tops of pedestals. Finer fjord scenery it would be hard to imagine.

At about half past ten we passed suddenly from the grand scenery of the coastland zone with its sharply angular features into a country of gently moulded contours, and we at once realized that on a new section we had passed into the great hinterland of two glaciations, just as before in the summer of 1926 when we had entered the gateway of Taserssuak.

The wind now blowing up the fjord from the sea we hoisted sail and made good headway as the tide was also running with us. In choosing this fjord for the base of our Greenland weather station it has been necessary to assume a considerable risk, for no maps exist which tell us anything of the country once the fjord has been left behind. Are we again to be disappointed in our search for a suitable site? We have our entire outfit on the overloaded Walrus and the fjord up which we are now sailing has seemed to offer the only remaining opportunity within this part of Greenland of reaching by vessel the area close to the ice-cap. As we get closer and closer to the head of the fjord it begins to look as though we were to meet 
disappointment again, and the increasing muddiness of the waters shows only too clearly that we are now close to the head of navigation. The sails are furled and on half speed we proceed taking soundings every few minutes. But now our binoculars bring out a small cataract tumbling over a rock cliff off the port bow and near it what from the distance appears to be a possible landing. We come to anchor and go ashore in the motordory. The landing is a good one and the stream is one of excellent water fed by a lake. Above the landing there is a fifteen foot bank of glacial clay and above this a sort of shelf level enough for a camp site. We are overjoyed, for the maps show us that this locality is distant only about twentyfive miles from the edge of the inland-ice.

One thing is yet to be learned. Is there in the neighborhood a suitable elevation on which to erect our station, and is the grade by which it is reached possible for our transportation? Scouting parties are sent out in all directions and after a couple of hours we re-assemble, for reports. Several possible sites have been discovered, but Kallquist has found a rounded summit about three miles distant, with a small lake less than one hundred yards from the summit. The horizon about this summit is low, and with the water supply available the only 


\section{STORM-BOUND ON THE WALRUS}

question remaining is whether we can reach the summit from the landing by easy grades. This seems possible and we decide to establish our base here. 'The day, which is my birthday, has ended gloriously. We go at once on board, have our supper and begin the unloading of the Walrus, for as soon as possible she must start back to Holstensborg. The halibut sloops which were with us at Olsen Harbor will already have reported us safe after the storm, but the crew are on short rations and the vessel is needed at Holstensborg.

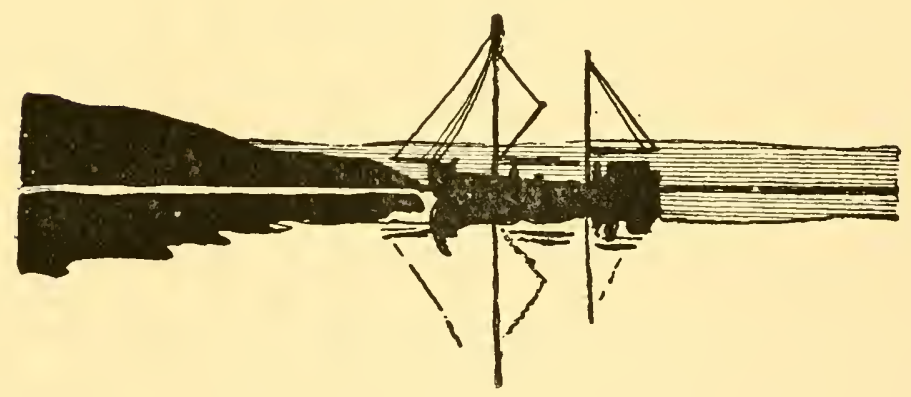




\section{CHAPTER XII}

BUILDING THE EXPEDITION BASE ON MOUNT EVANS

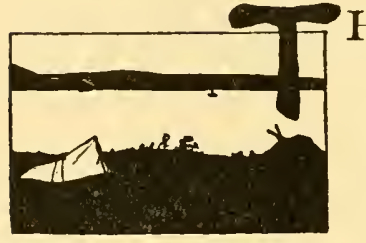

HE camp which we set up at the head of the Söndre Strömfjord we named Camp Lloyd in honor of the late Dean of the Graduate School of the University, news of whose sudden death had reached me just as I was sailing from Boston. The height of the elevation on which we were to erect our aerological station and weather observatory, we determined as $\mathbf{1 2 9 4}$ feet, and this we named Mount Evans in honor of Edward S. Evans of Detroit, a good friend of the Expedition and especially active in promoting aviation. From the summit of Mount Evans we could get a clear sweep of the horizon in all directions and to the eastward could look off on the white expanse of the inlandice. 
Very early on the third, the day after our arrival, we took up the heavy task of unloading the vessel, making use of the lighter, the dory, and the dinghy, all in tow by the motor of the dory at the head of the string. Our strenuous work did not halt until eleven o'clock at night, when very tired all repaired to the tents which had been set up on shore. There still remained on board the $W$ alrus besides the lumber about three loads for all our boats. Skipper Andreasson was, however, very anxious to get away, and at four in the morning I was called by Church to say that he had observed the crew rowing ashore with another load. I was loath to call Belknap, who operated the motor, as he had had a particularly hard day, but there was no recourse. Without complaint he got up and soon everyone was again hard at work. The lumber was made into a raft and towed by the dory, but it had to be brought in at low tide where the range of tide is near fifteen feet, and so Belknap and Church found themselves stranded far out on the mud flat. They were later brought off by Herz using the canoe for the purpose and leaving the dory and the raft securely anchored to be brought in on the flood tide. The landing of the lumber completed the work of disembarkation, and the Walrus now departed for Holstensborg. 
As a rain now threatened we made haste to get our several piles of material under cover, using tarpaulins and also the sides and roof of the storehouse which we had brought from the camp on the Maligiakfjord. The old riding sail which had been given us by Captain Bartlett, and which had served as shelter at the camp of 1926 , we now cut up for a wall tent twelve feet by twelve. Our Eskimos, Abraham and Nathaniel, were set to work to sew the pieces together and the tent when ready was set up on a flat ridge of rock to serve as a store and dining tent. Supplies were piled inside against the back and walls to stiffen the structure, and in front of them the provision boxes in regular use were opened up and placed on their sides so as to serve as shelves. In front of these were placed the chests or lockers with lids, and these served as seats about the folding table in the center.

At the back of this tent to serve as cupboards we had brought several of the chests designed by Major Fiala on his Arctic Expeditions. These were stout packing boxes eighteen inches by twenty-four and provided with rope handles at the ends. They had hinged lids and within the cases on either side double cleats for shelving. We improved them slightly by adding stout cleats on one end outside so that they stood firmly on end 
in spite of the thick rope handles. The canvass of the riding sail was old and leaky and so we constructed a fly from new heavily water-proofed thick duck such as we are to use for the roof of the observatory. Our dining and store tent and our general assembly room and office as well was thus made thoroughly waterproof. It was not so easy to protect it during high winds.

Our sleeping tents we grouped around the wall tent and the storehouse brought from our camp of 1926 was later set up somewhat higher on the slope and was used temporarily as an experimental radio station by Mr. Oscanyan, I regret to say without any success whatever in reaching the United States.

In most respects Camp Lloyd proved a very satisfactory base for the Expedition. Situated less than one hundred yards from the fjord landing and some sixty-five feet higher up, its never failing source of good water was less than one hundred feet away. We could gaze out across the fjord, here widened to about six miles, though elsewhere averaging from less than two to less than three miles. A prominent bluff which we named Point Emmons partly enclosed a bay in front of Camp Lloyd which we named Michigan Bay. Between the forks of the fjord about two miles away 
rose a high plateau already called in the Eskimo language Nakajanga, a word which means "the reindeer or caribou country". Though we never saw caribou on it, we rarely visited it, and the wild unexplored area across the fjord and lying between

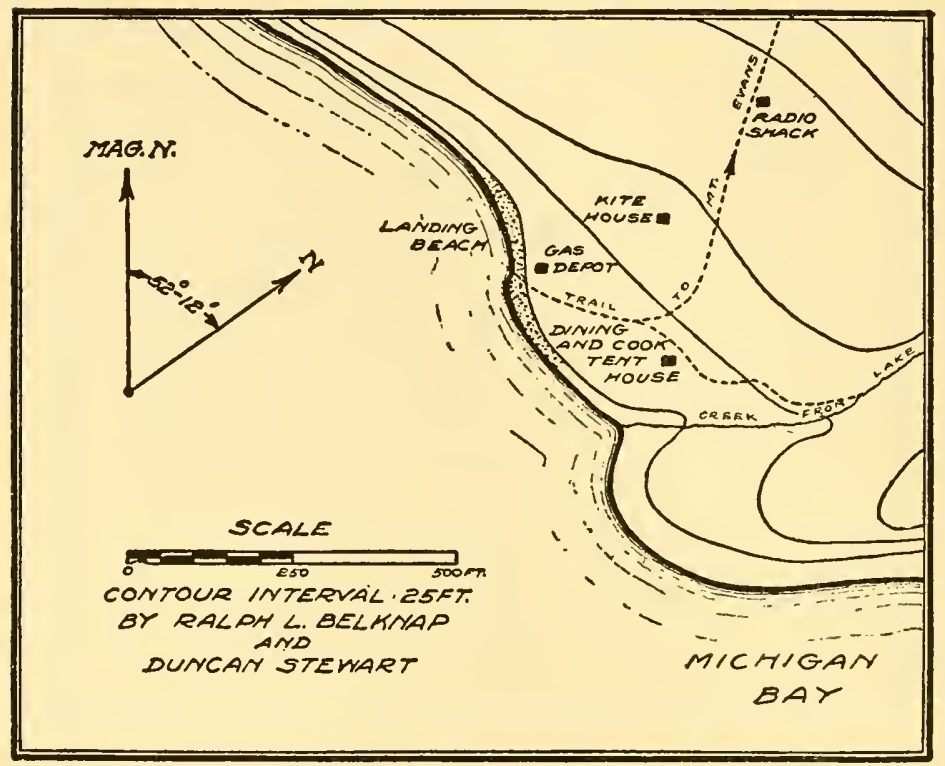

it and the Knud Rasmussen ice-arm northwest of Sukkertoppen is today the best preserve of these animals still remaining in West Greenland. When the sun sinks in the west and the sky is decked out in gorgeous colors, the view down the fjord from Camp Lloyd may be compared favorably with some of the finest landscapes anywhere to be seen (see map inside of cover). 
As soon as Camp Lloyd had been organized the heavy task of erecting the weather observatory on Mount Evans was undertaken. This structure had been designed by Herz on the basis of experience gained with Professor Church at the Mount Rose Weather Observatory in Nevada, and he was, therefore, placed in charge of the construction. Kallquist was associated with him as principal assistant, and the two men established themselves at once in a tent on the summit of Mount Evans. The remaining members of the Expedition and the four Eskimos now began packing on backs and shoulders the materials of construction-the joists, boards, canvas, balsam wool, the window and door frames, and the windows and doors themselves.

A trail was laid out which would have the easiest grades even though it involved some detours, and this trail was clearly marked out by rock monuments. It represented a total distance of about three miles with a vertical rise of nearly 1300 feet. This trail was soon worn into a path easily followed except where the rock ledges outcropped, but the set of monuments was intended to serve also for the winter when the ground was snow-covered. Day after day in monotonous succession a caravan of from four to seven men would start out from Camp Lloyd in the morning, each with two pieces 
of scantling two inches by four inches in cross section and twelve feet long, the pieces lightly nailed together for convenient handling. Somewhat later these were replaced by four boards eight inches wide and twelve feet long, varied at times in

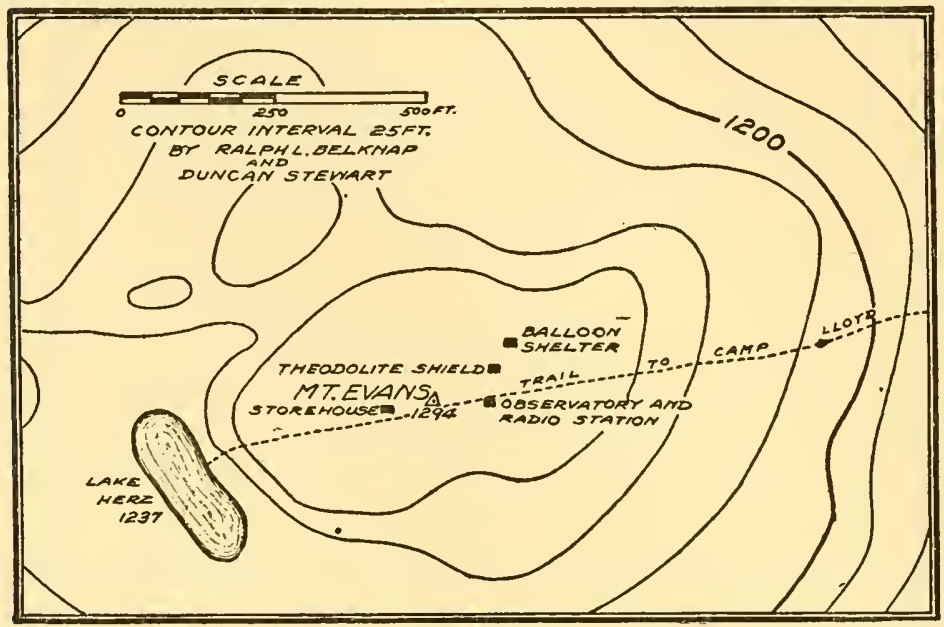

favor of a roll of heavy water-proofed canvas for the outside cover of roof and walls, or the unwieldy fifty pound rolls of balsam wool for the insulation. It was a tour de force, which we at first found very arduous, but which later, as we became hardened to the work, thought none too difficult; and to carry two such loads each day to the summit of Mount Evans was not exceptional.

Herz and Kallquist, who remained on the summit, erected the frame of the hut, taking on Erlan- 
son for a time as their assistant, though as a rule our botanist was kept free for his botanical studies because the flowering season of the plants would soon be over. Oscanyan also was relieved of this labor and gave his time mainly to his radio preparations. Abraham, who was engaged as hunter, is too old to do heavy packing. Once more our Eskimos have disappointed us as hunters and especially so Abraham, for he is a man of much experience in hunting and one who enjoys a great local reputation. He is certainly a fine shot with the rifle, but he seems to be a hunter who has every qualification except that he is unwilling to hunt-go out after the game. Already in the summer of 1926, when at Camp Cooley he and his Eskimo companions were starving, a fat hare hopped into our midst and got up upon his haunches without any of our Eskimos observing him. It was necessary for me to draw Abraham's attention, whereupon he went after his rifle, the hare obligingly standing at attention the while. Several seals had appeared off Camp Lloyd, and as I am up early to get the breakfast I see them and must go and waken the Eskimos, by which time the game is generally too far away. Ducks also settle upon the fjord close to our camp in the early morning, but by the time the hunter's arrive they have moved too far away to be bagged. 
For the salmon said to be found in this fjord we have brought gill nets generously loaned us by Fiskemeester Jensen, but Abraham is unable to

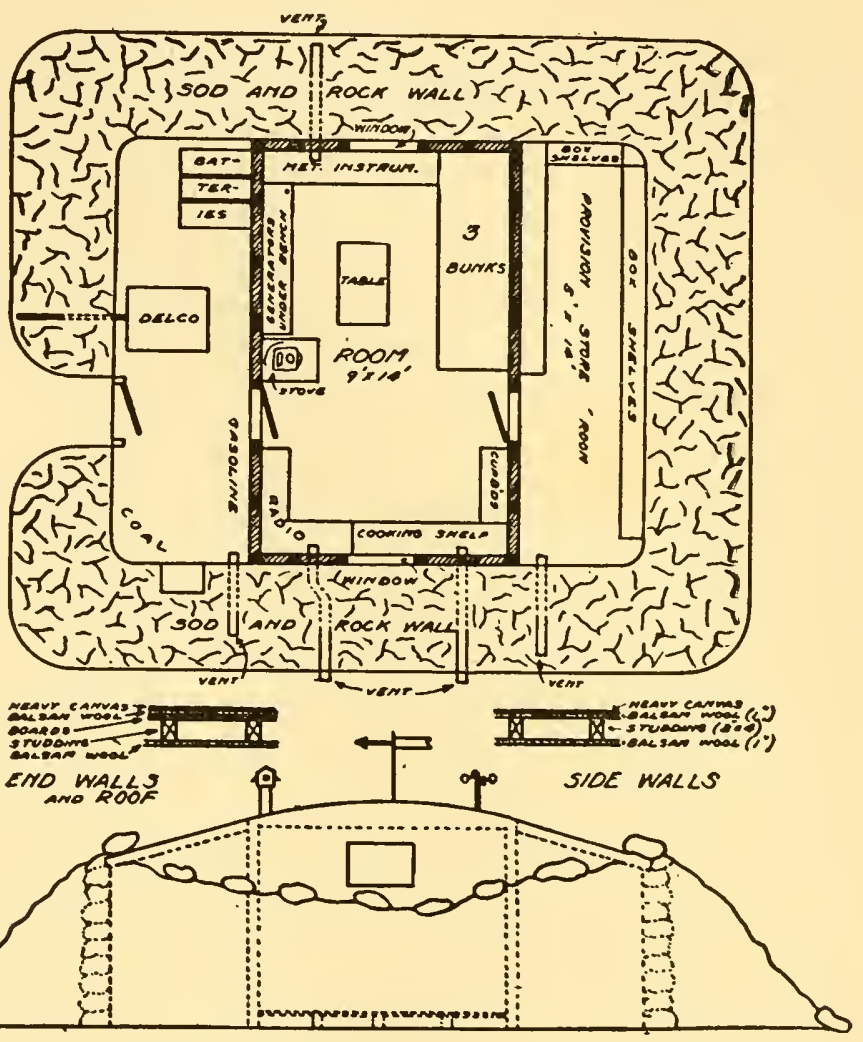

catch any fish with the exception of a few bony sculpins. This is a great disappointment to me, for the food brought in for the Eskimos has been based on Abraham being with us as hunter, and the amount is strictly limited. I have three hundred 
pounds of bison pemmican which was prepared by the Canadian Government, but this the Eskimos refuse to eat. The following winter it was disposed of with great gusto by Bangsted and his Eskimo Marius.

On the tenth Belknap, Erlanson, Abraham and I started out in the motor-dory to make a reconnaissance toward the inland-ice. Arriving at Dory Landing Abraham was put ashore to hunt and Erlanson to botanize, while Belknap and I started off to scout for the depot of provisions which had been laid down by dog sled during the preceding winter. We went along over the rocks which rise above the fjord and crossed wide expanses of sand and mud flat to Karkanguak within about ten miles of the ice border, but without finding the cache. We returned to the dory landing and took on Abraham and Erlanson when we started back to Camp Lloyd in the dory. Abraham took his place in the bow and as we proceeded down the fjord he observed the ripple on the surface of the water which is made by a big seal. We gave chase, turning in and out as the seal changed directions, apparently greatly alarmed by the sound of our motor as it got closer and closer to him. At last he was obliged to come to the surface to breathe when Abraham shot him in the 
back of the neck. Immediately his hind flippers came to the surface as he sank in deep water, the surface surtinged with blood. It was impossible to secure him though Abraham returned to the place in his kayak when the tide ebbed.

It was well understood by all of us that our station on Mount Evans would sooner or later be subjected to winds of hurricane force blowing off the ice-cap from the southeasterly quarter, and the form of the hut had therefore been made such as to resist these winds. On either side of the main central room there were low storehouses sufficiently high for one to stand in them on the inner side, but with roof sloping away to a low wall on the outer side. This wall was built up of boulders and was banked up outside by tundra mat mixed with boulders.

The labor on the hut stretched out over the greater part of the summer season-nearly six weeks in all, though time was found for several reconnaissances up the fjord to the inland-ice or across the fjord to Nakajanga.

Our most serious problem in connection with the hut on the summit was to carry up the Delco generator, which weighed almost 300 pounds, and the three "iron-clad" storage batteries each of which weighed about 240 pounds. The problem 


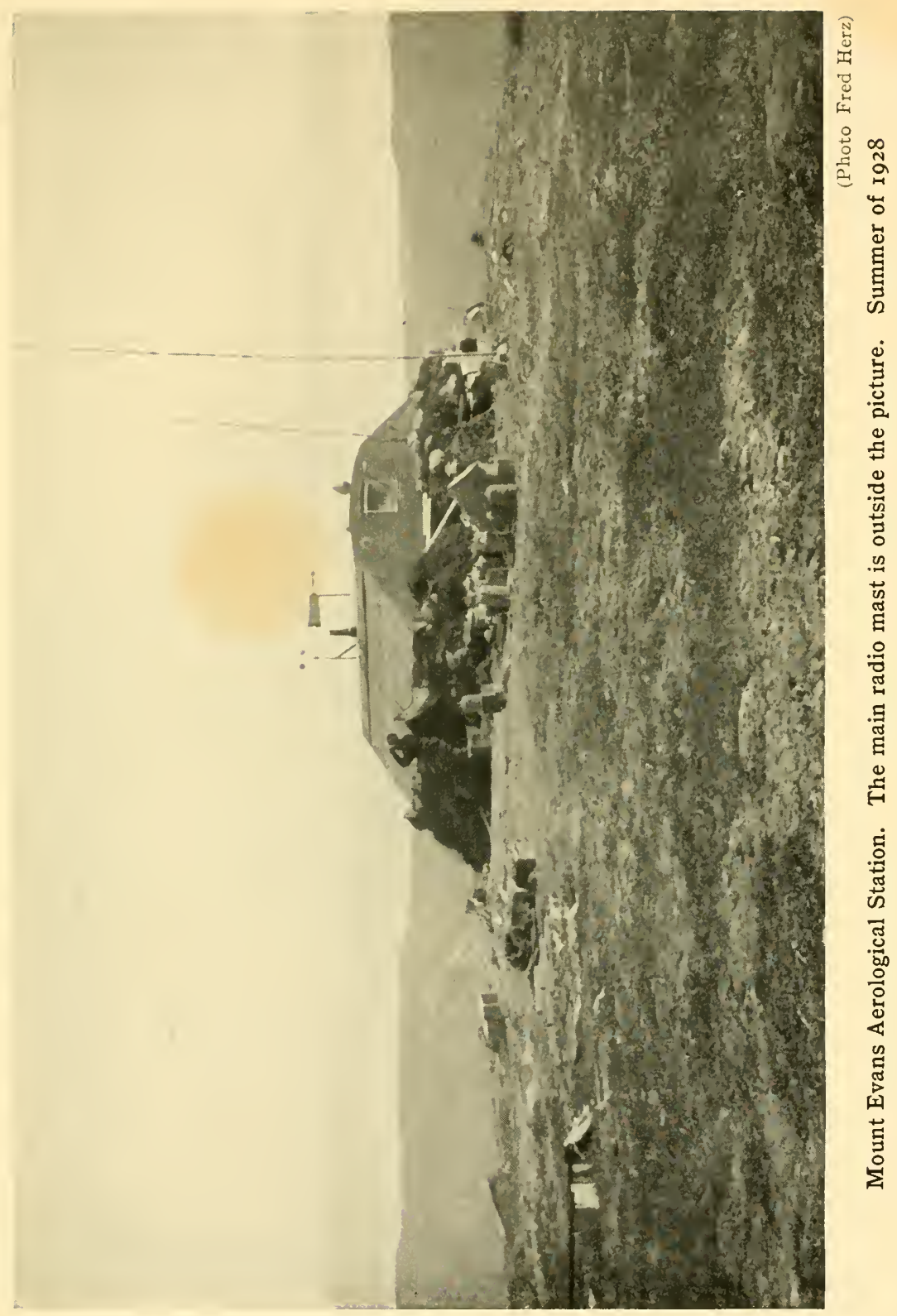



was finally solved by putting one of these heavy bodies on the sledge beneath which in a central position we had attached as a wheel the cast-iron reel of our captive balloon. To balance the vehicle a gee pole was used. With ten men harnessed in as draft animals and with Herz balancing the load and steering with the gee pole, we were able to make the summit in about six hours. Although most of us were already hardened by packing, the work was very strenuous and one trip each day with frequent rests was all that we were able to manage.

Our wireless plant we at first set up in the old storehouse at Camp Lloyd, since the Reinartz topographic requirement was there fulfilled that no land shall rise so near the station as to make the vertical angle greater than eighteen degrees. Though reception at the station was satisfactory enough, Oscanyan did not succeed in sending satisfactorily.

The thought had been often in my mind that a wind of hurricane force might visit us while we were building the hut and before it was sufficiently secure to hold. On the fifteenth with the frame already up a rather high wind which Kallquist estimated to have a force of about 45 miles per hour, nearly carried away the tent which Herz and Kallquist 
occupied on the summit. When we had the central room with its roof and the southeast storeroom with its protecting wall complete, but before the northwest storehouse had been begun, we felt that we should begin our regular observations. Our instruments were therefore carried up and put in place, and on July 21st Kallquist began his daily balloon runs. By this time the men had been able to abandon their tent and had moved into the hut on July 17th. On the following day there was a hard blow which the anemometer registered as $\mathbf{7 8}$ miles per hour, and on the following day there was a foehn sky with dark terraced mushroom shaped clouds.

We now worked hard with the Eskimos to get the windward wall of the hut completed. Every day we are getting up more of the meteorological equipment. The black flies are especially troublesome, but by night of the 18th we have the roof of the weather storeroom with its protecting wall finished and the floor of the central room in part laid. On the 19th a high wind nearly ripped the canvas off the roof when it was only temporarily anchored. Calling all hands we passed a rope over, anchored it to rocks on either side and made taut with a twister. On the 21st the anemometer recorded gust velocities of 120 miles per hour, but 


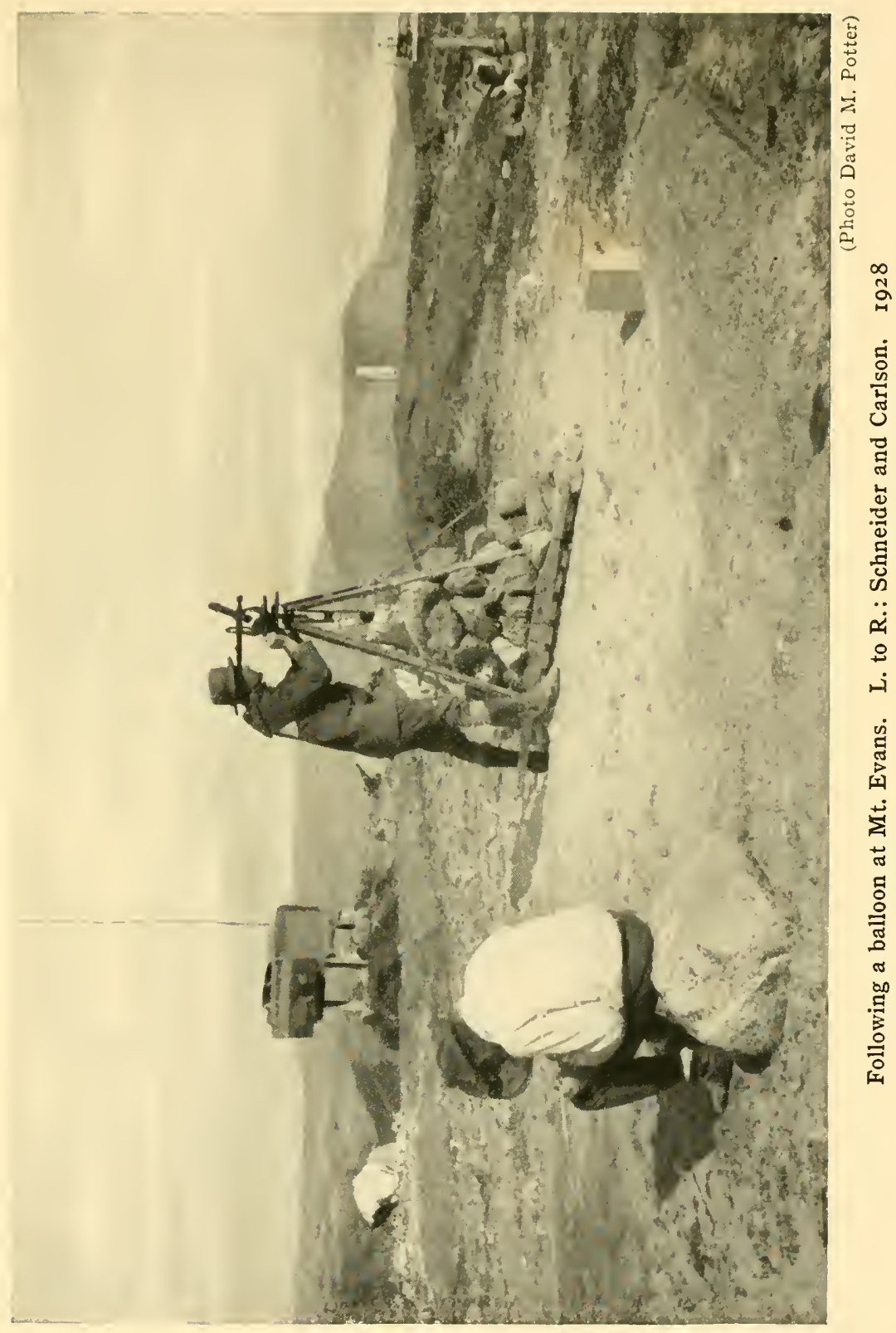



the hut stood firm. Kallquist, who was within the hut, did not realize that there was a high wind until glancing through one of the windows he saw our heavy carrying device waltzing past the hut.

Several times during the winter seasons the hut was subjected to storms having wind velocities in excess of one hundred miles per hour; but each time it stood firm though the wireless mast came down several times.

The insolation with balsam wool proved very satisfactory. The experience of all polar expeditions having shown the importance of adequate ventilation of winter quarters, vent pipes were inserted in the walls of the living room near the floor and ceiling at both ends of the room.

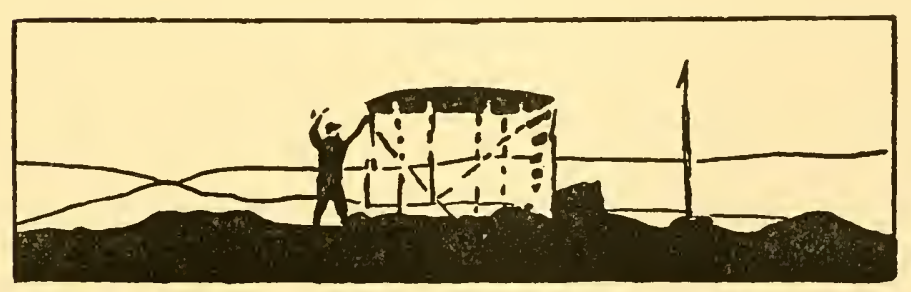




\title{
CHAPTER XIII
}

\author{
RECONNAISSANCE
}

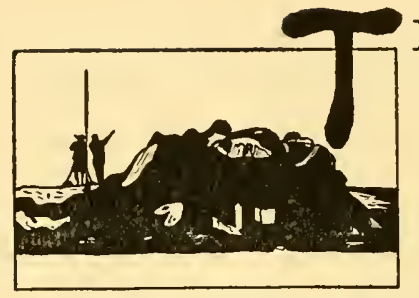

HE twentieth of July as we were completing the more urgently needed part of our construction on Mount Evans, Abraham had come to me to say that he wanted to go after caribou with Nathaniel and Peter, and this request I was glad to grant. Erlanson was to go on a botanizing trip to the Nakajanga region across the fjord for a period of several days. Belknap and I were to start on a reconnaissance trip to the inland-ice in preparation for our major expedition of the summer. We decided, therefore, to start out at once and take Erlanson with us in the motor-dory towing a canoe which was to be left with him.

Church and Kallquist were the ones left in Camp. The weather was fine and the fjord smooth. After depositing Erlanson under the Nakajanga, 


\section{RECONNAISSANCE}

Belknap and I made the attempt to reach the head of the fjord in the dory, but after running aground several times we gave up the attempt. Several times a seal bobbed his head up in front of us, but we had taken no firearms with us. Going ashore at the Dory Landing we left the dory there and went on afoot in the direction of the inlandice. We took with us four days rations, our sleeping bags and two one-man tents. As we started out a fierce foehn wind was blowing down the valley off the ice-cap and that night we camped among sand hillocks back from the river so as to get what protection we could from the storm. During the night the wind reversed direction and blew with great force up the valley driving the sand against us. Our camp was a dry one, though on our earlier trip we had found sufficient water in hollows of the nearby rock surface. The following night we camped on a small lake which is frequented by geese. Mosquitoes and black flies were both especially troublesome.

The next day we took our course past Karkanguak and made search for the provision depot laid down for us the preceding winter, but without success. On the morning of the 22nd we were up at half past five o'clock and after a breakfast of erbswurst and pemmican cooked in a tin can and 
eaten with improvised chop-sticks, we started out again. We crossed fresh caribou tracks and came to the edge of the inland-ice near where there were two glacier tongues which received the names of Russell and Leverett Glaciers. Without success we attempted to scale the precipitous front of the Russell Glacier which was characterized by loose blocks and falling fragments. We then forded the wide gravel flat with its braided streams in front of the Russell Glacier, going over our high boots in doing so. We then ascended a steep slope off the south wall of the glacier, and coming to a small lake close to the edge of the ice we now found a place where we could get up upon the ice.

Over this glacier we advanced a mile reaching an altitude of nearly 1300 feet. The ice is here covered with stony debris, is deeply crevassed, and we saw one large "mill" where the surface stream descended into the glacier. We now turned back and coming down off the ice descended the slope, again forded the sand flat, and crossing heavy sand dunes reached the little lake where was our camp on the inward journey and which we had called Goose Lake. This time we followed down the Watson River where it passes the Karkanguak, again made diligent search for the lost depot, but again without success. Here the river rushes 


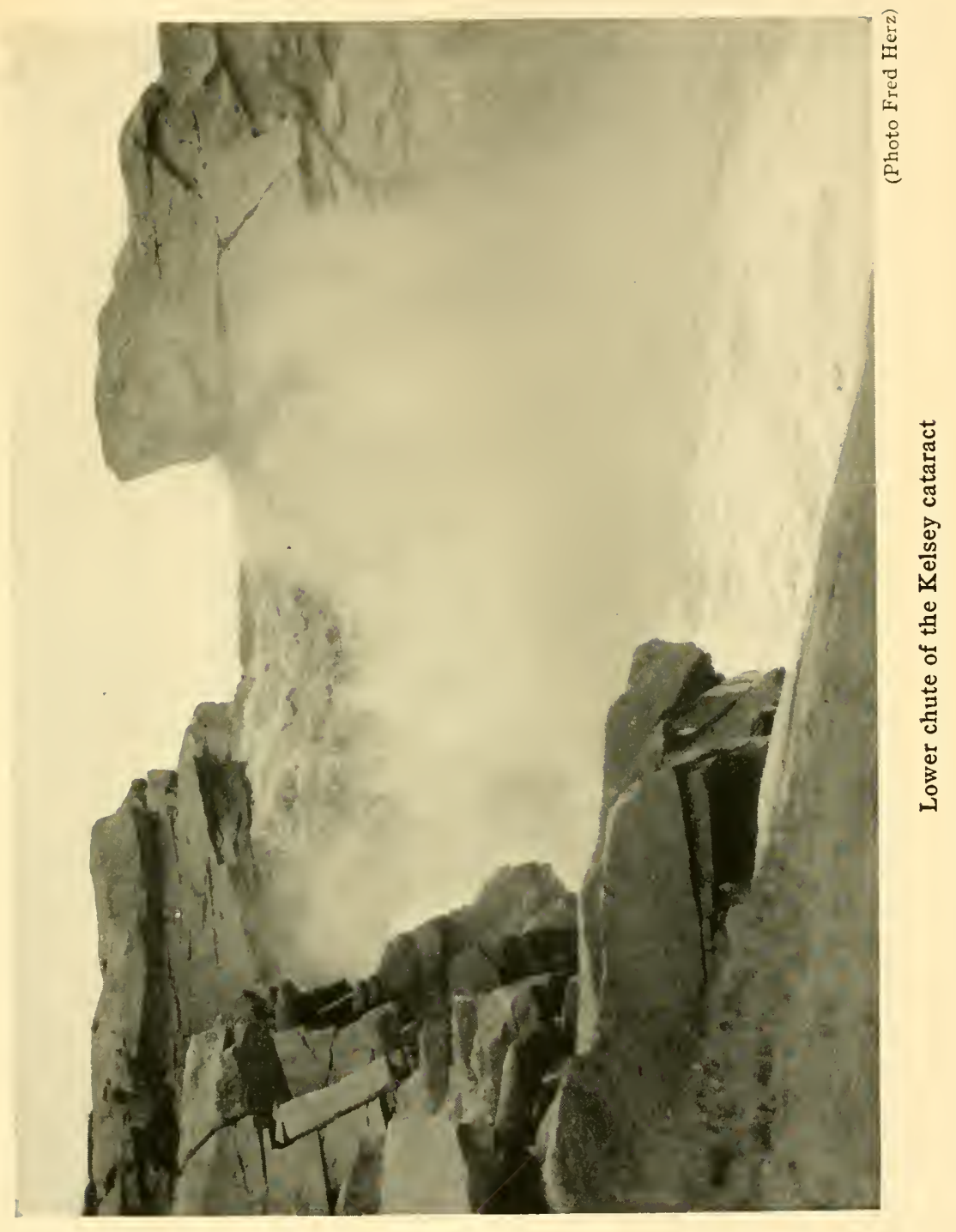



through a rock canyon with rapids above and below. The lower ones, which because of others still farther down the river, we have called the Middle Rapids, are within a particularly wild gorge rather difficult to get past when loaded with heavy packs. The next night we camped beside the Middle Rapids after emerging from the gorge. Here we found fine water in a spring and also in a cold pool among the rocks.

The next day, the 23rd we made our way down to the Dory Landing, only to find that the dory had been seriously damaged during our absence by chafing against a rock near the high tide level, doubtless during the storm of the 21st. After launching the dory it was necessary to bale continuously to keep the water down until we could reach Camp Lloyd.

Much has happened during our absence. The wind velocity during the southeast storm of the 21st was measured at our observatory as 120 miles per hour for a period of two minutes on the new three-cup single-register anemometer loaned us by the U. S. Weather Bureau. At Camp Lloyd with a hand anemometer Church had obtained much the same value. The storm arrived coming off the ice-cap from the southeast on Thursday afternoon, the 21st, and continued through Friday 


\section{NORTH POLE OF THE WINDS}

morning, swinging around into the southwesterly quarter. One of our canoes which had been left high and dry upon the land was overturned by the wind and badly chafed as it moved along over the tundra surface. The cook shack behind our dining tent was wrecked.

Abraham and his party are back with a bag of geese, but with no caribou. Erlanson finished his work at the Nakajanga in two days and then started back in the canoe at a time when the fjord appeared to be quiet. When he was part way across - the fjord is here two miles in width-he was caught in a gust of wind which raised heavy seas and willy nilly he was carried six miles down the fjord. By strenuous efforts he just managed to make a landing on a rocky point as he was being carried still farther down the fjord.

Two Eskimos in their kayaks had come in to Camp Lloyd from the coast during our absence, making the trip from Holstensborg and Sarfanguak over the winter dog sled route by way of Sarkardlit, a route which includes a portage eleven miles in length. They were caught in the big storm of Thursday and Friday and were apparently somewhat shaken by the experience. They had left for the coast on Friday intending to travel all night. 


\section{RECONNAISSANCE}

Our trip to the Russell Glacier has permitted us to make out an adequate ration for the ice-cap trip now soon to be undertaken. We have eaten per man per day two thirds of a pound of Beauvais pemmican, one third of a pound of pilot bread, one ninth of a pound of Knorr's pea soup, one fourth of a pound of raisins, one bar of chocolate and tea. This is all concentrated food, but I think for a long trip a pound of Armour pemmican, a quarter of a pound of pea soup and one half a pound of pilot bread would be a better ration. In meals when it is served the pea soup takes the place of tea.

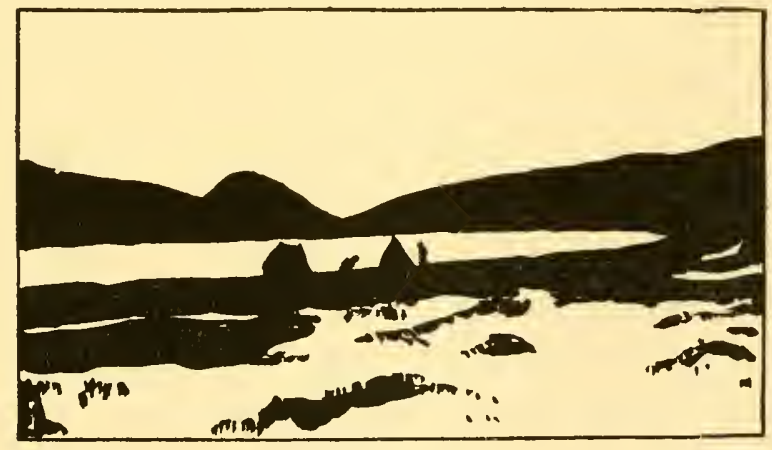




\section{CHAPTER XIV}

THE SECOND EXPEDITION TO THE ICE-CAP

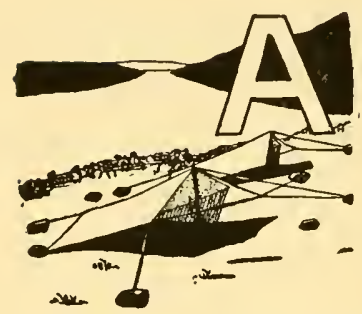

FTER the reconnaissance of the ice-cap margin by Belknap and myself, we began to make preparations for an expedition over the ice surface as far as conditions permitted, there send up balloons and in addition lay out a series of bamboo stakes to be located and after a sufficient interval, relocated by transit from the ends of a base line off the ice margin. This, had it been carried through, would have determined the rate of movement of the ice at different distances within its margin. This problem was peculiarly that for Belknap to undertake, since he was the surveyor of the expedition.

It would be necessary to make several advance trips under packs as far as the ice margin, and we 
decided to set up tents as way stations where provisions and blankets would be deposited and where we would plan to sleep. To rid ourselves of the insects, especially the black flies and sand flies, and also to reduce the amount of bedding required, we did our trekking mainly at night and slept in the day time. When the sun was shining on the tent the interior would get quite hot, but this could be avoided by putting a blanket over the canvas on the sunny side.

With the three younger Eskimos Church and myself packed regularly. Our plan had been to take Kallquist along on the main expedition for extended balloon work, but on the evening of the 28th he met with an accident which upset our plan. While preparing malted milk over the primus lamp he upset it on his foot, the scalding fluid going into the back of his kamik. He was unable to get the kamik off before a blister nearly two inches in diameter had formed on his heel. Oscanyan, who was with him at the time, treated the place with mentholatum and later Herz gave the foot daily treatments. This mishap effectively prevented walking, but in hopes of his rapid recovery we delayed the definite departure of the expedition, meanwhile proceeding with our packing. 
By August 1st the last of the heavy equipment of the weather station was on the summit of Mount Evans, though the coal for the winter was left to be managed largely by the winter party using a small hand-sled after the snow should be on the ground. An air-tight coal-stove with a five inch grate and of a type now obsolete was installed to heat the observatory.

For use on the ice-cap we have brought with us a four-man tent of special construction made according to my designs by Major Fiala, outfitter of polar expeditions in New York City. Though this tent had a water-proof floor we took along four large reindeer skins for insulation. These skins had not been properly cured and Abraham, who fully understands the process, drafted his Eskimo companions, and after first wetting the skins scraped off the flesh and a portion of the hide with sharp-edged stones. This reduced the skins to a soft flexible condition, but they absorbed moisture and they required to be dried out in the sun each day.

That part of our equipment which was to be used in laying out the base line and in locating bamboo stakes, we cached outside the ice margin. This included an invar tape and a ten-second transit, both instruments kindly loaned us by the United 
States Coast and Geodetic Survey. Our traveling equipment for the ice-cap consisted of an Alaskan sled with hodometer, a four-man tent with two poles, our Woods Arctic sleeping robes with four reindeer skins for carpet, four ice axes, bamboo poles, $\mathbf{1 0 0}$ feet of climbing rope, climbing irons, ice chisel and hammer, primus lamp with ten gallons of kerosene fuel, cooking pail, cups and spoons.

The scientific equipment for the ice-cap included a thirty-second transit, hydrogen generator with calcium hydride, folding canvas water bucket, and a supply of balloons, small pyrhelometer, altimeter, aneroid, compass, hand anemometer, psychrometer, ice thermometers, cameras and moving picture apparatus with a supply of films. We took along also a few necessary medicines, but especially holocane for treatment of the eyes in the event of snow-blindness, and all in the party were supplied with snow spectacles.

Our provisions consisted of one hundred pounds of Armour's Pemmican, twenty-five pounds of Pilot Bread, one hundred cakes of Peter's Gala chocolate, a supply of Knorr's erbswurst, tea, sugar and powdered milk (klim). These provisions were for the entire expedition and not for the ice-cap portion alone. 
We had hoped that time would permit of an attempt to sound the ice to determine its depth by echo methods, and for this purpose we had brought with us an expensive and heavy geophone kindly loaned the expedition by Dr. DeGollyer of New York City. The dynamite, fuses and fulminating caps necessary for the sounding experiment we had obtained in Sweden and had brought aboard the Disko off Helsingor. These explosives had been brought to Camp Lloyd and stored under an overhanging rock away from the camp itself. It was a great disappointment not to be able to carry out these studies, but so much time had been devoted to building the observatory that in the limited time remaining and with the great difficulties in the way of transporting our equipment to the ice front, it was clear that this part of our program would have to be abandoned for the present at least. It was even doubtful if time would suffice for laying out our base line and locating bamboo signals from it. As a matter of fact this part of the program was only partially completed.

The first stage in the transportation of our equipment consisted in taking it as far as the Dory Landing about three miles up the fjord from Camp Lloyd. The landing could be made with the dory only at or near flood tide and was much easier 
at the time of the spring tide. One of these spring tides had caught us napping before we started on the expedition, and the dory carried up on the beach was scraped against a boulder until a considerable area near the keel was worn thin and produced a leak. This leak had been repaired by Herz and Belknap, and Belknap now suggested that we try out the dory by a trip across the fjord to the south arm beyond Nakajanga. He took Erlanson with him to make a botanical reconnaissance, and I suggested that Abraham also go along with his rifle. The party returned in the late afternoon enthusiastic over the performance of the new Lockwood motor. Erlanson had shot a goose and a duck.

On August 4th I decided that Belknap, Church, Erlanson and I should make a start for the inlandice the same afternoon with the four Eskimos packing in, so as to find if possible the lost depot of provisions and to make a temporary base above the Upper Rapids of the Watson River. We left Camp Lloyd at three with Belknap and Erlanson going ahead in the motor-dory towing the canoe and proceeding to Dory Camp with the flood tide. Church and I with the four Eskimos started out on the trail along the shore, all of us carrying heavy packs. The dory got in ahead of us and fortunately, before the tide went out. Erlanson and 
Belknap pioneered some distance ahead with the canoe and Erlanson fired a charge of No. 2 shot into a seal but he got away. We camped for the night near the landing, getting drinking water from a little lake situated about one half a mile northwest of the landing. At four o'clock next morning I roused the camp so as to get an early start, and we had a breakfast of tea, pemmican and pilot bread. By six-fifteen o'clock we were off under heavy packs and found that we made an advance of about a quarter of a mile each five minutes. We adopted the plan of trekking for five minutes and then resting five, which worked out very well.

Just before noon we saw a rookery of freshwater seals and counted thirty-two sunning themselves below the Lower Rapids of the Watson River. We were too far away from them for effective shooting and they were surrounded by a wide area of rapid water and quicksand which made a nearer approach impracticable. After a hard day during which we made nearly ten miles, we camped at four o'clock in the afternoon beside the Middle Rapids, an old camp of Belknap and myself and one supplied with good water in a pool hidden under the rocks. The water in the rapids is of course fresh but is so charged with glacial 
mud as to be hardly palatable. Here we set up a tent as one of our regular relay camps which became known as Camp 2 or the Karkanguak Camp. Just east of this camp site rise two sugarloafshaped elevations, the higher of which lying farther east is widely known by the Eskimos at Karkanguak. On the march today while crossing the broad sand flat we came upon the fresh trail of a caribou cow with her calf.

The morning of August 6 was cloudy after a very slight rainfall during the night. We broke camp at five-forty-five in the morning for a long march and lunched on the sand flat at nine-thirty surrounded by many small dunes built up about willow shrubs. Here also we established a relay camp which became known as Camp 3 or "Sand Lake Camp" (see cut p. 153). We must now be near the lost depot of provisions and we decided to devote the afternoon to searching for it. Our entire party of seven set off in different directions for this purpose, though I planned to climb the high ridge to the northward in order to get an extended view toward Camp Cooley at the edge of the Nordenskjöld Glacier. From the crest of this ridge, which was found to have an altitude of $\mathbf{1 4 6 0}$ feet and which I named Mount James B. Ford, I looked down over a grassy slope upon a lake 
stretched in an east and west direction and about six miles in length which I named Lake Marvin after the Chief of the U.S. Weather Bureau. Continuing now eastward I reached another crest and could see in a direction about north thirty-five degrees east the long line of nunataks or rocky reefs surrounded by ice which lie to the southward of Camp Cooley.

Descending now the slope of this ridge I was hailed by Enok, who brought a note from Belknap with the good news that the long lost depot of provisions had been found. We had begun to fear that this cache would escape our observation and we were much cheered by the discovery. The depot was hidden under a bank of the river near the upper rapids and contained two hundred pounds of Armour's pemmican, twenty-five pounds of sugar and over fifty pounds of other provisions, ten gallons of kerosene, eleven eighteenfoot bamboo poles, matches, etc. Everything except the onions and some desiccated eggs appeared to have stood the winter without injury.

We now made a cache of these supplies at our Sand Lake Camp, protecting them in heavy duffle bags from the depredations of the foxes, and after Belknap and I had caught two hours of sleep we started back to Camp Lloyd in the night to avoid 
the flies and to sleep warmly during the day. Erlanson and Abraham were left at the camp so that the former would carry out his botanical studies.

At the Karkanguak camp Belknap and I turned in at nine o'clock to sleep using one blanket and a bed cover between us, but we were soon so cold that after an hour and one half we started out again on the trail and kept marching until we had reached Camp Lloyd at half-past three next morning. Since early morning we had made about twenty-five miles on a bad trail, five of it under heavy packs.

Around midnight there is at this time of the year a twilight which continues for about two hours and makes traveling on smooth rocky slopes very difficult. It has been our luck to reach cliffs and slippery rocks at just that time. Some time after our arrival at Camp Lloyd the three younger Eskimos came in also.

On the afternoon of August 8th Herz, Belknap, Church and myself with the three Eskimos set out on the definite ice-cap expedition of the summer. The Eskimos with small packs started off on the trail and the rest of us in the dory towing the canoe and planning to meet the Eskimos at the Dory Landing. We arrived at four o'clock and were in bed by five. With Church and the three 


\section{NORTH POLE OF THE WINDS}

Eskimos I started out under packs at seven-thirty on the trail for Camp 2. Herz and Belknap had preceded us going in the canoe, which had been loaded down with the sled and the equivalent of about six packs of provisions and equipment. The night was still and relatively warm and the insects correspondingly troublesome.

The success of the ice-cap expedition we had long known would depend in large measure on whether we should be able to use a canoe on the braided and boisterous Watson River with its many rapids, but especially those which we had designated as the Lower, Middle and Upper Rapids. Our earlier reconnaissance had convinced Belknap that this was feasible and so this difficult and arduous task had been entrusted to him with Herz as his assistant. From the Dory Camp they set out with the sled balanced across the gunwales. After paddling about a mile they found it necessary to wade with one pushing and the other pulling the loaded canoe. In places the sand along the river was so saturated with water that first one and then the other of them would sink in a local quicksand, but finally they succeeded in reaching the Lower Rapids at about half-past two in the morning. Here the canoe was dragged into a sheltered bay and with the more valuable sup- 
plies unloaded the two men crept into their sleeping bags unrolled upon the sand.

The entire day following, the ninth, from nine in the morning until six in the evening they spent in portaging the loads past the Lower Rapids. At seven in the evening the canoe was again put in and towed until a high bluff was reached. The current was here very strong. After two unsuccessful attempts to tow past the cliff, the men got in the canoe, Herz in the stern, and both paddled hard until too tired to continue. Then a paddle would be stuck in a crack in the vertical cliff beside the river and the canoe held in position until they were rested sufficiently for another spurt. Once past the cliff the current was swift but shallow and good progress was made until they reached a big bend opposite a lake on the terrace above the river, which they reached at about half-past ten in the evening. Here the canoe was pulled out.

The river carries numerous blocks of ice and from some which were found stranded a little tea was made and a simple supper eaten. Sleeping bags were once more unrolled upon the sand and the men were soon asleep, but were up again by eight-thirty the next morning. On this third day, the tenth of August, the loaded canoe was worked up through swift water, sometimes by towing from 
the shore and sometimes by alternately paddling and pulling and pushing while wading the stream.

Here there was so much ice floating in the water that feet became numb with the cold. Once in trying to pull up between two rocks Herz slipped and was in the water up to his neck. Fortunately, the canoe seemed fast on the rocks, so Herz made for shore to empty his pockets and to protect his valuable watch. Just as he started back to the canoe it slipped off the rocks and Belknap went completely under, but as he had caught the side of the canoe he quickly came up and saw that Herz was holding the bow firmly, which prevented a tumble into the rapids below. They now proceeded very cautiously and came soon to a place where the rocks pushed out into the stream making it impossible to pass them. Here the canoe was taken out again and the remainder of the day spent in portaging the load to Camp 2, where Dr. Church was busy making hourly measurements on the height of the water in the river and on its temperature. In this way they learned that their impromptu baths had been in water at a temperature of $36^{\circ}$ Fahrenheit. Very tired they turned in early, for the first time on the trip sleeping in a tent.

The next day, the eleventh, was spent in portag- 
ing past the Middle Rapids. The day was warm and with only a slight breeze so that the flies were an especial torment. One suffered particularly when portaging the canoe as the hands were in use to balance the load. Just as they brought in the last load they encountered Erlanson on his way out to Camp Lloyd. 'The heavy work of the past few days had begun to tell on the men and was felt especially as they were making the portage on the twelfth from the river over the ridge to Sand Lake Camp. I had now joined them with the Eskimos and we took over a part of the load.

On the morning of the 13th Belknap, Herz and I started out to make the portage from the Sand Lake Camp to the river above the Upper Rapids and, this accomplished, to go on together; but now it was quickly learned that only two men can be used advantageously on the canoe except on portages, and these were all now behind us, so I went on ahead. By alternately paddling and towing Belknap and Herz made good headway until they were opposite a high cut-bank in glacial deposits where slides had taken place. Seeing a large crack far back from the edge they wisely decided to work toward the opposite bank. This brought them into the main current where with their best 
paddling the canoe began to drift down stream. Just as they were opposite the cut-bank a rumble and splash was heard behind them. Turning quickly they saw a wave two to three feet high going out from the shore they had left, where a big cave-in had occurred outside the crack. By a narrow margin they had escaped being buried under the sand.

With this incident serious difficulties of the undertaking were over, and at six o'clock in the evening they had brought the canoe and its lading to the Ferry Camp. It had been a very arduous and difficult undertaking, not devoid of danger, but it had been crowned by success. In the summer of 1928 with Stewart's help Belknap brought the canoe back the seven odd miles to Sand Lake in twenty-five minutes, though it had taken a long hard day to bring it up and both Belknap and Herz were as a result very tired.

We of the trekking party had spent the night trekking over the rocky walls of the fjord and across the several sand flats. On the 13th most of the party were at Camp 3 on the shore of Sand Lake. About midnight we were awakened by two rifle shots in quick succession followed by the cries of some animal. The marauders that had carried off the pemmican before our arrival at 
the camp had come back again, but this time two of them fell victims to the rifles of Abraham and Peter. They were blue foxes and one of the skins was in a fair condition.

Blue foxes are especially abundant near Mount Evans and in the winter season Eskimos sometimes have made the long trip from the coast by dog-sled to trap them. The skins may not be taken out of Greenland, but a small bounty of two Danish crowns, or about fifty cents, is paid by the government for each good skin which is turned in to them.

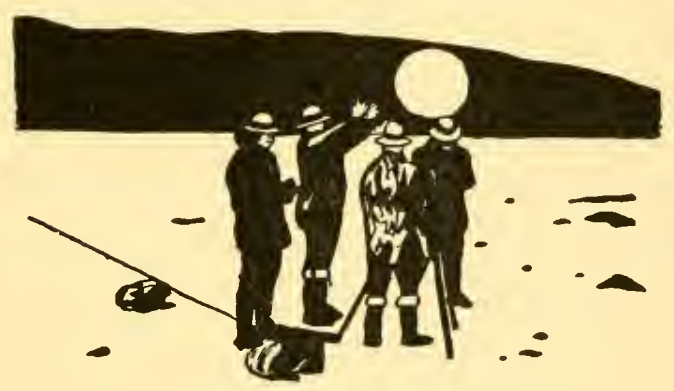




\title{
CHAPTER XV
}

\author{
ON THE ICE-CAP AND BACK TO CAMP LLOYD
}

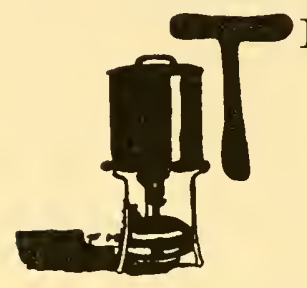

HE 19th of August we found ourselves encamped beside a small lake at the very edge of the icecap, engaged in loading our sled for the ice-cap journey. It did not take us long to discover that we had loaded the sled much too heavily to be drawn by four men on such a surface as we found everywhere about us. As a matter of fact there are but three men to pull in harness since Herz must balance the sled with the gee pole. So after a short haul we take off the sled our heavy sleeping robes, the tent, and the pack sacks filled with provisions; these Church and I now carry forward on our backs while Belknap and Herz manipulate the sled with the residue of the load. The ice is here so rough 


\section{THE ICE-CAP AND BACK}

that even though we are shod with our crampons we had made less than a mile of advance when at six o'clock in the evening thoroughly tired out we halted to camp. By three o'clock a cover of ice had begun to form on the water holes.

Heavy labor with our ice-axes was necessary in order to level off a place large enough to get up the tent, after which with use of the ice auger we set the ice-axes as tent stakes. All our available heavy objects, including the sled, were put to use as weights on the sod cloth of the tent. Our crampons, or steigeisen as the Germans call them, I had purchased from a dealer in Berlin who is a well-known outfitter for climbing parties in the Alps. These creepers were vicious looking objects armed with spikes an inch long and having the appearance of being forged. Two of the four pairs broke during the first day and the straps were constantly coming apart. This was a very serious handicap to our advance.

We have all been wearing snow spectacles of the metal type provided with slits in the form of a cross. These are excellent when the footing is good, though hardly adequate over such a dangerous surface as we were now on.

After we had got up our tent and had eaten our supper of pemmican, erbswurst and pilot 
bread, Belknap and Herz went out on a reconnaissance to find a high point on the ice at which to erect a bamboo pole for use in measuring the rate of ice flow, and further for the purpose of getting an outlook ahead for the trek of the next day. They came back and reported that the ice appeared even rougher out in advance. The second day on the ice-cap was cloudy, so that snow spectacles were not needed, and with only a light wind blowing down the ice slope. After a very arduous day we found we had advanced again less than a mile. We had risen 210 feet against 550 feet the day before in making about the same advance. Once more we smoothed off with our axes an area just big enough to pitch the tent. Church suggested that he camp on a mound of ice near the tent where he could take his meteorological observations every three hours without disturbing us by crawling over us as he got out of the tent. We agreed in chorus and with his caribou skin sleeping robe and tarpaulin he made himself comfortable since there were here no longer insects to pester us.

It begins to look as though we should not get in far over the ice unless conditions should improve. It is today the 20th of August, and with the probable date of arrival of the Disko at Holstensborg in our minds I had instructed the Eski- 
mos to go to Camp Lloyd and start in to help pack us out on the 25th. Belknap and Herz returning from setting up another bamboo pole tonight report that the conditions of ice ahead are still no better. Belknap's crampons and mine have now both broken and as we have crepe-bottomed boots which slip on wet ice we are in a serious difficulty.

An apparent dissolving of the clouds as they move in from the west toward the glacier and there meet the outblowing winds, we have noticed frequently and it appears to be a characteristic of the margin to the ice-cap.

The next day, the 23rd, we made a better advance, though we climbed only 80 feet. We set up camp number three on the ice. Today our hodometer, which is made from a bicycle wheel, broke and became useless. We recalled now that remark of Colonel J. P. Koch that the chief advantage in having a hodometer is to keep up the morale of the party. On the 22nd we had found that we were all suffering from under-nourishment and so I decided to issue two cans of pemmican for the party both morning and evening and one can at noon. Belknap set up a third bamboo upon an ice pinnacle. We decided to go forward one more trek, leaving the sled behind us, camp, set up bamboos, put up pilot balloons, and the next 
morning start on the back trail. This seems to be necessary, for there is as yet no sign of improvement of the ice surface. What we have found thus far has been very discouraging and it is largely due to the numerous earlier delays that we must now start back without our aims accomplished. We lost a week at Copenhagen, five days en route to Holstensborg and another week en route to our base. Then the labor necessary to erect the observatory on Mount Evans occupied much more time than we had expected, and to cap the climax Kallquist's accident still further delayed our start.

At the end of our advance we found a fairly smooth valley bottom upon the ice which required less axework than usual in order to get up the tent. It now begins to look like a change in the weather. Abstracts from my diary now follow:

\section{August 23}

We made a special effort today and went on without our heavy packs and reached an altitude according to our aneroids of 2430 feet at noon. I think we have advanced today from 3 to $3 \frac{1}{2}$ miles. We returned to camp and finding favorable conditions we sent off two pilot balloons which were followed to altitudes of 3000 and 4000 meters respectively, the southeast wind of the ice surface 


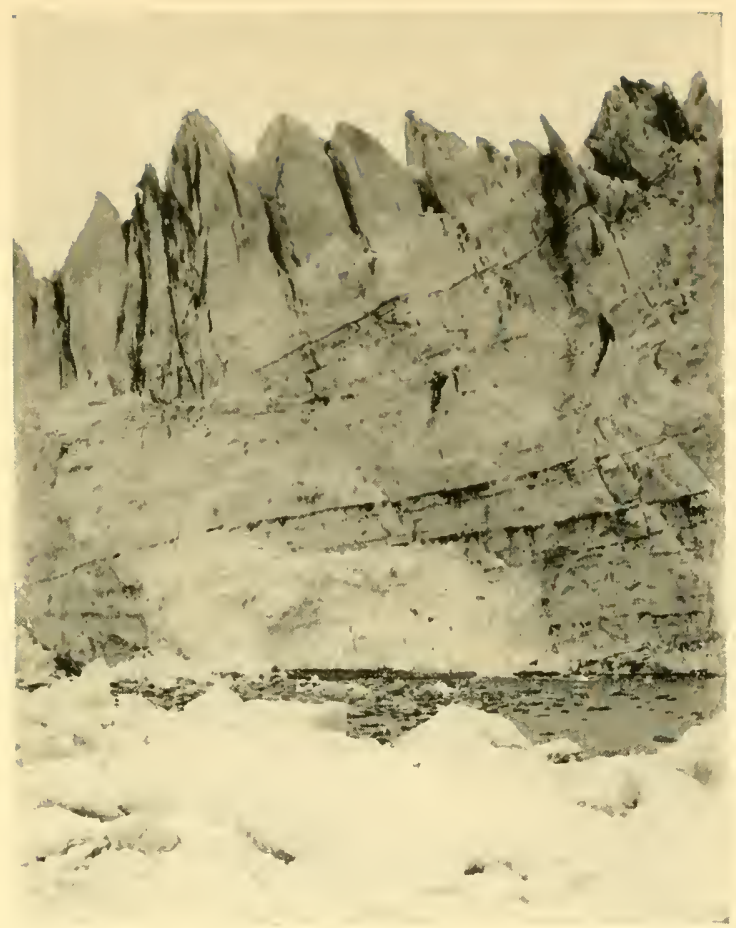

(Photo Fred Herz)

Ice-cliff at edge of inland ice, 1927

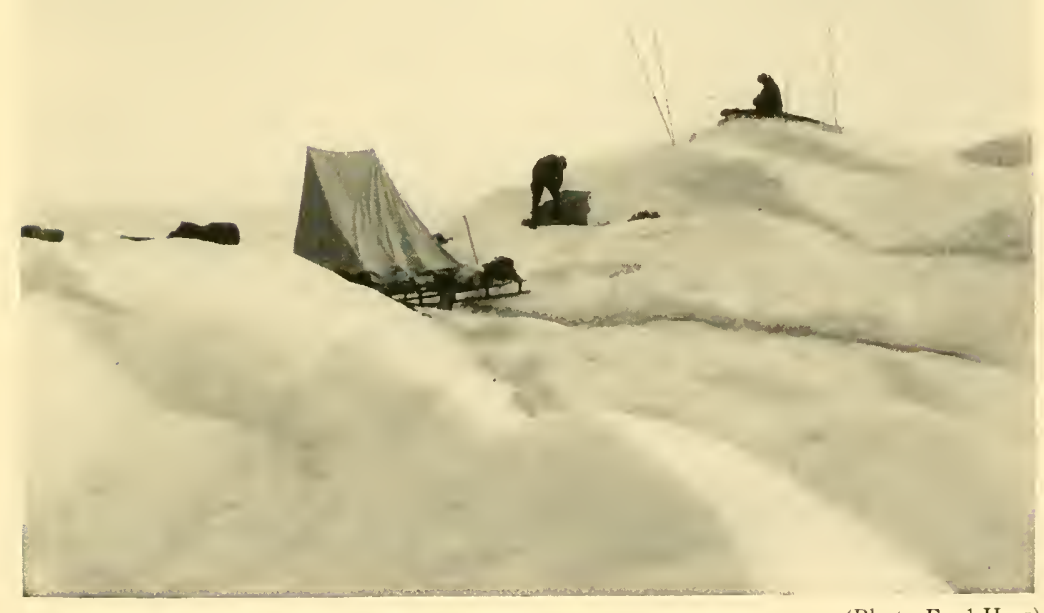

(Photo Fred Herz)

One of our camps on the ice-cap (Camp 6), I927 

holding up to these heights. The barometer is now falling.

\section{August 24}

There was rain during the night. We have calculated our food supply very carefully and must start back in this bad weather. At night we set up our tent at camp site No. 2 with all of us pretty well drenched and very cold. So soon as the primus stove was going in the tent we began to thaw out, and the savory odor of erbswurst and pemmican at once brought cheerful conditions again.

\section{August 25}

There was a fall of wet snow during the night so that the tent and ice-axes appeared covered deep with snow. The primus hummed merrily in preparing breakfast and we were comfortable. We are now only a mile and one-half from the ice border. It is bitter cold and a stiff trek is still left. Gloves become soaked and fingers cold. Crampons already badly broken we must continue to use, but the straps are now so rotten that it is impossible to repair them further. I proceed with one crampon, but it is difficult to make progress. By three o'clock, however, we are all once more at Camp 6 just outside the ice margin. Our 
pilot bread is about gone, but pemmican and erbswurst are still in sufficient quantities.

When the Eskimos were left behind us at the ice border a note was sent back by them to Camp Lloyd in which a supply of oatmeal, bacon, and a fry pan were requested to be sent in by them and brought to us here. We expect to meet the Eskimos at the Ferry Camp with these provisions and the fry pan.

\section{August 26}

The sun has come out hot and we are amazed to see the amount of moisture that appears on the soaked tent floor and in the reindeer hides. The difference in humidity between this outer zone and the ice-cap is remarked by everyone once we are off the ice. Church is getting wearied by his vigils to obtain meteorological data, for this duty has to be combined with hard packing. He will allow no one to relieve him of this work. Belknap and I are working on our notes.

\section{August 27}

Belknap and Herz have started up toward Mount Mitchell to send up balloons and to locate the secondary base line and station from which the bamboos set up upon the ice can be measured. 
Soon after they started the wind came down off the ice with a force of 40 miles per hour as measured by our hand anemometer at the camp. Under these conditions Belknap is unable to read angles and after a futile effort to do so they return to camp. We must now hurry back, as the Disko is due at Holstensborg on the twenty-ninth or later, and it is our only certain chance to get back to civilization before winter comes. I therefore start to move camp to the ferry landing where we are to meet the Eskimos. They are camped at the ferry with a note from Erlanson and Kallquist, but there is no food. The note tells us that Governor Bistrup had come in to Camp Lloyd with the Walrus on the twenty-second so as to take us out to the coast, since the Disko was reported ahead of her schedule. She was to stop on the northern trip and would reach Holstensborg on the twenty-seventh, but would not stop on the way south. Bistrup had left on the twenty-fourth Erlanson going with him, since he is to spend the winter at Godhavn. The failure to send us the provisions requested has left us on short rations, as we were later to find that our provisions cached at Camp 2, on which we were depending, had also been partly eaten up during our absence. On the way to Camp Cooley Nathaniel had shot a caribou 
calf, but the meat had gone to Camp Lloyd and had already in considerable part been eaten. It appears now that winter has already struck. The air is cold and raw and snow lies on the hills in the morning. We hurry out making the entire distance to Camp Lloyd under heavy packs and in two treks of ten miles each. On the second day we reached Dory Landing at 3:15 in the afternoon to find the tide gone out. Owing to the depletion of our stores at Camp 2 we are now without food although we are very hungry. We packed our bedding and made the additional three miles to Camp Lloyd. Belknap and Herz because of this lack of food had to come back after dark the same day and bring in the dory with the residue of our packs.

They started out in the motor canoe, but the water was so rough that it was necessary to put in to shore at the beach east of Point Emmons and there leave the canoe. They then continued over the trail and managed with great difficulty to find it in the dark. It was also extremely difficult for them in the dark to launch the dory and find all the materials for its load. They then had further difficulty in finding Camp Lloyd because of the darkness, and altogether they had a very trying night. 
We are now left in a very unpleasant state of uncertainty concerning the way we are to get back to civilization. The Disko, it was reported by Erlanson, did not expect to stop on its way southward, and there is no other boat scheduled to stop at Holstensborg. We are unable to communicate with Holstensborg except by kayakers. We have still, however, supplies to be packed to the summit of Mount Evans for the winter supply and all now turn in on this work. Kallquist and Oscanyan have not been idle during our absence and have made an excellent start.

Church now takes charge of building a balloon shelter near the theodolite stand though just over the crest of Mount Evans summit. In this position he is able to make use of the steep slope for the back of the shelter. The walls are made of sod and rock, the roof of thin bamboos in great numbers woven crosswise so as to support the load of the heavy riding sail. Heavy wire cables are now carried over the roof and are anchored to great boulders on either side. The riding sail also makes a flap door on the lower side of the shelter.

Beautiful auroras at night make their appearance with streamers and draperies. These auroras interfere seriously with our short-wave radio signals, though the long-wave signals come through 


\section{NORTH POLE OF THE WINDS}

much better. On August 30th and again on September 4th a radio message was received from the Disko to the effect that it will stop at Holstensborg sometime between the fifteenth and the twentieth of September on its southward voyage.

On September 7th I sent Belknap, Church, Herz and Peter in the motor-dory across the fjord to the Nakajanga to take photographs of the inland-ice. I was unable to go myself, but did not like to delay further getting these important photographs. They returned with excellent photographs, but as they did not return in time for supper I became quite anxious and watched for them with my binoculars. At a quarter of eight Nathaniel came to my tent to say he could hear the motor. Soon I was able to hear it also. At twelve o'clock two kayakers had arrived from Holstensborg bringing a letter from Governor Bistrup and Bangsted in which it was reported that the Disko was due the fifteenth to the twentieth of September, but he did not know whether he would be able to send the Walrus in for us. My reply went out by the kayakers next morning and Belknap and Church in the motor-dory took them down as far as the portage. The dory had not returned at nine in the evening. I prepared supper for the men and lay down in my clothes in the radio shack to 
listen for the motor. At ten o'clock Church came to report. They had run out of gasoline and so had been obliged to row the heavy dory about six miles, which had required almost two hours.

The uncertainty of Governor Bistrup's message and my reply that a boat must be sent in to us in time to get on the Disko, left us under the necessity of keeping close to camp, for the Walrus might make its appearance at any time. We have been packing to Mount Evans sufficient to employ all our time. We have also taken the opportunity to mark out a trail between Camp Lloyd and Mount Evans so that it can be easily made out during the winter when the ground is covered with snow. Along this route we have set up bamboos, steel tent poles, and other rods which will project above deep snow in such positions that they will be projected against the sky from positions along the trail. I shall arrange with Governor Bistrup to have a dog-sled come in from the coast once each month during the winter, so that directions can be sent out and any necessary aid brought in from the coast.

The $W$ alrus arrived on the twelf th with supplies and with Bangsted on board. He brought a large supply of angmagssautit, dried fish for dog food. The next morning we sailed on the Walrus and 


\section{NORTH POLE OF THE WINDS}

reached Holstensborg on the fourteenth. We were permitted to fix up our beds in the old church, the oldest building in Holstensborg and no longer in use. We boarded, however, at the Governor's. After the solitude of our camp on the Söndre Strömfjord the howling, snarling and fighting of the packs of dogs during the night, and the horns of the halibut boats calling their men before four in the morning, kept us awake in the days while waiting for the arrival of the Disko.

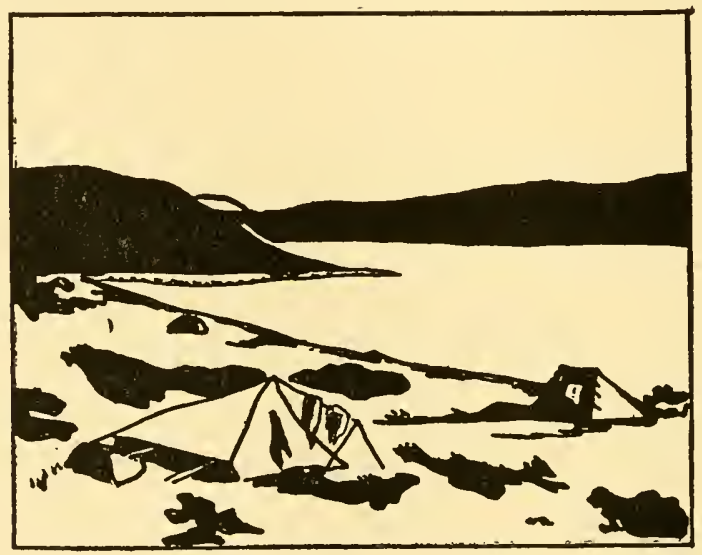




\section{CHAPTER XVI}

BANGSTED'S WINTER EXPEDITION TO THE ICE-CAP

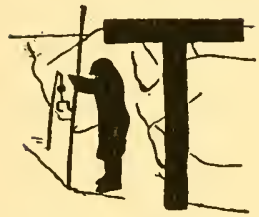

HE object of this expedition was to go in over the ice-cap by dog-sled so as to get beyond any marginal meteorological variations, and there remain as long as practicable making meteorological and other observations for comparison with those made at Mount Evans and at a secondary station in Holstensborg. The preceding winter Bangsted had gone over the ice-cap from Umanak on the west Greenland coast in latitude $71^{\circ} \mathrm{N}$. There he had found the ice surface easy to traverse with his dog-sled and had gone in about eighty miles during a period of about six weeks. Nearly half of this time had been spent on a rocky islet surrounded by the ice, a nunatak. Though not equipped with much meteorological apparatus, he had none the less succeeded in making some very 
interesting observations, and he had confirmed the experience of all other explorers that the wind throughout blows down the ice slope from the southeast. Not for an hour of the six weeks did the wind blow in toward the interior.

Church had desired to take part in Bangsted's expedition, for which his experience in winter journeys in the Sierra Nevadas of California had well prepared him.

Bangsted, who had been placed in charge of the expedition, was not satisfied with the fur suits which we had had made for our winter staff at Mount Evans. They were, he agreed, quite satisfactory for our purposes, but hardly so for a trip like this. For such an expedition great care must be taken in the selection of the skins and in the fitting of the suit, and particularly also of the sleeping bag, which should be of the best caribou skin. Snow must at all hazards be kept out of the clothing and the sleeping bag, since keeping warm in very low temperatures depends chiefly upon keeping dry.

Bangsted urged, therefore, that Church go out to the coast with us on the Walrus and be fitted with furs under his direction by David Olsen's wife, the expert Eskimo seamstress at Sarfanguak. Church is quite tired and still very anxious to con- 
tinue his studies at Camp Lloyd, but I insist upon his going out, in part because it will mean a certain amount of rest. Both men will come in together on the $W$ alrus when it brings the supplies expected to arrive on the last voyage of the Disko for the year. Sled dogs for Bangsted he ordered at Godhavn to be shipped out on the Disko when she put into Holstensborg to take the returning members of the Expedition to Copenhagen. What was, therefore, our disappointment when the Disko arrived and Captain Hansen reported that due to a very serious distemper at Godhavn no dogs had been obtainable. Bangsted now sought to assemble a team from Sarfanguak, Holstensborg and other settlements of south Greenland, and in this he finally succeeded. He chose as the Eskimo helper on the Expedition the hunter Marius, much the best man for the purpose that we have met in South Greenland, and one that we afterward employed on the Third Expedition. Bangsted's account much abridged follows:

My party consisted of Dr. J. E. Church, the Eskimo Marius and myself. My sled outfit at the start from Holstensborg in early October was drawn by eleven dogs all in good condition, handpicked, mostly heavily built animals.

So far as the conduct of the expedition was con- 


\section{NORTH POLE OF THE WINDS}

cerned I had been made the leader because of my experience in Arctic travel. The scientific work was divided with Dr. Church in such manner that he made his evaporation studies and a snow survey by use of the well-known methods devised by him, while I took charge of the purely meteorological studies and temperature measurements in the snow and within the ice crevasses. It actually turned out that $I$ also shared in the snow surveys, since Dr. Church was so injured by a fall on an ice hummock as to be temporarily incapacitated.

Our plan was to remain at Camp Lloyd until ice had formed on the fjord, when with Marius I began laying down the depots of provisions in preparation for the final start for the inland-ice. While laying down the depots we also went hunting, both to obtain fresh meat and to secure blubber for fuel. Marius and I occupied the little radio shack which had been the store-house at the camp on the Maligiakfjord in 1926. And in this hut there was no stove of any kind. We therefore heated it by an ordinary Eskimo blubber lamp.

In the fjord off Camp Lloyd there were great numbers of fresh-water seals and these we hunted in one of the canoes, and we soon had a supply for the winter. Hunting trips away from the fjord made us very familiar with the surrounding coun- 
try, which at this time of the year was overrun by ptarmigan and Arctic hares, the latter fat and juicy and especially palatable.

In traveling over the country one encounters much glacial clay which makes a dry and very loose soil. During a severe storm this soil is carried in the air and driven with great force into one's face. We experienced on these hunting and depot-laying trips some of the worst land storms I had become acquainted with in ten years of almost continuous travel in the Arctic.

By the beginning of the month of November I had so far finished my work of preparation that, accompanied by Marius, I was able to undertake the first regular sled-trip of the winter. Though the sleds were very lightly loaded, this turned out to be a very laborious trip. We took with us a two-man tent, a primus lamp with its kerosene fuel, two shot-guns, and twenty cartridges, also coffee and sugar. Our sleeping bags had been left behind, and for provisions we depended entirely upon game.

The temperatures encountered were very moderate, ranging between twenty and minus eight degrees Fahrenheit. Little snow was on the ground, and though the lakes and rivers were frozen, the ice on the fjord was still too thin to bear us. Be- 
cause of these unfavorable conditions which we could not control, daily marches were reduced to a minimum, the average of a day being about twelve miles. With a normal winter and the snow in good condition, the sled-trip from Mount Evans to the inland-ice should be the easiest imaginable.

Our course was along the south side of the fjord-head along the entended plateau of Nakajanga, thence over about six miles of ancient sand and pebble flats. In the fall of the year when this flat had been covered with a few tenths of an inch only of loose drift snow, I had described the surface as that of sandpaper, since it was extremely difficult to pull through it a steel-runnered sled. I had counted on now being able to follow the bed of the Watson River and so avoid the almost impossible "sandpaper". This was unfortunately not possible unless we were to have our kamiks soaked through, for the water in the river came up through the ice-cover and, freezing, produced an extremely difficult sledging surfacewhat the Eskimos call sarsinek ice.

After some ten days of this hard traveling I was again back in headquarters at Camp Lloyd. There was now so little daylight that it was impossible to travel with profit more than four or five hours daily. Had dogs and well trained driv- 
ers been available I should have taken several sleds, but suitable dogs and drivers are obtainable only at the Northern Greenland stations. There was now, however, no time to lose. Most Arctic expeditions have accomplished their best results between late winter and early spring. Our preliminary work had to be accomplished during the winter itself, the coldest and darkest time of the year, so as to be ready to start on the main expedition as early as there should be sufficient light. No one of our difficulties was so serious as the extreme mildness of the winter and the almost total lack of snowfall. Loads had to be reduced to the minimum in order to make any progress whatever over the bare "sandpaper" surface and the wet slippery river and fjord-ice. Instead of two sled trips, as we had hoped would suffice, no less than six were necessary before the depots were laid down, and even at that we had cut our provisions and $\operatorname{dog}$ food down to an absolute minimum.

It was well into the month of December before this was accomplished. In the meantime the traveling conditions had not improved, though the returning daylight would soon afford us a longer working day. My plan was to make our start with the coming of the new year, but this had to 
be postponed because of a violent foehn wind, which, as is usually the case, sucked up whatever snow there had been on the ground. The violent wind blew down upon us off the ice-cap, so that the temperature rose to $42^{\circ}$ Fahrenheit, and within two hours all the snow had disappeared. The ice on the fjord was quickly covered with thawwater. Under these conditions it would be impossible to set out, so we tried to be patient and waited in the hope that cold would soon again freeze a hard cover over the fjord.

On the 14th of January with Marius I made a reconnoitering trip across the fjord and along the Nakajanga to the sand flat, as a result of which I decided to break camp at daybreak the next morning. The day had scarcely ended before there had come another foehn. The rise in temperature was so sudden as to make us fairly pant and gasp for breath in the heat. The air was still, but from the southeast over the ice-cap came the dark lenticular foehn clouds which heralded the coming of such weather. We were in for another of these Greenland storms which especially characterized the winter of 1927-28. There had been two or three and sometimes four foehns each month, and each of them lasted from two and onehalf to three days. 


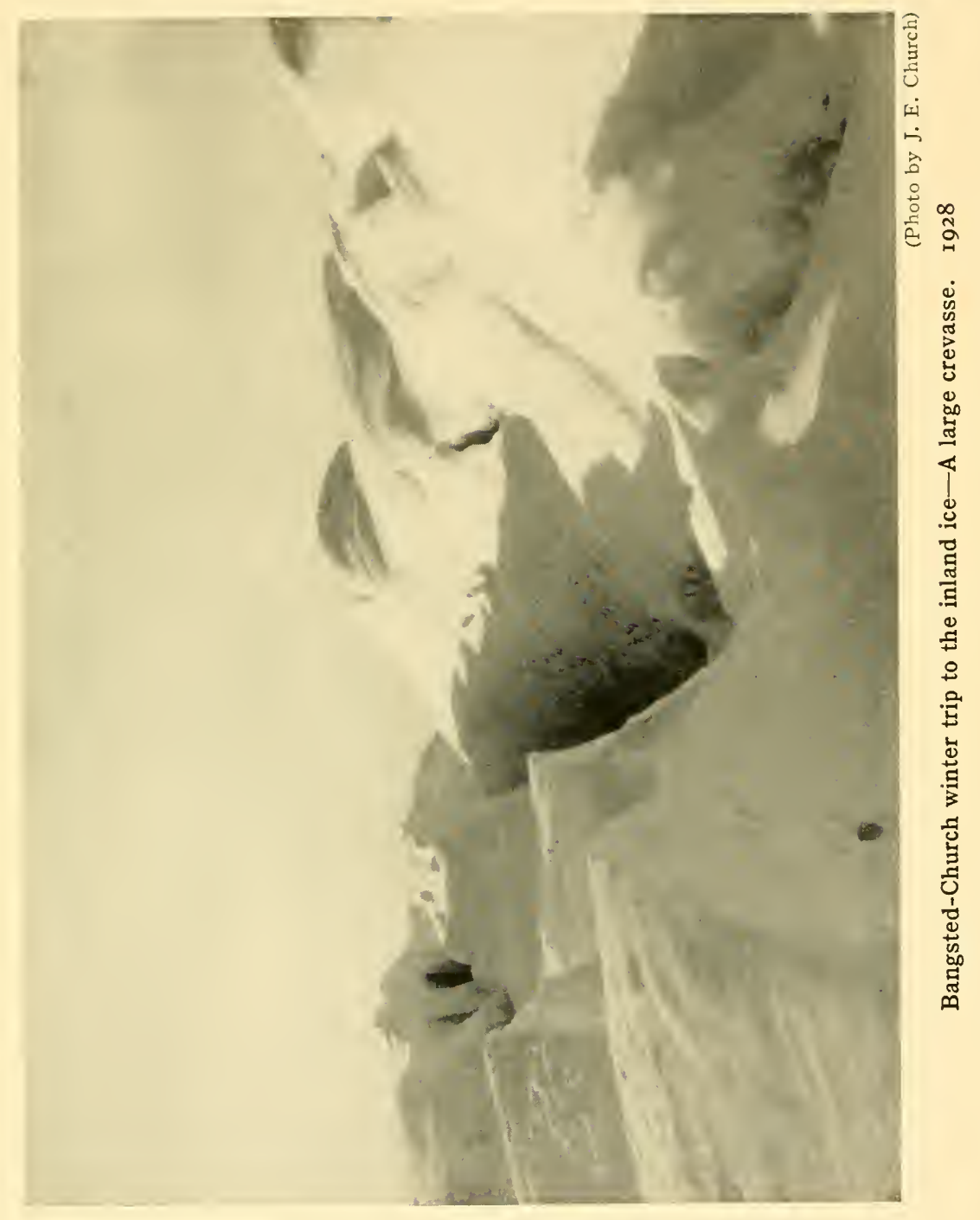



Are our hopes to be again dashed after making all our preparations for a start? No! I decided to start out and take what chance had to offer. The storm began during the night and as we turned out about five o'clock the next morning the wind was blowing strongly from the southeast off the ice-cap. Later in the day the fjord-ice was again covered with water.

Dr. Church got a start of a couple of hours while Marius and I made the last arrangements packing the sleds. During these morning hours the wind increased, but there could now be no backing out, for Church had already gone on ahead. As soon as I had made sure that everything was in order I gave the dogs the signal, and we were making a shining sled-track out across the wet fjord-ice in the dawning of the new day.

The wind was almost dead ahead. Soon violent gusts drove the sled sideways with great force. It was impossible to steer as we could not stand against the wind on the slippery ice. All our efforts had to be given to preventing the sled being smashed when it was dashed against rough ice. By noon the wind had so increased that it had reached a maximum velocity of 120 miles per hour as registered on the anemometer at the observatory on Mount Evans. It was a desperate fight for 
Marius and myself during the next two hours to save the sled. The wind had picked up the sand and pebbles from the sand flat and driven it into our faces. We were in a real sand storm. The finer sand particles penetrated everywhere. My watch, which I carried in an extra case in my bearskin trousers, was so clogged with sand that it refused to run.

We did not get away far before a particularly violent gust drove the sled with such violence against a block of ice that one of the runners was split and this forced a return for repairs. Dr. Church, who was somewhere out in advance and knew nothing of our troubles, was without food. He pushed on and took refuge against the storm in a tent frozen to the ice at the foot of the Middle Rapids of the Watson River. There he remained without fire and with scant food for three days until I, much worried about his safety, could repair the sled and join him. In the meantime the storm had blown itself out, but it had left a surface to drive one to distraction. At several places in the bed of the Watson River wide sand-dunes had been built up, and these we had to cross with the sled. Where there was ice in the river it was as smooth as a mirror. We had to carry our sleds and outfit up the frozen bed of the falls. 
When we had reached the edge of the inlandice at the one accessible place where it had been entered by the summer parties, we found the surface quite different from that with which $I$ had become acquainted farther north in Greenland. Only in the ravines of the surface was a little snow to be found. Elsewhere the ice was smooth and clear and represented a chaos of hummocks and deep crevasses. To heat the tent we made use of a blubber lamp made from a photograph developing tray and fed with seal blubber from seals which we had shot at Camp Lloyd.

Once on the ice-cap surface we found ourselves struggling forward to get in as far as practicable and there camp for as long a time as the supply of provisions would warrant. Several times my party was stopped by strong gales of wind.

In this remarkably mild winter there was not sufficient snow on the ice to make an igloo or snow house, and so the specially constructed tent was used and protected on the southeast or weather side by a wall of snow blocks supported by the sled set up on edge. Within we used the Arctic primus lamp for cooking our food. This lamp gives a hot flame by an air supply worked by hand pump and it burns about a quart of kerosene a day. 
One of the storms experienced when in this camp had a measured wind velocity of 85 miles per hour. During such a storm on some expeditions the men are accustomed to keep snug in camp. Here our most important work comes at just such times. The strong wind picks up the snow and the air is thick with snow like pea-soup. It was necessary to creep out of the tent on all fours, and get all our fur clothes wet. This is almost the worst that can happen, for in cold weather to keep the clothes dry is a matter of life and death. We slept in caribou sleeping bags, and these were spread over caribou skins, which in turn were laid on the dried grass base. Despite the cold the dogs must sleep outside. The life of an Eskimo dog is not easy. He is worked hard, has scant rations, and must later be killed for food.

During the worst storm the tent threatened to come down, and so it was necessary to dig up the snow of the floor to make blocks to prop the tent on the inward side against the roaring gale.

One day we nearly perished when we ate pemmican that had gone bad. I woke up feeling very tired. When I got outside the tent to make the morning meteorological observations, everything went black and I could hardly stand. I dragged 
(Photo J. E. Church

The "White Mountains." The inland ice hills touched by the returning sun January, 1928. Bangsted's winter camp on the ice-cap

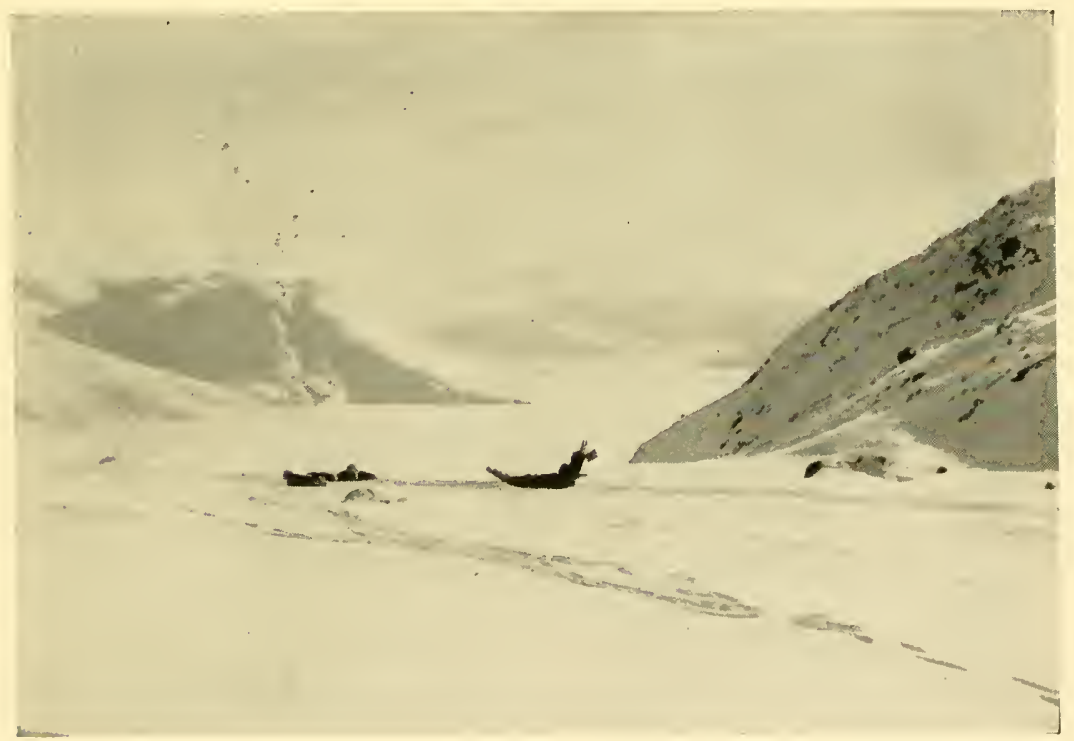

(Photo J. E. Church)

Dogsled party at rest on frozen surface of Söndre Strömfjord. BangstedChurch winter expedition to the ice-cap, Jan.-March, r928 

myself very slowly to the instrument shelter. When I got back to the tent, Marius was lying on his back unconscious and Church also was unwell. I hardly knew what to do. With no doctor you must depend upon yourself and Nature. We lay around all that day and late at night we had strength enough to get up and cook a little oatmeal and pea-soup. After eating this we felt better. The next day we were all right again.

We spent sixty busy and profitable days on the inland-ice. One of the outstanding scientific results was the evidence brought out of the rapid evaporation of the ice from the surface. The lack of snowfall was most serious on the way out, and it brought us daily into peril. The rough ice was so slippery that we were compelled to use a two hundred foot length of rope in order to let the sled and the bundles of equipment down the slope.

This return trip to Camp Lloyd we made in the month of March, when conditions were even more difficult than they had been during the outgoing trip in January. We had the misfortune to break one of the sled runners again so that it was necessary to divide the load. Our light articles were put on the sled, which was driven by Marius and Dr. Church. The remaining articles were lashed together in two reindeer skins 
and to this roll I hitched four of the dogs and myself. On slippery ice this method is quite satisfactory. I had resorted to it on the Fifth Thule Expedition around Hudson Bay in 1923. When we arrived at the Watson River we went into camp for the day before proceeding further, for we were all thoroughly exhausted. More than we had realized the constant fight against the persistent storm in combination with the rather short rations had worn us down. I was perhaps the most worn out and I now looked forward with a childish joy to the moment when we could again put our feet on land and go hunting.

On the day we left the ice we shot two hares and both had been eaten before night. I now broke camp, gave the dogs the home signal and with their tails in air they dashed down the glassy ice of the Watson River. We were driving into the light spring time.

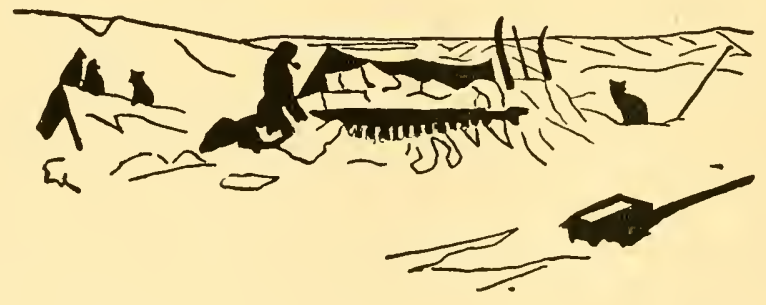




\section{CHAPTER XVII}

\section{THE THIRD GREENLAND EXPEDITION}

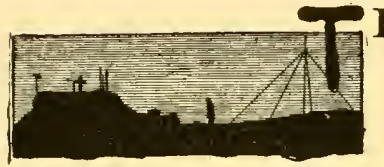

HE third expedition had for its object to take in a new staff for the aerological station at Mount Evans and to relieve Carlson, the assistant aerologist, who had gone in the preceding April and who had been carrying on alone since May 27th except for an Eskimo boy companion. It would be necessary to pack new supplies to the station for its maintenance in operation for a second complete year. I proposed also to carry out explorations and surveys, as well as geological and other studies, provided time was sufficient. Several new buildings were planned; an additional storehouse on Mount Evans, a kite house, and a new permanent tent house at Camp Lloyd.

Our freight was to be shipped to Copenhagen 203 
on May 12th by the United States of the Scandinavian-American line, though most of the expedition was to sail on the Bergensfjord of the Norwegian-American line a week later. The expedition consisted of Belknap, second-in-command, who was surveyor and geologist; Leonard R. Schneider, aerologist from Clark University; David Potter, photographer; Duncan Stewart, $\mathrm{Jr}$., assistant in geology and surveying; Francis M. Baer, radio operator; Helge Bangsted, in charge of Eskimo helpers; and Elmer G. Etes, aviator and mechlinanic.

The further passage from Copenhagen to Greenland was scheduled for June 1st on the motorship Disko. With our freight already piled on the dock at Hoboken two days only before the departure of the vessel on which it was to be shipped, a radiogram arrived from Bangsted and Oscanyan. They were together aboard the Disko outward bound from Holstensborg to Copenhagen. This radiogram advised me that the Disko was then fast in the ice-pack off Julianehaab near the south point of Greenland, and hence would hardly be able to get free and reach Copenhagen before the last of June. This arrived in time to cancel the freight shipments and the sailing of the expedition. Inquiry by cable at Copenhagen brought 


\section{THE THIRD GREENLAND EXPEDITION}

a prompt reply which indicated that the release of the Disko from the pack-ice would be wholly dependent upon the weather conditions. The ship might be freed any day, but, on the other hand, it might be held fast for weeks. A week later, fortunately, the situation had already cleared, the ship was free, and the sailing for Greenland was already set for June 15th, fifteen days later than its first schedule. Accordingly our freight was shipped to Copenhagen May 17 on the Hellig Olaf and the expedition members generally sailed on June 5 th aboard the Stavangerfjord.

The sailings of Greenland ships are apt to be set forward, and sometimes more than once. I had sailed from New York on the France on May 17th, and in Paris I received a cablegram stating that the Disko's sailing had been again changed, this time to June 17th. When the ship came into port it was found to have been so strained in the ice that repairs were necessary, so that once more our sailing was postponed, this time to the 21st of June, a full three weeks after the original scheduled date.

From Paris I flew to Hamburg, but came down at Amsterdam for lunch. As I was taking a seat in the restaurant a man jumped up with the exclamation, "Well, Professor Hobbs, where do you 
come from?" It was Captain Wilkins on his way back from a successful flight across the Arctic and now flying from Berlin to London to be knighted by King George the following day. His companion Eielson had gone up to the city so I did not see him. After perhaps 20 minutes of rapid-fire conversation we each got into our planes and flew in opposite directions. Flying as one now does in passenger planes in Europe, one is constantly meeting with explorer friends in this way.

Before leaving Paris the press dispatches had reported the sudden death in an auto-bus accident at Göteborg in Sweden of my good friend Dr. Nils Otto Nordenskjöld, a distinguished Swedish Arctic and Antarctic explorer, in whose honor the glacier tongue east of Holstensborg had been named by our Expedition in 1926. A few days later as I was flying from Hamburg to Copenhagen and was about to step into the plane, I fell in with Baron Nordenskiöld, the late explorer's cousin, from whom I learned the sad details of the accident. It had been only six months earlier that $I$ had given an address before the Geographical Society at Göteborg, at which meeting Dr. Nordenskjöld had presided and his cousin the baron had been at dinner with us. 
Because of the delay in the sailing of the Disko the freighter Skinfaxe left Copenhagen early in June with supplies for the West Greenland settlements of Godhavn, Holstensborg, and Godthaab. The Slinfaxe was a new tramp steamer of 2200 tons burden and she carried a full cargo including lumber, provisions, and 900 tons of coal. She was destined to be wrecked before discharging her cargo. On June 29 at about six o'clock in the afternoon she struck a reef about ten miles off the harbor of Holstensborg. S. O. S. calls for help brought the expedition ship Godthaab of $\mathbf{1 6 2}$ net tons, the Gertrude Rask of 378 net tons, and somewhat later the Sonja of 127 net tons, the latter a small but powerful whaling "killer ship". On the day following the wreck these vessels with the aid of motorships manned by Eskimos succeed in getting the Skinfaxe off the reef in a badly damaged condition and in towing it into the harbor of Holstensborg.

All our freight had been placed on board the Disko at Copenhagen and on the 21st of June the third expedition from the University of Michigan sailed for Greenland. On board the ship was Dr. Lauge Koch, who was planning geological studies on the fjords near Disko. On the second and third days out from Copenhagen we ran through small 
storms, especially near the Orkneys, and these held us back somewhat, but after this the weather was fine. Off Cape Farewell we had beautifully clear weather-unusual for this region-and here we skirted the edge of the ice-pack. On the 28th the radio brought us the disturbing news of the wreck of the Skinfaxe, and the following day the report of its being towed into Holstensborg harbor in a badly damaged condition. On the 30th we passed close to an iceberg about $\mathbf{1 5 0}$ feet high and later in the day during a "gray norther" many remarkably beautiful icebergs, all being borne northward in the strong current which sets along the Greenland coast. 'These bergs originate on the east coast of Greenland, along which they drift southward so as to double Cape Farewell and then travel northward to Melville Bay in northern Baffin Bay, where they cross to the west side of the bay and come southward along the Ellesmere Land, Baffin Land, Labrador, and New Foundland coasts before passing out into the lanes of steamship travel.

After passing Fiskenaesset snow-covered high peaks of the Greenland coast were in sight for much of the time. As we approached the Kugsukfjord the lofty snow-covered Hjortetakken ("Antlers"), 3835 feet, and "The Saddle", 3933 feet, loomed 


\section{THE THIRD GREENLAND EXPEDITION}

up and were landmarks seen from far out to sea. Within the harbor of Godthaab we found anchored the Sverdefiske and Sonja whaling mother ship and "killer" respectively. They had just towed in a whale. Somewhat after I had turned in for the night the boys came to me to ask if I cared to join them in a trip by boat over to the whaling ships. The evening was foggy and raw and the bed seemed just then particularly comfortable, so I declined. On the way over they fell in with a shark attracted by the carcass of the whale and with their oars and the boat-hook as weapons they succeeded in killing it. When next morning I asked for evidence of their prowess they displayed the head, which I was bound to accept as adequate.

News of the wreck of the Skinfaxe had reached us on the Disko as we were approaching Godthaab, which is some 200 miles farther to the south. The unfortunate accident, so serious for the Greenland settlements since they were, as is usual at the end of the long winter out of supplies, was also quite serious for us. Our entire year's supply of balloons was aboard the Shinfaxe, and if these were not now to be salvaged our most important scientific work would be held up. Moreover a wreck of this nature, serious enough anywhere 
is tenfold more serious in Greenland, and it was certain to make difficult our transportation problems to the base in the hinterland. I had already requested by radio a contract for the government motor-schooner Walrus to take us with our supplies and leave at the earliest moment for the Söndre Strömfjord and our station at Mount Evans. I knew that Carlson had been alone at the base except for an Eskimo boy companion, and I greatly feared that he was now out of provisions or at least very low on them. The failure of our Eskimo hunter Abraham to secure game during the preceding season had made drains on our winter supply beyond what had been expected.

On arrival at Holstensborg I found much distraction over the condition of the Skinfaxe which was lying at anchor in the harbor with her rudderpost gone and a hole punched in her bottom which was only temporarily patched up. The Landsvogel had come from Godthaab and everyone was waiting to see what disposition would be made of the cargo. An informal court of inquiry was being held aboard the wreck and questions of salvage and insurance were being discussed before the cargo could be taken off. There was but small disposition to consider under these conditions the University of Michigan's Greenland Expedition, 
THE THIRD GREENLAND EXPEDITION

and word was brought me by Bangsted from Governor Bistrup that the Walrus would be needed for unloading coal from the Skinfaxe and therefore could not be chartered as I had desired. It was added that the Governor could not even see me to discuss matters for at least a week.

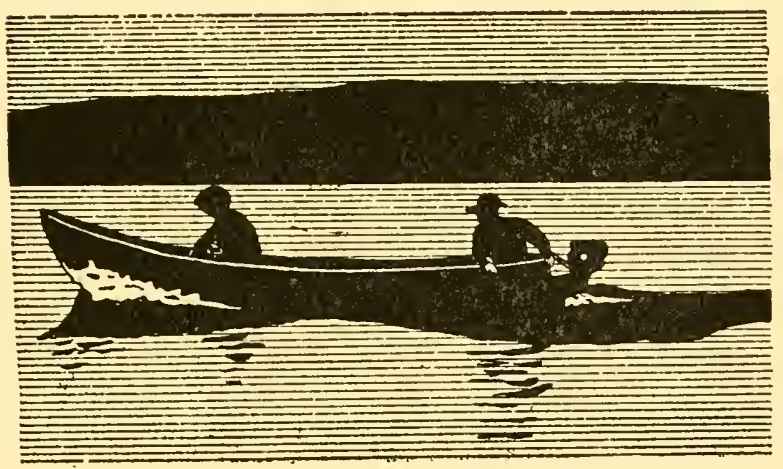




\section{CHAPTER XVIII}

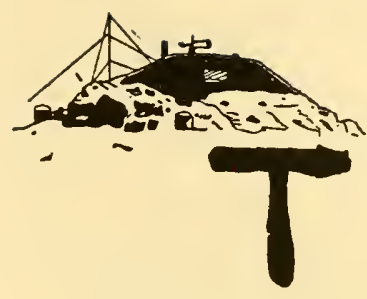

THE RELIEF OF CARLSON A'T MOUNT EVANS

HIS was a situation indeed! Carlson I feared was in serious need of relief, and I felt warranted, therefore, in forcing my way into the Governor's office where I found him in conference with the Landsvogel. Quite politely I was told that the situation was a very perilous one and that the Walrus could not be spared. 'To this I replied that I fully appreciated the situation, but that I did not need the Walrus. This caused some surprise, but I now proposed to make use of a smaller sloop, a six-ton motor vessel named the Nakuak which had been of the deck cargo on the Skinfaxe and was consigned to some Eskimos for halibut fishing. 'The boat had been injured in removing from the wreck but a very little work in repairing the injury 
would put the sloop in seaworthy condition, and this could probably be accomplished within twentyfour hours. I proposed if this could be made ready for me to select from our stores, which had already been landed from the Disko and placed in a warehouse on the dock, only those that we absolutely needed and with them sail the next day for the Söndre Strömfjord so as to relieve Carlson. "Oh", said the Landsvogel, "we thought you must have the Walrus". "No", I replied, "not at present." I will divide my party of eleven including the Eskimo helpers and take five with me on the Nakuak down the coast and up the fjord by the all-water route. If David Olsen can let us have his sloop also I will arrange to have him take on board the remaining portion of the party with a light camping outfit and have them transported as far only as Sarkardlit on the Avatdlekfjord. From there they will proceed over the winter dog-sled route in charge of Belknap.

This plan was at once agreed to, and after some further difficulties had been ironed out we were soon hard at work in the storehouse, getting out for the Nakuak such stores as she could take, and for Olsen's new sloop the light camping outfit necessary for the trip across the country. In the 
preceding fall one of our canoes had been cached on the fjord at the foot of the eleven-mile portage for kayakers, and it was my plan for Belknap's party to make use of this canoe for the latter half of the distance to Mount Evans. When the Skinfaxe difficulties had been overcome and the cargo unloaded, then, and then only, would we have the Walrus bring in the residue of our supplies.

Belknap's overland party was to include Potter, Stewart, and the four Eskimos. Schneider, Bangsted, Etes, and Baer were to go with me on the Nakuak. Through the radio of the Disko I was able to send a message to Carlson that we were coming at once to his relief. We could not of course receive any answer from him. Our message on arrival at Godhavn, the northern capital, would be broadcast by the voice of Holton Möller and picked up by Carlson at Mount Evans.

In a high northerly wind which was kicking up a heavy sea, my own party set sail a little after noon, the passengers and crew of the Disko cheering us lustily as we moved down the harbor and out to sea. A little later Olsen's sloop was off with Belknap's party, which was also loudly cheered by our shipmates and friends on the Disko.

The skipper of the Nakuak was a half-caste 
Eskimo with a heavy reddish beard and very fierce aspect, but we were pleased to observe that he knew the route and was a very competent sailor. We anchored for the night at a little bay known as Hans Egede Harbor, where we were sheltered from the high seas which were outside. Before turning in we dropped fishing lines over the side and hooked some fine cod, though many more sculpins which are good only for bait.

Schneider, Baer, and I taking the dinghy went ashore with our sleeping bags and slept under the shelter of a ledge. About three in the morning I was lying awake, and hearing activity on board could see that our skipper was getting ready to up-anchor. I roused the others and we hustled on board. We were soon off and by a protected shallow inside route behind the skerries of the coast made our way to the mouth of the Strömfjord, where we anchored for the next night. The following day we sailed up the Strömfjord arriving at Camp Lloyd by flood tide at about $4: 30$ on the morning of the ninth.

Leaving the others to begin the work of getting our supplies on shore by the ship's dinghy and our own Mullins steel boat, I made all haste up the trail to Mount Evans, as I was anxious to know how matters stood with Carlson; for owing to 


\section{NORTH POLE OF THE WINDS}

Oscanyan's throwing up his position as radio operator the station had been left without connection with the outside world since the spring of the year.

As a turn in the trail to the station brought me in sight of the hut I could make out smoke coming from the pipe chimney and I raised a loud "hello". It seemed hardly a second before Carlson and the Eskimo boy, both on all fours, came shooting through the low door. Carlson's joy at knowing that his friends and supplies were already in camp could be better imagined than described. It is no light matter to be left without contact for so long a time, and with the best of intentions, but against Carlson's own wishes, the Governor at Holstensborg had insisted Carlson should not be quite alone and had sent him a small Eskimo boy to be his companion. The boy was lazy and had a consumptive cough which in the cramped quarters of the little hut was the occasion of a good deal of concern to Carlson. As the boy had to be fed, the supplies had run low and for some time Carlson had been piecing out his provisions with ptarmigan, which had required some time to secure.

However, "all's well that ends well", and it was apparent that Carlson had managed admirably and had accomplished good results in the scientific 
work of the observatory. We started back to Camp Lloyd to find the work of unloading the Nakuak proceeding satisfactorily under Schneider's direction. Before night everything was on shore and covered against possible rain which was threatening, and the Nakuak with the boy on board had started back to the coast.

Schneider and Baer went back with Carlson to install themselves at Mount Evans and take over their duties as aerologist and radio operator respectively, the rest of us remaining in tents at Camp Lloyd beside the fjord.

On the night of the tenth, the day after landing, I had turned in at nine o'clock but was roused by Carlson at about ten-thirty. He was much out of breath and, cross country runner as he was, had made the trip down from the Observatory in twelve minutes. He reported to me that Belknap had reached the hut on Mount Evans in a much exhausted condition and with a ligament of his knee badly strained. In crossing a divide the party had run into a bit of weather with wet snow, and the tents not being water-proofed they had passed a miserable night. When Belknap had proposed to break camp and start out on the trail without waiting for the storm to abate, the Eskimos, who were without slickers, refused to go. Belknap 
with Potter and Stewart had then left them and gone on ahead. Stewart, Carlson reported, was back on the trail about two miles, done up. Potter had got separated.

While I was dressing Carlson roused Etes and hastily put some supplies into the Mullin's boat. With the outboard motor Etes and Carlson now started down the fjord while I followed along the shore some distance inland, shouting at intervals as I went. The hum of the motor in these solitudes is heard far in from the shore and would certainly be noticed by anyone not more than a mile inland. About two miles out I picked up Stewart tired but game, and signaling the motor boat he was taken on and regaled on grapefruit. After the boat had proceeded five miles further down the fjord and I had reconnoitered on shore, we all returned to Camp Lloyd.

It was now near midnight and a drizzling rain was falling. Stewart after a good meal was put to bed at Camp Lloyd. Potter I learned was packing a sleeping bag and was well supplied with food, so I told Carlson to go back to Mount Evans and suspend further search till morning. Potter is a very hardy man, inured to climbing, and was, I felt sure, quite able to take care of himself. On reaching Mount Evans Carlson found that 
Potter had already come in, but before his arrival Belknap, a good deal worried, in spite of his bad knee had gone out with Schneider in search of Potter. This made it necessary for Carlson himself to go out and bring in the search party. All were tired out but they rested the next day, only the necessary work being done. Belknap's knee had been injured in a running contest at the University, and strained as it was on this trip, it gave him much trouble later in the season. A mistake had been made in not remaining in camp despite the discomfort, and again in letting the party get separated. The Eskimos came in quietly about ten o'clock the next morning. They had followed the route planned and, picking up the canoe at the portage, they had paddled up the fjord for the last thirty miles of the journey.

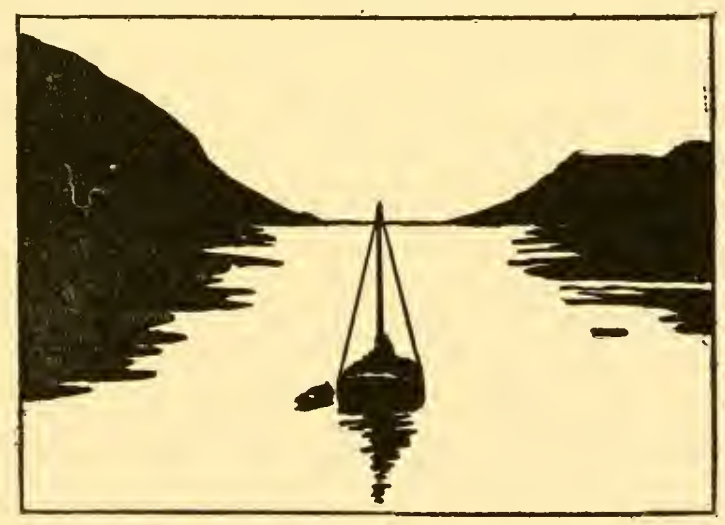

219 


\section{CHAP'TER XIX}

PREPARING FOR THE ROCKFORD FLYERS

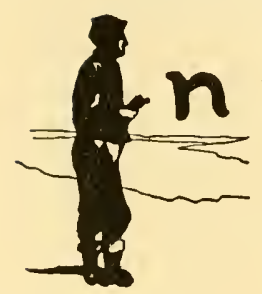

the spring of 1928 Bert R. J. Hassell, a very experienced SwedishAmerican aviator, had laid his plans to fly from his home at Rockford, Illinois, to Stockholm in a single hop of 4200 miles. Quite naturally he was unable to find backers for so hazardous a proposition. With the late William Naylor, Chief Engineer of the Stinson Aircraft Company of Plymouth, Michigan, he came to Ann Arbor to consult with me concerning the flight. I advised that he break his flight into two and make a way station at Mount Evans, pointing out to him the advantage of practical freedom from fog within the Holstensborg hinterland, and also describing the way in which the Greenland glacial anticyclone could be made to serve an aviator while crossing Greenland. 
He was much impressed with these advantages and was convinced that a practical commercial route from America to Europe could be found across Greenland.

We had several other conferences on the subject. Photographs which I had brought from Greenland showing the character of the great sand flat east of Mount Evans revealed, so Hassell thought, a possible landing place for a plane. I was, of course, glad to promise every assistance possible on the part of the Expedition personnel in case he should attempt to put through his project. Not having a technical knowledge of such matters and further not having had the matter in mind while still on the ground in Greenland, I made clear to Hassell that I could not assume the responsibility of saying that a proper landing field existed now near our station. If, however, he would select a flying man in whom he had confidence and who was also a mechanic, I would take this man on as mechanic of the Expedition and we could then send by radio an expert opinion concerning possible landing places before Hassell should take off at Rockford. This plan was agreed upon and Elmer G. Etes, an aviator and a close friend of Hassell's, joined the Third Greenland Expedition in this double capacity. 


\section{NORTH POLE OF THE WINDS}

Etes proved to be a very competent mechanic and was an invaluable aid to us in our building operations. My concern in the Hassell flight was not wholly unselfish, for I was deeply interested in trans-oceanic aviation for itself. The flight across the Greenland ice-cap could not fail to bring out valuable scientific data, and Hassell on his part promised to let me attach to his plane a special self-registering instrument to automatically record the pressure, temperature and humidity of the air throughout this section of the flight. The firm of Julian P. Friez and Sons of Baltimore, manufacturers of precise meteorological instruments, loaned the Expedition an instrument specially constructed for this purpose, and this instrument we took with us to Mount Evans.

Before the Expedition sailed the plans of the Hassell Flight had been largely perfected and a special plane was building at the works of the Stinson Aircraft Corporation. Spare parts including a landing wheel and a spare propeller were taken with the Expedition to Greenland.

'Two other flying projects were, moreover, seriously considering a flight by the same route, and in one of these Colonel Lindbergh was interested; so that altogether I gave much time to the subject. While in Copenhagen $I$ took up with the 
Minister for Iceland the matter of a suitable landing place on that island. It was, of course, highly desirable, even if not absolutely necessary, to have weather reports sent by radio from Reykjavik to Mount Evans before the take-off of Hassell at the latter place, and this involved very considerable difficulty both because of restrictions placed by the Danish authorities upon the use of radio in Greenland and because messages sent through the Government stations there require more time than is desirable or even safe in sending weather forecasts on such flying projects. In fact, arrangements were never thoroughly perfected for this part of the project.

Before leaving America in the interest of the Hassell flying project and by arrangement with Hassell and his promoter, I had written the Director for Greenland in the Danish Ministry of the Interior, the Honorable Daugaard-Jensen, outlining to him the plans and stating that our Expedition was coöperating with Hassell in giving him the use of our station with its radio and weather prediction facilities, as well as the services of our personnel. In the reply Hassell was advised to make his request to enter Danish territory in this fashion through the State Department in Washington. When I arrived, therefore, in Co- 


\section{NORTH POLE OF THE WINDS}

penhagen during the second week of June, I was at once called to the American Legation and there shown a long and voluminous correspondence by cable between Secretary Kellogg of the State Department in Washington and Count Reventlow, the Danish Foreign Minister. Hassell's application had referred to the coöperation of the University of Michigan Expeditions, of which there had already been two-those of 1926 and 1927. A long cablegram had gone back to Washington that the foreign office had never heard of these Michigan Expeditions. After several exchanges it had occurred, it seems, to Count Reventlow to confer with the Ministry of the Interior and the Director for Greenland, the Honorable Daugaard-Jensen, whereupon the discovery was made that the matter had been fully covered by correspondence.

A rather startling request was now made of me. The flight would be permitted, I was told, if it could be connected with the University of Michigan Expeditions. After first making sure that no financial responsibility would be fastened upon the Expedition, this was agreed to and a despatch was at once sent off to the State Department which supplied the permission for the flight.

In Hassell's interest and at the request of Ma- 
jor Fredericks, his backer, I had through the Director for Greenland, ordered four hundred gallons of aviation gasoline and the necessary amount of mobiloil with instructions to have this go in to Holstensborg by an earlier steamer than the one by which our Expedition sailed. Before this gasoline could be forwarded to Camp Lloyd a leak had occurred in the fuel tank at the Godhavn radio plant and this supply was at once commandeered, since the station would have been put out of commission without it. The Director for Greenland was, however, able to send in a new supply and so change the schedule of one of the ships as to deliver this later supply at Holstensborg in time. Under instructions this gasoline had already been taken in to Camp Lloyd on one of our chartered voyages of the Walrus, so that it was already stored above tide near Camp Lloyd at the time the Third Expedition arrived.

We had been so much delayed by the postponement of three weeks in the sailing of the Disko from Copenhagen, that there was now no time to lose in fixing upon a landing field. The very day after we reached Camp Lloyd, I set out with Etes and Bangsted to reconnoiter the possible landing places for planes in the vicinity. The great sand flat above the fjord might have served 


\section{NORTH POLE OF THE WINDS}

but for the fact that there are sand hummocks from one to four or more feet in height grouped about low willow shrubs, and the further fact that at the high spring tide this flat is entirely submerged. This was then a possible, though hardly a practicable landing place, and one scarcely a mile from the Dory Landing, where at high tide we could deposit the cans of gasoline directly from the dory or the Mullins boat. It was only after considerable search that the one really practicable field was discovered by Potter on a raised clay terrace which in places was covered with boulders and in places also was much gulleyed. We laid out, however, a runway about 1500 feet in length and almost perfectly flat. It was also as hard almost as cement, and at least 20 feet above the highest tide. Since the wind in this fjord depression blows lengthwise, it seems here to be unnecessary to have a wide field or runways crosswise of the valley. From Dory Landing, the head of boat transportation, it would be necessary to pack the cans of gasoline over a rather difficult trail a distance of about three miles. The distance of the field by trail from Mount Evans station was about eight miles.

Across a small canyon and about 500 feet to the eastward of this runway there is a possibility 
of laying out another which would be 2500 feet in length, but this would require removing scattered boulders, many of them quite large, and for this task a gang of men would be required.

Baer had found the radio equipment left at the station to be heavily coated with soot and quite out of commission. It was therefore, necessary to take everything to pieces and carefully clean the parts. Even after this had been done he was generally unable to get contact with the United States during the summer, but on one of the more favorable occasions he did succeed in sending out through the New York Times station a report by Etes for Hassell with reference to the landing field which we had found. Although Hassell had originally intended to take-off for Mount Evans with a sufficient gasoline supply to reach Stockholm, he had considered Iceland as an alternative stopping place. Convinced that our runway of something more than a quarter of a mile in length would be too short for the take-off with 400 gallons of gasoline, the amount necessary to reach Stockholm, Etes decided to outline in his report the length and character of the field without any verdict as to its adequacy. While awaiting the reply to this message we transferred the gasoline to the Dory Camp, but we considered it wise to 
leave it there until we should learn from Hassell of his intentions.

We now sought to improve the efficiency of our radio station by changing from direct to alternating current, and for this we installed a new motor and transformer which we had brought in with us, and in place of the thirty-five foot jointed bamboo mast we started to erect a new steel mast sixty feet in height. The erection of the mast was most difficult and dangerous. Before we had it secure it fell twice, but fortunately without hitting any of the party.

On July 17th as I was returning to Camp Lloyd from Mount Evans I noted that Point Emmons across Michigan Bay from Camp Lloyd seemed deeper in the water than I had ever seen it. Clearly a very high tide was at flood, though we had not expected the spring tides until somewhat later. I hurried down to the landing fearing trouble. The dory was just floating loose from its moorings and the oars already were in the water. The box of Burgess Batteries, which we had thought safe above high tide, was already eight inches under water. Some cans of the Hassell gasoline as well as the extra propeller for the plane were also in part under water. First rescuing the loose articles and making the dory fast, I 
roused the Eskimos and together we set to work salvaging our material. When next day he had opened up the box of batteries and dried them in the sun we found them little if any impaired, but we had had a narrow escape and a valuable lesson.

This year we have replaced our hunter Abraham by Marius, a quite remarkable Eskimo who was of Bangsted's ice-cap party in the preceding winter. We have also given the Eskimos of our party one day for hunting in each week. Owing largely to the skill of Marius, though Nathaniel and Peter are also good hunters, we now had much more game on the table, and one day they brought in fifteen geese.

Bangsted has not been at all well and is now unable to work, but is still useful as an interpreter with the Eskimos. He should be under the care of a physician, and it is arranged that he shall go out on the Walrus when it comes in with our supplies. This will permit him to depart soon for Copenhagen aboard the Hans Egede.

The $\boldsymbol{W}$ alrus arrived at Camp Lloyd on the 23rd bringing our supplies, and all hands were kept busy unloading the ship. By Etes our lumber was made into a raft and all our gasoline and kerosene brought ashore upon it. Before the last two loads were ashore the wind rose and made the fjord too 
rough for continuing the trips from the ship to the shore, but by seven in the evening the wind had died away sufficiently to get everything off and on shore, whereupon the Walrus sailed away.

The next morning, July 24, Carlson came down from the observatory bringing two radiograms from the Managing Editor of the New York Times which had been received during the night. One of these was startling enough. It read:

Hassell planning to start Wednesday morning.

Birchall

This was Tuesday.

The other said:

Hassell ready to start. Ask if landing field ready now or how soon. We trying nightly to communicate with you directly.

BirchaLL

At once all other work with the exception of the routine meteorological and aerological observations was suspended. Belknap, Potter, Etes and Stewart with our four Eskimos in dory, canoe, and kayak set out for the dory landing. Etes was to make some final improvements on the landing field and to mark it so as to be clearly seen from the sky, while the others under Belknap's direction 
were to pack the 200 gallons of gasoline and 20 gallous of motor oil over the long trail to the landing field.

On the following night I prepared the following radiogram to go to the Times:

Mount Evans, July 24, 1928.

Birchall, New York Times, New York

Amazed by the report that Hassell is planning flight tomorrow without advice from us that we are ready, or weather conditions favorable. Etes on eighteenth sent Hassell by radio via Godhavn report on landing possibilities but has received no reply. Pending reply we have suspended transport of gasoline.

On receipt of your message we have taken steps to mark landing place to set Hassell down on terrace at head of fjord north side, but hope he will await our further advice before starting. Two hundred gallons gasoline and ten gallons motor oil now within two miles of landing place and our four Eskimos have started packing today. When our direct radio fails you can reach us by commercial radio via Godhavn.

HоввS

Although we waited until 10:20 P.M., which was past our schedule hour, we failed to get connection. Godhavn put us off twice saying they had a message for us but were too busy to send it and we would have to wait till Wednesday night. About 2 A.M. another message came through: 


\section{NORTH POLE OF THE WINDS}

Hassell will hop off at dawn tomorrow if weather conditions over Canada are favorable, whereof there's every indication. His next stop after Greenland will be Iceland enabling him to take off with light load. Will flash you if weather causes postponement. Acknowledge this message.

\section{Birchall}

Then from Major Fredericks, Hassell's manager :

We are in receipt of information about length of landing field and will come at once. Please mark and watch landing field and if necessary make smoke signals. Acknowledge receipt of this message. Hassell ready to fly and start on receipt of acknowledgment.

L. H. Fredericks

And a little later:

Hassell's take-off postponed until Thursday on account of head winds.

\section{Fredericks}

Later still Fredericks requested that instead of two hundred gallons of gasoline we have two hundred and fifty gallons ready on the field. I replied that we would have two hundred gallons ready on the field the next night and I hoped to have the extra fifty gallons there by Friday noon. We were sending the Times reports on weather con- 


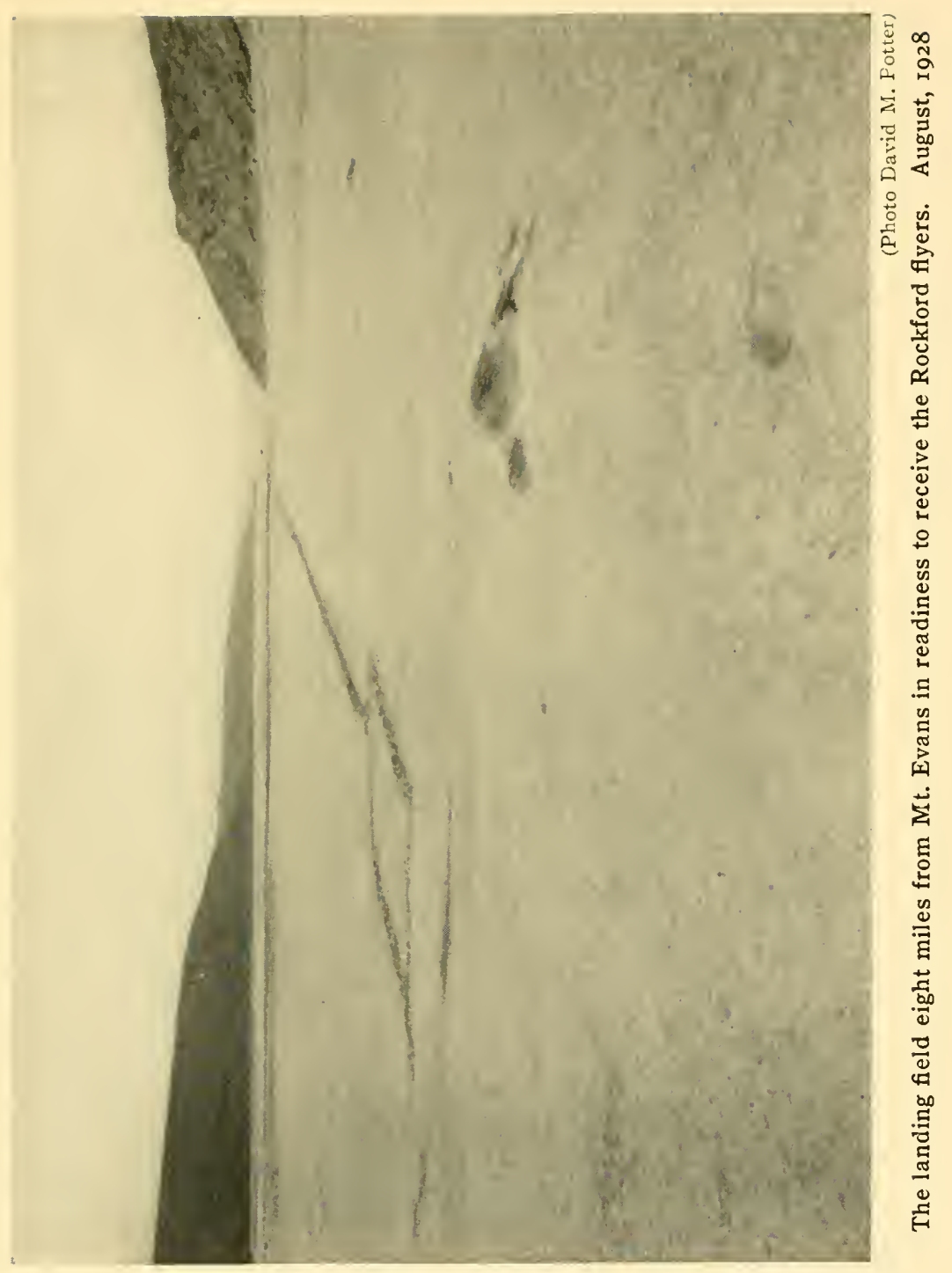



ditions. On July 26th, the day we now expected Hassell to take off, our balloon showed light easterly surface winds holding up to 1000 meters, or about a half mile, above which the wind was blowing from the southwest and south southwest at a rate of 30 miles per hour. This was most favorable for the flight to Iceland. The field is now marked and the cans of gasoline are arranged in the form of an arrow easily seen from the sky.

Etes has fixed up a small radio set and this has been taken to the Dory Landing where Schneider, who is fairly competent with radio, will communicate with Mount Evans and announce the arrival of the "Greater Rockford". A mast about 25 feet high made from two spliced bamboo poles was set up and this improvised field radio station was soon in operation. It was later transferred to the landing field itself, where a secondary balloon station was also established.

Since it was expected that the plane would arrive by the way of the fjord, and as Baer of all our company would be the only one on duty at Mount Evans and be engaged with the radio, Marius was to be stationed outside with binoculars to report the first appearance of the flyers.

On the evening of the 26th I arrived at the observatory and an hour later Marius came in from 
the landing field bringing a note from Belknap which stated that practically all of the requested 250 gallons of gasoline and the 30 gallons of motor oil had already been transported to the field by the use of a relay system which he had devised. Everyone has done splendidly, and to Belknap especially is due the successful organization of the work. We are now ready for the flyers and the gasoline transport, the field radio station, and the balloon station have by the coöperation of all hands been put through inside a period of thirty-six hours. Schneider has been calibrating the Friez meteorograph which is to be attached to the plane for the transit of the ice-cap.

At one in the morning a message came through that Hassell and his navigator, Cramer, had hopped off and been forced down and the plane damaged only five miles from the start. Then communications ceased and it was only accidentally and through the Danish News broadcast two days later that we were to learn that the plane had crashed, but that the flyers had escaped uninjured. The first news of Hassell's failure to get off was sent by note to Belknap at Camp Lloyd and by radio to Schneider at the landing field. The reguiar work of the station which had been interrupted was now resumed. 


\section{CHAPTER XX}

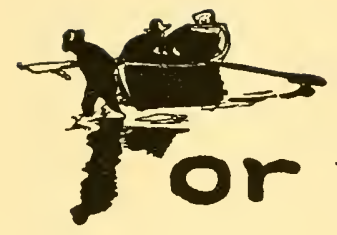

EXPLORING IN THE CARIBOU COUNTRY

the first time now that news had come of the crash of Hassell's plane, we could resume work on several projects which had been interrupted by the prospective flight. We had little enough time as it was to complete our program, and no word had been sent to us of any further plans on Hassell's part. Belknap with his assistant Stewart now started out to prepare a map about the head of the fjord and of the great flat which separated it from the inland-ice. Etes, Potter and I constructed a combined kite and storehouse at Camp Lloyd, and with the help of Schneider and Carlson a storehouse on Mount Evans.

Where Herz and Kallquist had set up their 237 
tent while building the observatory, there was a depression in the ledge which seemed to be outlined by joints of the rock so as to be nearly eight feet square and filled in with glacial deposits. Pick and shovel work soon indicated that by removing the dirt we should soon have the greater part of three walls of a storehouse formed out of rock, and we had a sufficient supply of studding, boards and heavy canvas to prepare a roof which we proposed to load down with great boulders. A door was constructed by Etes and we soon had an excellent structure which would not be moved by the strongest gales. This structure at once took in a large part of our winter's supply of provisions and further made one more reserve hut in case fire should destroy the main one. The position of this storehouse was about midway between the observatory and the shore of Lake Herz, the water supply of the station. Schneider took his bunk there so that our party was distributed at night.

In the time not needed for the station observations at Mount Evans Schneider and Carlson assembled the kites, set up the kite reel on the terrace above the radio shack, and on favorable windy days they sent up kites with meteorographs attached for study of the pressure, temperature and humidity of the upper air as high as the kites 


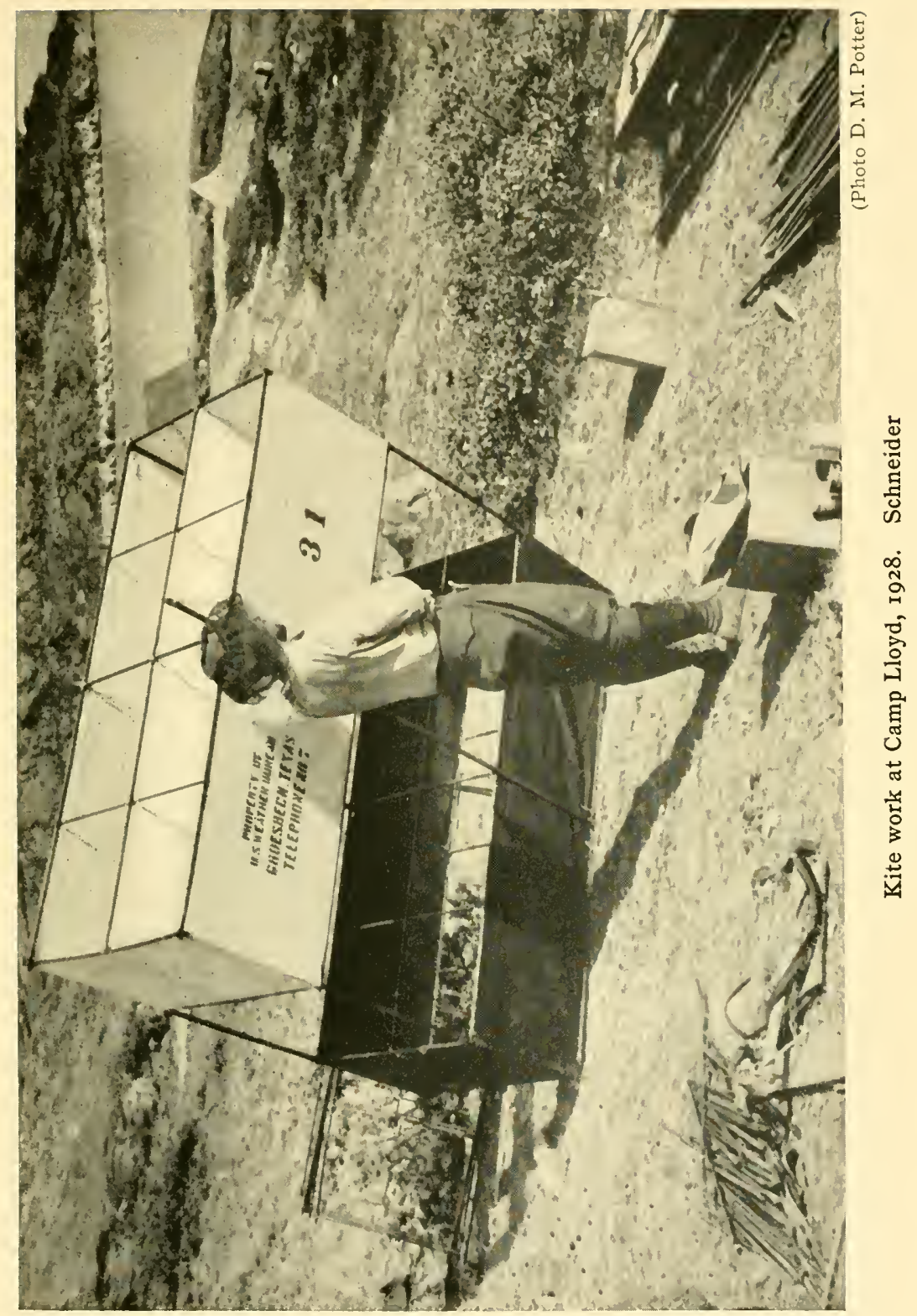



reached. Our four Eskimos were kept busy packing provisions, gasoline and fuel to Mount Evans for the long winter.

When the kite house had been completed, the cook and dining tent was fitted with a frame work of joists and boards. Etes then added one of the house doors with frame and fittings which had been purchased from Sears, Roebuck \& Co., and brought in with us. Outside the canvas walls of this tent, which were about two feet high we then built up a stone and sod wall and extended this also across the back and on either side of the front door. The back and sides of this tent-house were now lined with boxes containing equipment and provisions, and the structure thus became a semi-permanent one fitted to withstand the winter's storms.

Beside our sleeping tents we had now at Camp Lloyd three buildings; the radio shack, which had been brought in from the Maligiakfjord and had been the winter home of Bangsted and Marius, but was now used by Potter as a photograph studio, and in addition for certain stores; the kite house with store space and a bunk; and the dining and cook tent-house.

On the summit of Mount Evans besides the observatory with its two storerooms, we had the new stone and sod storehouse and in addition the 
balloon inflating shelter. This latter is useful for its original purpose during the summer time only, since the water which is used to decompose the calcium hydride for inflating the balloons with hydrogen freezes during the cold season. It is then necessary to inflate the balloons within the observatory. The shelter is, however, serviceable for storing fuel or other materials.

The country across the fjord is largely unknown to white men, though it is visited each season by Eskimo caribou hunters who come up from Sukkertoppen in their umiaks in family parties large enough to undertake the portage of the umiak across the high divides between the lakes of the district. These hunting parties remain from a month to six weeks, living on caribou and bringing out with them at the end of the season all the meat which they can carry to be disposed of at Sukkertoppen. One family has stopped at Camp Lloyd and we have been able to secure a supply of this most delicious of all meats for the winter supply of Mount Evans.

Because hunted by the Eskimos the caribou have become exceedingly shy, and they have retired ever farther and farther back behind the high ridges until they are now seldom to be found, the Eskimos tell us, until they have penetrated 
far in toward the border of the Knud Rasmussen ice-arm. The Danish Government has seriously considered maintaining herds of reindeer within this natural caribou region, now almost the only part of Greenland where the species survives. In 1924 a parliamentary commission actually visited the district and sailed up the Söndre Strömfjord on the Gertrude Rask, a government ship of 662 tons gross. This ship brought the party to a point near our base at Camp Lloyd. The commission reported against the project, although Greenland explorers rather generally, I believe, regard the plan as entirely feasible, and our own experience would confirm this view.

I had determined to penetrate this country and learn something of its character. As my companion I selected Potter, the photographer of the Expedition, who had been a student of aeronautics at the University of Michigan and had proven himself resourceful and indefatigable when trekking. Further I planned to take with me Marius, much the most competent of our Eskimos and an expert hunter.

Since we would of necessity travel on foot through this rugged country, it was necessary to set out with not too heavy packs. Each member of the party carried the three pound shelter and 


\section{NORTH POLE OF THE WINDS}

mosquito tent which has already been described (see p. 63 and head piece of chapter XIV), and also a light quilted sleeping bag of kapok. We carried a food supply sufficient for about ten days, consisting mainly of pemmican, erbswurst, pilot bread and tea. For cooking utensils we had merely a small pail for boiling our erbswurst and a folding fry pan, and each member of the party had his own cup and spoon. To Marius I loaned my Winchester repeating rifle, and Potter carried a Mauser belonging to Bangsted. For our surveying work we carried aneroid, compass, a 14 inch plane table and a ruler alidade.

Shortly after noon on the 8th of August Potter and I with the supplies were taken down the fjord in the Mullins motor-boat towing the canoe behind. Belknap was handling the motor and bring. ing Stewart with him. Marius had already gone on ahead in his kayak. The surface of the fjord was rough, but Belknap steered near the shores wherever possible, with an eye to getting on shore if we should be swamped. The gusty winds on the Greenland fjords often come without warning and for small boats these waters are very treacherous, as we had learned during the first season when Gould and Belknap so nearly lost their lives by drowning. 


\section{EXPLORING IN THE CARIBOU COUNTRY}

I planned to examine the head of the first bay on the fjord west of the upper fork (Monroe Bay) for a starting point, and it took us about two hours to reach this point. 'This bay offered a good camping site and a promising opening into the hinterland. It was supplied with a stream of icy cold water. A little beach beneath a steep bank supplied a landing place. As we approached a large flock of ducks went up from the mouth of the brook and afterwards some geese also. The canoe with the kayak we cached at the landing, since we were intending to use them to get back in case it was not possible for the motor-boat to come for us. Our supplies once safely on shore, Belknap and Stewart started back in the Mullins boat and were soon out of sight beyond the point.

The clouds were gathering and indicated rain, but $\mathbf{I}$ found time to make a reconnaissance to the south as soon as we had our camp made, while Marius and Potter set out after game. After a while Potter came back with a gray goose which he had caught in his hands, and this was served for our supper. Some fat white hares are seen on the slope east of our camp and give the impression that there is a considerable amount of small game about.

Toward evening it started in to rain and a drizzle 


\section{NORTH POLE OF THE WINDS}

fell throughout the night. At seven the next morning I was up and sent Marius out after ducks since I had seen them about the head of the bay. In a half hour he came back with no ducks but with a large loon which he had seen in a low willow shrub, and by simulating the call of the loon had lured out and clubbed to death. Soon it was raining again and we crept into our tents. In the afternoon there was a lull in the drizzle and we made a reconnaissance as far as the high divide south of us and between four and five miles distant. We were driven in by rain which continued during the night, so that by the morning of the tenth a half inch of rain had fallen since our arrival. It had already been expected that this shore of the fjord possessed a much more humid climate, for we have of ten looked out from the observatory on a bank of convectional clouds rising on this shore when anticyclonic weather prevailed on the north bank. This observation of greater precipitation was to be confirmed by our later experience. Although the tundra of the north bank is nearly always dry, here we found the ground generally wet and spongy.

We broke camp this morning leaving, however, a cache of food in a two-man tent brought for the purpose. We took a general southerly course 
along a faint trail of caribou hunters which keeps near the brook and follows a series of beautifully formed coast terraces extending up to an elevation of 970 feet. At about 1200 feet of elevation the trail passed over a divide and we looked out on a beautiful picture in the center of which lay a lake probably forty miles long extending to the eastward under frowning precipices. Far down the lake rose a striking peak of unusual form which we named the "Nipple", and farther on another toward the inland-ice which we named "The Battlement". We went down to the shore of this lake, which is at an altitude of 1040 feet, and coming back up the slope camped at six o'clock on a small lake some 200 feet higher up. Here after we had our supper of erbswurst, ducks settled on the lake and Marius succeeded in shooting three. The large lake we named Lake J. P. Koch after the splendid explorer who accomplished the wide crossing of Greenland in 1913.

The next morning, the eleventh, we continued southward to the shore of the lake of which a long arm goes off to the southwestward. This arm we followed keeping well above it on the slope and setting up our plane table for sights at frequent intervals. Toward midday we halted and Marius was sent down to the lake for water while Potter 
and I climbed the slope for sights. Potter at an elevation of about 1400 feet was able to get an important sight of the Pingo, the dominating peak over 4300 feet high which lies to the northeast of the Maligiakfjord. On the afternoon trek the sun was very bright, and on reaching a fine spring under a rock I decided to make camp, as we had already made about ten miles under pack. My plan was to start out in the night when the heat would not trouble us. We had seen caribou spoor and Marius was now sent out with the rifle.

Potter and I slept until five-thirty next morning when I roused him. Marius did not get back until seven o'clock, having seen no signs of caribou. Later we were to wonder at his amazing keenness for signs of game, the hall-mark of the experienced hunter. We continued our trek to near the end of the lake, but turned in early. The twelfth was Sunday. At midnight I was awake and looked out. One bright planet was visible and the moon shining. At two A. M. I roused the camp and began to get breakfast of erbswurst and pilot bread. We were off at three-ten as beautiful red stratus clouds were in the east where the sun was soon to rise. The temperature was $52^{\circ} \mathbf{F}$. It was a trek of about five miles, for much of the way through some very boggy wet tundra before we 
reached the outlet of the lake. Just before reaching the end of the lake a flock of ptarmigan was flushed and by some waiting Marius was able to get seven, all of which went at once into the cooking pot. We have been keeping down our rations to a low limit and are now very hungry.

Here there is a fall of about 50 feet, half of which is in one chute, and strong rapids continue below extending to a small lake about three miles distant. We had followed the lake shore in the hope to be able to get across and explore the country beyond, which appears high, and caribou hunters tell us there are two more great valleys occupied by long lakes before the Knud Rasmussen ice-arm is reached. I am most anxious to get across, but can find no practicable place.

If we had a boat we could go down to the lake and cross there, but the rapids are deep and very swift with rocks in the channel. Marius shakes his head and says, "No"! After some hours spent in reconnaissance, we have a meal of pemmican and make camp near the outlet. Bad weather is again threatening. During the night it rained, but on the morning of the thirteenth the barometer was rising and the sky clearing. Potter and I climbed the mountain northwest of the outlet. From the summit at an elevation of 2654 feet, though the 
visibility was bad, we nevertheless got views of the white surface of the ice-arm to the south and of Monroe Bay where we had started in. We can also follow the course of the outlet stream from Lake J. P. Koch by bits of river shining like silver and in the course of valleys till the river apparently turns northward and enters the fjord at the next indentation of the south shore known to the Eskimos as Angujârtorfik. We then went across a saddle in a direction about southwest to another peak which had an altitude of 2280 feet and which I named Bangsted Mountain. We then took a course across the high country northwest from the lake so as to intersect our trail coming in. Much of the way we traversed wet boggy ground with caribou spoor which had been left some hours before. Marius kept in advance with my rifle, but though we found many fresh tracks and spoor no animal was seen. We continued trekking until eight o'clock in the evening, when we made camp near a spring at a high level where the aneroid read 2060. All turned in very tired at nine o'clock with the wind blowing so hard that we had found it necessary to pile heavy stones on the tents to anchor them. At four o'clock the next morning it began raining, and just as the sun was rising through a little layer of clear sky but with dark 


\section{EXPLORING IN THE CARIBOU COUNTRY}

heavy clouds above it, a beautiful double rainbow was seen. It rained and blew until noon. In spite of the heavy weights my tent was blown free, but lying on my back I held on to the sides until Marius, who was already up fastening his tent, brought still heavier rocks to anchor it again. In the afternoon we set out to go to our first camp on the in-trail above the base of Monroe Bay, but we went too far south. The southwest wind blew so hard that we could just make our way against it. Purple foehn clouds were in the sky and these first billowed up from the southwest, these clouds coming clearly from the Knud Rasmussen ice-arm. We reached Camp 2 in the late afternoon and at once went into camp.

It was evident that a still harder blow was now coming on and so all of us at once sought protected places at which to set up our tents or at least to crawl into some protected nook. I was able to find a niche in the rock wall, in reality a sloping ledge with an overhang. With some cleaning out it was found to be just large enough, so with stones and turf $I$ built a wall shelter at the southern end and I climbed in. Potter and Marius decided to set up their tents on the lee side of the ledge. During the night the wind blew with velocity estimated to be $\mathbf{1 0 0}$ miles per hour. I had found room 
for my water-proof duffle bag on the outside of my perch, and despite the wind and driving rain I was able to pass a very comfortable night. In the morning there were ducks on the little pond near this camp and Marius with my rifle killed eight, usually shooting the heads off. All the afternoon was cold and drops of rain were falling. I had now decided to send Marius down to the base camp on Monroe Bay to go in his kayak to Camp Lloyd with a note to Belknap. Belknap is to come for us with motor-boat and, according to the conditions, we will either return to Camp Lloyd or go up the fjord and penetrate from its southeast arm to the other end of our big lake which I am to call Lake J. P. Koch.

After Marius had left us we broke camp and started down toward the divide between Monroe Bay and the lake. We found the faint trail on the lowest part of the divide where the altitude by aneroid was about 1200 feet. We then climbed a mountain northeast of this point (elevation 1800 feet) to take sights and photographs which are to be used in the map (see map on cover). We then started for our base on Monroe Bay. We were already out of pilot bread and were glad to come back to our food reserve for fuller rations. At four o'clock in the afternoon and much be- 
fore we expected him Belknap was seen coming up the bay in the Mullins boat. He had startling news, and we got off in half an hour. As the water was fairly smooth we were back in Camp Lloyd at five-thirty. It was, however, low tide and we were, therefore, compelled to land far to the west of our usual landing place.

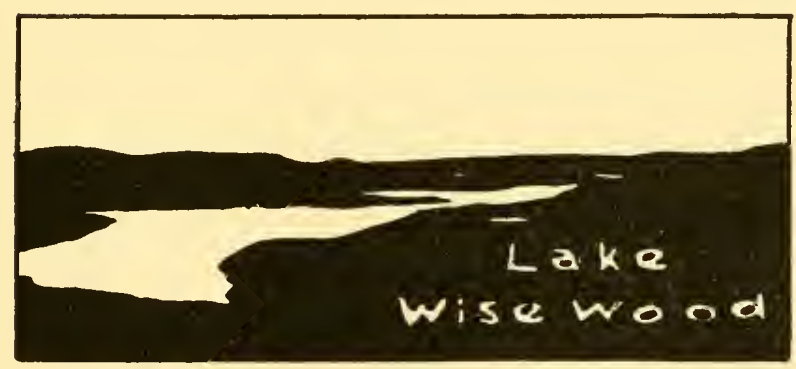




\title{
CHAPTER XXI
}

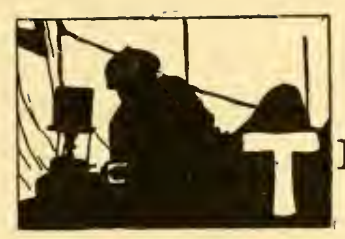

\section{THE SEARCH FOR HASSELL}

\author{
AND CRAMER
}

HE preparations for the coming of the Rockford flyers, and later our efforts to solve the mystery of their disappearance into the solitude of Greenland, were several times upset by the difficulties of securing contacts through our shortwave wireless plant. We were carrying out changes in the plant itself to render it more effective. These put the plant out of commission for considerable periods, and even when working the long hours of daylight at that season of the year constituted a continual handicap.

After Hassell had crashed on his first take-off at Rockford, we had learned through the Press broadcast that his plane was badly damaged. By radio we had asked the New York Times whether 
Hassell had plans for a new flight, but we were unable to get a reply. Later it developed that Hassell through the Times station had asked us a question but it had not come through to us. The Times, as they later told us, had tried to reach us every evening at 7 o'clock, whereas during early August we began to have radio reception at about 10:30 o'clock, and transmission was possible only between 12:30 midnight and 3 or at most 4 o'clock in the morning.

On the 14th of August, however, we secured contact with the Times, and once more were startled to learn that Hassell would take off on a new flight the next morning. We were asked why we had made no reply to a query sent us on the 6 th, for the Times seemed ignorant of the fact that we had not received their messages.

When this message now came through to us only the station staff consisting of Schneider, Carlson, and Baer were at our base. Potter and I had been absent and were still away on an exploring trip to the southwestward beyond the fjord, and Belknap with Stewart was away on survey work somewhere between Camp Lloyd and the inland-ice border. Carlson is a cross-country runner and a letter man at the University. He at once set off with the Eskimo Nathaniel following the trail along the 


\section{NORTH POLE OF THE WINDS}

fjord in a search for Belknap. By good luck he quickly came in touch with the survey party and returned with them to Camp Lloyd just at the moment that Marius was seen coming up the fjord in his kayak bringing my note. This coming together at Camp Lloyd was most opportune. Quickly attaching the outboard-motor to the Mullins steel boat, Belknap started down the fjord alone to bring in my party, and so we were all back in Camp Lloyd within twelve hours of the receipt of the message from the New York Times.

Packing my sleeping bag I at once started for Mount Evans, where shortly after midnight a message from Birchall of the Times informed us that Hassell had taken off as intended the morning before (Friday) and had reached Cochrane in Ontario at 12:15 P.M. the same day. Another part of the message seemed hardly credible, for it stated in conclusion that "Hassell should be expected in Greenland about midnight Friday", that is to say, a little before the message was received.

I hastened to reply:

Hassell has chosen the worst time for landing here if this is to be midnight of our time, the darkest hour. As I am writing at 1 o'clock the combination of hour with the almost completely leaden skies of heavy clouds 
makes it impossible to see such markings as are on the field or objects on land generally. The broad surface of the fjord can be followed of course, but land levels and land objects will not come out clearly before 4 o'clock our time, 2 o'clock Eastern Standard 'Time.

In another message it was explained that the landing field was ready with the fuel and oil in place for rapid servicing of the plane; and that a field radio station and a balloon station for reports on the upper-air would soon again be in operation upon the field.

It was of course most unfortunate that just now the weather should be somewhat unsettled. Upon July 26, the date of Hassell's first take-off, until Saturday, August 18, when he took off from Cochrane, a period of more than three weeks, the weather had been perfect for flying, and a period almost as long was soon to follow. The fact that radio contact ceased an hour or more before the hop-off from Cochrane would occur, left us for two successive days in uncertainty until the evening, when word would come in that weather conditions in Canada had been unfavorable and that the flight had been postponed. Our only course was to assume on each day that the hop-off had occurred as predicted, and we would make the weary journey to the landing field eight miles distant from Mount 
Evans to there await the coming of the "Greater Rockford". Had we realized in advance the postponement which would occur we should have taken more supplies with us. We had provided no sleeping accommodations on the field and after dark would make our toilsome way down the trail to the Dory Landing and thence in dory, canoe, and kayak nose our way in the dark past the headlands down the fjord to Camp Lloyd. There we would snatch a few hours of sleep before starting out on a repetition of the program the following day. Since our field radio station had been set up it had been no longer necessary for me to remain at the observatory close to the radio throughout the night hours.

The plane took off at Cochrane some time after noon of Saturday, August 18th, but confirmation of this reached us only late in the evening through a relayed message to the field. The runway had been marked out with lanterns, and a brush pile on the ridge above stood ready to kindle when the flyers should come into sight or within hearing. We kept vigils throughout the long night and as it grew colder through the midnight hours we huddled about a small brush fire built under a rock above the landing field and there watched until the night wore away. As soon as it was again 
light enough to see, a pilot balloon was sent up from the field to learn the nature of the winds aloft. These proved to be excellent. Light surface winds were blowing from the east off the ice-cap, which would make landing on an east-west runway especially easy. At an altitude of a thousand meters and more strong winds from the south to the southwest were blowing, which would be in Hassell's favor while continuing his flight to Iceland.

Outside the observatory on Mount Evans Marius was keeping watch with a pair of Mirakel binoculars, scanning the western sky for the coming plane. When it was six o'clock we looked hopefully for the plane to make its appearance at any moment. When no plane had appeared and it was already ten o'clock we began to have doubts of Hassell's making it. We now began to fear the worst, that engine trouble might have developed, or that the plane had gone off the course and had been lost. Our anxious forebodings now oppressed us and a portion of the party started back to Camp Lloyd and Mount Evans. With Schneider as field radio operator and Potter, photographer and general utility man, I remained on the field until after four o'clock in the afternoon, when we also became convinced that the flyers had met with disaster. 


\section{NORTH POLE OF THE WINDS}

Sick at heart we now started back to camp. We had had little sleep for two days, and depressed over the outcome we took up our packs and toiled over the eight miles of rough trail to Mount Evans.

As we reflected upon the probable position of the flyers we came to the conclusion that they had most likely been forced down somewhere in the Sukkertoppen hinterland, a vast, rugged, unexplored wilderness of incised plateau, lakes and river which lies to the southward of us across the great fjord. When the first message of the flight had reached our station on the fourteenth, I had been exploring in this region with Potter and Marius, so I was somewhat familiar with the conditions which they would encounter if they were still alive and trying to make their way out. They were, I knew, provided with the only map of the general outline of the region, and they were supposed to have warm clothing, a rifle and some provisions. We had found many ducks and geese, though these birds were now about to leave for the south. There were also arctic hares and an abundance of ptarmigan. Back from the fjord were caribou, though these were very shy. There was fresh water to be had almost everywhere and blueberries were abundant. The prospect was by no means a hopeless one. 
I was notified through the Times radio that the Danish Government was being asked through the State Department in Washington to search for the flyers. This request of the State Department was forwarded from Copenhagen to the Greenland authorities, who were instructed to begin the search with all the means at their disposal. The Danish Government went to much trouble and expense in the search which now was put on foot. The larger ships on regular sailings went out of their courses to scan the coast; the motor sloops and schooners belonging to the local governors, in the coast settlements, boats generally of a few tons each, were sent to scout up and down the fjords which indent the coast, and in some cases Eskimo runners were sent inland to communicate with camps of caribou hunters.

Dr. Knud Rasmussen, the famous Arctic explorer, was at the time on his motor schooner, the Seekonung, which was lying in Holstensborg harbor and was on his return from his Eskimo colony at North Star Bay. Neglecting his own interests he started out in search of the lost flyers and he used his wonderful prestige with the Eskimo people to organize the search. Landsvogel Peterssen as head of the civil authorities in Greenland was most active and $\mathrm{I}$ received from him frequent radio 


\section{NORTH POLE OF THE WINDS}

messages with reference to the search. Our greatest handicap was the slowness with which news traveled over the Greenland radio network and especially between our station and that of the Landsvogel at Godthaab. A favorable circumstance was the wrecked Skinfaxe lying in the harbor of Holstensborg, whose radio plant permitted communication with Holstensborg in both directions through Godhavn station.

Belknap with Etes and Carlson proceeded in the motor dory to scout the south shore of the fjord, and at a point in sight of Camp Lloyd, though six miles distant, to set up a signal flag and leave a cache of food with a canoe, tent, lantern, matches, etc. It had seemed to us that Hassell and Cramer if they were down in the region beyond the fjord would probably come out to this point, as was afterwards to be proven, for it was just there that they were found and rescued. A letter of instructions left with the cache stated that lights would be displayed nightly on Mount Evans and they were asked to signal in reply with the lantern. Potter was sent to the inland-ice border to reconnoiter, while Marius, our Eskimo caribou hunter, was sent in his kayak across the fjord to travel southward in the unexplored country for a four-day period scouting and looking for any Eskimo hunters who 
might still be there, and if he found them give them news of the loss of the plane and enlist their help.

On Sunday morning, August 19, at about 10:30 the "Greater Rockford" plane carrying Hassell and Cramer had appeared out of the fog overhanging Davis strait and had circled about over the little Eskimo settlement of Fiskenaesset near latitude $63^{\circ}$, just as the Eskimo people were on their way to church. A report of this incident was sent to us at Mount Evans through the Godhavn station and reached us four days later. The plane had circled low so that everyone in the little settlement was able to see the binoculars in the hands of the flyers and make out the wires operating the tail and ailerons. A little later I received a radiogram through the New York Times, which came to us over the Times News broadcast also, that the plane had also been seen over Julianehaab, which is in extreme south Greenland. This report was shown later to be that of the Fiskenaesset appearance which had gone out to the world through the Julianehaab chief radio station without clear statement of its origin and which of course gave the impression that the plane was over Julianehaab. If the plane had really appeared there and had come down in the vicinity and not 
been found soon, there was not a chance in a thousand that the flyers could be rescued.

Before we gave up the search completely, I again sent Marius, this time with Potter, across the fjord to combine an exploration of the eastern end of Lake J. P. Koch with a continued search for evidence of the flyers. We however withdrew the canoe and the supplies from the cache on the south shore, as we of the summer party were expecting to leave Camp Lloyd in a few days on our return to civilization.

We now set to work to as far as possible complete the packing of supplies for the winter party. Through the Skinfaxe radio at Holstensborg we had now been able to engage the Nakuak to come in so as to take us out to the coast about September 4th. Once in Holstensborg Potter and I expected to go northward on the Disko before returning to Copenhagen and I was planning to arrange transportation for the remainder of the party by small motor sloops to Ivigtut and have them proceed from there to Philadelphia on one of the boats of the Pennsylvania Salt Company. 


\section{CHAPTER XXII}

THE RESCUE

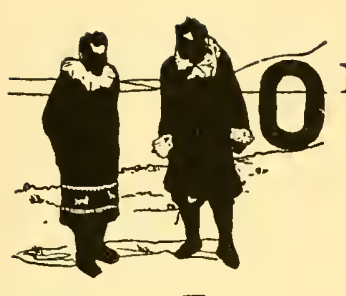

$\mathrm{N}$ the second of September, 1928 -an outstanding date in the annals of the University of Michigan Greenland Expeditions-we were hard at work preparing for the long winter by packing supplies up to Mount Evans. Only Schneider, Carlson and Baer, who composed the regular staff, occupied bunks in the observatory hut on Mount Evans. The rest of us lived in tents at Camp Lloyd, but as Belknap and Stewart were now working on the Mount Evans section of their map, they were temporarily housed on the summit, though Stewart was spending the day at Camp Lloyd.

At Camp Lloyd a high wind was blowing from the southerly quarter and the waves sweeping in 
on this lee shore threw up high breakers at the landing beach. I was thankful that there was no call to launch a boat in these waters, the treacherous nature of which we had had many opportunities to know.

Hassell and Cramer we had now given up for lost since the persistent clear statement had come in radiograms from the New York Times stating that the plane had been seen over Julianehaab in far southern Greenland. There was, therefore, no reason why we should not proceed according to our plans and go out to civilization by the last vessel before winter set in.

We were now expecting to leave the station within a few days on the Nakuak, so as to make connections with the Disko on which two of us would proceed northward and the others down the coast to Ivigtut so soon as transportation could be found. Dr. Morton Porsild, the distinguished botanist who is in charge of the Danish Arctic Research Station near Godhavn in North Greenland, had invited me to be his guest in an inspection of the glaciers and icebergs of the Jakobshavn district, and I planned to take our photographer, Potter, along with me. By special concession permission had by the Danish Government been granted for Belknap, Stewart and Etes to sail on 
the freighter Wagland carrying cryolite ore from Ivigtut to Philadelphia, though this required a trip of 400 miles in a motor-boat along the rocky Greenland coast from Holstensborg to Ivigtut, a coast skirted by reefs and without a beacon of any kind.

The observatory staff had invited the departing members of the Expedition to a farewell dinner at the observatory on the evening of September 2nd, and an alluring menu was anticipated. Rumor had it that a pie had been achieved, and so it happened that in mid-afternoon I was carrying a pack along the trail, as we all did when climbing to the observatory as a means of getting up the supplies. Stewart and Etes were still at Camp Lloyd but expected soon to follow me.

When less than half way to the Observatory I suddenly stopped dead in my tracks, for the unmistakable hum of an outboard-motor came to my ears. The sound proceeded from under the cliff near the Camp Lloyd landing, and it must indicate that one of our two motor-boats was venturing out in this heavy sea. Soon the Mullins steel boat could be seen as it got out so far that the bank no longer hid it, and there it rose and fell like a cockle shell in the great waves. "What", I demanded of my startled intellect, "could induce 
either of the men at Camp Lloyd to go out in such a sea?" And then suddenly the thought flashed into my mind, "It must be news from Hassell".

Throwing down my pack beside the trail, like a goat I raced down to the landing to find a group of Eskimo caribou hunters who had come up the fjord in an umiak that afternoon arriving shortly after I had left. Because of the high wind they had been obliged to hug the southern or windward shore of the fjord until up-wind from Camp Lloyd, when they had hoisted their sail and with a stern wind had swept over to our landing place. Close to the southern shore as they had been, their keen eyes had detected a faint column of smoke going up from a point near the shore. Since all the caribou hunters had already gone out to the coast, it was clear that this smoke must be made by one or more of the lost flyers.

On receiving this startling information Stewart and Etes had got out the powerful Mirakel binoculars, and had gone up to the radio shack for a better view. They were able to verify the position of the smoke column, which appeared white against the dark further shore at a point nearly six miles away across the fjord. A smudge fire was at once made at Camp Lloyd as an answering signal. The 
Eskimos were then questioned about the possibility of getting a small boat across. But they shook their heads dubiously. Etes and Stewart then decided to risk it. While the latter got together some food, Etes mixed the gasoline and motor oil, then with the aid of a half dozen of the Eskimos and after much difficulty, the Mullins steel boat was successfully launched.

When I, with my heart in my mouth, had arrived and joined the watching group of Eskimos, I glued my eyes upon the frail boat as it bobbed about among the seas. Had I been present when the umiak came in, I should not have permitted this attempt to be made, for the seas were sure to go down sometime after sunset. This the boys probably understood, and now we could only watch and pray that they might get safely across.

As soon as the situation was clear to me I had dispatched Marius with a note to Belknap at the observatory telling him of the prospect of saving the flyers, declaring the dinner cancelled, and asking him to come down as soon as convenient.

From near the tent-house there is a clear line of vision to the observatory and between them Belknap and Schneider now concerted that the former was to signal with his flashlight "Hassell Safe" if and when the rescue was effected after dark. 


\section{NORTH POLE OF THE WINDS}

After what seemed an interminable time our keen-eyed Eskimo visitors using my binoculars were able to make out that the boat had put in on the point of Nakajanga between the two forks of the fjord, and then, a little later that they had put out again and were making for the point where the smoke had been seen. The halt as we supposed, and afterwards confirmed, was to refuel the motor.

As we afterwards learned also, Etes ran the motor and Stewart held down the bow and scanned the shore for some sign of the missing flyers. In his account Stewart states that he could no longer see the smoke, but as they approached the shore where it had been seen a slow-moving figure was made out clothed in caribou skin, so that his first thought was, "It's only Eskimos after all". But now another figure appeared wearing a parka but without caribou skin, and there was a wild waving of arms and Etes suddenly yelled, "Fish!" and pointed the boat in toward the shore.

Etes and "Fish" Hassell were old friends and their meeting was a moving one. "Shorty" Cramer, wearing the long caribou coat in which Eielson had flown to the North Pole with Byrd and with a smile which seldom left his face, presented a striking appearance. The flyers were asked if they wanted any food. Hassell did not feel like eat- 
ing, but Cramer asked "Have you any fruit?" Yes, there was a can of peaches in the boat and this can he quickly disposed of.

In a few minutes the main outline of events in the flight and the subsequent wanderings were narrated, and Etes and Stewart were informed that the flyers had for more than two days discussed seriously making the flight again sometime the next year. 'They certainly were game.

Hassell explained that they had lighted a fire to serve two purposes-to rid themselves of mosquitoes, and to attract the attention of a sail which they thought they had seen. 'This must have been the umiak with sail hoisted. Their intention was to build a fire after nightfall and fire off the "Very" signaling pistol from this point on the shore, which it is interesting to note is exactly the one where our canoe and cache of provisions had been left for them but afterwards brought away. The flyers had heard the hum of the outboard motor of the Mullins boat when it was still some distance away, but they had had hallucinations-they then thought that the umiak under sail was one of these hallucinations-and so they had concluded that the hum was due mainly to the mosquitoes in their ears.

A half hour later Etes and Stewart began to 
consider how they should get back to Camp Lloyd. They waited for the wind to abate but without observing any noticeable change. Then they decided to try to make the point of Nakajanga. In attempting this they shipped a good deal of water before the point was reached, and with great difficulty they succeeded in getting all but Stewart ashore on the slippery rocks. As the boat was now in great danger of being dashed to pieces, Stewart managed to row it a half mile farther down the shore to a projecting point of rock, while the others made their way laboriously over the rocks along the shore. The boat was then pulled out and placed above the reach of the waves.

It was now getting dark and we at Camp Lloyd were increasingly anxious as we watched straining our eyes to make out the party, which we had seen to land on the point of Nakajanga. A lantern had been lighted and set up on a pole to serve as a guide when the boat should again set out. After a time we noticed two red signal shots and a little later the boat could be seen starting out again and we could follow its course in occasional flashlight signals. From these signals we could see that it was being constantly carried farther down the wind. Our Eskimo Nathaniel now came to me to ask if he and Belknap might not go out in the 


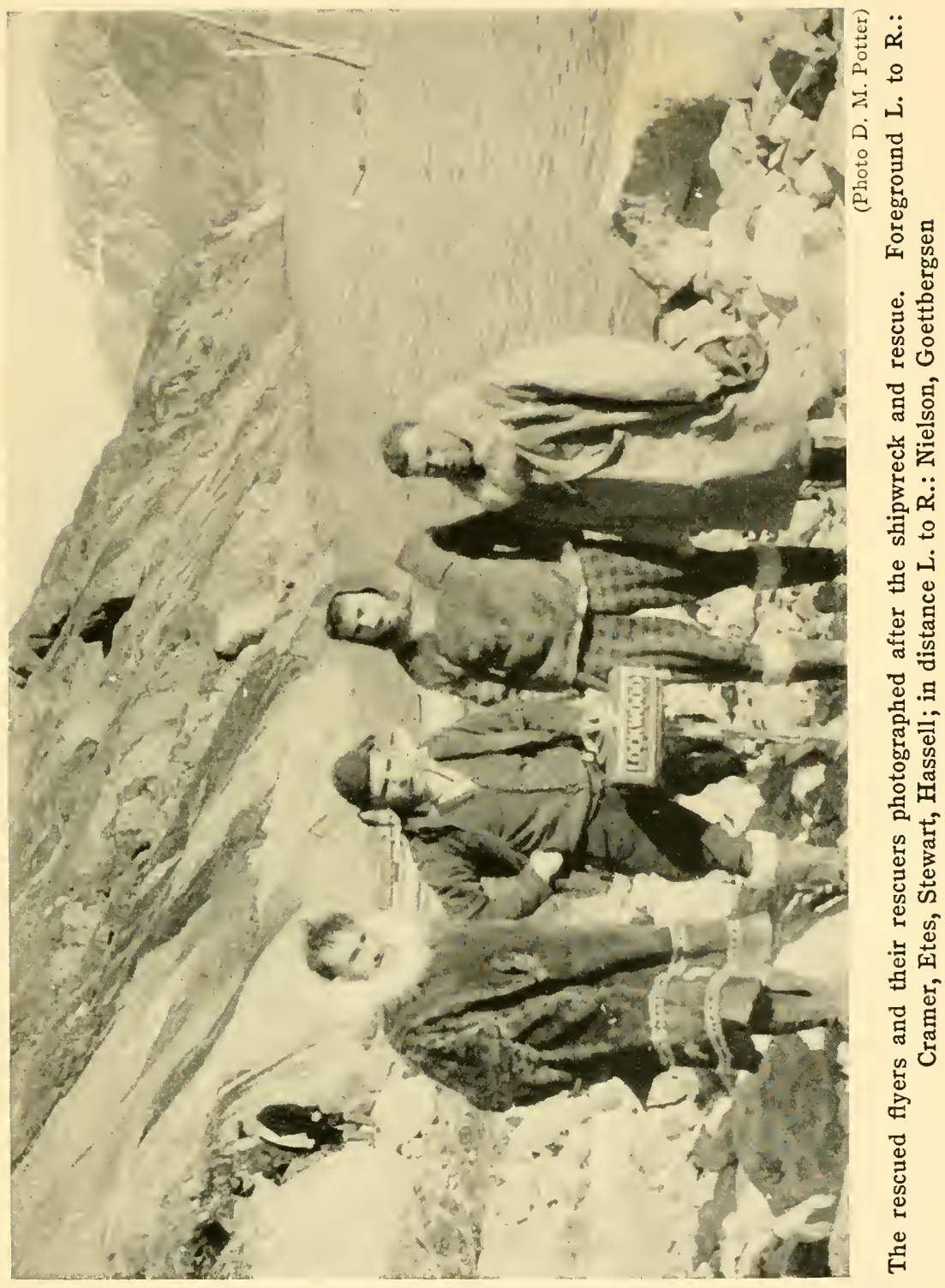


more seaworthy motor-dory so as to help in guiding the others in to our landing. Belknap agreed to this and as he was the most competent engineer and boatman in our party, I readily agreed. As they set out the dory being nearer our side of the shore and being likewise supplied with flashlight proved very useful as a guide to the others, and after much signaling we could see that the boats were coming together and later could hear both the motors and note that they were coming nearer to the landing. Our tension now greatly increased. At last both boats, now in quieter waters, were racing in to Camp Lloyd with a following wind andyes, now we could make out four men in the Mullins boat and we knew at last that Hassell and Cramer had been saved and our own party also from a perilous situation.

It was a great moment when we waded into the water and helped the men ashore. Hardly had we exchanged a word before Hassell tore off his flying helmet and handed me letters from my family, letters which had come by the first air transport between America and Greenland. $\mathrm{He}$ then told me that the greatest "kick" they had had on the entire flight was their rescue on the fjord in the little Mullins boat.

Both Hassell and his navigator Cramer, were 
very lame and sore, and it was only very slowly that we made our way over the hundred yards of trail to the tent-house, where for the last half hour or more I had been keeping a big pot of vegetable soup ready for them. On the table nearby lay a pile of caribou steaks ready to put in the frying pan, provided the rescued men should be in a condition to attack anything so hearty. They very wisely kept to the soup and even then for a fortnight Cramer suffered from the effects of their starvation of the past fortnight.

But we must not forget that the world is waiting for news of Hassell. The instant the boats were ashore, which occurred at nine fifteen in the evening when it was already very dark, Belknap had flashed the signal, "Hassell Safe". Schneider watching outside the observatory, caught the signal and rushed in to report to Baer sitting at the radio transmitter. In dot and dash code Baer sent out the call, "2 UO, urgent, $2 \mathrm{UO}$, urgent". Dick Hilferty sitting at his instrument in the New York Times annex heard this call of his station and in two minutes from the moment that Hassell had set foot on our shore, the New York Times Radio Department was "standing by" waiting for the rescue story.

The outlines of this thrilling story I was at this 276 
moment digging out of Hassell between his mouthfuls of soup, and a quarter of an hour later with lantern in hand I was hurrying up over the rocky trail of three miles to the observatory, which I reached in about three quarters of an hour. I seated myself and wrote out the initial sentence, "Hassell and Cramer here safe and well." As I continued to write Schneider carried the first sentence over to Baer, who shot it in to the Times office. No sooner were these words received by the Times than there was an interruption, "Hold on, I must see the editor". One could sense the thrill within the Times office. While the editor was getting this first news another operator took up the transmitter and sent Baer the message, "Cramer's brother Will is here in the office trying to organize an expedition by planes to hunt for the lost flyers". But now the operator is back from the editor's office and the next sentence goes out, "Notify families at once. Outline story follows"; and again an interruption, "Hold on, I must see the editor again!" Again the assistant is at the Times transmitter with the remark, "Bill Cramer is now passing around the cigars".

Meanwhile with as clear a head as I can command, I continue my writing, and every few sentences Schneider takes my sheet over to Baer and 
I go ahead with a fresh sheet of paper. And so by this process within two and a quarter hours from the time Hassell landed at Camp Lloyd, the outlines of his story were in the New York Times office, and were being sent by wire all over the world so as to appear on the front page of the papers the next morning.

The outlines of Hassell's story were filled in by Hassell himself the next evening after he and Cramer had painfully and slowly made the climb to the observatory. The first night they had slept at Camp Lloyd. Both were very tired and had been half starved during their fourteen days of wandering in the wilderness, first of ice and then of mountain cliff, deep-walled lake, rushing river, and treacherous quicksand. They had lived on a ration of five ounces of pemmican daily, and one or two ptarmigan which they had shot with the Mannlicher rifle which Cramer carried. They had with them no bedding, but had lain down in their parkas under shelving rocks throughout the nights, huddling together for warmth.

They now told us of their flight since leaving Cochrane. They had arrived safely at Port Burwell near Cape Chidley in Labrador as planned, but had made the trip slowly so as not to arrive at Camp Lloyd before daylight. As they looked out 
over Davis Strait they saw clouds running up to 10,000 or 12,000 feet. Before passing into the clouds Cramer, the navigator, had dropped a flare, and finding the wind light from the southeast, he had made a correction to the course, which was set for the Knud Rasmussen ice-arm, of two degrees to the right. They learned later that in the clouds the wind was blowing a small gale from the opposite quarter and this had carried them during the crossing nearly two hundred miles off their course and down the shore to the southward.

On reaching the Greenland coast they at once came out of the clouds, and seeing an ice-arm off to the right they supposed it to be the Knud Rasmussen ice-arm toward which they had set their course. They then began searching for the fjordmouth while circling over Fiskenaesset on Sunday morning at church time. They soon found what seemed to them to be the fjord-mouth, for fjords are nearly everywhere on the Greenland southwest coast, but on ascending this fjord they found it not 120 miles long, but only twenty miles. This showed them clearly their error and now from the map they were able to identify the ice-arm which was in view as the Frederikshaab Isblink in far southern Greenland.

They had now found their position, but they 
were already low on fuel, so instead of returning to the coast and following the shore northward they decided to fly along the ice margin direct toward Camp Lloyd.

As they passed in rapid succession over ice tongues, deep-walled valleys, and high rock ridges athwart their course, the air was so "bumpy" that they could hardly keep their seats in the plane. At one place the plane dropped suddenly about 1000 feet. Coming then over the broad inner portion of the Knud Rasmussen ice-arm, they found, as had been promised them, that a southwest wind was blowing down the slope and at this time it proved to have a force of about sixty miles per hour. This carried them rapidly on their course flying at an altitude of 5500 feet and only about 300 feet above the ice. Favorable as this wind was for them, it could not fully make up for all the gasoline spent on the wide detour, and so with only five gallons of gasoline remaining when they had got over the ice-arm and were about 75 miles from the landing field prepared for them, they decided to try to come down on the ice-cap. It is disheartening to recall that had they known all the conditions they could probably have reached our landing field with the fuel supply still remaining in the tank. We were waiting for them on the 
field, which was clearly marked, and there is little doubt that they would have made it successfully.

I had not believed that they could come down safely on the ice-cap unless they were to go in at least fifty miles, but apparently to their surprise as well as mine, they came down at a point probably not more than ten miles inland and in about a foot of slush ice between ridges. They carefully covered up the engine, locked the car, and taking only a small lump of pemmican they started out for our camp. They had become somewhat confused, it would appear, in thinking that the lake known as Taserssiak close to the ice-arm itself was really the Söndre Strömfjord, or they would not have started out with so little preparation. They carried, however, the rifle and a hatchet and, of course, the map. It was just fourteen days that they wandered, first jumping wide ice crevasses of the inland-ice, finding their way out to the margin after several futile efforts, then fording streams by day, caught in quicksand, and huddled together for the night, footsore and weary, halfstarved, but game to the end and with smiles on their faces, they finally reached the point from which they were rescued by Etes and Stewart.

Shortly after getting down from the ice-cap they had come upon a caribou that was apparently 


\section{NORTH POLE OF THE WINDS}

less sophisticated than this animal usually is in southwest Greenland. The caribou was near and apparently unfrightened. I asked Cramer why he did not shoot it, to which his reply was, "We had no wood to cook the meat". Later on they shot a few ptarmigan, but they lived practically throughout on a five-ounce ration daily cut from the lump of bison pemmican which they had brought with them from the plane.

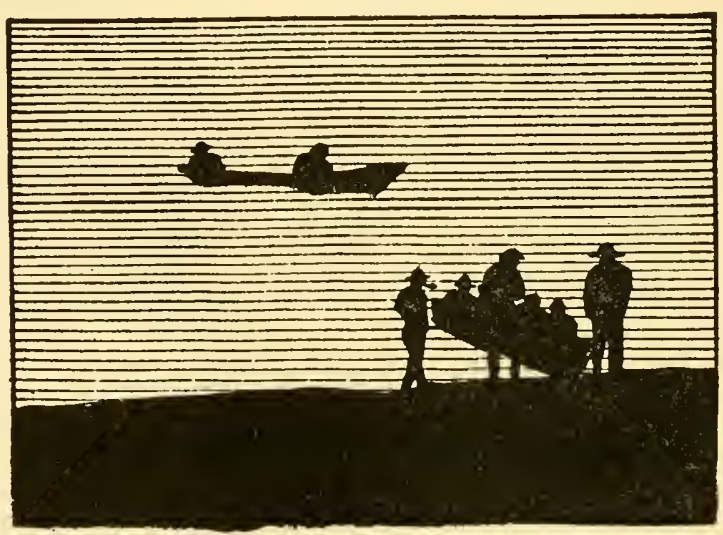




\section{CHAP'TER XXIII}

\section{SHIPWRECKED}

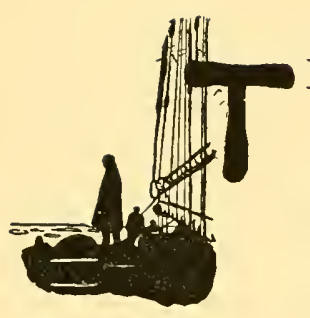

HE events leading up to the rescue of the flyers would incline us to ascribe something to Providence. The fortuitous arrival of the Eskimos in their umiak, the high wind that made them hug the south shore of the fjord, the arrival of the wanderers opposite Camp Lloyd when they did-rather than two days later when the summer party would have already left for the seasoneach of these was a factor which if absent might have led to a different result. As it was, their rescue was effected only two days before we of the summer party went out to the coast to sail homeward.

Though both men had been game to the limit, the reaction showed what they had been through. They were content to rest without effort. They had 
little interest to be taken even to the landing field which we had so carefully made ready for them. This is, of course, in part explained by the fact that with the best arrangements we could make, they would have between two and three miles to walk over a rough trail, and Cramer's feet were covered with blisters, while both men with great difficulty made the climb to Mount Evans. Moreover, they were convinced that when the attempt was repeated to fly across Greenland to Europe it must be with an amphibian plane which would permit of landing while en route to Greenland, and especially on the Labrador coast before passing out into the cloudy region of Davis Strait.

The search for Hassell and Cramer which the Danish Government had been generously conducting now for nearly a fortnight, had made it extremely difficult for us to charter a motor sloop to get ourselves to Holstensborg. These boats were either still engaged in the search, back again in the halibut fishing, or on special duties necessary to make up for so much time that had been lost. Nearly every coast colony had used up its supply of motor fuel, and it was necessary for me to provide a supply of kerosene for fuel on the return journey of the sloop, which fortunately we were able to do. At last Governor Bistrup at 


\section{SHIPWRECKED}

Holstensborg was able to secure for us the little motor-sloop Nakuak which in July we had chartered to get in to our base and relieve Carlson.

The Nakuak arrived at our anchorage in the very early morning of the fourth in charge of its Eskimo skipper, who with his crew were part owners of the vessel. I was awakened at four thirty in the morning by shots fired by our Eskimos and, rousing, found the new skipper and crew already ashore. The Nakuak which lay at the anchorage was the usual type of halibut sloop with auxiliary motor accustomed to burn "distillate". It brought supplies which we had ordered for the winter and was to carry out some of our material for shipment home.

I soon had breakfast started after sending a note to the observatory to get everybody up, for we were to have a very busy day, all hands unloading the boat and loading cargo, and it is possible to use the landing only when the tide is at flood.

Carlson and Marius expressed a willingness to undertake an expedition to find the "Greater Rockford" and bring away at least the navigating instruments and carry the propeller blades out to be cached at the edge of the ice, from which they could be brought away by dog-sled at some time during the following winter. Cramer described the 


\section{NORTH POLE OF THE WINDS}

place and the route followed as well as he could, and they planned to leave the next morning expecting to be gone about three weeks. But the next morning Marius was down with grippe, doubtless from germs brought in from the coast by the Eskimo crew, and so the trip had to be given up for the present.

We were anxious to get away on the tide in order to leave before nightfall and with some difficulty we were able to do so. Enok and Peter, two of our Eskimo helpers who have been unable to do packing for some time, go back with us. Marius and Nathaniel remain behind to pack the winter supply of coal which has just come in on the Nakuak. They will go out when the other winter supplies arrive from the Disko.

The tiny cabin of the Nakuak in which we cooked and ate our meals has benches on either side of a central folding table, and on these narrow benches Cramer, Belknap and I managed to wedge in our sleeping bags. Hassell and Etes stretched theirs out on the cargo in the hold, while Potter and Stewart found places for themselves on the deck. Our Eskimos joined their friends of the crew in the tiny forecastle where they curled up together like dogs and slept comfortably.

The skipper is in control of the ship and we 


\section{SHIPIVRECKED}

therefore retire early to make up for sleep lost during the last few days. The fjord has a nearly uniform width of between two and three miles throughout its entire length of 120 miles, and it is so deep that an ocean liner might navigate it without difficulty. The Gertrude Rask, motor-ship of the Greenland Government, sailed up the fjord to its head in 1924. If it is to be safely navigated, however, it is necessary for the man who is at the helm to keep awake and not run the ship into the precipitous rocky walls or on the reefs just off shore. Toward dawn of the fifth our skipper was himself at the helm and, as he frankly confessed to us, he fell asleep, possibly due to the specially prolonged activities in connection with the Hassell search along the coast.

I was awakened by the shock as the Nakuak struck, and a moment later slid over the reef and again gathered headway. As I rushed up the little ladder to the deck I shouted to Cramer, "I'm afraid we're wrecked". From the deck I could make out the black wall of rock about one hundred feet off towering above us, and dimly also the distant opposite wall. A dark head was poked out of the wheel-house and was silhouetted against the lesser darkness. Almost immediately simultaneous cries came from the cabin and the hold that the ship 


\section{NORTH POLE OF THE WINDS}

was filling. Water must have been entering the engine room, for the skipper now turned the helm and drove the sloop straight for the shore. I dove back into the cabin, fished my boots out of about a foot of water, and we all now began passing bedding and more valuable equipment that was at hand up onto the deck. Steam was now issuing in great volumes from the engine room and the ship now struck a second time and this time remained fast on the ledge between two rocks. In the thick darkness we continued to pile our stuff on deck while the dinghy was being loaded for the shore. We had the dinghy already ashore with one load and Etes had gained a foothold on the narrow ledge of rock to unload her, but now the ship appeared to be settling by the stern. Fearing she would slide off into deep water I now halted the salvaging operations and had both anchors dropped into the dinghy and taken ashore. The men succeeded in getting a foothold on the slippery rocks and wedging the flukes of the anchors into a crack. Our Eskimos then worked at the windlass until both anchor chains were taut. We could now with something more of deliberation see to getting our stuff on shore, where it was scattered about on flat ledges just above the water. Already the dawn was coming and we were able to work 

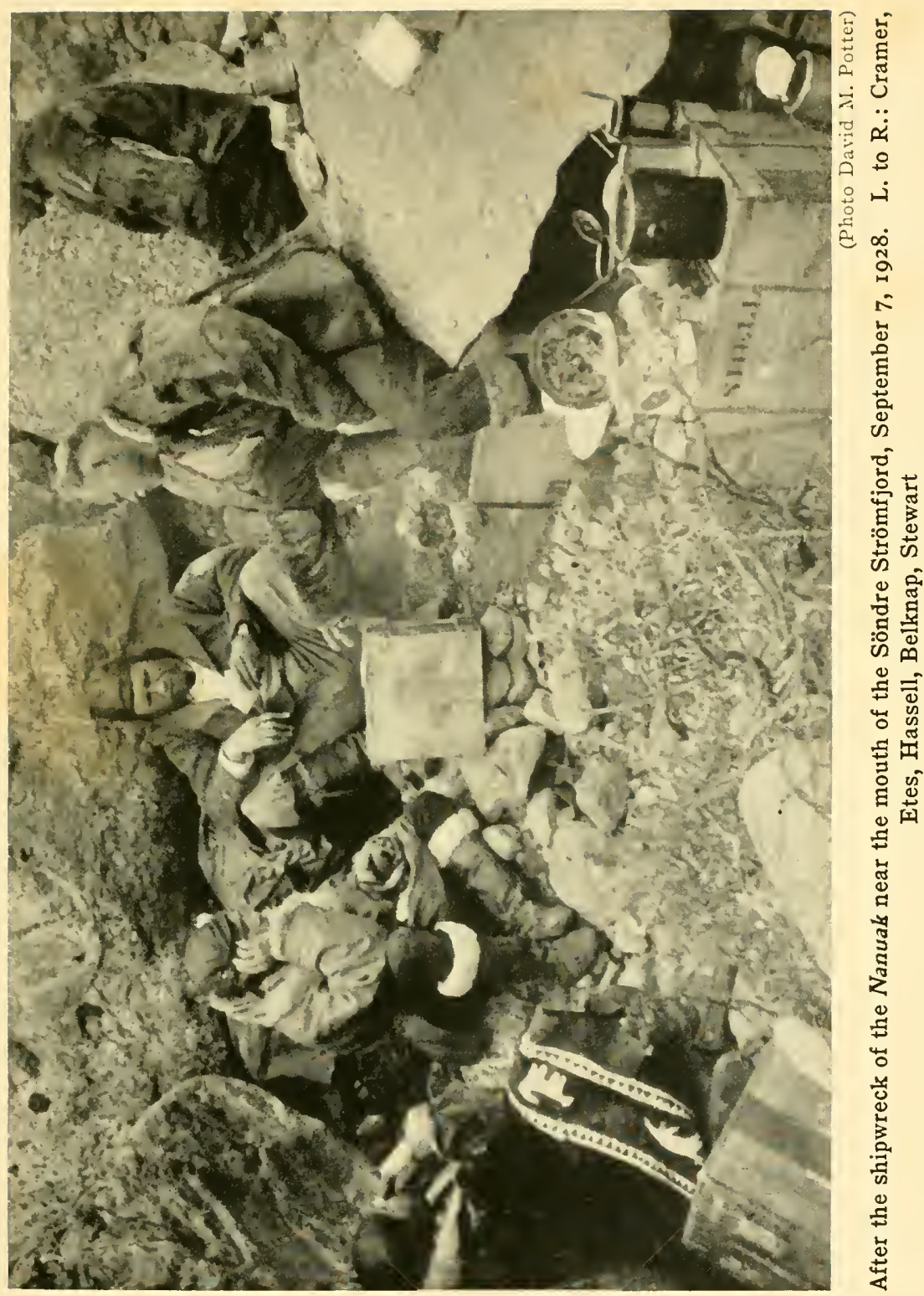



\section{SHIPWRECKED}

more effectively, carrying up our things to a better place above high tide.

Everything that had not been taken out and placed on the deck was now under water in the sloop and the tide was fast rising, for we had struck at extreme low tide. We had however, worked like beavers and it was in the gray of the dawn that we had most of our personal belongings on shore though badly soaked in salt water. We could now crouch around a primus stove and have an early breakfast of erbswurst and sausages. As we huddled about our cooking pot feeling the cheer that comes from hot soup on a raw morning, Hassell generously remarked that I had had good luck with the expeditions until he joined; and as if to drive home the point Cramer added that this was the fifth wreck since they had started the flight project. There was, first, a crack-up while they were trying out the plane in Iowa; a second crack-up occurred at Clarion, Pennsylvania; then there was, third, the crash at the first take-off in Rockford; fourth, the disaster to the plane on the inland-ice; and now, fifth, our shipwreck. Thus catalogued the recital was quite impressive.

As it was now getting lighter I climbed up to a lookout point from which I could make out the wedge-shaped island mountain which like a stop- 
per to a bottle partly closes the entrance to the great Söndre Stromfjord and is known as the Simiutak (Eskimo for "stopper"). This mountain and the glaciers which appeared on the other side of the fjord showed clearly that we were about twenty miles up the fjord from the mouth.

We might have been in much worse plight. We had with us tents and sleeping bags, cooking utensils and a fair quantity of food. There was a brook less than two hundred feet away, and there were probably fish in the fjord, and perhaps hares up over the cliff on the plateau. About 50 miles down the coast was, we knew, a little Eskimo fishing settlement called Kangamiut, and there was pretty sure to be a Danish official and a motor-sloop there.

Along the coast were skerries or rocky islets which act as breakwaters to keep off the seas, and the skipper with one of the crew now volunteered to go in the twelve-foot dinghy carrying a note from me to the Danish manager. I therefore prepared a note describing our situation and offering compensation to come in and take us out. As the wind was high and high waves were rolling in we felt somewhat concerned lest our boat party might not win through to the settlement. The sun, however, now came out and we spread our wet clothing on the rocks to dry. 


\section{SHIPWRECKED}

There was also a chance of rescue from another quarter. The umiak, which had visited our camp and brought us the information of the smoke column sent up by Hassell, was now making its way down the fjord on the way to Sukkertoppen. These umiak parties are accustomed to lay up at night on the shore and our Eskimos were sure that this one was somewhere on the fjord above us, and it seemed likely that they would soon be passing our position. For a suitable recompense they would doubtless be willing to leave their heavy loads of caribou meat and take us out to Kangamiut and then later come back for the meat cargo.

At one-thirty in the afternoon the tide was on the ebb and the wind seemed to have moderated a little, so our two Eskimos set off in the little dinghy. Potter, who is our best alpinist, now started up the cliff to get an outlook and see if he could make out the position of the umiak party. A few hundred yards up the rock in the down-fjord direction $I$ was able to find an excellent bit of level ground where we could set up our tents in a position from which one could look down the fjord in the direction from which relief should come to us. With the sun now bright we realized what a scenic position we had fallen into for our forced detention. Across the fjord glaciers descended 
from the plateau nearly five thousand feet high, and these vast proportions so overpower the lower and nearer objects that it is hard for us to believe that the further shore is nearly two miles away.

Potter returns in the late afternoon having reached the summit of a peak 3200 feet high as measured by his aneroid. From this peak he could with a glass make out the Eskimo camp not far above us on the shore but extremely difficult for us to reach because of the steep cliff and the rock slides between. As he made his report it was already getting dark and we could not attempt to reach the Eskimo camp that day. Lest, however, they should make use of the ebb tide and get past us during the night Peter was commissioned to sit up and watch. The next morning Potter accomplished the difficult and dangerous feat of making his way over the cliff and slides to the Eskimo camp, but alas, only to find it deserted. The Eskimos had evidently slipped away in the night with the outgoing tide which came at the darkest hour. Peter had not seen them. I now blamed myself that I had not taken greater precaution, but I had had great faith in Peter's capacity.

With this chance of getting away removed and with nothing yet heard from Kangamiut, we begin now to fear that we may be marooned on this cliff 


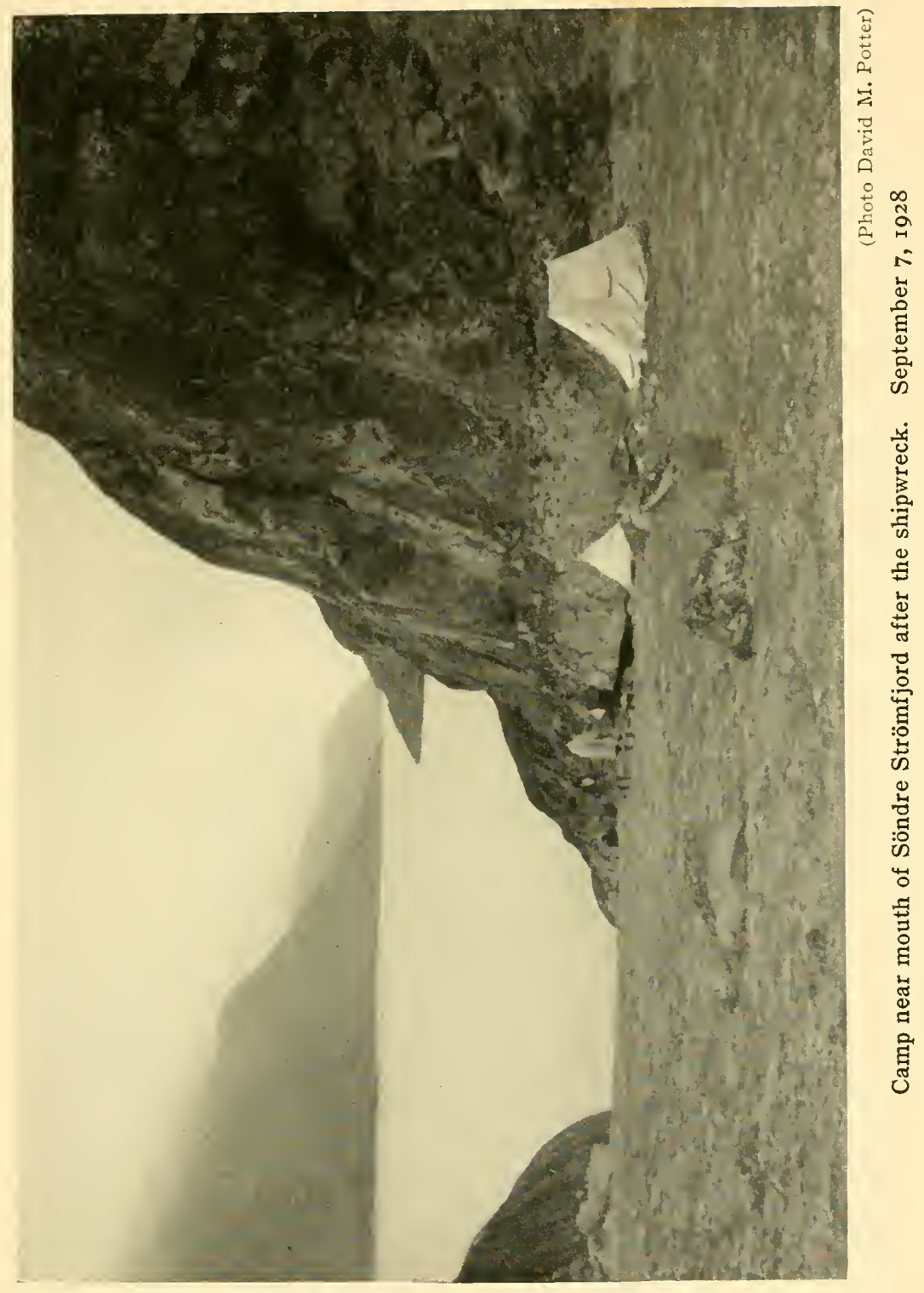





\section{SHIPWRECKED}

for a considerable time. I therefore consider strictly rationing the party to begin the next day if no vessel makes its appearance. Watch parties at intervals climb the little cliff between our camp and the fjord to watch the fjord below.

We now go over our supplies very carefully. A pemmican box which he had thought contained our collection of rock specimens made by Stewart, proved now to be full of pemmican, about 36 pounds in all. This means then that our specimens are somewhere down in the hold of the Nakuak under water where we cannot reach them. We have also another box with 26 pounds of pemmican, also some erbswurst and a little canned fruit. But as this is for five white men and four Eskimos it will not last very long.

On his climb up the cliff Potter had seen Arctic hares and so Nathaniel is sent out to hunt with a rifle. Stewart unlimbers his fishing rod and starts out to a little bay to fish. Etes and Potter set about constructing a raft so as to continue salvaging from the wreck. For this purpose they employ the empty gasoline cans of which we had many on board.

If our Eskimos had won through to Kangamiut, we should, we believed have been taken off the next day. We feared, now, that they had not got through 


\section{NORTH POLE OF THE WINDS}

or else that the manager was away; for even if my note could not be read, the Eskimo skipper would be able to give the necessary information. Peter now comes to me and volunteers to try to go to Sakardlit for help going over the plateau. This is a very hazardous undertaking and I do not favor it, at least as yet. Peter evidently is feeling troubled over his failure to see the umiak as it passed in the night. $\mathrm{He}$ is a very faithful Eskimo and I do not believe it was due to any fault on his part. I am inclined to think that our better chance of early rescue is to send a party down toward the mouth of the fjord from which a possible passing sloop could perhaps be signaled.

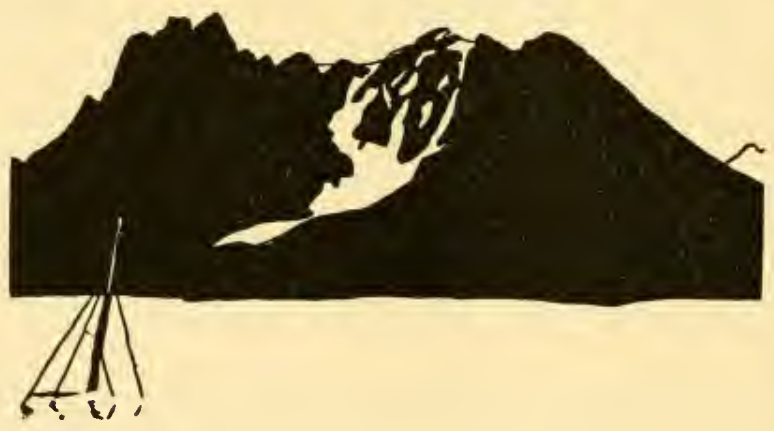




\section{CHAPTER XXIV}

IN PERIL OF WATERS OFF THE GREENLAND COAST

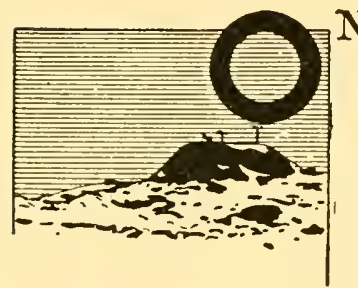

$\mathbf{N}$ the afternoon of the 8th at about 1 o'clock after Nathaniel had set off to hunt and Stewart to fish, the remainder of the party lay sprawled on the ground near the tents listening to the inimitable yarns of Hassell and Cramer drawn from long and picturesque flying experiences. It was now the third day since the wreck, and if the dinghy had got through to Kangamiut we should have been taken off at least a day earlier. A watch down the fjord was being maintained. I was busy in my tent with my notes and I left it to say to the others that I believed now we must begin at once to strictly ration the party.

On my way to the group sprawled on the ground I caught a view down the fjord, and was overjoyed to see a motor-boat coming up. It was a 299 
small sloop similar to the wrecked Nakuak and it must be the long awaited relief vessel. I sang out lustily, "Motor-boat coming". Everyone seemed stunned. It was sometime before the reaction came. I now called out, "Down tents and everybody to the landing", and had begun rolling my bed-roll before the good news seemed to have sunk in. Gathering up the bed I hurried down to the place where we had landed from the wreck, calling out to the Eskimos as I passed their tent and using the necessary pantomime. Peter seemed not to believe me and asked, I thought, if I had seen the boat myself.

Hardly had I reached the shore before the motor-sloop rounded the point and was already letting go the anchor. The dinghy at once came into shore bringing Fiskemeester Nielson of Sukkertoppen, with whom I was already acquainted, the Sukkertoppen schoolmaster Helge Nyström, and the Bestyrer Alexander Goettbergsen, manager at Kangamiut. The sloop was the Nipisak from Kangamiut. Before the good Goettbergsen had come to our rescue he had felt it his duty to get authority from his superior, Bestyrer Essermann at Sukkertoppen, and having no telegraph or radio, he had first made the long journey of sixty miles in the Nipisak. This of course ac- 


\section{IN PERIL OF WATERS}

counted for the presence of Nielsen, who was in charge, and of the schoolmaster who had been permitted to utilize the opportunity for a little outing.

Our joy at seeing these good people hardly needs to be expressed. A generous supply of provisions and an even more generous supply of beer and schnapps was brought ashore in the boat, and as Stewart was already cooking supper from our supplies, we had much good cheer as we made our preparations to get off with as little delay as possible.

Since our Eskimos were bound for Holstensborg, they remained on shore and I engaged a husky Eskimo from the Nipisak who fortunately had his kayak with him, to go in it to Holstensborg with a note to Governor Bistrup which would bring a boat to take off the Eskimos and undertake the salvaging of the Nakuak. This we afterward learned was successfully accomplished. We got away at about $2: 30$ in the afternoon and had reached Kangamiut without incident just as night was closing in.

Kangamiut was the original site of Sukkertoppen, and is now known also as Gamle (old) Sukkertoppen, a Danish word which means sugarloaf, from a high rounded knob of rock close to the little settlement which is one of the most striking 
landmarks on the entire Greenland coast. The Eskimo population of Kangamiut was ranged along the rocky landing place to receive us. The jovial and hospitable Goettbergsen insisted that we should all be his guests in his cheerful home, and so about ten o'clock in the evening we all sat down to a real banquet of many courses, including halibut just in from the banks, luscious steaks of caribou and all the "fixings" to be found nearer home. It was eleven o'clock when we had finished, and as we were to be off for Sukkertoppen at dawn the next morning we asked to be allowed to get at once to bed.

At four the next morning it was raining so we were not called until five. The voyage was made in rain, and at Sukkertoppen we were warmly welcomed by Bestyrer and Mrs. Essermann and we sat down to tea in their pleasant home. The news of the rescue of the flyers at Camp Lloyd had reached Sukkertoppen and everyone was keen to see the men who had gone through such thrilling experiences.

When the Nipisak had first arrived at Sukkertoppen with the news of our shipwreck, Bestyrer Essermann had dispatched one of his little vessels to Godthaab, the capital, one hundred and twenty miles to the southward so as to notify the Lands- 


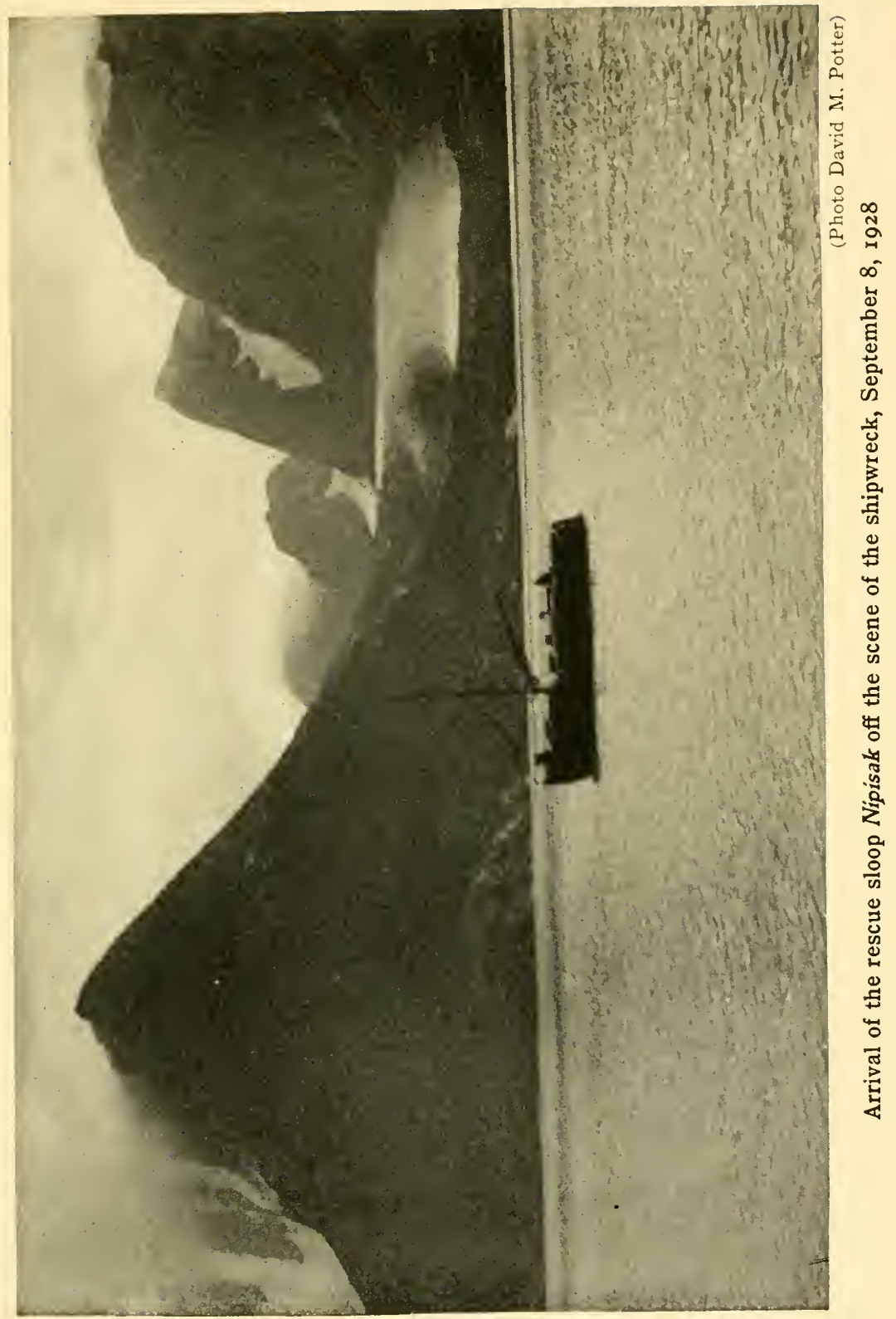



vogel. Inasmuch as the Disko on her northward journey had probably already reached Godtliaab, and in any case would soon do so, I was somewhat disquieted by this information, lest this news of our shipwreck should be sent out to the world over the Disko's radio without the later news of our rescue. I was therefore much pleased when the manager permitted us to have the Nipisale but with a different Eskimo skipper and crew who were familiar with the coast between Sukkertoppen and Godthaab.

After Fiskemeester Nielsen had also in turn hospitably received us in his home we set sail for Godthaab. With Potter I still planned to proceed to North Greenland on the Disko, and as the shipwreck had prevented our embarking at Holstensborg, we must now reach Godthaab before she sailed from there.

Little did we then realize the thrilling experience which lay before us, one far more trying to go through than that of the shipwreck near the mouth of the Strömf jord. At the little settlement of Napasok, which is about forty miles from Sukkertoppen, we tied up for the night but slept on board. At dawn the next morning I was up and awakened the skipper so that he might proceed with the first light of day. 
Our troubles now began with a temperamental motor, which at frequent intervals refused to function; and after taking an outside passage in a heavy sea, we crept behind some reefs and there anchored. Here our very competent native skipper took the motor apart and repaired the trouble. It was, however, late in the afternoon when we were again ready to proceed. Before starting out he came to me and by elaborate pantomime indicated that he would go outside, but would return behind one of the rocky islands with which the coast was strewn in thousands and that there we would sleep for the night. To illustrate this he leaned his head on his hand, and closed his eyes as though sleeping. I consented.

We weighed anchor and put out in the open sea, but were unable to get back again. The winds rose and the seas were very heavy. It soon became evident that the skipper had lost faith in his compass, which was likely enough well founded since it was kept in the engine room. I now noticed with alarm that he was steering by chart and compass. After dark we saw him put the compass forward on the roof of the cabin and between the port and starboard anchor chains. At intervals he would come forward, illuminate the compass by flashlight, and go back to the engine 


\section{IN PERIL OF WATERS}

room. On the whole it did not seem best to interfere, though we fully realized that we were in a very precarious situation. Throughout the long

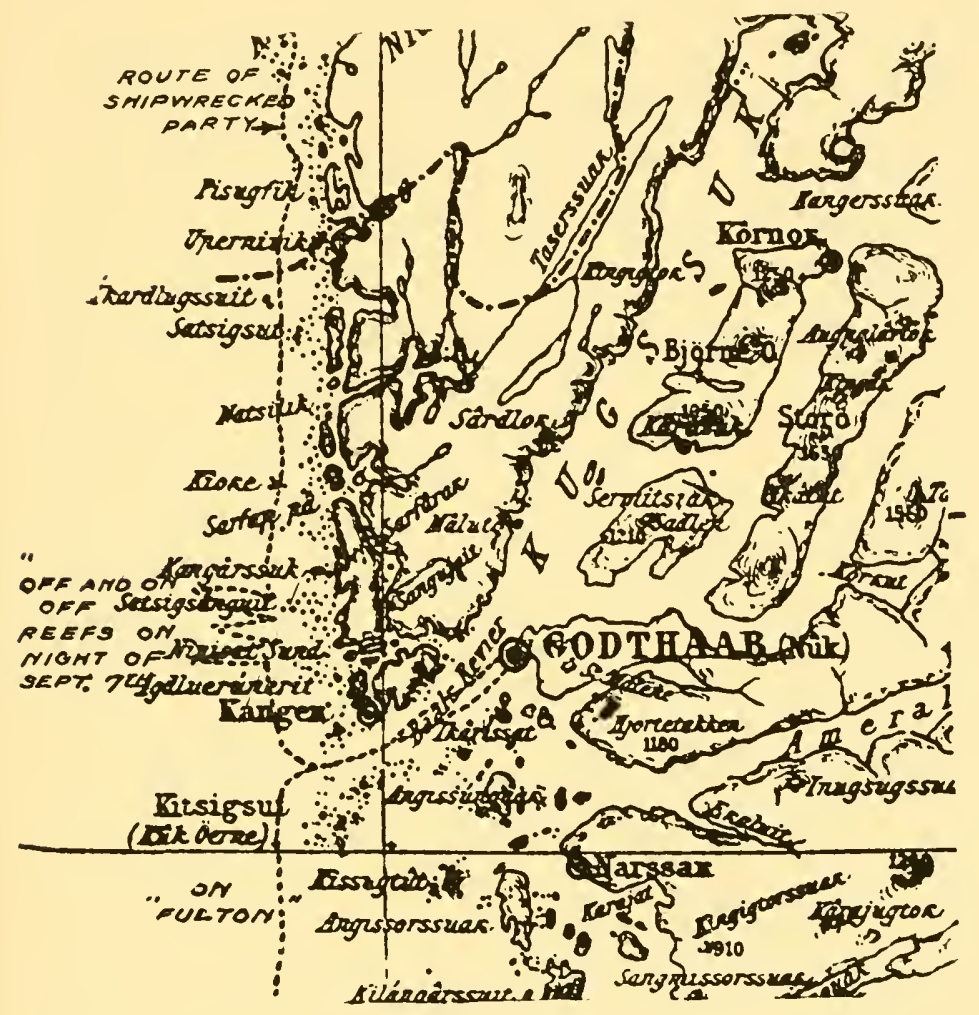

dark night the Nipisak thrashed about in a heavy sea sailing "off and on",-sailing out to sea, turning and sailing a course toward the reefs, and then just off the line of white water again turning out to sea. These outer reefs were some eight to ten 
miles from the coast. Had our motor ceased to function, as it had done during the day, we could not have escaped destruction, but the skipper's tinkering of his engine had fortunately been well done, and we never for an instant lost steerageway. With what anxiety we waited for the dawn! Cramer was still suffering from digestive trouble brought on by his late starving experience and was in addition very sea-sick. He was in the cabin with me and was most uncomfortable.

There seemed nothing that we could do but wait and trust to our skipper's skill in avoiding the reefs. Potter, always alert, spent the long night with the skipper in the engine room. Just as dawn was breaking the sloop passed over a reef so that the white water showed clearly beneath us, but fortunately a heavy sea carried us over without striking. Had we struck nothing could have saved us, since we were from eight to ten miles off the coast in a very heavy sea.

Soon now it was light enough to see and we could make out distinctly the lofty Hjortetakken and the "Saddle", the two snow-capped peaks which betrayed clearly the position of Godthaab. We were now able to thread our way through the reefs by the channel which enters the fjord. It had been for us a 200 mile voyage, though only about 


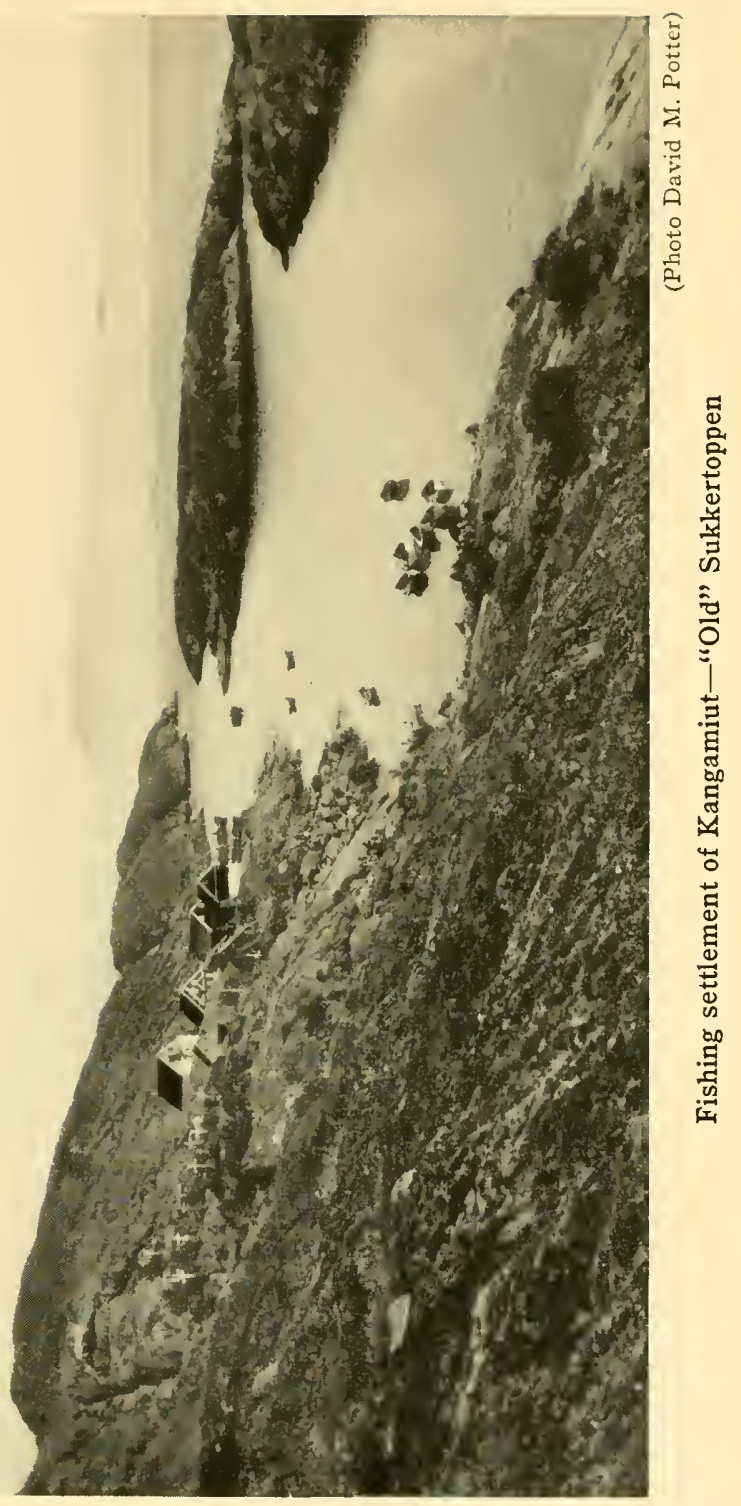





\section{IN PERIL OF WATERS}

120 miles by direct route. Once more our luck had been with us and we found the Disko in harbor scheduled to sail in three hours. On board her was the genial Director for Greenland, the Honorable Jens Daugaard Jensen and also the Landsvogel Peterssen.

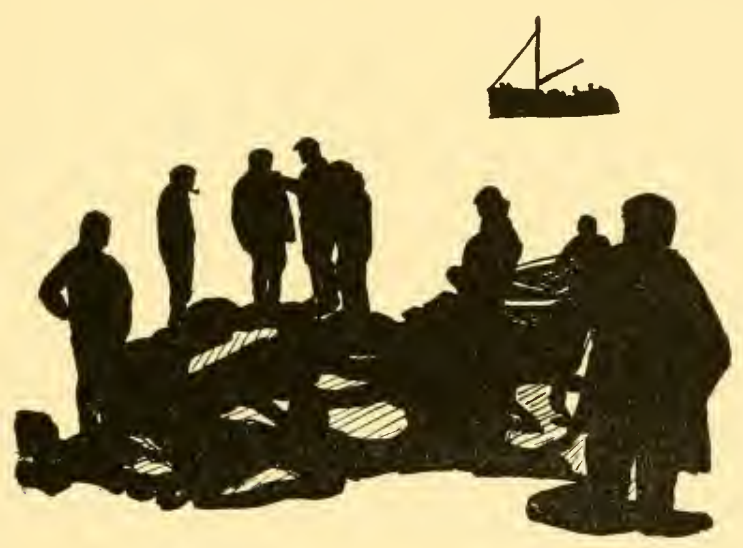




\section{CHAPTER XXV}

ABOARD THE TRAMP-SHIP FULTON

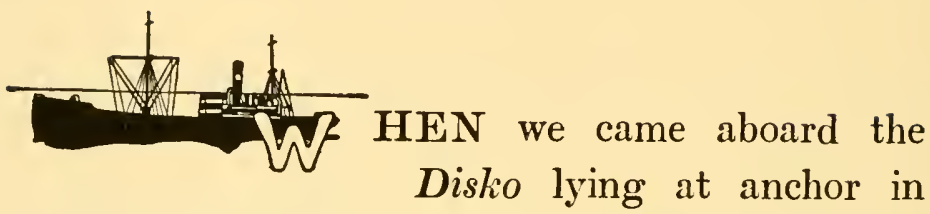

Godthaab Harbor, I was pleased to learn that no account of our shipwreck had yet gone out over the Disko radio, so a hurried note was sent to the New York Times with a brief account of the shipwreck and rescue. Here at Godthaab in the few hours which remained before the Disko was scheduled to sail, it would be necessary to arrange for the transportation of five members of the Expedition to the mining settlement of Ivigtut in extreme southern Greenland, so that they might sail to Philadelphia on the ore-freighter Wagland which was to depart at some uncertain date late in September.

Preliminary requests by radio sent from Mount 312 
Evans first with the Ivigtut authorities and later with the Landsvogel at Godthaab, had indicated that it would be very difficult, even if it should be possible, to make a contract for motor-boats upon such a voyage. This would be difficult at any time, and was doubly so now for the reason that the boats had been in use searching for Hassell and could now no longer be spared. A further difficulty was that motor fuel had been largely used up. The attempt to get passage on a freighter, the Fulton, which had recently been in Holstensborg Harbor, had been frustrated by the slow radio exchanges between Mount Evans and Godthaab. Moreover, since our experiences of the past week, we were not especially keen to undertake further voyages on small boats, and this one of more than two hundred miles to be made with Eskimo skippers and on a coast none too well known to them.

The Disko, we found, was sailing in three hours to North Greenland with all her passenger quarters taken and every inch of cargo space filled. Furthermore, it would be more than a month before the vessel could reach Copenhagen. A pleasant surprise was now in store for us. In the harbor at Godthaab we found at anchor the trampship Fulton of 800 tons making preparations to 
depart for Ivigtut. Her skipper, Captain Almsted, on learning of our difficulties generously offered to take us as his guests, not alone to Ivigtut but to Copenhagen as well, provided we could find the means to feed and sleep ourselves. This would permit us all to get back to the United States at least a fortnight earlier than we could by any other method.

There were, to be sure, no cabins on the boat, but there was a very comfortable little saloon with a coal stove and a dining table. The necessary dishes and a portion of the food supplies I was fortunately able to purchase from the Bestyrer at Godthaab, and I believed it would be possible to find the rest once we had arrived at Ivigtut. I therefore accepted with alacrity and most gratefully the offer of the captain. With some reluctance I decided to give up my trip to North Greenland, as it was to delay more than was desirable my return to the University. There was, on the $\boldsymbol{F}$ ulton, as we soon found, an excellent cook, so that the food problem was rather easily arranged. At night the sleeping bags of the party were spread out on the floor of the saloon, though as the captain had a bunk in the chart room, he insisted that I should spread my sleeping bag in his bunk just off the saloon. To Captain Almsted, 
and to his jovial first officer, Captain Ibsen, we owe a happy solution of our serious problem.

Since Potter was to spend the following year in Europe, and wished especially to visit North Greenland now that the opportunity offered, a place for him was with some difficulty secured on the Disko for the northern cruise. This would make it possible for him in my place to attend to some matters which had been planned with Governor Bistrup for the winter staff at Mount Evans.

On reaching the Disko our party must have presented a particularly unprepossessing appearance. Hassell and Cramer had only the clothes in which they had made their wanderings, and we had all slept in our rough clothing for days since leaving Camp Lloyd. As we came up in our little dinghy, the Disko had its decks covered with welldressed passengers including a large number of ladies who seemed to be on a luxurious excursion trip. Our party made a general rush for the bathroom of the Disko for a general clean-up. I alone must hurry off radiograms before the vessel sailed and make necessary arrangements for my party on the Fulton.

From the little dinghy we waved good-bye to the friends on the Disko and in the afternoon weighed anchor and sailed down the harbor for 
the cruise to Ivigtut. Without incident we reached the Arsukfjord and dropped anchor off the dock of Ivigtut on the afternoon of September 12.

The colony of Ivigtut exists because of the mine of cryolite, unique in the world, which is located close to the shore of the harbor. Cryolite is a very interesting mineral, a fluoride of aluminium and sodium, which looks much like compact snow and is associated with many other minerals generally of bright colors, some of which are not found elsewhere in the world. With the exception of the coal deposits north of Godhavn and the deposits of coal recently discovered on the east coast in nearly the same latitude, this cryolite mine represents almost the total mineral wealth of Greenland. The ore is mined by a company as a concession from the Danish Government, and is very ably managed. About two-thirds of the ore is shipped to Copenhagen, and the remaining third to Philadelphia. The material is used in the production of aluminium and aluminium alloys, in preparing enamel, and in other ways.

Promptly upon our arrival we were initiated into those extraordinary hospitalities which were provided for the rescued men and were to take on still greater proportions in Copenhagen and New York. The President of the Cryolite Com- 


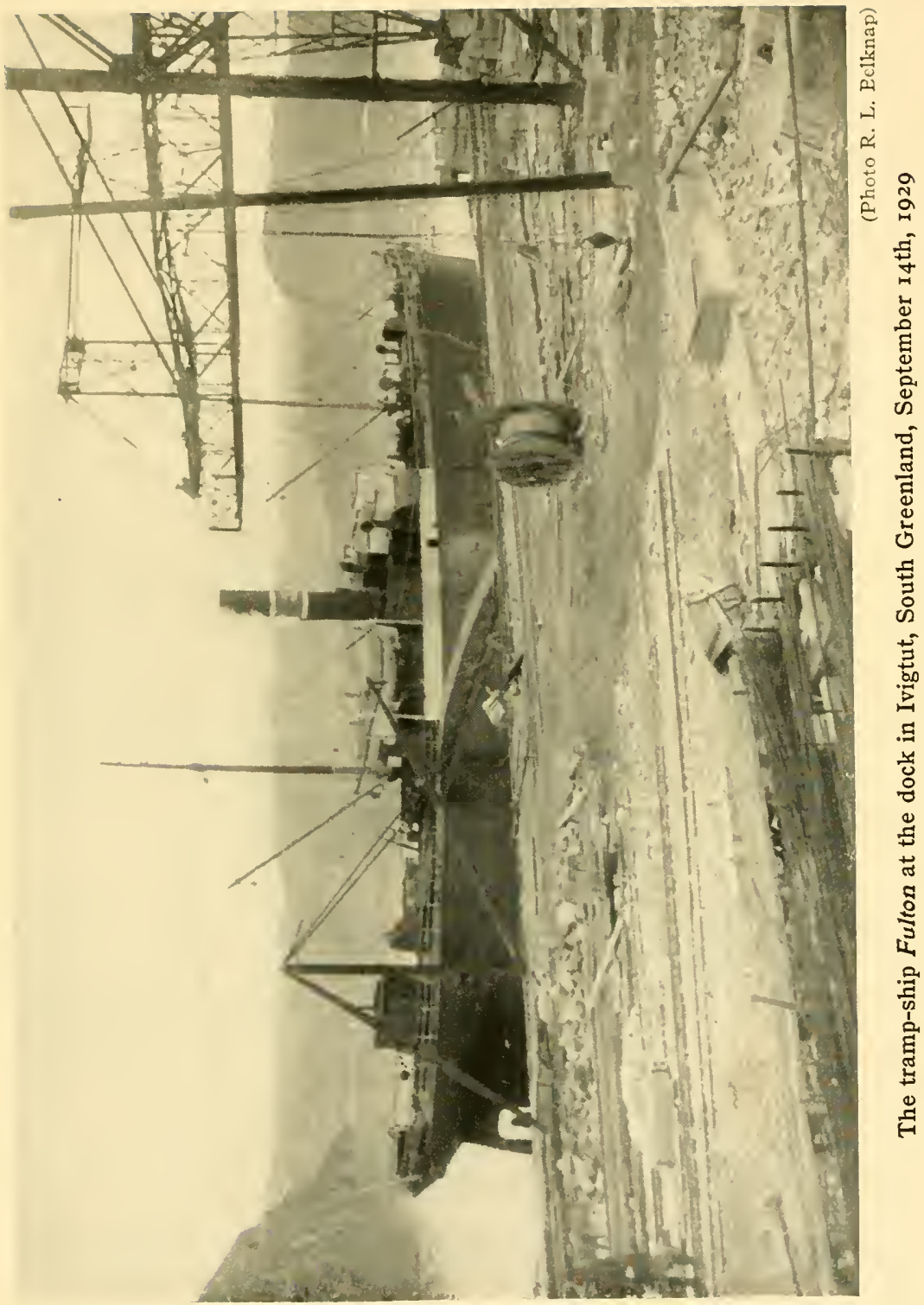



pany, Mr. Nils Jagt, I had already met as a guest of Dr. Rasmussen in Copenhagen, and as soon as the anchor was let go, his secretary came aboard with a courteous note apologizing that because of a lameness he could not himself greet us at once and requesting the names of the members of the party. These were furnished and soon afterwards there came personal invitations for all of us of the expedition, as well as the captain and mate, to attend a dinner at the Ivigtut Club House the same evening. We were just a little amused by the dress indicated as suitable. In the corner of the card was the penned word, "Smoking", which on the continent of Europe means "dinner coat".

By chance my personal trunk had been on top in the hold of the Nakuak and it came out without a wetting, but I was the only one provided with the proper garment. I decided to wear a black sack suit, and we had some difficulty in fitting out our company with proper garments, which were at least reasonably clean. Suit-pressing establishments had not been available along our route, and our clothes had been slept in since leaving Camp Lloyd. Hassell and Cramer had only what was on them when flying, but $\mathbf{I}$ was able to loan Hassell a coat. 
The Ivigtut Club House into which we were ushered would have done credit to an American city of the first rank. The members of the Club all appeared in dinner coats exposing immaculate shirt fronts. The food and the wines were the choicest, and the napery, the flowers, and the favors were those of a fashionable banquet hall. A few ladies were present to grace the occasion, and as I looked down the line of well starched shirt fronts with the members of our own party sandwiched in among them, I was inclined to rub my eyes so as to make sure that I was not dreaming. After all, our people in their rough costumes represented the Greenland that we knew, and the men around this board-engineers, architects, and mining experts, obviously drawn from the best professional classes of Europe-constituted an enclave set in the ruder ensemble of the country.

Mr. Jagt had insisted that I be his personal guest in his beautiful home, where I could luxuriate in a warm bath and sleep in a comfortable bed. To once more array myself in the clothes of civilization, was to feel that I had already in some measure entered upon the outer world beyond the sea, and this was not disagreeable after our recent experiences. The second day of our stay we were taken down into the mine, and in the evening the 


\section{ABOARD THE TRAMP-SHIP FULTON}

entire party were the guests of Mr. Jagt at a dinner in his home. Our eyes opened wide as we saw

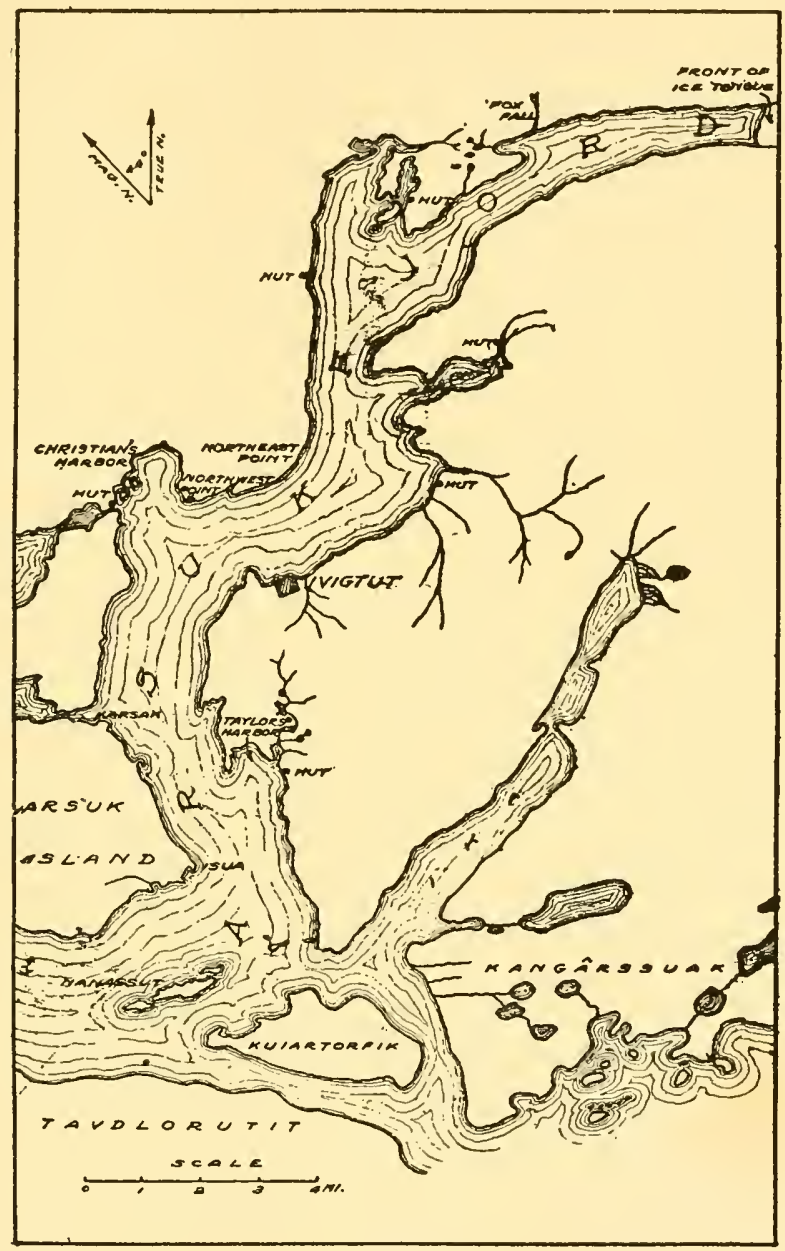

the iced grapefruit with marischino cherries and the most delicious of honey-dew melons. These had 
not of course been grown in Greenland, where the short summer season permits the cultivation of only a few radishes and a little lettuce, but their presence was explained by the contact with the United States through the Philadelphia ore boats.

There were other delicacies which were not exotic. A dish in flavor resembling somewhat a sweetbread, but more delicate, Mr. Jagt asked if we knew. Some of us had already made its acquaintance at Holstensborg, though not of equal quality. It was a local product of Greenlandthe skin of the white whale called mátak by the Eskimos. After the dinner we adjourned to the public hall at the settlement, and Hassell gave a talk on his flight which was translated into Danish and summarized by Mr. Jagt.

On learning that I was anxious to see the inlandice at the head of the Arsukfjord with reference particularly to its adaptability for a meteorological station, Mr. Jagt placed at my disposal a motorboat with crew and had a fine luncheon prepared. With Belknap and Stewart the greater part of the next day, our last at Ivigtut, was devoted to this excursion. The locality presents some advantages over any other that I know, and particularly because it is so easily accessible from civilization, both by way of Copenhagen and Philadelphia. It 
lacks, however, the probably unique quality possessed by the Holstensborg hinterland in which Mount Evans is located, for it does not have the desert climate with the clear skies which are characteristic of that region.

Only fourteen miles from Ivigtut a short tongue from the inland-ice comes down to tide-water, and the relatively smooth surface of the ice rises on a gradual ascent to the interior. The rocky mass outside is easily ascended to a small flat-topped area and has small lakes near. Less than a mile away the ice begins and in the northern and eastern quadrants a ninety-degree arc of ice is in view. Boulders and sod for buildings are at hand. Ivigtut has connections with the outside world each year by an average of eighteen ships, though the port is sometimes ice-bound as late as May or June. This is due to the cold current bringing icefloes and icebergs down the east coast of Greenland to double Cape Farewell and move northward along the west coast.

The motor-boat returned with us to Ivigtut so as to arrive in the early afternoon, for we were to sail at 5 o'clock. Coming into the harbor we were agreeably surprised to see in port the Scckonung, the motor-schooner of Dr. Knud Rasmussen. The ship was on its way south from north Greenland 
en route to Copenhagen and had been engaged day after day under the direction of Dr. Rasmussen searching for the flyers who were now returning with us to civilization. The ship had come into port while we were away. Dr. Rasmussen was not on board, having already left for Copenhagen on a tramp-ship just before our arrival. Earlier in the season he had gone to the Scotch University at Aberdeen to receive an honorary degree, one of many well merited honors conferred upon him. Captain Peterssen, his skipper, was carrying his arm in a sling as the result of an argument with a polar bear in north Greenland some weeks before.

At five in the afternoon the Fulton had her cargo under hatches and we steamed away from the loading pier with our good friends waving us a bon voyage from the shore. The hatches were now battened down and we steamed down the Arsukfjord into a bad western gale and for between thirty and forty miles after leaving the Umanak at the mouth of the fjord we were in a heavy trough sea. Our cargo of cryolite in the hold kept us off our beam ends, but we still lurched heavily, and as the ore was on steep surface slopes just as it had fallen from the cranes, slides of the ore would bring up against the rusty side plates of the ship with a resounding bang. The Fulton is fifty-one 
years old and of a rather slim model, having a beam of only 26 feet, and in part because of this it rolled heavily in a sea.

We passed a somewhat disturbed night. The floor of the Captain's cabin where I had my bunk was soon covered by a collection of the contents of the drawers to the lockers and the materials which had been on top. There were bottles of schnapps and other liquors which had been presented to us by our friends at Ivigtut. My ink bottle, clothes, etc., were also in the collection. Cramer, who was still suffering from the effects of his starving time, had been given the couch in the saloon. The others on the floor of the saloon rolled about like peas as the ship lurched, until they had got wedged into positions somewhat easier to maintain.

All the next day we were in this gale and when the storm moved away to the eastward and the wind fell off, the sea was still but little improved. There were no racks on our saloon table and when we were at meals and the lurches came, though every hand we could muster was in use holding the dishes, some would escape to the floor. Before dishes and food had been put on the table, all six of us would sit down, and as the dishes arrived hold them in place. It was an especially difficult task 


\section{NORTH POLE OF THE WINDS}

to manage the soup while with spread arms herding the other dishes. On the fifth day out the sea quieted, and in twelve more days we were off the port of Copenhagen.

The Fulton's radio had brought us word that a great reception was being planned in Copenhagen to do honor to the occasion. On the morning of our arrival the ship was dressed in signal flags as we came into dock before a great assembly of people. Among the company were the American Minister, Mr. Percival Dodge, generals of the army, professors in the university, and reporters and camera-men from all the newspapers. We were glad to see our friends Peter Freuchen and Helge Bangsted, who came out in advance on a tug with the newspaper-men.

And now came dinners sponsored by the Politiken, the principal daily newspaper, and by the Geographical Society, and a reception and tea were given at the American Legation. Cramer I had advised to visit the flying field at the Tempelhof in Berlin and so we flew down together from Copenhagen. As we flew over the landing field preparatory to coming down, what was our amazement to see a great American flag flying free from the top of the high flag staff over what was formerly the parade ground of the Berlin 
garrison. Chamberlain, who made the Atlantic flight and came down near Berlin, afterwards told me that when he had arrived the Germans desiring to honor him by showing the American flag, had been quite unable to find one. The problem had been solved by hastily sewing together a very small flag and hoisting it on this flagpole. The lack had since been corrected, and now the new flag was to be dedicated on Cramer's arrival.

The Scandinavian-American lines made Hassell and Cramer their guests on their further journey to New York, where a great reception awaited them. My duties called me at once to Ann Arbor, so I flew from Berlin to Paris without a stop to catch the Olympic for New York. As the plane approached Paris a thunderstorm was over the city and lightning played brilliantly about the clouds, but we just escaped the shower. Soon after our arrival a downpour came which flooded the city. I was not yet through with storms on the sea, for those which we encountered on the Olympic made it necessary for this splendid ship with its tonnage of 46,000 and fine sea-going qualities to slow down so as to prevent pounding. Only once when riding out a typhoon in the Japan sea have $I$ in a long experience seen a more angry sea. 


\section{CHAPTER XXVI}

CARLSON'S WINTER DOG-SLED EXPEDITION

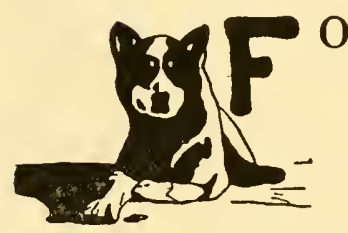

OR Carlson I had made plans before the summer party of 1928 had embarked with Hassell and Cramer on the ill-fated Nakuak to go down to the coast. He had been delegated to leave the camp the next morning with the Eskimo hunter Marius in an attempt to reach the place where the "Greater Rockford" had been left on the ice. This was in the hope that despite the stormy foehn wind which had since blown off the ice, it might still be found intact and certain parts salvaged. The navigating instruments were light and easily transported and worth at least $\$ 1000$. Each blade of the propeller was worth about the same sum. Cramer had given Carlson as full information as he could regarding the position of the plane and also that 
of the moraines which the men had followed in coming down off the ice.

The next morning Marius had come down with a serious case of the flu. This illness was doubtless from germs brought in from the coast by the crew of the Nakuak. The Eskimos are especially susceptible to colds and grippe, and on arrival of outside people they quickly contract diseases of this nature. The postponement was first until sometime in October, but later it was further put off until winter, when it could be much better undertaken with the use of dog-sleds across the frozen surface of the fjord and over the ice-cover of the lakes and rivers. Moreover, in the summer season the ice-cap itself is in the neighborhood of its margin cut into deep crevasses and thaw-water channels. These during a normal winter become healed or filled up by drift-snow which is blown into them and packed hard under the strong foehn winds which blow down the surface of the ice.

It was only because the winter of 1927-28 was the warmest in perhaps thirty years that this did not appear to have taken place, and the land outside, like the inland-ice itself, was largely bare of snow for most of the time. Otherwise Bangsted would have met with much easier travel conditions on his winter ice-cap expedition of that year. 
Carlson's expedition was eventually undertaken in the month of March, 1929. The party consisted of Carlson himself, the leader, and three Eskimos - Mathias Olsen, and Enok Jonathansen of Sarkardlitt and Hansi Olsen of Sarfanguak. Hansi and Mathias each drove a team of eight dogs, and Enok, who was both strong and enduring and had been in all three of our summer expeditions, went along as a helper.

The party left Camp Lloyd early on March 3 under a partially clouded sky and with a surface temperature of the air of $16^{\circ} \mathrm{F}$, a delightfully cool air to fill the party with zest for the journey. Instead of going southeast across the fjord in the direction of their objective, it was necessary to follow first the north shore southwestward for a distance of six miles, or as far as Second Point, so as to avoid a large open section of the fjord off Nakajanga. From Second Point the dog-sled was driven down onto the fjord-ice and pointed directly off toward the spot where Hassell and Cramer had been rescued. The south shore was then followed westward to the head of Monroe Bay, the starting point of our last summer's expedition in the caribou country.

Owing to the high tides on the Söndre Strömfjord, there is always in the winter time a tide- 
crack near either shore, and inside these cracks the ice remains during the winter frozen firmly to the shore, thus making a fixed shelf or "ice foot" on both shores between which along the tide cracks, as along the ways of a modern elevator car, the fjord-ice as a whole moves upward and downward with the flood and the ebb of the tide. Often these shelves are wide enough for the passage of the dog-sled, and they thus constitute feasible dogsled routes when no others exist.

The head of Monroe Bay was reached about two in the afternoon and the fjord was now left behind for the ascent to the divide about 1200 feet above, which separates the fjord from lake J. P. Koch. A slight and somewhat easier descent was then made to the lake which lies at an elevation of 1020 feet. This lake was the objective of the first day, so at about six-thirty in the evening halt was made there for camp. The two sleds were now unloaded, placed side by side with the uprights serving as the ridge for the tent, and over them was pitched the smoky and greasy tent which Mathias had brought along as his contribution to the expedition.

With the limited supply of food which it was possible to bring, and with only one large cooking pot, Carlson thought it best to cook for all with 
this one dish. Erbswurst was ground up for soup and oatmeal was added for thickening. This was eaten with dried pemmican and with narwhale hide (mátak) as dessert.

At five-thirty the next morning Enok was up and filled the cooking pot to the brim with ptarmigan, which had been obtained on the march the day before. The birds he had first cleaned with his hands and mouth leaving the feathers on one foot of each to make it easier to fish the birds out of the pot. To wash down the half-cooked bird each had a cup of black coffee, and when these had been drained it was found to be seven o'clock, the time to be off. The sky was overcast and the air temperature $12^{\circ}$ Fahrenheit.

Until ten o'clock the route was over the ice of the lake until its head was reached, and then over the dry bed of a winding stream which connects this lake with smaller ones farther back in the hinterland. In places the snow was here covered by wind-blown sand, making the same type of hard sledding that Bangsted had encountered and described as "sandpaper" almost exactly a year earlier on his sled trip from Camp Lloyd to the Russell Glacier.

Several small lakes included along the bed of this river course broke the monotony of the jour- 
ney, and at two o'clock in the afternoon the site of the summer camp of the Eskimo caribou hunters was reached. Leaving this lake behind, other difficult places in the river bed were met with, and between three o'clock and five only about two miles were covered. Camp was made at seven o'clock, but this time on the bare ground instead of on the sleds. It had been a hard day and all hands were fast asleep by nine o'clock. Carlson was up at midnight and found the temperature had risen to $39^{\circ} \mathrm{F}$.

By six-thirty next morning, March 5 , the breakfast was over and the start made. The traveling now became very difficult and for the first two hours hardly a half mile was made. Not even a trace of snow was on the ground, and the warm southeast foehn wind which had come during the night melted such small snowdrifts as there had been in open spots on the river-ice and these drifts were now puddles of water.

The mercury in the thermometer stands now at $40^{\circ} \mathrm{F}$. Where the river-ice is not covered with water, the surface is glassy smooth and it is next to impossible for the dogs to get traction, and it is equally difficult for the men shod as they are with kamiks to make any headway.

Carlson had been following the shore line of 


\section{NORTH POLE OF THE WINDS}

the small lakes. Between the lakes the sites of river rapids in the summer time seemed almost innumerable, and here the gigantic boulders made it necessary to drive over bare ground while going around.

As if this did not present difficulties enough, the foehn wind blowing in their faces was constantly increasing in violence. At one point they met with a cataract one hundred feet high. Here the grade was too steep to drive around it. The wind was roaring through the gaps in the mountain, and the low stratus clouds were moving out with hurricane velocity. A halt was made and the Eskimos went out a half mile in advance to see what the country ahead was like.

In his diary Carlson wrote: "Mathias and Hansi returned at ten-thirty and reported the river up ahead to be very bad. 'Their childish nature and easy discouragement have already shown themselves. Mathias pleads with me to turn back and go home. I refuse to listen to him, and declare we are going to push ahead as long as the food lasts, regardless of how slow our progress may be. With much grumbling and many "ajorpogs" (Eskimo for "no good"), they returned with me to the sleds. We are going to haul the equipment on our backs and pull it over the cataract with a rope which $I$ 
have brought along for just such an emergency. The dogs will be led around the hill.

"After two hours of back-breaking pulling and hauling we had scaled the two cataracts, and the dogs were now given a chance to pull. After a mile of travel, part of the time over the watercovered ice on the river, we halted at a fork in a meander stream. At six-thirty we pitched the tent in a driving rain. A little later when the wind had abated, I climbed a nearby hill to view the land ahead. I could not see the ice-cap, due to the low stratus clouds, but I did see that we would have several more cataracts to scale. After supper the rain ceased and the temperature began to fall."

The following is from Carlson's diary:

\section{March 6}

During the night a light snow fell which was a godsend when we had to leave the river. When we broke camp at seven-thirty we were enveloped in a dense fog that showed no signs of lifting. The temperature had dropped to $21^{\circ}$. A mile from camp we scaled the first of the cataracts which $\mathbf{I}$ had seen last evening. We carried our packs and the dogs were able to drag the empty sleds. From this point we traveled upward for several hours helping the dogs to pull the sleds. At one o'clock 
we came to a small lake where the dogs were able to work unassisted. I have been driving the dogs and find they obey my commands very well and I am able to make good time. My handling of the long whip is improving, as well as my Eskimo vocabulary. One of Hansi's dogs is a vicious, surly brute and even Hansi is afraid of him; so he says when we return he is going to hang him.

About four o'clock in the afternoon, while running along the side of a steep hill, the sled of Mathias slipped and turned over, loosening the upright and smashing the cross-piece. This necessitated a halt while a board from a pemmican box was used to repair the damage temporarily.

Camp was made at six-thirty in a driving east wind with drifting snow. After supper I dressed a finger Hansi had bruised while pounding the dogs. I had a small safety kit, at sight of which the Eskimos' eyes popped. In it among other things, was a little jar of Vaporub. They tried putting some on their noses and the resulting expressions on their faces were a mixture of surprise and glee. The grease drew blood from Hansi's nose and he said it was bad. I was glad because now they are not likely to want the process repeated. 


\section{March 7}

Sometime during the night the wind from the southeast began to blow at gale velocity and brought the temperature up to $39^{\circ}$. The snow was blowing over the lake surface and the other snows were fast melting. We were delayed several hours while having to repair Mathias's sled. At ten o'clock we were again on our way. The wind was now so strong that the dogs had to be led every foot of the way. The temperature was at $22^{\circ}$ and stratus clouds were coming rapidly from the south southeast. At noon we got our first glimpse of the glacier. Snow was blowing off in great clouds that cover the mountains. The air temperature was not low enough to dry the snow and it stuck to our clothing and there melted. To make matters worse, we were now all wet through. Travel was made difficult by a thin crust of ice on the lake, beneath which there was three inches of water. The dogs refused to go through this water, necessitating our circling the shores. The dogs' feet were bleeding and Mathias was worried about them.

One hundred yards from the ice-cap Hansi fell through some thin ice into four feet of water. Luckily he was wearing furs and I was able to get 
him out before the icy water penetrated his clothing. The contents of his sled, however, received a thorough soaking. About one in the afternoon we reached the foot of the glacier. The wind had gone down a little and we decided to ascend the ice-cap immediately. From the small lake beds we were on we found a moraine leading up to the surface of the ice. The driving snow made visibility poor, but I was able to see the lake named Taserssiak and the ice-arm near it but about two miles to the south. We fought the wind along the moraine for several miles. The ice was neither fissured nor crevassed. Long rolling hummocks bordered the moraine, but we had a comparatively easy time. At six o'clock we were about ten miles inside the ice edge and we now decided to make camp in the lee of a small nunatak-an island of rock within the sea of ice.

Outside the wind is blowing great guns and inside it is none too comfortable. I estimate that we are now probably four miles from the location where we had expected to find the plane. Several times during the afternoon we sighted the third of the three moraines which were followed by Hassell and Cramer on their descent from the ice. The surface of the ice is wet and slippery as there is only a trace of snow on the leeward side of the 
larger hummocks. Footing is treacherous, but the dogs seem to be able to find plenty of traction.

\section{March 8}

We were up early this morning and found the wind had gone down a little, though the temperature was still high, $28^{\circ}$. Early in the morning two of the dogs ate the traces on their harness, but Enok was able to catch one of them. The other dog escaped and Hansi fears that he will rob our cache of meat which is on the back trail. We decided to leave Enok with the dogs while Hansi, Mathias and I went out in search of the plane. The wind made progress difficult, but the generally even surface of the ice aided our progress. We have not yet encountered a single crevasse. After two hours of travel we reached the moraine which I was given as a landmark. The plane from this location should have been about two miles to the east southeast. The rolling hummocks here are deeper than those near the nunatak and the depressions hold more snow. The snow is moreover hardpacked and in places as much as four feet deep. We spent four hours in the vicinity where we expected to find the plane. We separated and searched up and down, but no trace of it was to be found. 
After a light lunch of dry pemmican we went still further out on the ice but had no luck. Not a trace of the plane! Where it could be is beyond me. There are no crevasses or fissures and the snow is not deep enough to cover a large plane. My conjecture is that the storms with high winds have torn the plane to pieces and scattered the parts. At five in the evening we returned to camp tired and disappointed.

\section{March 9}

The wind is still blowing from the southeast. At midnight the temperature had dropped to $22^{\circ}$. Early in the morning we got up and the three of us again walked out to make another search for the plane. About four hours were spent in this search. The high winds and the blowing wet snow made our task difficult. At one in the afternoon we returned to camp, loaded our sleds, and started on the long trek homeward. With the gradual descent we made fast progress and covered the ten miles from the nunatak to the ice-edge in four hours.

\section{March 10}

Puddles of water on the lakes and rivers make sledding very bad. While passing over the sur- 
face of a lake the wind caught Mathias's sled and ditched it, and because of the smooth ice he was unable to get proper footing and the sled slipped sideways, coming to a stop when the runner hit an embankment and cracked. A half hour was spent making the repairs.

\section{March 11}

The wind all day has been from the southeast and east southeast with the clouds from the south. The temperature has been $24^{\circ}$. The ground is entirely barren of snow and sledding is hard. Early in the evening the wind direction suddenly changed to west bringing an intermittent snow-fall, and at nine o'clock the mercury had dropped to seventeen degrees. Clouds are now coming from the west.

\section{March 12}

The temperature kept going down all night and at four-thirty this morning when we got up it had dropped to three degrees below zero, which is the lowest temperature we have experienced during the entire trip. We reached the shore of the Söndre Strömf jord at ten in the morning and there the temperature was five degrees above zero. The observatory on Mount Evans was reached at four 
in the afternoon and I reported to the boys the disappointing news. Karl's first remark upon seeing us was that I smelled just like one of the Eskimos.

Thus was brought to a conclusion an arduous winter trip carried out by Carlson with determination and hardihood and with excellent judgment throughout. In such winds as blow down the slopes of the inland-ice the plane had probably been carried far from its original position and been wrecked in the process.

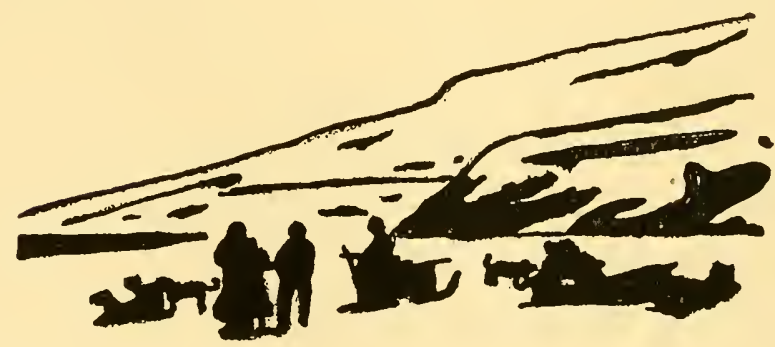




\section{CHAPTER XXVII}

OUR WIRELESS STATION'S ACTIVITIES

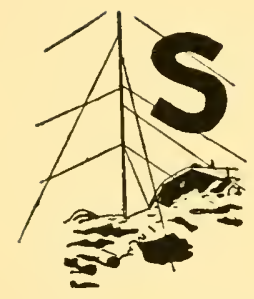

INCE the advent of wireless, polar exploration has been profoundly transformed. The radio was first put into service in polar exploration, I believe, by Sir Douglass Mawson in his Antarctic Expedition of 1911-14; but this was before the day of shortwave wireless, and the erection of the high mast and the powerful plant at his base station and a similar one at the halfway station of Macquarie Island was a very arduous operation. Expensive as this undertaking was, and too ineffective in operation when measured by present-day standards, it none the less played a very important part in the scientific work of the expedition and also in keeping up the morale of the men. Before the 


\section{NORTH POLE OF THE WINDS}

era of wireless the ennui of the personnel of polar expeditions throughout the long dark and depressing "polar night" taxed the resources of commanders to overcome.

Today with the use of short-wave radio we have demonstrated the practicability of directing a station in the Arctic throughout the long winter night from the campus of the University of Michigan. This station has been that of the Military Department of the University in charge of Lieutenant Richard T. Schlosberg, U. S. A., but operated by students of the Signal Corps section of the R. O. T. C.

Few of the inhabitants of the city of Ann Arbor have realized when they have passed the southeast corner of the University campus on some winter evening and have observed an intermittent sparking on a wire above their heads, that this was carrying a message directly to the weather station on the summit of Mount Evans in the interior of Greenland. Our schedule has usually been maintained throughout the past two years on Monday, Wednesday and Saturday evenings from October to May or June, and by special arrangement on many other nights. The communications have sometimes been interrupted by the aurora borealis, which blankets the short-wave signals much more 


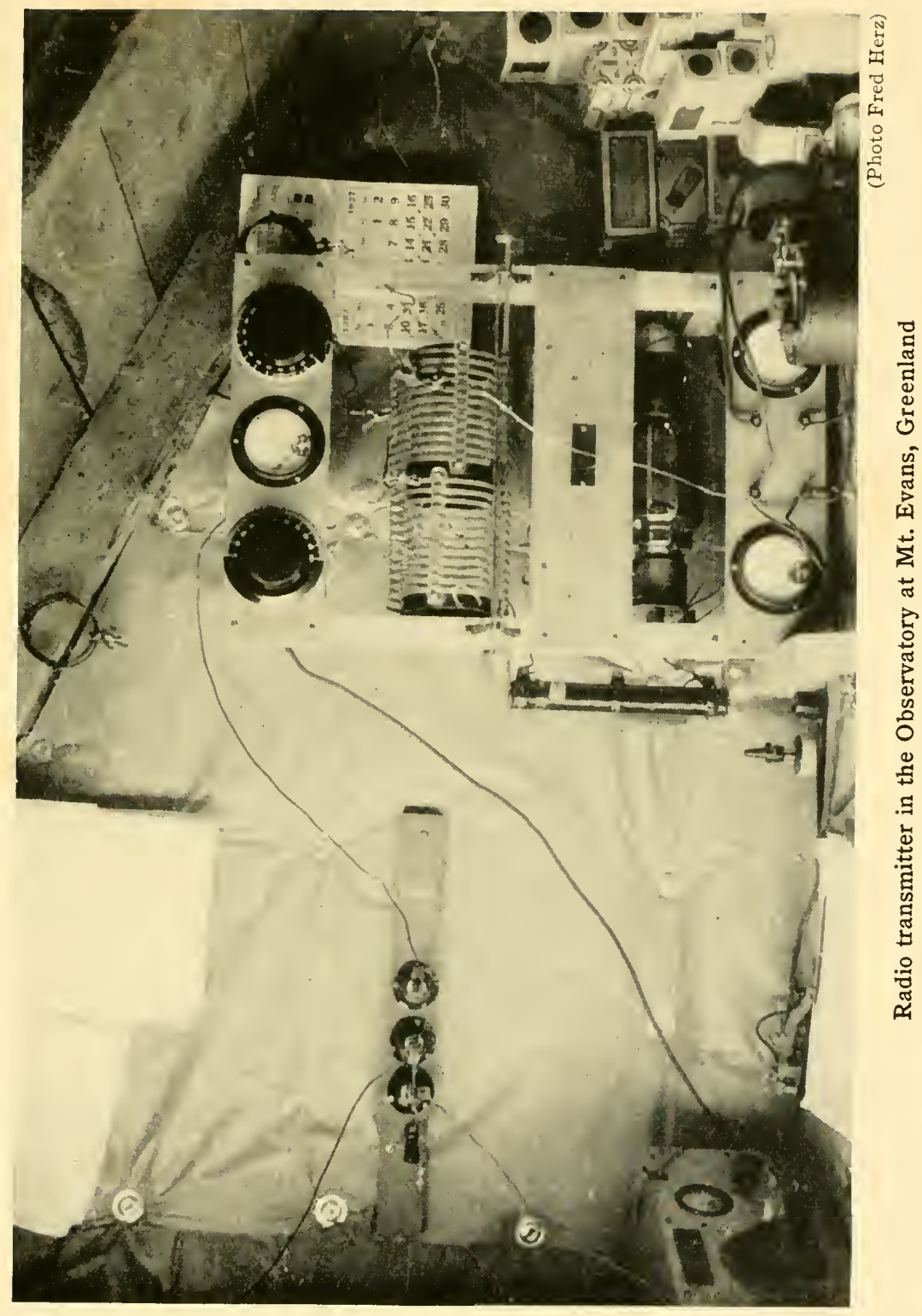


than the long-wave ones. There was a long interruption of our radio communications from May till July in 1928 which grew out of the episode which $I$ am about to relate.

Before doing so I may point out that the shortwave plants are usually much more efficient over long distances than are long waves, and they are also very much less expensive to install and operate because less energy is required for the transmitter. Careful estimate by an expert of the engineering division of the Navy Department for a long-wave radio plant to equip our Greenland station was $\$ 11,000$. The short-wave plant actually erected would have cost less than one-third of that amount had we been compelled to purchase all the materials outright, and it has cost very much less because of generous gifts of special parts and because the services of John Reinartz, who designed the plant, were generously given us.

In the summer time with continuous daylight our operator had much difficulty in maintaining contacts, and these have sometimes been most embarrassing because not understood by men in charge of other stations.

In the summer of $\mathbf{1 9 2 7}$ the very efficient radio operator on the motor-ship Disko which took our expedition to Greenland, was a young lady, the 
only one, I believe, in the service. The radio plant of the Disko, like that of other Government vessels plying between Copenhagen and Greenland, is a long-wave one, as are those of the six stations on the continent of Greenland itself. These stations are located at Julianehaab (Chief Station) in south Greenland, Godhavn, Godthaab, and Ivigtut on the west coast; and Angmagssalik and Scoresby Sound on the east coast.

We maintained at the Mount Evans Station in addition to our full short-wave set, a receiver for long-waves. We were thus able to pick up messages from long-wave plants, though we could not make reply to them. It had been arranged with the young woman in charge of the Disko wireless to send us a message when the Disko should be off the Greenland coast on its third cruise northward. This was almost necessary in order that we might get ready to go out to the coast and be in time to embark on the vessel. This service she did, and as $\mathrm{I}$ was about to leave the station, $\mathrm{Mr}$. Oscanyan, our operator, came to me bringing a duplicate short-wave receiver which was his personal property, and asked that I deliver it to the lady operator on the Disko. By doing this, he explained, it would be possible for me to maintain contact with Mount Evans during this passage out 
to Copenhagen. This seemed to me an excellent arrangement, and I complimented Oscanyan on his thoughtfulness and generosity.

The matter passed out of my mind until shortly after leaving Holstensborg on the Disko, when the radio operator came to me with the somewhat startling news that she was now engaged to $\mathbf{M r}$. Oscanyan. A light began now to break over me. Though I had delivered to her a letter of "instructions" together with the instrument, I had no doubt that other matters of great intimacy had passed to the lady and been received on the shortwave receiver. The "Yes" had no doubt gone out in long-wave to be received at Mount Evans on the station's long-wave receiver generously loaned us by the Radio Corporation of America, which was thus, I suppose, a party to the proceedings. Mr. Oscanyan sent out the news of this contract by short-wave radio to an amateur station at his home in New Jersey, but it was picked up by another New Jersey amateur operator, and since affairs of the heart seem to possess large news value, the full story appeared on the front page of the New York Times and other metropolitan papers, as well as in the papers of Copenhagen.

For me the affair had a more serious side since 


\section{NORTH POLE OF THE WINDS}

it resulted in our station being cut off from the world for several important months. Mr. Oscanyan left the station at the first moment when he could get away, which was in the following March, so as to catch the first boat of the year to Copenhagen. Since that time our radio plant has once more been used, I understand, to arrange a marriage engagement, but in this case without any loss to the station's efficiency.

Not fully realizing the part to be played by our radio plant during the long winter, or the great activity required by the scientific work laid out, I had feared that the long and constant association of two or three men within cramped quarters might lead to unpleasantness. I had therefore placed on the library shelf as a warning a copy of O. Henry's "The Book of Hymen", which described in humorous fashion the troubles of two frontiersmen who were marooned during a long storm within a lonely cabin in the mountains.

Of the great service which the radio performs we are first made aware when we find ourselves unable to use the station for some special purpose. The coast settlement of Holstensborg in spite of its recently acquired importance in the halibut fishing industry, is still without a radio plant; but like most other coast settlements in Greenland it 
can receive messages through a voice broadcast from the radio station at Godhavn, the capital of North Greenland.

Every afternoon at five o'clock the natives can be seen gathering about the door of the Governor's house, where he may be seen with the telephone headpiece sitting before a radio receiver. All important news of the day, and with it any radio messages as well, come in by the voice of Mr. Holton Möller, the government's very efficient radio operator at Godhavn. On rare occasions when a ship lies in the harbor, but only then, answers to these messages can be returned over the ship's radio.

During the winter of 1927-8 the following radio message reached me at Ann Arbor from Mr. Oscanyan: "Please tell Governor Bistrup that the dog-sleds will start back Monday". I realized the necessity of having this message go forward, because the winter having been exceptionally warm, the fjord between Holstensborg and Sarkardlit was probably not frozen, and the motor-boat would have to be sent in for the returning dog-sled party. My message to the Governor went by cable to London and was forwarded by cable to Reykjavik in Iceland, from where it went out by longwave wireless to Julianehaab near Cape Farewell 


\section{NORTH POLE OF THE WINDS}

in extreme southern Greenland, to be there relayed to Godhavn, the capital of North Greenland. At five o'clock Mr. Möller at Godhavn would then broadcast it in the Danish language, and Governor Bistrup listening in could hear it on his receiver. Thus by a route of $\mathbf{2 , 0 0 0}$ miles from Mount Evans to me and by an additional 7,000 miles or more of slow motion the message would bridge a direct distance of less than $\mathbf{1 0 0}$ miles. Mr. Möller would then kindly broadcast it in the English language, and our people at Mount Evans would thus learn that their message had gone through safely to the Governor.

In the spring of 1929 Commander Byrd in his station in "Little America" within the Antarctic, tried to send a message to me at our Ann Arbor station. At other times messages had come through without difficulty, but on this night there was considerable static and the message could not be heard. It occurred to Mr. Hansen, Byrd's radio operator, to forward the message to our station in Greenland 12,000 miles distant where there would probably be less disturbance, and have them relay it to us in Ann Arbor. Under these conditions the message went through without difficulty. A curious feature which caused interest and a little confusion was that the message was sent from the 
Antarctic by a Mr. Hansen and relayed to us by our operator Hansen in Greenland.

Our Greenland station employed a 250 watt transmitting tube supplied with 2000 volts of D. C. current for plate excitation and 16 volts D. C. for filament excitation. The power was supplied by an electrically driven motor generator which in turn derived its power from three large "ironclad" storage batteries. The mast was of bamboo in five seven-foot sections joined by ferrules. This mast weighed about 25 pounds and was easily transported by one man. In service at Mount Evans it withstood wind at ninety miles per hour before collapsing, and after repairs was competent to withstand wind of only seventy-five miles per hour. The motor-generator was housed under a bench which served for seats in the main room of the hut.

Communications with Europe and with the American stations generally was during the first year on 45 meters, though later changed to 34.5 meters.

The above description refers to the operation during the first year, 1927-28. The Third Expedition took in a new motor and transformer, so as to change from direct to alternating current and greatly strengthen the transmission. Mr. Francis M. Baer, who had gone in with the Third Ex- 
pedition as radio operator, came out on the last boat of the year and was replaced by Karl D. Hansen of Copenhagen, an exceptionally competent operator. Under his management the plant was given a severe test during the summer of 1929 in connection with the flight of Colonel McCormick's amphibian plane, the "'Untin Bowler", in its attempt to reach Europe by flying across Greenland. As one of its co-pilots it had on board Parker Cramer who had been the navigator for Hassell the preceding year. As in the Hassell flight, Mount Evans was chosen as a way-station and our winter staff consisting of Schneider, in charge, Hansen and Schmeling, made all preparations for the reception of the plane at Camp Lloyd.

The station of the Military Department of the University at Ann Arbor in charge of Lieutenant Schlosberg and at the time operated by Fred W. Albertson, was nightly in operation transmitting messages from the office of the Chicago Tribune directly to Mount Evans and receiving replies from there. This was in the summer season when transmission from Ann Arbor was generally possible only after ten o'clock in the evening, although Mr. George H. Pinney at his station in South Manchester, Connecticut, was able to transmit an 
hour earlier because of the earlier coming of darkness farther east. Mr. Pinney's station has been second only to the Ann Arbor one in its importance in maintaining contacts with Mount Evans throughout the year.

In the critical stage of the flight when the plane was down somewhere in the Hudson Bay country, the transmitting condenser of the Mount Evans radio plant burned through, sending heavy currents through the generator and changing the polarity of the output. The plant was out of commission for about twenty-four hours, but thanks to Hansen's skill in supplying effective makeshifts it was soon again in order. A little later contact ceased altogether, just as radio connection had been established between Mount Evans and Port Burwell, where the plane had arrived, and where it was necessary to send weather reports. For almost a week failure to obtain contact continued, and when it had at last been re-established, no explanation could be offered except that of "fading". For entire reliability at all times a combination with the far more expensive and cumbrous longwave system seems under the present state of our knowledge to be essential. It has already been pointed out that with the aurora the short-wave signals are much more blanketed than are the long- 
waves. Had the plane not been delayed for a number of days by bad weather at Port Burwell and then met disaster by drifting out of the harbor and crushing in the ice, this failure of our plant at a critical time would have been far more serious.

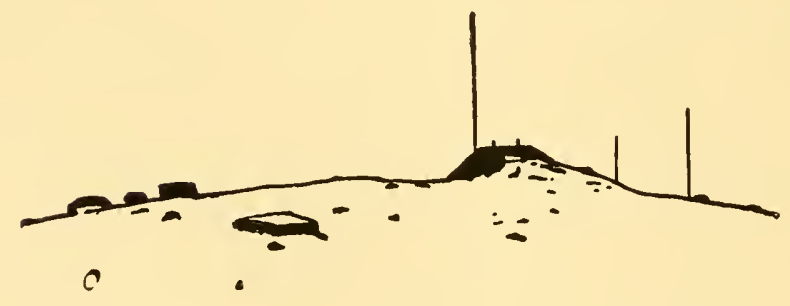




\section{CHAPTER XXVIII}

THE CLOSING OF THE STATION

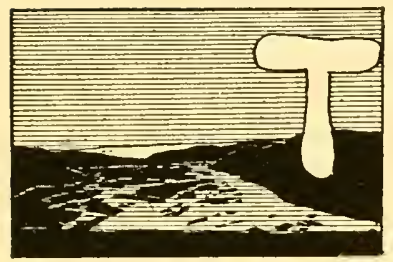

HE weather station at Mount Evans was set up to learn the nature of the upper air circulation over and about the great northern ice-cap, and its relation to the greater atmospheric disturbances about its borders. It was never the intention to personally conduct the station beyond what would be necessary to learn correctly the nature of this circulation, though it was fully realized that such a station should be maintained permanently by some national or international organization. It was the intention to close the station when two complete years of continuous observation had been made.

The regular daily balloon and other observations were begun at Mount Evans on July 21, 1927, and the two years were completed on July 21, 1929. 
After that date the staff gave their attention to closing up the station while leaving both the meteorological and the wireless plants as nearly as possible ready to open up again in the future. Non-perishable provisions were carefully stored, instruments packed for preservation, and the several buildings locked up. The old radio shack at Camp Lloyd was, however, left unfastened to be used as a refuge for Eskimo hunters, who in the winter come in from the coast by dog-sled to trap the blue foxes that are so abundant in the neighborhood. Placards kindly supplied by Governor Rasmussen and written in the Danish and Eskimo languages were placed on the doors of all the principal buildings, and this will doubtless insure them from depredation, though the Eskimos are not given to pilfering.

On July 29 the staff left Mount Evans and reached Copenhagen aboard the Disko on September 19. The records of observation have now all reached Ann Arbor and are being prepared for publication.

Due to the steppe-like climate of this little protected area of the hinterland lying under the lee of the great Knud Rasmussen ice-arm-the annual precipitation is about five inches-fogs are hardly known and clear skies prevail almost 
throughout the year. It is for this reason that in just two years no less than 776 ascents have been made with pilot balloons, whose paths have been followed to an average altitude of about four miles, though exceptional runs were made to sixteen and nineteen miles, and to distances of as much as thirty miles. At the station on the Maligiakf jord occupied in the summer of 1926,94 balloon runs were made.

Because of the local protection from those cyclones which move up Davis Strait and give up their moisture before arriving in the hinterland, Mount Evans possesses unique advantages for a flying base on the route from America to Europe. The width of the single span from coast to coast across the Atlantic is so great that for presentday planes all available loads must be given over to fuel and crew. No reserve is left for the pay load which is necessary to make such flights commercially profitable. For the northern route over Greenland such is by no means the case. By this northern route an excessively long hop of nearly 4,000 miles is broken up into a number of moderate to short ones, the longest less than 1000 miles, and the longest continuous one over the sea only about 800 miles. This route brings the Great Lakes cities almost as near to Europe as New 
York, since the northern route more nearly approaches to a great circle of the earth.

The northern flying route calls for an amphibian type of plane, because the terrains flown over in Canada, Greenland, and Northern Europe were all once covered by glaciers and in consequence they are now occupied by such myriads of lakes that a forced landing would be possible for a seaplane almost throughout. Difficulties to be met with upon this route are especially the fogs, particularly those near the shores of Labrador, Greenland, and Iceland; high ranges of the tide upon the sea, and floating ice. Fogs are however, probably no worse on these sea stretches than they are along the steamship routes, where the Labrador current and the Gulf Stream are in contact for long distances.

The hop-off from America to Greenland should be made from the Hudson Bay post of Northwest River at the western end of the long Labrador fjord, the inner portion of which bears the name of Lake Melville and the exterior portion Hamilton Inlet. Lake Melville has a narrow entrance from the sea which prevents the ingress of seaice and it has moreover a tide range of only about four feet. Moreover, the inner end of this lake 
is but little subject to fog, though sometimes wrapped in smoke from forest fires.

Since the immediate coast-land of Labrador is for much of the time wrapped in fog, largely due to the cold Labrador current which skirts it, and the fleets of icebergs and ice-floes which are borne along with it; were it necessary for an aviator to wait at Melville Bay until the coast was clear of fog, the time necessary to reach Europe might easily be so long as to offer no advantages over other means of transportation. Fortunately, the great ice-cap of Greenland is apparently always clear of fog, and its white expanse is so vast that it could not be missed by an aviator, even if his plane should be carried some hundred or more miles off his course. Once past the Greenland west coast, if he does not immediately come out of the fog, the aviator will do so when he reaches the border of the inland-ice; and the grand scale of the tongues passing out from its margin, as well as the deep and wide fjords which cut into the land outside, should make it easy for him to find his position upon the map. In his flight during the summer of 1928 Hassell flew in cloud the entire span of Davis Strait and arrived on the Greenland Coast 250 miles off his course to the southward. None the less he was able to find his position upon 


\section{NORTH POLE OF THE WINDS}

the map and, turning northward, follow closely the border of the ice-cap until with fuel exhausted he was forced down only 70 miles from Mount Evans.

Two great landmarks of the Greenland southwest coast are the white arms of ice which push out westward-the Frederikshaab isblink, which comes down to the sea in latitude $621 / 2{ }^{\circ} \mathrm{N}$, and the Knud Rasmussen ice-arm in latitude $66^{\circ} \mathrm{N}$. high upon a plateau. These two arms of ice are the only ones which come near the sea and they are nearly 250 miles apart. Almost exactly half way between them is the great radiating fan of fjords surrounding the southern capital, Godthaab, and these fjords extend far inland to the ice-cap itself. Both because of their size and their peculiar plan they have no parallel for hundreds of miles in either direction and so can easily be identified from the air.

Flying at an elevation of 5,000 feet so as to clear the highest peaks of the coastland, the aviator as he comes over the margin of the ice-cap will encounter a southeast wind, and turning to the north will fly with the tail wind until he arrives at Mount Evans and makes a landing off Camp Lloyd on the margin of the fjord.

The Greenland ice-cap is without mountains ex- 


\section{THE CLOSING OF THE STATION}

cept those which lie close to its border, and for the most part it is almost as flat as a ball-room floor. Along the route from Mount Evans eastward to Angmagssalik the ice plateau has a maximum altitude of between eight and nine thousand feet, and it should be quite possible for the aviator to navigate safely by the use of his altimeter. Away from the margin the snow is so smooth as to be in most cases without shadow, and so the aviator's distance above the surface would be difficult to gauge in the usual way.

The hop from Northwest River in Labrador to Mount Evans, Greenland, is from 900 to $\mathbf{1 0 0 0}$ miles in length according to the route followed. From Mount Evans after crossing the ice-cap and passing Angmagssalik the course is taken to Reykjavik in Iceland, a distance of something less than 900 miles. Reykjavik has already several times been used as a seaplane base for trans-Atlantic flights and has already been considered for the terminus of an extension of the German airplane network. Angmagssalik now has a long-wave radio station to report the passage of a plane, and the place can easily be supplied with gasoline, since it has steamer connection with Copenhagen once each year, usually in August or September. Its harbor is, however, closed from the sea by ice 


\section{NORTH POLE OF THE WINDS}

for a large part of the year, but is generally free throughout September and October, as well as for much of the time in August. It could probably eventually be made into at least an emergency stopping place.

From Reykjavik it is 850 miles to Edinburgh on the way to London, and, if desired, by a slight detour the Faroes could be made an intermediate stopping place. A safe landing could undoubtedly be made upon the ice-cap of Greenland itself within zones each at least 100 miles in width on either side of the central area. Within these zones the snow surface of the ice is packed so hard as to leave no tracks from sledges passing over it. The central area of perhaps one hundred miles in width is covered over with deep and mealy snow on which landing would probably be more difficult. Within the marginal zone some fifty or more miles in width, the slope of the ice is steep and is covered by crevasses or by deep water channels. None the less Hassell was able in the summer of 1928 to make a safe landing at an estimated distance of about ten miles only from the western ice margin.

The peculiar air circulation of Greenland which has already been described, is such that the aviator by regulating his altitude can probably cross in either direction with a tail wind for much of 
the distance. We know that the surface winds always blow outward from an interior area of calms down the slope, though deviated always by earth rotation in a direction the same as that of clock motion. Such a circulation of surface winds implies of course an interior area of calms where the air is settling, and such calm conditions accompanied by intense cold have been encountered in the interior by those explorers who have already crossed the ice-cap on sled journeys.

Our studies with balloons on the southwest coast have told us that there are at higher levels in-blowing winds, and one expedition in far northeastern Greenland has shown the presence of such higher in-blowing winds on that side of the ice-cap. We lack as yet in published works satisfactory observations from the southeast coast of Greenland, but there is reason to believe that the high in-blowing winds will there be found and that the entire circulation over the ice-cap is similar to the outline of an hour-glass. (See p. 47.)

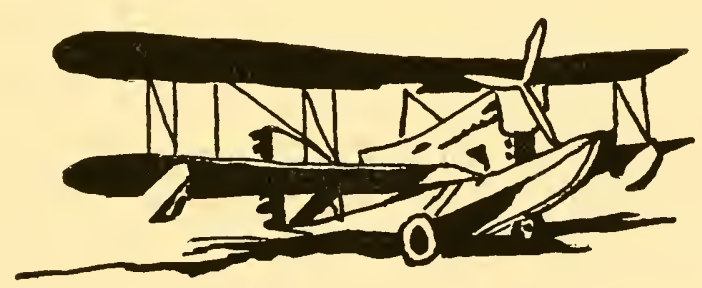

365 



\section{APPENDIX}

LIST OF BENEFACTORS OF THE GREENLAND EXPEDITIONS OF THE UNIVERSITY OF MICHIGAN

The funds for the support of the three Greenland Expeditions of the University of Michigan have been raised by solicitation of the director, and these amounted on January 1, 1930, to the sum of $\$ 55,405.66$; something over one third of which was donated by alumni of the institution. A list of the donors follows, alumni members being indicated by an asterisk:

Daniel Guggenheim Foundation for the Promotion of Aeronautics, New York City, $\$ 10,000$; James B. Ford, New York City, $\$ 5696.60$; *Roy D. Chapin, Detroit, $\$ 5375$; * Chas. F. Brush, Cleveland, $\$ 5000$; New York Times (news contracts), $\$ 2700$; Edward S. Evans, Detroit \$2375; *James R. Offield, Chicago, $\$ 1500$; *James R. Monroe, Orange, N. J., \$1500; Walter S. Case, New York City, $\$ 1500$; * George L. Ohrstrom, New York 


\section{APPENDIX}

City, \$1500; William H. Hobbs, Ann Arbor, $\$ 1474$; *Robert P. Lamont, Chicago, $\$ 1000$; ${ }^{*}$. E. Thomason, Chicago, $\$ 1000$; *Willard M. Clapp, Cleveland, $\$ 1000$; Fred M. Alger, Detroit, $\$ 1000$; C. S. Mott, Detroit, $\$ 1000$; S. D. Waldon, Detroit, $\$ 750$; *H. Earl Hoover, Chicago, \$750; *Howard E. Coffin, Detroit, \$700; *Charles H. Morse, Chicago, \$700; *Edward A. Sachs, New York City, $\$ 600 *$ Harold H. Emmons, Detroit, $\$ 600$; Charles B. Van Dusen, Detroit, $\$ 525$; James Couzens, Detroit, $\$ 500$; *D. M. Ferry, Jr., Detroit, \$500; Truman H. Newberry, Detroit, $\$ 500$; John Newberry, Detroit, \$500; *W. B. Thom, New York City, $\$ 500 ;$ W. B. Mayo, Detroit, \$350; *Henry Wollman, New York City, $\$ 300$.

George M. Holley, Edward R. Loveley, James M. Evans, of Detroit, and *Ray P. Hoover of Chicago, $\$ 250$ each.

*William J. Gray, G. D. Pope, A. A. Templeton, of Detroit; Herbert H. Dow of Midland; and *Charles E. Merrill of New York City, $\$ 200$ each, *John R. Russel, Detroit, $\$ 125$.

P. W. A. Fitzsimmons, *James T. McMillan, Frank McMath, *Wm. H. Murphy, Alex Dow, C. W. Harrah, Duncan Stewart, E. B. Whitcomb of Detroit; *William S. Davidson, Hjelmar Herz 


\section{APPENDIX}

of New York City; Mrs. A. W. Kimball, *Walter Cahill, Lynn A. Williams of Chicago; and V. E. Edwards of Worcester, $\$ 100$ each.

*W. W. Tefft of Jackson; C. B. Fritsche of Detroit, *Earl Babst, *John Prescott and John C. Parker of New York City, $\$ 50$ each. ${ }^{*}$ H. O. Evans of Pittsburgh, *T. H. Hinchman, F. G. Quisenberry, *W. T. Barbour of Detroit, $\$ 25$ each. $\quad$ R. H. Upson and *Guy S. Greene of Detroit, $\$ 10$ each.

The Treasurer of the University of Michigan has been Treasurer of the Trust Fund created and his department has kept the accounts of the Expedition. Orders for merchandise have generally been made through the Purchasing Department of the University; but since Greenland has no currency, all expenses made while on Danish ships or in Greenland, as for instance, when Danish vessels have been chartered, certain supplies purchased from Government officials, or natives employed; these have all been upon orders drawn upon credits established by the deposit of drafts with the Danish Government in Copenhagen. For these disbursements accounts are often rendered long afterward.

Except for the generosity of various scientific organizations and of many manufacturing concerns, it would have been found impossible to carry 
out the three expeditions upon the sums of money contributed.

The U. S. Weather Bureau, Dr. Charles F. Marvin, Director, has generously loaned meteorological equipment from its reserve stock, and furthermore co-operated by the loan of members of its staff, the expedition taking over their salary and expenses while employed. Mr. S. P. Fergusson has, however, since his term as a member of the Expedition in Greenland voluntarily acted in an advisory capacity and has given generously of his time outside of office hours. The U. S. Coast and Geodetic Survey, the Surveying and Electrical Engineering departments of the University of Michigan, the University of Nevada, and the Meteorological Institute at Copenhagen have all loaned the expeditions valuable equipment.

Manufacturing concerns which have supplied equipment either as gift or as a loan are the following: The Burgess Battery Company, the Allen B. Cardwell Company, the Jewell Electrical Instrument Company, the General Radio Company, the Radio Corporation of America, the Exide Battery Company, the Corning Glass Company, the Lockwood Motor Company, the Wood Conversion Company, the Taylor Instrument Company, the Mirakel Optical Company, the Geophysical Re- 


\section{APPENDIX}

search Corporation, the Weston Electrical Instrument Company, the Leitz Optical Company, the Hamilton and Waltham Watch Companies, the W. and L. E. Gurley Instrument Company, the Julien P. Friez Company, the Monroe Calculating Machine Company, the Brooklyn Thermometer Company, and the O. D. Morrill Company.

Food products for use of the Expeditions have been contributed by the following firms: The Swift Packing Company, Armour and Company, the Horlick Company, and the Borden Company.

To many individuals the Greenland Expeditions owe a debt of gratitude. Prominent among these are $\mathbf{J}$ ohn L. Reinartz and George H. Pinney, both of South Manchester, Connecticut; and Holten Möller, the efficient radio operator at Godhavn in North Greenland. For efficient aid in the financial campaign the Expeditions are indebted to Edward S. Evans and Carl B. Fritsche of Detroit. To Dr. Mortimer E. Cooley, the genial and much beloved dean emeritus of the Engineering College of the University of Michigan, the debt for advice and sympathetic appreciation is a large one.

The Expedition staffs have been drawn in large part from young men of promise either in subordinate positions in university faculties or from students who have not completed their college train- 


\section{APPENDIX}

ing. To them for whatever of good has or is yet to come out of these scientific expeditions the credit is very largely due. They have proven themselves a remarkably fine group of young men. 


\section{INDEX}

Almsted, Captain, 314

Angmagssalik, possible flight station, 363

Arsukfjord, 321-323

Aurora borealis, 181

Baer, Francis M., radio operator at Mount Evans, 204, 215, 217, 227, 235, 255, 265, 276, 277, 353

Balloons, pilot, $48,49,50,53,89$, $242,257,259,357,359,365$

Balloons, Sounding, 49, 55

Bangsted, Helge, leader of winter ice-cap expedition, 17, 18, 109, 137, 182, 185-187, 204, 211, 225, $229,241-244,326,329$

Bartlett, Captain Robert A., master of the Morrissey, 3, 12, $15,17,97,99,102,103,104,107$, 130

Bartlett, Will, mate of the Morrissey, 7, 15, 98

Belknap, Ralph L., member of the three Expeditions, 7, 20, 27, 28, $34,56,57,64,73,74,79,86,89$, $102,111,114,118,129,137$, $154,159,162-164,166-168,170$, $172-173,178-180,182,204,213$, $217,219,230,236,237,244$, $245,252,253,255,256,262$, $265,266,269,272,273,276$, 286, 322

Birchall, managing editor of New York Times, 230, 235

Bistrup, Governor Aage, manager at Holstensborg, 17, 18, 33, 38, $64,88,95,179,182,211,216$, $284,301,315,351$
Blue foxes, 169

Burgess batteries, 28, 228

Byrd, Rear Admiral Richard E., 352

Camp on the Maligiakfjord, 21, 117,359

Camp Lloyd, 126, 131, 132, 135, $158,162,183,188,190,203$, $215,225,237,241,243,252$, 278, 280-330, 354

Camp Mortimer E. Cooley, 80, $83-85,91,113,135,161,162,179$

Canoes, Chestnut, 31, 34

Caribou, 242, 243, 260, 261, 282

Caribou Country, exploring in, 237

Carlson, William S., assistant aerologist, 203, 210, 212, 213, 215-219, 230, 237, 238, 255, 262, $265,285,328,330,333,335-342$

Chapin, Mount Roy D., 113

Clicago Tribune, attempt to fly to Europe via Mount Evans, 354,355

Church, Professor J. E., Jr., meteorologist of two Expeditions, 7, $20,27,64,74,82,84,85,97$, $105,111,114,117,118,121,129$, $133,146,147,151,155,159,163$, $166,170,172,178,181-183,186$, $187,195,196,201$

Cramer, Parker D., aviator, 236, $254,262,263,265,266,270$, $271,275-277,279,282,284-$ $287,289,299,307,315,319$, $325,326-328,330,331,338,354$

Cramer, Will, 277

Cryolite of Ivigtut, 316, 324 


\section{INDEX}

Daugaard Jensen, Director Jens, 110, 222, 224, 225, 309

DeGollyer, Dr. E., loaned equipment, 158

DeQuervain, Dr. Alfred, explorer, 41,44

Disko, Danish Government ship, $109-112,117,172,179,181,182$, $186,204,205,207,213,214,225$, $264,266,286,301,303,309,312$, $313,315,347,348-358$

Dodge, Hon. Percival, American minister at Copenhagen, 326

Dunrud, Carl, 4, 11, 13, 15

Emmons, Point, 131, 180

Equipment for sledge trips, 62, $155,156,157,189,244$

Erlanson, Carl O., botanist of Second Expedition, 111, 114, $134,137,146,152,159,167,179$, 181

Esquimos, characteristics of, 66, $242,329,334,358$

Essermann, Bestyrer, 300, 302

Etes, Elmer G., mechanic of Third Expedition, 201, 218, 221, 222, $225,227,229,230,235,237,238$, $241,262,266,267,268,270,271$, $281,286,288$

Evans, Mount, Weather Observatory, $133,136,138$

Fergusson, S. P., aerologist of First Expedition, 7, 14, 27, 55, 88, 98, 99,102

Fiala, Najor Anthony, 130, 156

Fjord-ice, 331

Foehn winds, 46, 83, 91, 147, 151, $192,251,329,337,340,341$

Food, at base, 61, 62

Food on sledge trips, 61, 157

Fredericks, Major L. H., 225, 235

Freuchen, Peter, 109, 326

Friez, Julien P., and Sons, 222, 236

Fulton, tramp-ship, 312, 313, 315, 323

Garden City, L. I., radio station, 38

Geological history of Greenland, 67

Geophone, taken to Greenland, 158
Gertrude Rask, Danish ship, 207, 243, 287

Glacial anticyclone of Greenland, $42,43,47,48,220,357,364,365$

Godthaab, Danish Government vessel, 207

Goettbergsen, Alexander, manager at Kangamiut, 300, 302

Gould, Dr. Larry M., second-incommand of First Expedition, $7,20,27,28,31,34,37,64,70$, $73,74,79,86,99,102,105,244$

"Greater Rockford," Stinson monoplane, 235, 237, 258, 263, $281,285,328,339-340$

Greenland, aspects of, 39

Greenland fjords, winds on, 31; tides in, $32,159,330$

Greenland Glacial anticyclone, 42, $43,47,48,220,357,364,365$

Hans Egede Harbor, 215

Hansen, Captain of Disko, 187

Hansen, Karl D., radio operator of Third Expedition, 342, 354

Hassell, Bert H. J., aviator, 220222, 227, 228, 230, 232, 235-237, $254-256,259,262,263,265,266$, $268,270,273,276-278,284,286$, $289,299,313,315,319,327,330$, $338,354,361-364$

Herz, Fred, mechanic and photographer of Second Expedition, $111,114,118,121,129,133,134$, $141,155,163-168,170,172,173$, $178,180,182,237,301,313$

Hilferty, Dick, 276

Holstensborg, 17, 181, 187, 210, 225,350

Ibsen, Captain, mate of the Fulton, 314

Ice-cap, character of, $39,41,44$, 45,329

Insect pests, 22, 27, 142, 155, 167

Islandsk Falk, Danish government vessel, goes to relief of Morrissey, 87

Ivigtut, $316,319,320,321,322$, 323

Jagt, Nils, President of Cryolite Company, 319-322 


\section{INDEX}

Jensen, Fiskemeester, 121, 124, 136

Kallquist, Clarence R., aerologist of Second Expedition, 111, 117, $118,121,133,134,141,142,155$, $174,179,181,237$

Kangamiut, 292, 296, 299, 300, 301,302

Kelleriman, Maurice, 4, 11, 106

Kellogg, Secretary, 224

Kelsey cataract, 149

Knud Rasmussen ice-arm, 132, $243,249,251,279,280,358$, 362

Koch, Captain J. P., his crossing of Greenland, 41, 44, 173

Koch, Dr. Lauge, Danish polar explorer, 207

Lake Emmons, 85

Lake Herz, water supply of Mount Evans, 134, 238

Lake J. P. Koch, 247, 250, 252, 264,331

Lake Marvin, 162

Lake Melville, 360, 361

Lake Offield, 75

Lake Wise Wood, 253

Landing field for planes, near Camp Lloyd, 225-227, 280

Landscape, types of, in Greenland, 68

Landsvogel Peterssen, 210, 213, 261, 262, 309, 313

Leverett Glacier, 148

Limekiller, Fred, 4

Lockwood outboard motors, use of, 30,159

Maligiakfjord, camp on, in 1926, 21,117

MacMillan, Captain Donald B., 87

Manley, Edward, radio operator on Morrissey, 4

Mátak, 322, 332

Mawson, Sir Douglas, 343

McCormick, Col. Robert R., 354

Möller, Holton, Danish radio operator at Godhavn, 214, 351, 352

Monroe Bay, on Söndre Strömfjord, 245, 251, 252, 330, 331

Morrissey, motor schooner, $3,4,8$, $22,25,87,88,90,92,95,96,102$
Mosquitoes, 22

Mount Evans Observatory, 133 . $136,138,156,181,183,203,210$, $212,215,220,237,241,262,357-$ 365

Mount James B. Ford, 161

Mount Mitchell, 178

Mullins steel boat, 30, 215, 226, $244,245,253,267,271,275$

Nakuak, Eskimo motor-sloop, 212, $213,215,217,264,266,285-287$, 301

Nansen, Dr. Fridtjof, polar explorer, 40, 206

Naylor, William, 220

New York Times, radio station, $227,254,263,266,276,277$

Nielsen, Fiskemeester, 300, 301, 303

Nipisak, motor-sloop, 300-303, 306

Nordenskiöld, Baron Adolf Erik, 40

Nordenskjöld, Dr. Otto, polar explorer, 8, 60, 67, 70

North Pole, not place of extreme cold, 41

North Pole of winds, 43, 47

Northern flight route to Europe, $47,359,360-365$

Northwest River, Hudson Bay post in Labrador, 360, 361

Nyström, Helge, 300

Olsen, David, 19, 32, 33, 65, 90, $91,117,213$

Olsen, Mrs. David, 117, 118, 186

Olsen's Harbor, 120, 122

Oscanyan, Paul C., Jr., radio operator of two expeditions, 7, $20,28,37,38,88,89,102,111$, $131,135,155,181,216,349$

Otto Nordenskjöld Glacier, 79, 80, $82,161,206$

Peary, Rear Admiral Robert E., Discoverer of the North Pole, $12,40,103$

Peary, Robert E., Jr., Engineer of the Morrissey. 5, 12, 15, 20, 95, $96,97,103,106$

Pennsylvania Salt Company, ships to Ivigtut, $264,267,322$ 


\section{INDEX}

Pinney, George H., 354, 355

Point Emmons, 131, 228

Politiken, Copenhagen newspaper, 326

Porsild, Magister Morton, Director of Danish Arctic Station, 19, 266

Potter, David, photographer of Third Expedition, 204, 218, 219, $226,230,237,241,243-245$, 247-249, 251, 255, 259, 260, 262, $264,266,286,293,294,297,303$, 307,315

Ptarmigan, 33, 249, 282, 332

Putnam, David, 5, 106

Putnam, Director George Palmer, $4,13,15,17,18,30,61,88,90$, 93

Pilot balloons, 48, 49, 50, 53, 89, $242,257,259,357,359,365$

Radio Station,

at Garden City, L. I., 38

at landing field, 256

at Maligiakf jord, 28

at Mount Evans, 254, 343-357

of New York Times, 227, 254, $261,263,266,276-278,349$

University of Michigan, R. O.

T. C., 344,354

Rasmussen, Dr. Knud, polar explorer, 17, 25, 93, 101, 109, 110 , Q61, 319, 323

Rasmussen, Governor at Holstensborg, 358

Raven, Dr. Harry C., 4, 17, 106

Reinhartz, John L., 141, 347

Rescue of Hassell, 265, 271-273

Reventlow, Count, Danish Foreign Minister, 224

Rink, Dr. H., 46

Rockford flyers, 220,254

Russell Glacier, 148, 153, 332

"Sandpaper" sledging surface, 190, 191, 332

Sand storms, 196

Sarfanguak, 117, 118, 186, 187

Schlosberg, Lieut. Richard T., U. S. A., 344, 354

Schneider, Leonard R., aerologist of Third Expedition, 204, 215,
$217,219,235-238,255,259,265$, $276,277,354$

Schmeling, Evans S., assistant aerologist at Mount Evans, 354

Scientific Expeditions aboard Disko, 1927, 111

Seals, 135, 137, 160, 188, 197

Shipwreck, of Nakuak, 287, 288

Skinfaxe, tramp steamer, 207-212, $214,262,264$

Söndre Strömfjord, 124, 215, 292, 330

Sonja, Danish whaling vessel, 207 , 209

Stewart, Duncan, Jr., 168, 205, $218,230,237,245,255,265-272$, $281,286,297,299,301,322$

Storehouse ("Radio Shack"), 118, $131,141,188,241,358$

Storms, from Greenland ice-cap, $46,91,97,188,189,192,195$, $198,265,337,340$

Streeter, Daniel W., 4, 11, 19, 20

Sukkertoppen, 301; (old) see Kangamiut

Tents, 63, 64, 130, 131, 154, 184

Tide crack, in ice on fjords, 331

United States Coast and Geodetic Survey, equipment loaned, 156

University Bay, 21, 32

University of Michigan Greenland Expeditions, personnel of, 6 , 111,204

"Untin Bowler" airplane flight, 354,355

Walrus, Danish motor-schooner, $88,113,114,119-122,124,182$, $183,210,211-214,225,229,230$

Watson river, $159,160,179,190$, 196,202

Wilkins, Sir Hubert, 206

Winds, Foehn, 46, 83, 91, 147, 151, $192,251,329,337,340,341$

Winds, from the ice-cap, 39, 138, $141,142,151,186,235,251,280$, 337,341

Winds, North Pole of, 43, 47

Wreck of Nakuak, 287, 288

Young, "Art.," 4, 11, 100 





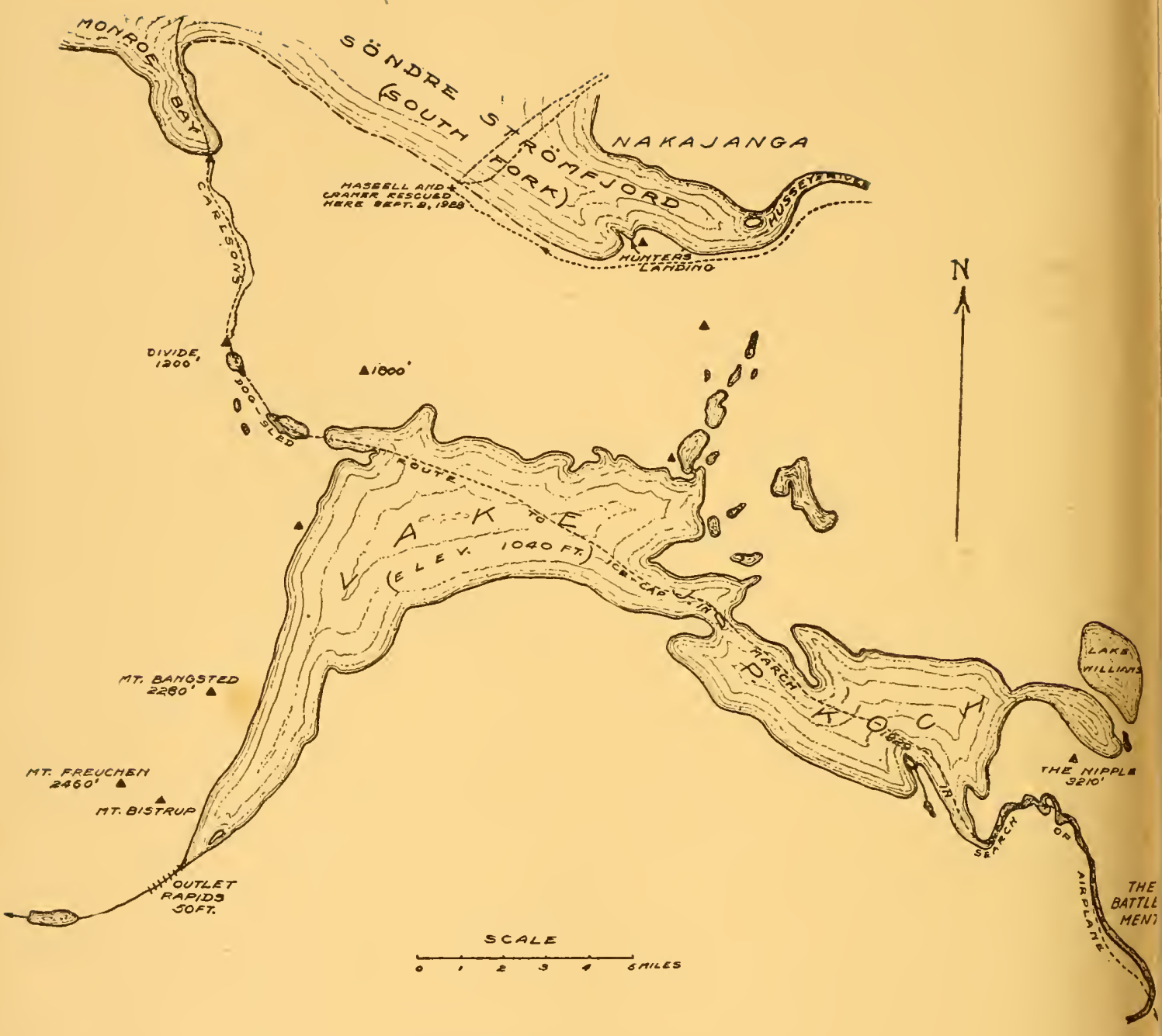

MAP TO SHOW
EXPLORATIONS SOUTH SÖNDRE OFTHE $\begin{gathered}\text { STROMINUORD } \\ \text { IOEO }\end{gathered}$ WESTERH AREA OT HOQBS, EASTERN or POTTER. 


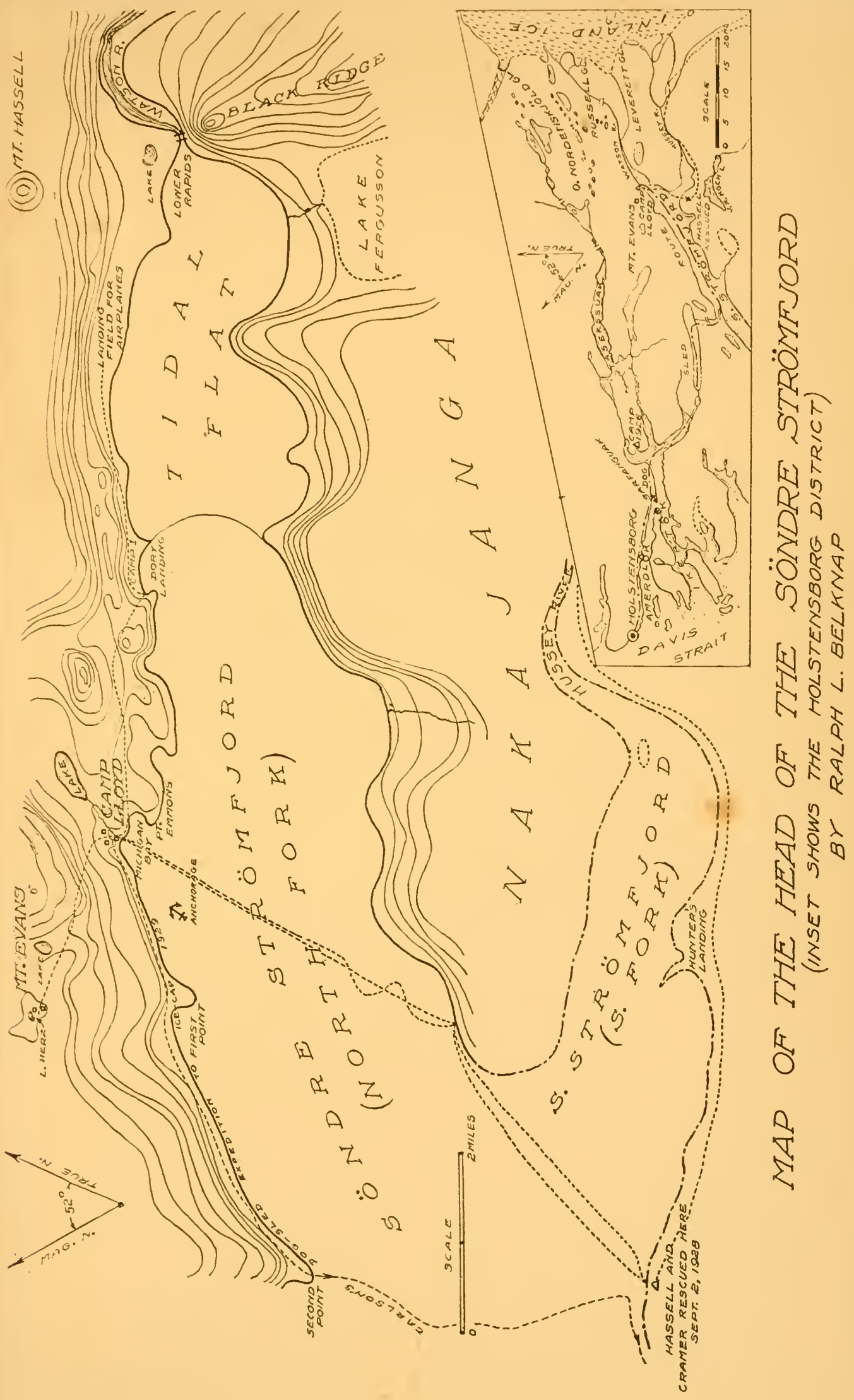


